\title{
Bedrock Geologic Map of the Seward Peninsula, Alaska, and Accompanying Conodont Data
}

By Alison B. Till, Julie A. Dumoulin, Melanie B. Werdon, and Heather A. Bleick

Pamphlet to accompany

Scientific Investigations Map 3131

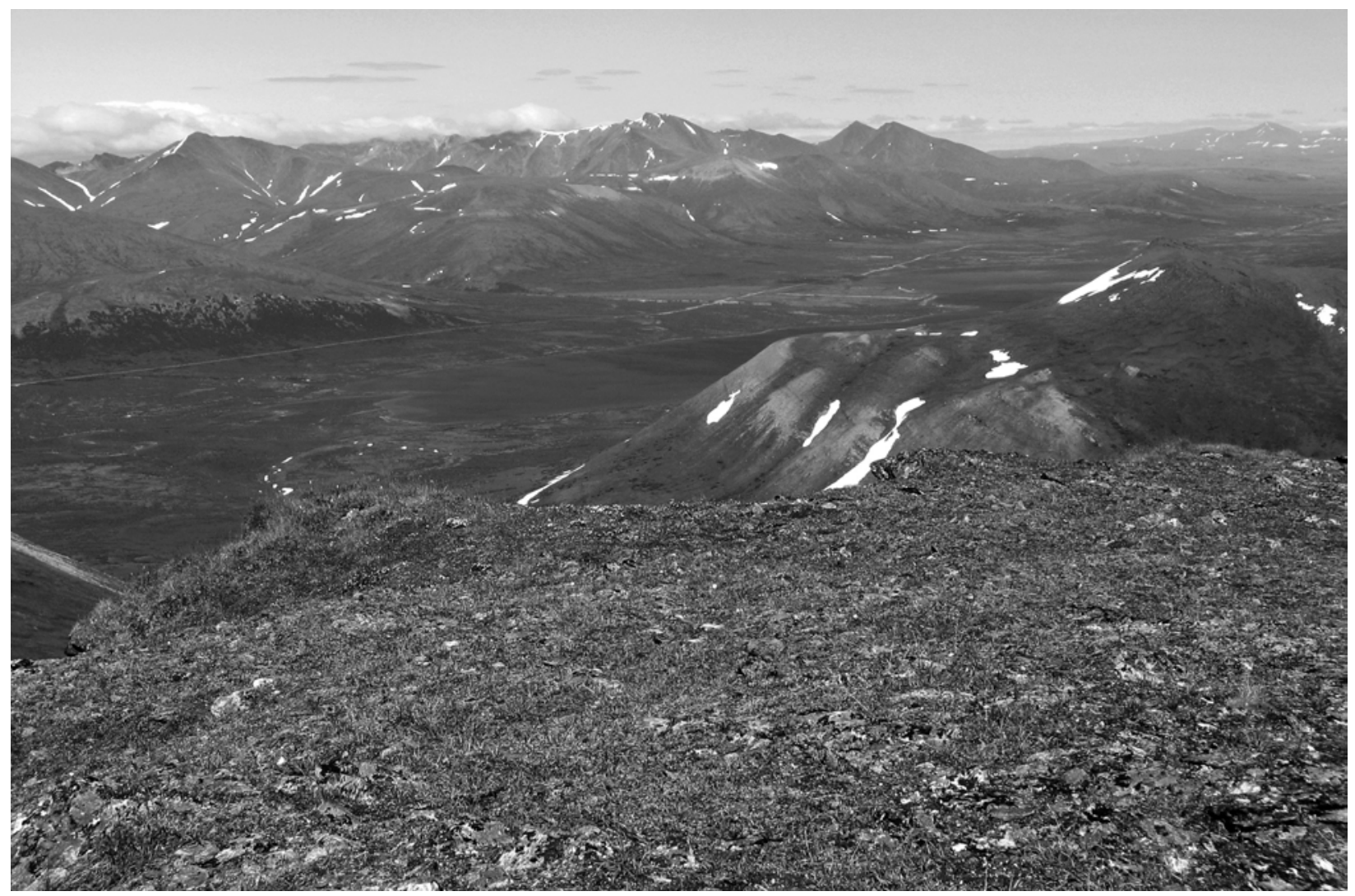

View of Salmon Lake and the eastern Kigluaik Mountains, central Seward Peninsula

U.S. Department of the Interior

U.S. Geological Survey 



\section{Contents}

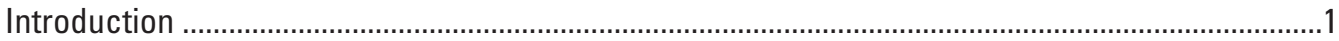

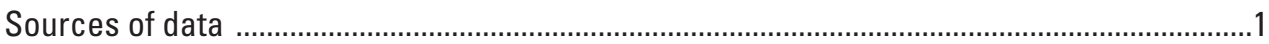

Components of the map and accompanying materials ..........................................................1

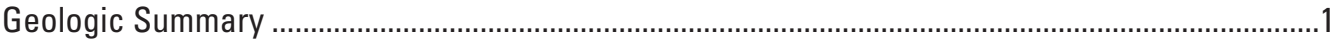

Major geologic components ............................................................................................

York terrane ....................................................................................................................2

Grantley Harbor Fault Zone and contact between the York terrane and the Nome

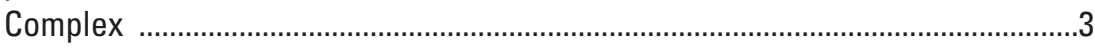

Nome Complex .................................................................................................................

High-grade metamorphic and associated igneous rocks ................................................

Yukon-Koyukuk basin, Angayucham terrane, and the Kugruk Fault Zone .......................

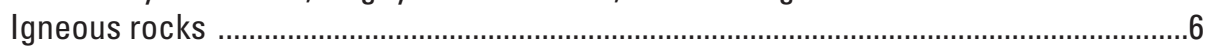

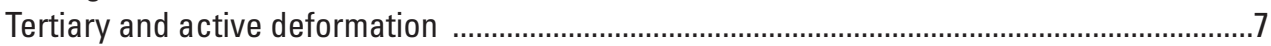

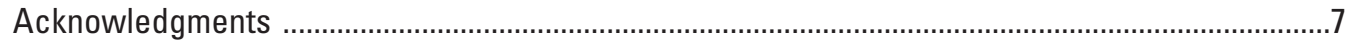

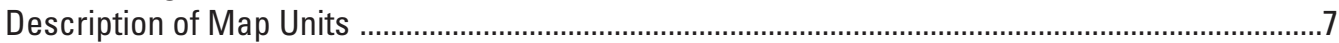

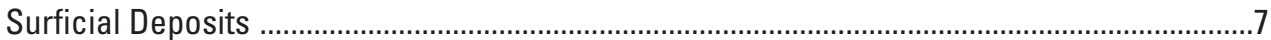

Mesozoic and Cenozoic Igneous Rocks ..........................................................................

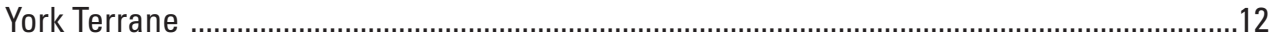

York Mountains Succession ...........................................................................................12

Units with Uncertain Affinities ......................................................................................15

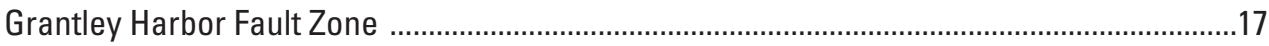

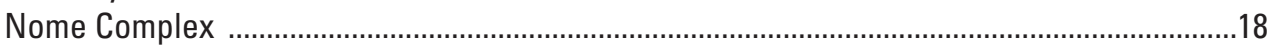

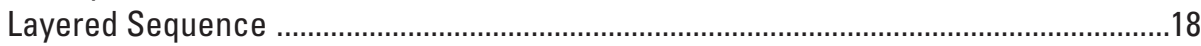

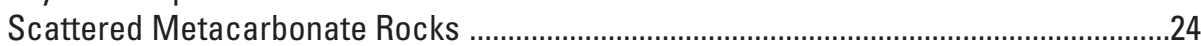

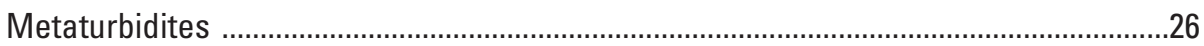

High-Grade Metamorphic and Associated Igneous Rocks ..................................................27

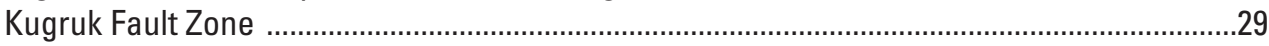

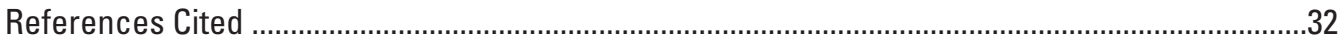

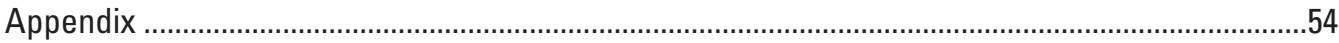

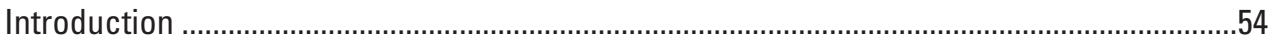

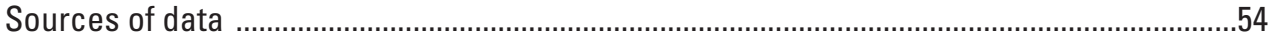

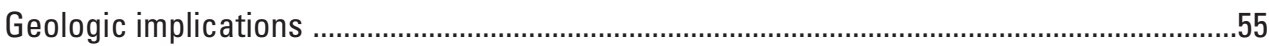

Nome Complex and Kugruk Fault Zone .....................................................................55

York terrane and Grantley Harbor Fault Zone ..............................................................55

\section{Figures}

1. Map of northern Alaska showing major geographic areas, geological provinces, and the outline of the map area .

2. Map of the Seward Peninsula, Alaska showing locations and names of Quaternary, Tertiary, and Cretaceous igneous rocks. Cenozoic volcanic rocks, pale yellow; Late Cretaceous tin-bearing granites, orange; compositionally diverse Early and Late Cretaceous rocks, red map sheet 2

\section{Tables}

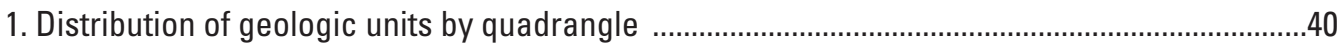

2. Selected K-Ar, ${ }^{40} \mathrm{Ar} / 39 \mathrm{Ar}$ and $\mathrm{Rb}-\mathrm{Sr}$ age determinations ...................................................42

3. Selected U-Pb zircon analyses ...................................................................................

A-1. Conodont data from the Seward Penninsula .......................................................................58

A-2. Temperature ranges for Color Alteration Indices (CAls) of conodonts .................................75

\section{Sheets}

1. Preliminary bedrock geologic map of the Seward Peninsula, Alaska

2. Tectonic, metamorphic, geochronologic, and geographic data for the Seward Peninsula, Alaska 



\section{Introduction}

This 1:500,000-scale geologic map depicts the bedrock geology of Seward Peninsula, western Alaska, on the North American side of the Bering Strait. The map encompasses all of the Teller, Nome, Solomon, and Bendeleben 1:250,000-scale quadrangles, and parts of the Shishmaref, Kotzebue, Candle, and Norton Bay 1:250,000-scale quadrangles (sh. 1; sh. 2).

Rolling, tundra-covered hills cover most of Seward Peninsula; trees and shrubs are present only in limited areas in the southern and eastern parts of the peninsula. Broad lowlands underlie large areas in central and northern Seward Peninsula. Part of the central area and large areas in northernmost and easternmost Seward Peninsula are an extensive, unvegetated lava field. Four glacially carved mountain ranges, the York, Kigluaik, Bendeleben, and Darby Mountains, reach heights of 1,000$1,300 \mathrm{~m}$ (sh. 2); the highest point on the Peninsula, Mount Osborn, is in the Kigluaik Mountains. The York Mountains of western Seward Peninsula and hills adjacent to them on the east are underlain by bare, unvegetated carbonate rocks.

The map area covers $74,000 \mathrm{~km}^{2}$, an area slightly larger than West Virginia or Ireland.

\section{Sources of Data}

This geologic map is a compilation of published and unpublished geologic mapping and information derived from other published and unpublished sources. Published geologic maps at scales of 1:250,000, 1:63,360, and 1:50,000 were major sources and range in publication date from 1972 to 2005. More detailed studies, including theses, papers, and unpublished mapping, represent work done between 1980 and 2008.

The amount of geologic detail available varies significantly across the area of the map, because of variations both in degree of study and in quality of bedrock exposure. Bedrock exposure, outside of the mountain ranges, is generally poor in the northern peninsula, and better in southern parts of the peninsula. The most detailed geologic mapping on the peninsula has been concentrated in the York and Kigluaik Mountains, and the central Solomon quadrangle. The distribution of some metamorphic indicator minerals and conodont color alteration index (CAI) values presented on sheet 2 is limited by quality of exposure and amount of study in a given area.

\section{Components of the Map and Accompanying Materials}

The geologic map and related supplemental information are presented in two oversized sheets, this text, three tables, and an appendix. The appendix includes an explanatory text and two tables.

The geologic map, Correlation of Map Units, List of Map Units, and sources of data are shown on sheet 1 . The geographic names referenced in the text, metamorphic/tectonic subdivisions of the map area, and selected metamorphic and thermal history data are shown on sheet 2. Metamorphic and thermal history data are largely from the collections of the authors, but include all available information from government, industry, and academic sources.

Table 1 shows the distribution of the map units on the nine 1:250,000-scale quadrangle maps of the map area, and augments geographic information provided in the Description of Map Units.

Geochronologic data in tables 2 and 3 were compiled from the literature; a few unpublished ages were included. Results that were shown by researchers to be analytically sound and geologically meaningful have been included in the tables, while less sound results (for example, ${ }^{40} \mathrm{Ar} /{ }^{39} \mathrm{Ar}$ age spectra lacking plateaus, K-Ar analyses with poor radiogenic yield) have been excluded. In a few cases, results that did not meet these criteria have been included; statements in the "comments" column of the table indicate when and why this was done. All ages mentioned in this report are listed in the tables.

The appendix includes discussion of sources and distribution of conodont data and geologic implications of the data. Table A-1 lists the conodont data by 1:250,000-scale quadrangle. Table A-2 summarizes the temperature ranges thought to correspond to color-alteration index (CAI) values of conodonts.

Geologic time-scale age boundaries used are those of Gradstein and Ogg (2005).

\section{Geologic Summary}

\section{Major Geologic Components}

Most of Seward Peninsula is underlain by rocks that were part of a Late Proterozoic to early Paleozoic continental margin; remnants of that margin are also present in the Brooks Range. Rocks of the Chukotsk Peninsula, $85 \mathrm{~km}$ west of the Seward Peninsula, across Bering Strait (sh.1, 2), probably were part of the same continental margin as well (Dumoulin and others, 2002). The extensive high-pressure metamorphic rocks exposed in central Seward Peninsula (Nome Complex), the southern Brooks Range, and the Ruby geanticline are thought to record subduction of that continental margin during the Jurassic (Patton and Box, 1989; Christiansen and Snee, 1994; Roeske and others, 1995; Gottschalk and Snee, 1998) (fig. 1).

During the Early Cretaceous, contractional deformation ceased within the subduction zone, moved into the subjacent continental crust, and propagated to shallower levels. As a result, the continental margin was involved in a mountainbuilding episode, which involved thickening of the continental crust and movement of thrust sheets northward. We refer to this post-subduction contractional deformation of continental crust as the Brooks Range orogeny. Some exhumation of the Nome Complex blueschists by thrust faulting may have been part of this episode. Rocks in the York Mountains of Seward Peninsula likely experienced thrust faulting and shallow burial at this time, based on thermal indices (conodont color alteration indices; table A-2) from carbonate rocks and outcrop-scale structures in siliciclastic rocks. 


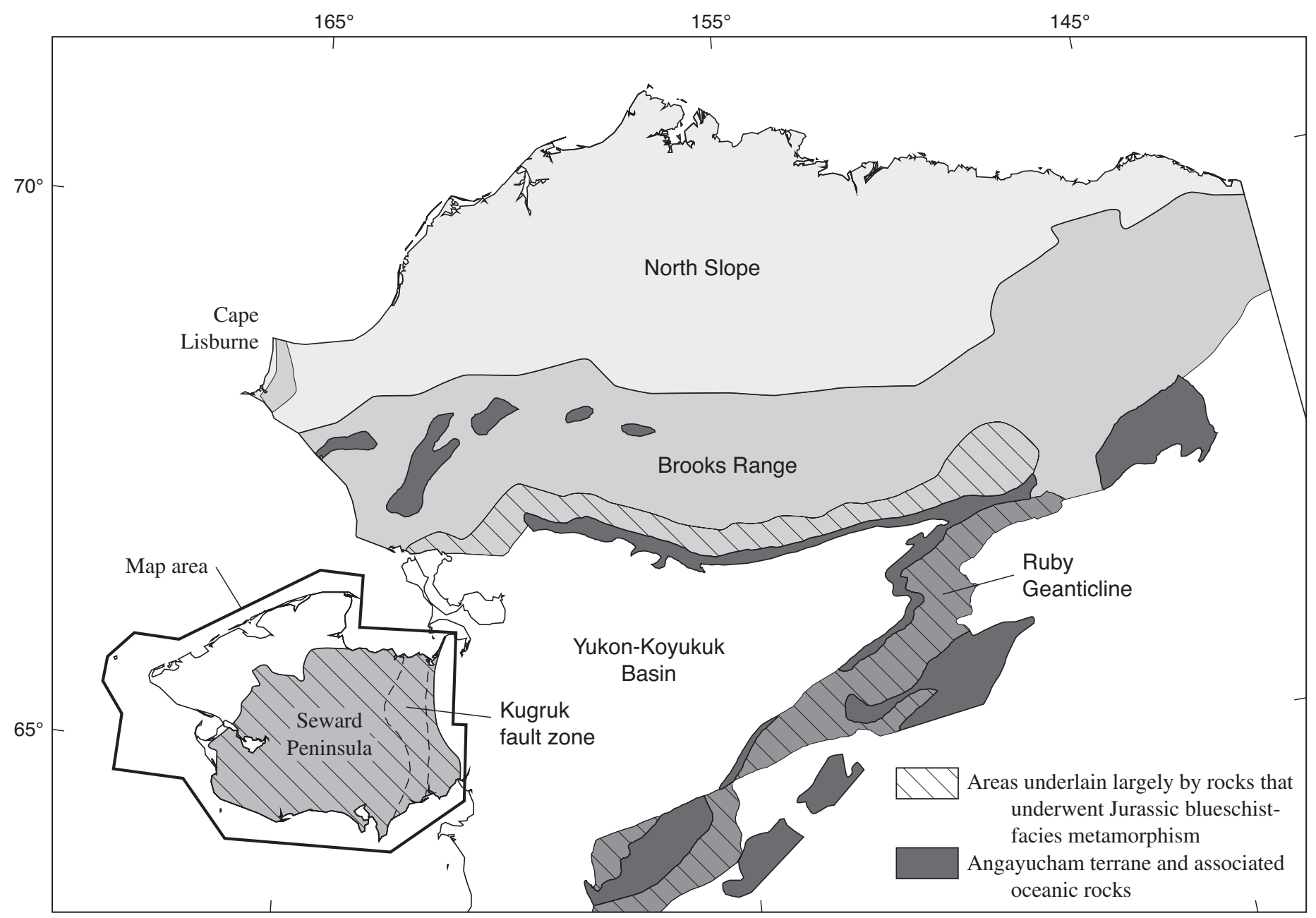

Figure 1. Map of northern Alaska showing major geographic area, geological provinces, and the outline of the map area.

Metamorphic fabrics in the Nome Complex have been related to subduction zone deformational processes (Thurston, 1985; Patrick, 1988) and extensional collapse of the Brooks Range orogen after the mountain building and crustal thickening episode (Hannula and others, 1995; Amato and others, 2002). ${ }^{40} \mathrm{Ar} /{ }^{39} \mathrm{Ar}$ and fission-track data indicate that significant cooling of the high-pressure metamorphic rocks now exposed on Seward Peninsula occurred in the period 120-70 Ma (Hannula and McWilliams, 1995; Dumitru and others, 1995); extensional deformation is thought to have occurred during that time span.

Amphibolite to granulite facies metamorphism overprinted the Nome Complex and other rocks during the mid-Cretaceous; at about the same time, a protracted period of magmatism began on Seward Peninsula and lasted until the end of the Cretaceous (fig. 2, on sh. 2). At least one suite of plutonic rocks formed in an island arc setting (Amato and Wright, 1997). During the Cenozoic, normal faulting created small mountain ranges and adjacent sedimentary basins, and mafic volcanic rocks accumulated in the central and northern parts of the peninsula.

In this text the term "metabasite" refers to metamorphosed mafic rocks of any nature, including originally intrusive and extrusive varieties.
Based on lithology, age, tectonic affinity, and metamorphic history, rocks of Seward Peninsula are divided into several tectonic subdivisions, illustrated on sheet 2 .

\section{York Terrane}

Rocks of western Seward Peninsula are mostly lower Paleozoic and possibly older carbonate and siliciclastic rocks that retain primary sedimentary features except where they occur near granitic intrusions or where they are mica rich. We divide the York terrane into two parts: the "York Mountains succession", a relatively well-studied stratigraphic sequence found mainly in the central York Mountains, and "Units of uncertain affinities", a group of relatively poorly understood rocks (sh. 1).

Thermal indicators, based on conodont color alteration index (CAI) values, show that the York terrane contains several provinces with different thermal histories, and therefore, different burial and tectonic histories (sh. 2, appendix 1). Some York terrane rocks are unmetamorphosed (most of the York Mountains succession), and some may have reached low greenschist facies conditions (Units with uncertain affinities). Siliciclastic rocks in units with higher thermal indices (units $\mathrm{OPt}, \mathrm{OPI}$ ) and a related unit (OPp) display open folds with a sub-horizontal 
axial plane cleavage; finer-grained rocks are slates or phyllites and are crenulated. These units probably experienced burial and deformation during the Brooks Range orogeny. Carbonate rocks with lower thermal indices, in the central York Mountains, were much more shallowly buried (sh. 2). Structures that separate different thermal provinces have yet to be delineated, but are important for defining the deformation history of the York terrane.

Carbonate strata of the York terrane correlate well with carbonate successions in three regions: the Brooks Range (northeast of the Seward Peninsula), the Farewell terrane of interior Alaska (southeast of Seward Peninsula), and the peri-Siberian terranes of northeastern Russia (Dumoulin and Harris, 1994; Dumoulin and others, 2002). Lithofacies and biofacies of York terrane carbonate rocks are especially similar to those of coeval strata in the western Brooks Range (Baird Mountains) and the Farewell terrane. Rocks in all three regions contain a distinctive biota characterized by both Siberian and Laurentian (North American) endemic forms, including many identical species. Detailed lithologic similarities between the three successions are also numerous (Dumoulin and others, 2002).

\section{Grantley Harbor Fault Zone and Contact Between the York Terrane and the Nome Complex}

Several lenses of low-grade metasedimentary rocks, probably fault bounded, sit on the structural contact between the York terrane and the Nome Group. This zone is distinguished on the map because the rocks are more penetratively deformed than similar lithologies in the York terrane, and less penetratively deformed than similar lithologies in the Nome Complex. Hannula and others (1995) considered these rocks part of a structurally coherent section that decreases in metamorphic grade from the Kigluaik Mountains northwest to the coast. However, there is a metamorphic discontinuity within the section. Metamorphic grade of the Nome Complex does decrease from the Kigluaik Mountains to the northwest; metabasites nearer the Kigluaik Mountains are blue amphibole-bearing, and those farther away contain lower grade pumpellyite-actinolite assemblages (Hannula and others, 1995) (see unit Pznp). However, a sliver of Nome Complex rocks that contain lawsonite and glaucophane pseudomorphs sits between the pumpellyiteactinolite grade rocks of unit Pznp and the subgreenschist facies unit of the Grantley Harbor Fault Zone (sh. 2). The sliver of schists that contain glaucophane and lawsonite pseudomorphs must have been structurally imbricated with the adjacent rocks.

Faults within the Grantley Harbor Fault Zone are part of the regionally important structural contact between the Nome Complex and the York terrane. The contact was interpreted as a thrust fault by Till and Dumoulin (1994), based on possible correlation with east-vergent structures on the Lisburne Peninsula, western Brooks Range (Patton and Tailleur, 1977; Moore and others, 2002). However, models for mid-Cretaceous crustal extension (Miller and Hudson, 1991) and evidence for extensional faulting within the York terrane (Toro and others, 2006) are consistent with an extensional detachment between the York terrane and the Nome Complex. The contact between the York terrane and the Nome Complex, which is very poorly exposed, may have been a thrust fault during the contractional mountainbuilding phase of the Brooks Range orogeny, and been reactivated multiple times as a thrust and(or) extensional surface.

\section{Nome Complex}

The low, rolling hills of central and eastern Seward Peninsula are underlain by lithologically varied rocks that have well-developed blueschist and greenschist metamorphic fabrics. These rocks underlie most of the peninsula, including the highly productive gold districts that have attracted geologists' attentions since the 1899 Nome gold rush.

The metamorphic rocks consist of several thick mappable lithologic sequences, scattered carbonate rocks with an uncertain relation to those sequences, and small bodies of orthogneiss. Mesozoic ductile and penetrative deformation largely obliterated primary sedimentary and igneous textures. Sparse conodont and other fossil collections and zircon ages from orthogneisses provide limited age control, and were interpreted to indicate Neoproterozoic and Paleozoic protolith ages for the unit overall (Till and others, 1986).

In 1900, U.S. Geological Survey geologists created the first topographic and geologic maps of the newly discovered Nome gold fields. They first applied the name "Nome series" to the lithologically complex metamorphic rocks that underlie the placer deposits of southern Seward Peninsula (Brooks and others, 1901). Initially, the approach to differentiation of units was stratigraphic, and was based upon apparent superposition of lithologic units and a small number of megafossil collections. Within a few years, as additional megafossil ages conflicted with the perceived relations within the series, the name "Nome group" was proposed (Collier and others, 1908). In proposing the change, Collier and others (1908) noted that the unit was not a stratigraphic one, but rather was heterogeneous and metamorphic; no type section was proposed, and lithologic descriptions were very simple. In modern stratigraphic nomenclature the term "group" is for a set of related lithostratigraphic units; the term "complex" is for highly deformed rocks such as those exposed in central Seward Peninsula (North American Commission of Stratigraphic Nomenclature, 2005).

We include all rocks on Seward Peninsula that exhibit a common set of structural and (or) metamorphic features, likely formed in the same deformational event, in the Nome Complex. Although the bulk of the Nome Complex shows evidence of high-pressure metamorphism, rocks along the eastern, western, and northern boundaries of the complex crystallized at slightly different peak metamorphic conditions (sh. 2). In these cases, similarities in structural fabric elements and lithologic characteristics suggest that they were part of the same metamorphic event, and are therefore included in the complex. A number of the lithologies in central Seward Peninsula do not produce mineral assemblages diagnostic of metamorphic grade; in those cases, a structural style consistent with lithologies that do contain high-pressure minerals is used for inclusion in the complex. A few lithologies, such as fine-grained dolostones, do not manifest the structures common in most of the Nome Complex, and are exposed in isolated outcrops. Where available, color 
alteration index values (CAIs) of conodonts that are consistent with the conditions of high-pressure metamorphism were used to include these rocks.

We divide the Nome Complex into three parts (sh. 1). The designated "Layered sequence" consists of mappable lithologic units that occur in a consistent, layer-cake structural relation to one another over much of central Seward Peninsula. The designated "Scattered metacarbonate rocks" consists of volumetrically minor dolostones and marbles that are widely distributed. Units that are exposed only on the north and southeast coasts of the peninsula (DObm, D€bm, D€ks) are included in the designated "Metaturbidites".

The character of the lithologies in the Nome Complex is consistent with formation on a continental shelf and slope. Some carbonate rocks (units $€ d$, Od, Sd, Ddm of Scattered metacarbonate rocks) contain sedimentary features, megafauna, and (or) microfauna typical of shallow water conditions. Other rocks show features that indicate they formed in slope and basinal environments (Metaturbidites units DObm, D€bm). Metasedimentary rocks that formed from combined carbonate, siliciclastic, and graphitic components are common; metasedimentary rocks composed of intermixed mafic, carbonate, and siliciclastic components are also widespread. Chemical characteristics of the mafic rocks in the Nome Complex indicate that they formed during rifting of a continental margin (Werdon and others, 2005a; Ayuso and Till, 2007).

The age of the Nome Complex protolith is known from microfossils, megafossils, U-Pb zircon analyses, and detrital zircon analyses. Cambrian, Ordovician, Silurian, and Devonian fossils were collected from carbonate rocks (Till and others, 1986). Small, Late Proterozoic orthogneiss bodies have been identified (Patrick and McClelland, 1995; Amato and Wright, 1998; Till and others, 2006), as well as several Middle Devonian metagranitic bodies (Till and others, 2006; Gottlieb and Amato, 2008; Amato and others, 2009). Detrital zircon analyses reveal that very little of the protolith of the complex was deposited before $600 \mathrm{Ma}$, and some metamorphosed siliciclastic rocks are likely Devonian or younger (Amato and others, 2003a; Amato, 2004; Till and others, 2006, 2007). Mafic rocks that formed during rifting of the continental margin have not been directly dated in the Nome Complex, but are thought to be Ordovician (see description of unit Ocs).

Penetrative ductile deformation and recrystallization of the sequence make geologic mapping and identification of the nature and precise age of the protolith extremely difficult. The presence of mafic boudins that contain blueschist-facies minerals in the Nome Complex was first noted by Sainsbury and others (1970); Thurston (1985) documented blueschist-facies minerals in a variety of lithologies, showing that high pressure/ low temperature metamorphism affected the entire Nome Complex. The Nome Complex, therefore, is a metamorphic complex initially formed during subduction of a continental margin. This indicates that lithologic units within the Nome Complex were removed from the surface of the subducting continental crust - but not necessarily in a way that retains their original stratigraphic relations. Based on available detrital zircon data, the structurally lowest parts of the Nome Complex are the youngest parts of its protolith (Till and others, 2006).
The metamorphic history of the Nome Complex is imperfectly known, especially its history after peak high-pressure/ low-temperature metamorphism. As is the case with many blueschist-facies metamorphic terranes, many lithologies in the Nome Complex do not contain mineral assemblages diagnostic of metamorphic grade. The same mineral assemblages may form, for example, at both high pressure (blueschist-facies) and low pressure (greenschist-facies) conditions. Further, greenschist- and blueschist-facies mineral assemblages can form at the same conditions in mafic rocks of slightly different compositions (Evans, 1990). Finally, in the Nome Complex greenschist-facies assemblages do overprint blueschist-facies minerals locally, but establishing the relation of greenschist assemblages to deformational events and the age of those events are challenging. Distinguishing the metamorphic history of the Nome Complex - especially the history after peak high-pressure metamorphism — has shown to be particularly difficult.

Based on thermobarometry and petrography, the metamorphic pressure-temperature path of the Nome Complex traversed the lawsonite-stable part of blueschist facies and reached peak pressure in the epidote-stable part of blueschist facies/eclogite facies (Forbes and others, 1984; Thurston, 1985). Conditions of peak pressure were estimated at $460{ }^{\circ} \mathrm{C}, 12 \mathrm{~kb}$ (Patrick and Evans, 1989). Temperature peaked during exhumation in albiteepidote-amphibolite-facies. This pressure-temperature path is identical to that documented in the Schist belt in the southern Brooks Range (Till and others, 1988; Gottschalk, 1998) and is similar to that in the Ruby geanticline (Roeske and others, 1995) (fig. 1); the Nome Complex, Schist belt, and schists in the core of the Ruby geanticline probably formed during the same subduction episode.

Geochronologic studies to date have not clearly documented the timing of the high-pressure event on Seward Peninsula. Although $\mathrm{Rb}-\mathrm{Sr}$ and $\mathrm{K}-\mathrm{Ar}$ ages indicated a Jurassic age of metamorphism (Armstrong and others, 1986), ${ }^{40} \mathrm{Ar} /{ }^{39} \mathrm{Ar}$ plateau ages from white mica in the Nome Complex typically span the ages from 109 to $125 \mathrm{Ma}$ (table 2); these ages are thought to represent minimum ages for blueschist-facies metamorphism (Hannula and McWilliams, 1995). The Rb-Sr ages are from essentially 2-point isochrons; therefore, their value is also limited. Sodic-calcic amphibole from a vein thought to have formed during decompression and heating of the Nome Complex yielded a ${ }^{40} \mathrm{Ar} /{ }^{39} \mathrm{Ar}$ plateau age of $138.6 \pm 1.0 \mathrm{Ma}$ (Layer and Newberry, 2005; table 2); this age approximates the timing of peak temperature for the Nome Complex, and is a minimum age for peak pressure. White mica ${ }^{40} \mathrm{Ar} /{ }^{39} \mathrm{Ar}$ ages from metamorphically correlative rocks in the Ruby geanticline place a minimum age of $144 \mathrm{Ma}$ on the blueschist-facies event (Roeske and others, 1995), and blueschist-facies rocks of the southern Brooks Range are thought to have reached peak pressure during the Middle Jurassic (Christiansen and Snee, 1994; Gottschalk and Snee, 1998). Based on the age of the vein-filling sodiccalcic amphibole and correlative nature of high-pressure/lowtemperature metamorphic events in the Brooks Range and Ruby geanticline, we believe that the Nome Complex reached peak pressure during the Jurassic.

The degree to which the dominant structural fabric in the Nome Complex is a product of exhumation processes, rather 
than subduction processes, is a matter of some controversy. Thurston (1985) and Patrick (1988) suggested that the parallelism of glaucophane and pseudomorphs after glaucophane with the dominant fabric indicates that the fabric was formed during high-pressure metamorphism. Miller and Hudson (1991) postulated that Seward Peninsula was part of a vast region that underwent crustal extension in the mid-Cretaceous in response to crustal thickening during the Brooks Range orogenic episode. Based on structural and metamorphic analysis, Hannula and others (1995) contended that the dominant fabric in the Nome Complex was related to the extensional episode, and the blueschist fabric was largely overprinted. Because many of the lithologies in the Nome Complex display the same metamorphic assemblages at blueschist or greenschist facies, this is a challenging problem to unravel.

Sheet 2 shows subdivisions of the Nome Complex that highlight small differences in metamorphic and(or) deformational history. In central Seward Peninsula, the greater part of the Nome Complex displays consistent metamorphic and deformational features. These rocks possess a penetrative fabric formed in a ductile setting and, in appropriate lithologies, contain minerals diagnostic of blueschist-facies conditions. Glaucophane and fine intergrowths of chlorite and albite that pseudomorph glaucophane are widespread in mafic, pelitic, and calcareous lithologies. One metabasite contains the eclogitefacies diagnostic minerals jadeitic pyroxene (omphacite) and garnet (Nome Complex-central; sh. 2). Exposures of the Nome Complex margins (west, north, and east) show slight variations in deformational and structural style. Descriptions of these variations are on sheet 2 and in the Description of Map Units.

\section{High-grade Metamorphic and Associated Igneous rocks}

Amphibolite and granulite-facies metamorphic rocks are exposed in the Kigluaik, Bendeleben, and Darby Mountains and in a small area north of the Oonatut Granite Complex in the northwestern Bendeleben quadrangle (fig. 2, on sh. 2). These high-grade metamorphic rocks formed during the Cretaceous and have no identified direct counterparts in the Brooks Range, although potentially metamorphically correlative rocks are known in the Ruby geanticline (Roeske and others, 1995). On Seward Peninsula, some lithologic units in the high-grade metamorphic rocks are identical to lithologic units recognized in the Nome Complex (Till and others, 1986, Till and Dumoulin, 1994), and other lithologies are not known in the Nome Complex (for example, ultramafic and associated rocks that are exposed at the core of the Kigluaik Mountains). The oldest dated rock on Seward Peninsula (870 Ma), a foliated metarhyolite, is exposed in the southwestern Bendeleben Mountains (Gottlieb and Amato, 2007; Amato and others, 2009). No rocks of that age have been identified in the Nome Complex.

High-grade metamorphic assemblages record a polyfacial metamorphic history that has not been studied in detail. In some areas, high-grade metamorphic assemblages demonstrably overprint blueschist and greenschist-facies assemblages that formed during metamorphism of the Nome Complex (Thurston,
1985; Till and others, 1986; Hannula and others, 1995). Kyanite is present in pelitic rocks in all three mountain ranges; kyanitebearing assemblages are typically overprinted by sillimanitebearing assemblages, and therefore represent an early part of the metamorphic history. Evidence for decompression is recorded in some of the high-grade metamorphic rocks. In rare lithologies high in aluminum and iron, earlier, higher pressure assemblages (orthoamphibole plus aluminosilicate) are overprinted by lower pressure assemblages (cordierite plus staurolite or garnet) (sh. 2).

The metamorphic history of rocks in the two east-west trending ranges (Kigluaik, Bendeleben) is broadly similar. Metamorphic grade in the Kigluaik Mountains increases towards the core of an antiform, or dome, defined by foliation and gneissic layering. Two-pyroxene gneisses, definitive of granulite facies, are present in the core of the antiform near Mount Osborn (Till, 1980; Lieberman, 1988; sh. 2). Peak metamorphic grade in the Kigluaik Mountains is thought to have occurred at about $91 \mathrm{Ma}$, immediately before or coincident with intrusion of the Kiglauik pluton (Amato and others, 1994; Amato and Wright, 1998). Metamorphic isograds in the Kigluaik Mountains are closely spaced, a feature likely related to exhumation processes (Patrick and Lieberman, 1988; Miller and others, 1992; Calvert and others, 1999). In the central Bendeleben Mountains, foliation is also domed (Gottlieb and Amato, 2008). However, metamorphic zonation is less well known and apparently more complex than in the Kigluaik Mountains; the timing and conditions of peak metamorphism have yet to be directly documented. Also the relations of the two plutons in the Bendeleben Mountains to high-grade metamorphism is unknown; part of the Bendeleben pluton is older (104 Ma) and the Pargon is younger (86 Ma) than the Kigluaik pluton (Gottlieb and Amato, 2008). Rapid cooling (to $<200{ }^{\circ} \mathrm{C}$ ) of the Kigluaik gneisses and schists occurred between 87 and $78 \mathrm{Ma}$ (Calvert and others, 1999). U-Pb ages on zircon rims in cordierite schist and on zircon grains in igneous rocks in the Bendeleben Mountains seem to indicate that decompression occurred at about 88 to $85 \mathrm{Ma}$ (Gottlieb and Amato, 2008); biotite and monazite cooling ages from the Bendeleben Mountains range from 87 to $81 \mathrm{Ma}$ (Turner and Swanson, 1981; Gottlieb and Amato, 2007).

The high-grade metamorphic rocks of the Kigluaik and Bendeleben Mountains are structurally coherent and domed, whereas distribution of high-grade metamorphic rocks in the north-south oriented Darby Mountains is more complex. Metamorphic grade increases along the axis of the Darby range from north to south, culminating in the area around Mount Arathlatuluk (sh. 2). In the northern part of the range, Nome Complex rocks are present and have biotite-grade metamorphic overprints. The central part of the range contains staurolite- and kyanite-bearing assemblages; kyanite may be relict from an early metamorphic event. At Mount Arathlatuluk, small, biotite-granite stocks occur with granulite-facies ( 2 pyroxene) metamorphic assemblages (sh. 2); sillimanite is common. Zircon from a granite stock yielded a U-Pb age of $108 \mathrm{Ma}$, an age that broadly approximates the time of peak temperature (R. Friedman, written commun., 2009). The low-grade rocks in the northern Darby Mountains are juxtaposed with a slice of high-grade metamorphic rocks (on the west flank of the mountains) along a high- 
angle reverse fault; the age of the fault is not known. At the time of intrusion of the Darby pluton, the metamorphic rocks were in shallow $(<5 \mathrm{~kb})$ crustal settings; the Darby pluton has andalusite in its contact zone (sh. 2). The Darby pluton yielded two U-Pb zircon crystallization ages of $100 \mathrm{Ma}$ (Amato, written commun., 2008; R. Friedman, written commun., 2009).

Although the three mountain ranges (Kigluaik, Bendeleben, and Darby Mountains) appear to describe a small orocline, the ranges do not have the same exhumation history. The apparent orocline is due to the intersection of structures of different ages. Biotite cooling ages from the Kigluaik and Bendeleben Mountains range from 87 to $81 \mathrm{Ma}$; biotite cooling ages are older in the Darby Mountains, ranging from 102 to $90 \mathrm{Ma}$. Apatite fission-track analysis indicates that the Kigluaik and (by inference) Bendeleben Mountains were cooled and uplifted during the Tertiary (Eocene-Oligocene; Dumitru and others, 1995), whereas rocks in the northern Darby Mountains were at the surface during the early Eocene, as the Darby pluton (unit $\mathrm{Kd}$ ) is basement to a small sedimentary basin of early Eocene age (Dickinson and others, 1987).

\section{Yukon-Koyukuk Basin, Angayucham Terrane, and the Kugruk Fault Zone}

The Yukon-Koyukuk basin sits along the eastern side of Seward Peninsula and contains Early Cretaceous subductionrelated volcanic rocks and related marine sedimentary rocks. The basin is flanked on three sides by terranes with continental affinity: Seward Peninsula on the west, Brooks Range on the north, and Ruby geanticline on the east (fig. 1). The basin is bordered by marine to non-marine conglomerates that are younger than the marine volcanic and sedimentary rocks within the basin and were derived from adjacent continental rocks (Patton and Box, 1989).

Along its eastern and northern boundaries, the YukonKoyukuk basin is separated from flanking continental rocks by a belt of mafic and ultramafic rocks and minor sedimentary rocks, the Angayucham terrane (Box and Patton, 1989). The Angayucham is thought to represent imbricated Devonian through Jurassic oceanic crust (Pallister and others, 1989). On the eastern and northern boundaries of the Yukon-Koyukuk basin, from the basin to its flanks, major units have the same structural stacking: marine volcanic and sedimentary rocks sit above younger, continentally derived conglomerates, which sit above oceanic rocks of the Angayucham terrane, which sit above schists with continental protoliths and high-pressure/lowtemperature metamorphic assemblages.

Eastern Seward Peninsula lacks this simple structural stacking. Instead, the marine volcanic and sedimentary rocks of the basin are directly juxtaposed with schists of the Nome Complex, with no intervening oceanic rocks (sh. 2). The oceanic rocks sit west of the Yukon-Koyukuk basin as isolated slivers within a fault zone flanked by the Nome Complex. The fault zone spans eastern Seward Peninsula from north to south, and was named the Kugruk Fault Zone by Sainsbury (1974). Nome Complex rocks are within the fault zone and flank the fault zone on both sides. Sedimentary rocks related to the Yukon-Koyukuk basin (the older part of unit TKs) are also caught as slivers within the fault zone.

The oceanic rocks of eastern Seward Peninsula are considered part of the Angayucham terrane and consist of metabasalt, Jurassic tonalite, and minor serpentinite. Mafic rocks throughout the belt are metamorphosed to blueschist or greenschist facies; fabrics in these rocks are weak to mylonitic. Mafic rocks in the northern part of the Kugruk Fault Zone also retain minerals from an earlier metamorphic event that predated the blueschist-greenschist facies event, while mafic rocks in the southern part of the fault zone contain a single blueschist or greenschist metamorphic assemblage and relict igneous phases. The age of blueschist-facies metamorphism is unknown, and it differs in style and conditions from the blueschist-facies event in the Nome Complex. Although the metamorphic grade of basaltic rocks in the Angayucham terrane elsewhere is generally prehnite-pumpellyite to low greenschist, blue amphiboles are known in correlative oceanic rocks on the flank of the Ruby geanticline (Dusel-Bacon and others, 1989; Roeske and McClelland, 1997).

Two sequences of sedimentary rocks, one likely midCretaceous, the other Late Cretaceous and Tertiary in age, are present within the fault zone. One sequence is dominated by coarse conglomerate rich in locally derived clasts, including Paleozoic marbles and dolostones (most from the Nome Complex) and mylonitic metabasites from the Angayucham terrane (Till and others, 1986). Mid-Cretaceous sedimentary rocks of the adjacent parts of the Yukon-Koyukuk basin are also carbonate-rich (Nilsen, 1989; Patton and others, 2005), and are likely part of the same depositional sequence. Generally finer grained sedimentary sequences that have thick coal seams yielded Late Cretaceous and Tertiary pollen (Till and others, 1986; Dickinson and others, 1987).

Movement on the Kugruk Fault Zone may have recurred over a long time interval. The 100-Ma Darby pluton retains its intrusive contacts and is elongate parallel to the fault zone, suggesting that a structural control to the pluton's shape existed during the Cretaceous. Results from a coal drilling program in the northern part of the Kugruk Fault Zone show that Nome Complex schists sit structurally above Tertiary sedimentary rocks, where the schists must have been placed by reverse faulting (Retherford and others, 1986). Therefore, the Kugruk Fault Zone also was active during the Tertiary.

\section{Igneous Rocks}

Granitoid rocks intruded the Nome Complex during the Cretaceous (fig. 2, on sh. 2). Based on early reconnaissance work and K-Ar ages, three suites of plutons were recognized: an early alkalic group, 110 to $96 \mathrm{Ma}$; a calc-alkaline group, 95 to $80 \mathrm{Ma}$; and a tin granite group, 80 to $69 \mathrm{Ma}$ (Till and others, 1986). These characterizations are in flux.

The alkalic rocks are part of a belt that extends east of Seward Peninsula into the Yukon-Koyukuk basin (Miller, 1989; Arth and others, 1989; Amato and Wright, 1998). The calcalkalic plutons core the Kigluaik Mountains and are common on eastern Seward Peninsula (Till and others, 1986; Amato and Wright, 1998). Magmatism continued with intrusion of plutons 
and alkalic dike swarms (Amato and others, 2003c; Gottlieb and Amato, 2008). During latest Cretaceous time, a suite of tinbearing granites intruded both the Nome Complex and adjacent rocks in western Seward Peninsula (Hudson and Arth, 1983).

Magmatic events on Seward Peninsula are coeval with similar events on Saint Lawrence Island, Alaska, approximately $250 \mathrm{~km}$ southwest of Seward Peninsula, and in the OkhotskChukotsk volcanic belt on the Russian side of Bering Strait, and formed in the same general tectonic regime (Amato and Wright, 1998; Miller and others, 2002; Amato and others, 2003b).

Better delineation of crystallization ages using $\mathrm{U}-\mathrm{Pb}$ zircon geochronology and a deeper understanding of petrogenetic events using modern geochemical tools was initiated by Arth and others (1989) and Amato and others (1994). Continued study of the age and nature of petrogenetic events on Seward Peninsula is underway (for example, Amato and Wright, 1997; Gottlieb and Amato, 2008); the earlier delineation of plutonic suites is in the process of being revised.

In central, eastern, and northern Seward Peninsula, extensive plateau basalts, cinder cones, and very large maars formed during several episodes of volcanism as old as the Oligocene, and as young as the Holocene (Hopkins and others, 1971; Turner and Swanson, 1981).

\section{Tertiary and Active Deformation}

Geomorphologic, structural, and thermal data indicate active deformation on Seward Peninsula occurred in Tertiary to Recent times. Along the coastline south of the York Mountains, terraces were uplifted during the late Pleistocene (Sainsbury, 1967). Active normal faults, which are marked by sag ponds, offset streams, scarps and other features, bound the Kigluaik and Bendeleben Mountains (Kaufman, 1985; Plafker and others, 1994), and expose the high-grade metamorphic rocks. Apa- tite fission-track data show that significant slip on these faults started in the Eocene (Dumitru and others, 1995). A transition from Nome Complex detritus to detritus that also includes high-grade minerals was recognized in wells drilled in Tertiary (Paleogene) offshore basins (Forbes and others, 1984; Tolson, 1987). Based on gravity data, basins sit below McCarthy Marsh, south of the Bendeleben Mountains, and the Imuruk basin, north of the Kigluaik Mountains (Barnes and Hudson, 1977; Barnes and Morin, 1988); these basins are likely the same age as those offshore.

Tertiary activity along the Kugruk Fault Zone included reverse faulting (Retherford and others, 1986) as well as early Eocene graben formation (Dickinson and others, 1987). Death Valley, in the northern Darby Mountains, is likely a Tertiary feature.

\section{Acknowledgments}

We are indebted to Anita G. Harris, who, with tremendous dedication and perseverance, processed hundreds of kilograms of rock and picked through vast numbers of metamorphic grains to find the conodonts contained in Nome Complex carbonate rocks. We are thankful for her willingness to take on such rocks, and for her good humor in helping us understand them. We are grateful to Travis Hudson for suggesting that we concentrate early mapping efforts (in the 1980's) in the western Solomon quadrangle. His advice was right on the mark - it is the area in which the internal structure of the Nome Complex was most easily identified. We also thank Dr. Hudson, as well as Timothy R. Carr and Jaime Toro, for contributing previously unpublished conodont data from the Teller quadrangle. Sincere thanks to Jeff Amato for providing unpublished geochronology data.

\section{DESCRIPTION OF MAP UNITS}

\section{SURFICIAL DEPOSITS}

Qs Surficial deposits, undivided (Quaternary) — Frost-rived rubble on slopes and broad low ridges; glacial moraine; glacially deposited sand, gravel, and boulders; fluvial gravel and sand; marine and fluvial terrace deposits; wetlands

\section{MESOZOIC AND CENOZOIC IGNEOUS ROCKS}

Qlj Lost Jim Basalt (Holocene) - A single basaltic lava flow and associated vent deposits, undisrupted by frost brecciation, located in central Bendeleben quadrangle (fig. 2, on sh. 2). The dark gray-black vesicular olivine basalt in eastern part of the unit exhibits pahoehoe flow features and lava tubes. Maximum age is constrained to be less than $0.8 \mathrm{Ma}$ based on stratigraphic position above unit QTv (Turner and Swanson, 1981)

QTv Weathered volcanic rocks, undivided (Quaternary and Tertiary) — Basalt lava flows, vent deposits, maar volcanoes and associated pyroclastic rocks exposed in northern, central, eastern, and to a minor extent, southern Seward Peninsula (fig. 2, on sh. 2).

Less weathered rocks are slightly to strongly fragmented by frost riving and locally overlain by windblown silt. These rocks include alkali olivine basalt and olivine tholeiite. Alkalic rocks contain phenocrysts of olivine with plagioclase, augite, and spinel in the groundmass. Tholeiitic rocks contain plagioclase, phenocrysts with augite, hypersthene, 
olivine, and spinel in the groundmass (Swanson and others, 1981). These less weathered volcanic rocks underlie portions of the Lost Jim Basalt in central Bendeleben quadrangle, and include the Camille Basalt and Gosling Volcanics of Hopkins (1963), as well as small flows in valley centers on the south flank and south of the Bendeleben Mountains. Potassiumargon (K-Ar) determinations on basalt from Kugruk River canyon (Turner and Swanson, 1981) and from the northwest flank of the Bendeleben Mountains (Kaufman and Hopkins, 1985 ) indicate that the Gosling Volcanics were in part extruded between 0.9 and $0.8 \mathrm{Ma}$. The Camille Basalt is younger by an unknown amount of time. Equivalent to unit "Qv" of Till and others (1986). In southern Seward Peninsula, a small basaltic vent and associated flows yielded a ${ }^{40} \mathrm{Ar} /{ }^{39} \mathrm{Ar}$ whole rock age of approximately $0.8 \mathrm{Ma}$ (Werdon and others, 2006).

Other volcanic rocks are thoroughly fragmented by frost action. These are the most widely distributed and voluminous volcanic rocks on the peninsula; they underly most of the Imuruk Lake lava plateau but are mapped only where exposed through an otherwise 1- to 6-m thick mantle of windblown silt. The rocks are mostly alkali olivine basalt with phenocrysts of olivine with plagioclase, augite, and spinel in the groundmass. Lesser olivine tholeiite contains plagioclase phenocrysts with augite, hypersthene, olivine, and spinel in the groundmass (Swanson and others, 1981). This part of the unit includes the Imuruk Volcanics of Hopkins (1963), which are between 2 and $5 \mathrm{Ma}$ (Hopkins and others, 1971; Turner and Swanson, 1981). Flows of the Imuruk Volcanics were confined by modern valley systems that drained north from Imuruk Lake area and, as a result of subsequent stream incision, are exposed as bench remnants high on valley walls. South and east of Imuruk Lake, older volcanic rocks cap ridge tops. These older flows are between 26 and $29 \mathrm{Ma}$ (Turner and Swanson, 1981). In southeastern Bendeleben quadrangle, basalt flows are interlayered with sedimentary rocks that have yielded early Eocene pollen (Dickinson and others, 1987). Equivalent to unit "QTv" of Till and others (1986).

The older volcanic units contain xenoliths of dunite, harzburgite, chromite, granite, and schist (Hopkins, 1963). Dunite xenoliths are most common, and reached 7-8 cm across. Granite and schist xenoliths are smaller (less than $2 \mathrm{~cm}$ across) and occur only where the volcanics erupted through granitic or metamorphic bedrock. Similar xenoliths in correlative volcanic rocks in western Alaska and on Saint Lawrence Island have had more detailed study (for example, Wirth and others, 2002).

The Late Quaternary Espenberg Maars, 30-50 km southwest of Cape Espenberg on northern Seward Peninsula, consist of four large craters ranging from 4 to $8 \mathrm{~km}$ in diameter surrounded by coeval tephra layers. These craters, known as Devil Mountain, Whitefish, North Killeak, and South Killeak Maars (fig. 2, on sh. 2), are each separate eruption craters excavating 100 to $300 \mathrm{~m}$ into Pleistocene sediments and lavas (Hopkins, 1988). The maars are surrounded by a thick blanket of pyroclastic surge and airfall tephra deposits. Cliffs around Devil Mountain Maar expose sequences of bedded surge deposits, airfall lapilli beds, scoria, massive pyroclastic flows and explosion breccia (Begét and others, 1996). This volcaniclastic sediment is evidence that the Espenberg Maars were formed by highly explosive hydromagmatic eruptions through permafrost, which ultimately created the unusually large maar craters. Devil Mountain Maar is $8 \mathrm{~km}$ long by $6 \mathrm{~km}$ wide, as much as $200 \mathrm{~m}$ deep, and covers over $30 \mathrm{~km}^{2}$. It is the largest known maar on earth; the three other maars on Seward Peninsula are also larger than any previously described maar.

Mafic volcanic rocks of this unit are one of several Cenozoic volcanic fields in western Alaska that extend from northern Seward Peninsula to Saint Lawrence Island and the Pribilof Islands on the Bering Sea shelf (Moll-Stalcup, 1994); the Pribilof Islands are about 840 $\mathrm{km}$ south-southwest of Nome

TKv Felsic volcanic rocks (Tertiary and Cretaceous) - Rubble crop of volcanic rocks in northeastern part of the map area, in Bendeleben D-1 quadrangle (fig. 2, on sh. 2). Unit consists of two varieties of volcanic rock, both moderately to strongly limonite stained. One is a volcanic flow or tuff that contains up to $4 \%$ phenocrysts in an aphanitic, devitrified groundmass. Phenocrysts are predominately sanidine with rare quartz and plagioclase. No mafic minerals are present, but morphology of rare aggregates of sericite, opaques and limonite suggest the former presence of biotite. The second type of volcanic rock is fragmental and contains schist, devitrified volcanics, and angular quartz fragments in a felsic(?), sericite-bearing matrix. It may be a volcanic flow breccia or vent breccia rock. Age of unit is unknown. Felsic tuffs on Saint Lawrence Island have yielded a K-Ar age of 39.3 Ma (Patton and Csejtey, 1980) 
Tin-bearing granitic stocks (Late Cretaceous) - Stocks of biotite granite exposed in outcrop, rubble, and float in northwestern Seward Peninsula. Includes stocks at Cape Mountain, Brooks Mountain, Black Mountain, Ear Mountain, and the Oonatut Granite Complex (fig. 2, on sh. 2). The belt also includes bodies not exposed at the surface at Lost River Mines and Kougarok Mountain (fig. 2, on sh. 2). Stocks are dominantly biotite granite with lesser aplitic and pegmatitic phases (Hudson and Arth, 1983). Larger stocks, such as the Oonatut, are texturally zoned. Contacts with country rocks are sharply crosscutting, and contact aureoles are narrow. Epizonal stocks have high ${ }^{87} \mathrm{Sr} /{ }^{86} \mathrm{Sr}$ initial ratios and elevated $\mathrm{Th}, \mathrm{U}, \mathrm{Hf}$, and Ta (Hudson and Arth, 1983). Potassium-argon (K-Ar) biotite ages range from $69.2 \pm 2$ to $80.2 \pm 3 \mathrm{Ma}$ (Hudson and Arth, 1983). Tin lodes and placers are associated with the stocks (Reed and others, 1989). Tin and tungsten were commercially mined in Lost River area, western Teller quadrangle (Sainsbury, 1969b)

Kds Dikes and stocks (Cretaceous) - Dikes and rare stocks of a variety of compositions and ages mapped extensively in the York, Kigluaik, and Bendeleben Mountains, and near the Darby Mountains, but also present in the Nome Complex. Some, but not all, are shown on the map as small pink lines.

The oldest dike known is an analcime-biotite-nepheline syenite that intruded the Nome Complex in central Solomon quadrangle and yielded a biotite ${ }^{40} \mathrm{Ar} /{ }^{39} \mathrm{Ar}$ age of $107 \mathrm{Ma}$ (Werdon and others, 2005a). A group of alkalic dikes, nepheline syenite and pseudoleucite porphyries, are exposed as frost-riven rubble in Solomon C-2, C-3 and D-3 quadrangles and intruded portions of the Kachauik pluton and adjacent marble. The dikes are up to $10 \mathrm{~m}$ wide and have strike lengths up to $900 \mathrm{~m}$. They strike mostly to the northeast and are vertical. Syenite of the Kachauik pluton is highly radioactive adjacent to the dikes, containing up to $0.15 \% \mathrm{U}_{3} \mathrm{O}_{8}, 1.05 \% \mathrm{ThO}_{2}$ and $\%$ rare earth elements (Miller and Bunker, 1976). Dikes yielded a K-Ar biotite age of $96.3 \pm 3 \mathrm{Ma}$ (Berry and others, 1976).

Alkali feldspar granite to quartz monzodiorite pegmatite dikes and sills are common at the core of the Kigluaik Mountains, in the western Bendeleben Mountains, and in the Darby Mountains, but are not found in rocks of lower metamorphic grade. A foliated pegmatite dike that cut high-grade metamorphic rocks in the Bendeleben Mountains yielded a U-Pb zircon age of $99 \pm 2 \mathrm{Ma}$ (Gottlieb and Amato, 2008).

Dark-brown- to orange-weathering alkalic diabase dikes are widespread on Seward Peninsula, but best documented in high-grade metamorphic rocks that underlie mountain ranges. Alkalic diabase dikes cut high-grade rocks and Cretaceous plutons in the Kigluaik and Bendeleben Mountains; dikes are up to $5 \mathrm{~m}$ across and yield ${ }^{40} \mathrm{Ar} /{ }^{39} \mathrm{Ar}$ ages of approximately 83 Ma (Calvert and others, 1999; Amato and others, 2003c). Similar brown- to orange-weathering alkalic mafic dikes in the Nome Complex are exposed in scattered locations on southern Seward Peninsula; in Solomon quadrangle, mafic dikes yielded ${ }^{40} \mathrm{Ar} /{ }^{39} \mathrm{Ar}$ ages of 80 to $84 \mathrm{Ma}$ (Werdon and others, 2005a; Newberry and others, 2005; Werdon and others, 2006).

In the Bendeleben Mountains, light-tan- to orange-weathering, altered, porphyritic dikes, sills and small plugs of quartz latite are about the same age as the regionally widespread diabase dikes. In Bendeleben A-4 quadrangle, dikes are up to $12 \mathrm{~m}$ across and have aphanitic groundmass, feldspar and quartz phenocrysts, and altered mafic phenocrysts. Textures in dikes, sills and plugs indicate crystallization at shallower levels than the nearby granite bodies and pegmatite dikes. Gottlieb and Amato (2008) reported a U-Pb zircon age of $82 \pm 1$ Ma for a hypabyssal porphyritic dike, likely from this group of dikes. Dikes may be, in part, equivalent to unit "Kql" (quartz latite porphyry) and unit "Khi" (hypabyssal intrusive rocks) mapped by Miller and others (1972), and the "rhyolites of the western Bendeleben Mountains" of Turner and Swanson (1981). Similar intermediate to felsic dikes are exposed in the southern Darby Mountains, but their age is unknown.

In western Nome quadrangle, biotite- and hornblende-bearing granitic dikes and lesser tourmaline-bearing pegmatite dikes cut folded and coarsely recystallized marble (unit Pzmm). K-Ar ages of $80.5 \pm 0.8 \mathrm{Ma}$ (biotite) and $84.2 \pm 0.9 \mathrm{Ma}$ (hornblende) from the dikes are cooling ages (N. Shew, written commun., 1993); the hornblende age more closely approximates the intrusive age

Kp Pargon pluton (Cretaceous) - Fine-grained equigranular, fine- to medium-grained seriate granodiorite, monzodiorite, and locally monzogranite exposed in the western Bendeleben Mountains along the upper reaches of the Pargon River (fig. 2, on sh. 2). Granodiorite and quartz 
monzonite are the dominant lithologies. Upper contact of the pluton is preserved locally. Pargon pluton yielded a U-Pb zircon age of $86 \pm 1 \mathrm{Ma}$ (Gottlieb and Amato, 2008)

Kdi Kigluaik diorite (Cretaceous) - Fine- to medium-grained potassic mafic rocks of the lower part of the Kigluaik pluton, including biotite hornblende diorite, quartz diorite, granodiorite, tonalite, and gabbro, exposed in the western Kigluaik Mountains (fig. 2, on sh. 2; Amato and others, 1994; Amato and Miller, 2004). Geochemical and isotopic data indicate these mafic rocks are genetically related to the Kigluaik granite (unit $\mathrm{Kg}$ ), the upper, more voluminous part of the pluton (Amato and Wright, 1997). Mineral thermometry indicates intrusion at pressures of 3-5 kb; together, units $\mathrm{Kdi}$ and $\mathrm{Kg}$ are thought to have formed in a subduction zone setting (Amato and Wright, 1997). Crystallization age of $90 \pm 1 \mathrm{Ma}$ (Amato and Wright, 1998)

Kg Kigluaik granite (Cretaceous) - Fine- to medium-grained felsic rocks of the upper part of the Kigluaik pluton (fig. 2, on sh. 2), including leucocratic biotite granite and granodiorite (Amato and Miller, 2004). Unit is more extensively exposed than the mafic root, the Kigluaik diorite (unit Kdi), and contains minor amounts of alkali feldspar granite and quartz syenite (Amato and others, 1994; Amato and Wright, 1997). Contact with the underlying mafic root (Kdi) is a 10- to 20 -m-thick "mixing/mingling" zone characterized by mafic enclaves in a granitic matrix; textures suggest that unit is the same age as unit Kdi (Amato and Wright, 1997). The upper contact of unit with the overlying metamorphic rocks is locally exposed (Amato and Wright, 1997). Geochemical characteristics of units Kg and Kdi indicate formation in a subduction zone setting (Amato and Wright, 1997)

Ks Stocks, undifferentiated (Cretaceous) - Frost-riven outcrops, rubble fields, and float of felsic intrusive rocks at four localities align along a roughly north-south trend in Bendeleben $\mathrm{C}-3$ and D-3 quadrangles (fig. 2, on sh. 2). The northernmost, Crossfox Butte stock, is monzogranite to quartz monzonite with rare leucocratic syenite that contains several percent purple fluorite, muscovite, and minor scheelite. Country rock rubble around the stock consists of hornfelsed marble and calc-silicate rocks. A biotite K-Ar date of 91.5 $\pm 2.8 \mathrm{Ma}$ is considered suspect due to chloritization of the biotite (Till and others, 1986). The Asses Ears stock is monzogranite to syenogranite and strikingly porphyritic, with alkali feldspar phenocrysts 2 to $4 \mathrm{~cm}$ long. The Virginia Butte stock is quartz monzonite to syenite that yielded a biotite K-Ar date of $94.8 \pm 1.9 \mathrm{Ma}$ (Till and others, 1986). The southernmost, Nimrod Hill stock, is monzonite but contains rare biotite-rich diorite. Hornblende from Nimrod Hill yielded a K-Ar age of $96.3 \pm 2 \mathrm{Ma}$ (N. Shew, written commun., 1990). Aeromagnetic data suggest the stock extends west under Imuruk Lake and also suggest a possible connection with the Virginia Butte and Asses Ears stocks to the north (J. Cady, written commun., 1986)

Kku Kugruk pluton (Cretaceous) - Frost-riven rubble in northeast corner of Bendeleben C-2 quadrangle (fig. 2, on sh. 2). Quartz monzonite to quartz monzodiorite. Green porphyritic rocks of approximately dioritic composition at the eastern margin of the pluton may be a border phase. Aeromagnetic data suggest that the pluton is larger than mapped (J. Cady, written commun., 1986). Biotite produced a K-Ar date of 94.8 $\pm 2.8 \mathrm{Ma}$ (Till and others, 1986)

Kwc Windy Creek pluton (Cretaceous) - Talus and frost-riven rubble at north end of the Darby Mountains in Bendeleben A-1 and A-2 quadrangles. Rock type is quartz monzonite that is locally cut by biotite granodiorite dikes (fig. 2, on sh. 2). Blocks or roof pendants of metamorphic rocks are locally common, especially in western portion of the pluton. A large block of marble, schist and calc-silicate hornfels is contained within eastern portion of the pluton. Miller and others (1972) found boulders of nepheline syenite in streams that drain east side of the pluton. Portions of pluton are altered and veined. Alteration consists of limonite staining, weak to strong sericitization of plagioclase, and variable chloritization and sericitization of hornblende. Two types of veins are present: (1) rare pieces of quartz vein material up to $15 \mathrm{~cm}$ across containing several percent fluorite, 1 to 2 percent molybdenite, and galena and sphalerite; and (2) thin, mostly $<3 \mathrm{~mm}$ but up to $1 \mathrm{~cm}$, veinlets containing quartz and pyrite \pm fluorite, molybdenite, scheelite and minor galena and sphalerite. Although these veinlets crosscut each other, they do not constitute a stockwork system. Yielded a hornblende K-Ar age of 93.8 $\pm 2.1 \mathrm{Ma}$ (N. Shew, written commun., 1987), and a U-Pb zircon age of $96.5 \pm 0.2$ (R.Friedman, written commun., 2009)

Kd Darby pluton (Cretaceous) —Elongate monzogranite, locally granodiorite pluton $80 \mathrm{~km} \mathrm{long}$ and 3 to $8 \mathrm{~km}$ wide that extends along crest of the Darby Mountains in southeast part of the peninsula (fig. 2, on sh. 2). Outcrops are common in northern part of the pluton; frost-riven 
rubble predominates elsewhere. Pluton is characterized by phenocrysts of alkali feldspar up to $5 \mathrm{~cm}$ long. Some gradual zonation of mineralogy: hornblende content decreases slightly to north; plagioclase content decreases slightly to north with a corresponding increase in alkali feldspar and quartz contents. Rounded or ellipsoidal inclusions of a mafic igneous rock are common. K-Ar ages range from $96.4 \pm 3$ Ma to $90.5 \pm 1.5$ (Miller and Bunker, 1976). Yielded a U-Pb zircon age of 100.1 \pm 0.1 (R.Friedman, written commun., 2009)

Kkd Diorite (Cretaceous) - Hybrid diorite of the Kachauik pluton; exposed in Solomon B-2 quadrangle (fig. 2, on sh. 2). Unit is coarse grained and characterized by abundant biotite and may be a border phase of the monzonite-syenite (unit Kkms) of the Kachauik pluton (Miller and others, 1972)

Kkg Granodiorite (Cretaceous) - Granodiorite-quartz monzonite phase of the Kachauik pluton, exposed in frost-riven rubble, talus and outcrop in Solomon C-2 and D-2 quadrangles (fig. 2 , on sh. 2). Unit is cut by aplite, quartz latite porphyry, lamprophyre and alkaline dikes (Miller and others, 1972)

Kkms Monzonite-syenite (Cretaceous) - Monzonite-syenite phase of the Kachauik pluton; exposed as frost-riven rubble, talus and outcrop in Solomon B-2, C-2 and D-2 quadrangles (fig. 2, on sh. 2). This phase is the most voluminous phase of the pluton, and is cut by aplite, quartz latite porphyry, lamprophyre, and alkaline dikes. K-Ar hornblende cooling age of $99.9 \pm 3 \mathrm{Ma}$ (Miller and others, 1972; Miller and Bunker, 1976)

Kkgm Gneissic monzonite (Cretaceous) - Gneissic monzonite of the Kachauik pluton; exposed in Solomon C-2 quadrangle (fig. 2, on sh. 2). Unit has a gneissic to trachytoid texture, and may be a border phase of the monzonite-syenite (unit Kkms) of the Kachauik pluton (Miller and others, 1972)

Kbk Bendeleben and Kuzitrin plutons (Cretaceous) - Monzogranite and granodiorite; outcrop, talus, rubble, and some cirque headwall exposures in eastern Bendeleben Mountains in Bendeleben A-2, A-3, B-2 and B-3 quadrangles, and small rubble fields north of the range in Bendeleben C-3 quadrangle (fig. 2, on sh. 2). Known as two separate plutons, aeromagnetic data show that they are connected at depth, and they have similar chemistry, mineralogy, and cooling histories; they are lobes of the same large body. Contacts of both Bendeleben and Kuzitrin lobes with surrounding metamorphic rocks are not sharp, but rather are broad, several-kilometer-thick zones of mixed metamorphic and granitic rocks. Percentage of granitic rocks in contact zone decreases with distance from the two lobes. The Bendeleben lobe is monzogranite to quartz monzodiorite; contacts between these two phases do not appear to be gradational. Inclusions of plagioclase-biotite-pyroxene-quartz schist are locally common, and spectacular exposures of large inclusions or blocks of schist are present on northeast side of ridge in sec. 7, T. 3 S., R. 19 W. (Bendeleben A-2 quadrangle). Varying degrees of assimilation of this schist may account for the mineralogical and lithological variations. The Kuzitrin lobe is predominantly monzogranite and less well exposed. A U-Pb zircon crystallization age of $104 \pm 1 \mathrm{Ma}$ was obtained from a foliated part of western Bendeleben pluton (Gottlieb and Amato, 2008). Biotite from Bendeleben lobe yielded a K-Ar age of 81.1 \pm 2 (Miller and Bunker, 1976; location 61 on sh. 2); a biotite

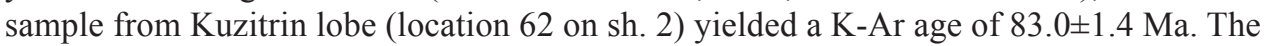
biotite ages record pluton cooling

Dry Canyon stock (Early Cretaceous) - Frost-riven rubble of nepheline syenite on west side of Darby Mountains in Solomon D-2 quadrangle (fig. 2, on sh. 2). Unit has a trachytoid fabric and yielded a K-Ar hornblende age of $108 \pm 3 \mathrm{Ma}$ (Miller, 1972)

Kgr Granite and granodiorite (Early Cretaceous) - Equigranular biotite-hornblende quartz monzonite exposed along eastern boundary of map area in Candle quadrangle, at Granite Mountain and in the "J" shaped Quartz Creek pluton (fig. 2, on sh. 2). Quartz monzonite at the core of the zoned Granite Mountain body grades into adjacent rocks of unit Ksy; the two rock types are thought to be comagmatic. Monzonite of adjacent unit Ksy yielded a hornblende K-Ar age of 108.6 $\pm 3 \mathrm{Ma}$ (Miller, 1972). Both bodies of quartz monzonite are part of the "western Yukon-Koyukuk plutonic suite" of Miller (1989), a potassic and ultrapotassic belt that extends from Seward Peninsula eastward into the Yukon-Koyukuk basin. Equivalent to unit "Kgr" of Patton and others (2005)

Ksy Syenite, monzonite, and nepheline syenite (Early Cretaceous) - Syenite, monzonite, and subordinate quartz monzonite, monzodiorite, quartz syenite, nepheline syenite and related mafic alkaline rocks of Patton and others (2005); exposed along eastern boundary of map area, in 
Candle quadrangle (fig. 2, on sh. 2). Part of the "western Yukon-Koyukuk plutonic suite" of Miller (1989), a potassic and ultrapotassic belt that extends from Seward Peninsula eastward into Yukon-Koyukuk basin. Hornblende K-Ar age of 108.6 \pm 3 Ma was obtained from the monzonite phase of Granite Mountain pluton (Miller, 1972). Equivalent to units "Ksy" and "Knsy" of Patton and others (2005)

Kv

Kgu

\section{Granit} scattered localities (fig. 2, on sh. 2). Most commonly these bodies occur within exposures
of high-grade metamorphic rocks (unit PzPh), but unit is also present in the Nome Complex and on islands off the south and west coasts of the peninsula. Unit includes small bodies of anatectic biotite granite in southern Darby Mountains at Mount Arathlatuluk (107.8 \pm 0.2 $\mathrm{U}-\mathrm{Pb}$ zircon age), thought to be melts of the surrounding high-grade metamorphic rocks. Several bodies in western and easternmost Bendeleben Mountains intruded high-grade metamorphic rocks; small granitic bodies intruded the Nome Complex north of Death Valley, just south of the east end of the Bendeleben Mountains, and in the northeast Bendeleben quadrangle, near the boundary between the Bendeleben and Candle quadrangles. Fairway Rock, a small island directly west of the peninsula near Little Diomede Island, is a porphyritic hypersthene-bearing granite, with orthoclase crystals up to $10 \mathrm{~cm}$ long that are locally aligned in a fabric (Shumway and Moore, 1964). Biotite from Fairway Rock yielded a K-Ar biotite age of $110.7 \pm 3 \mathrm{Ma}$, similar to ages to alkalic intrusives on Seward Peninsula (tables 2 and 3). Little Diomede Island, King Island, and Sledge Island are biotite-hornblende quartz monzonites or granites of unknown age (Sainsbury, 1972; Sainsbury and others, 1972). Extremely variable accessory mineralogy. Undated bodies are assumed also to be Cretaceous in age

\section{YORK TERRANE}

\section{YORK MOUNTAINS SUCCESSION}

DSI Limestone (Devonian and (or) Silurian) _Light-gray-weathering, medium-dark-gray limestone exposed in a small, fault-bounded area in central Teller quadrangle. Lithofacies include cherty lime mudstone, peloidal wackestone, and lesser coralline packstone. Lower beds produced relatively long-ranging conodonts but upper beds yielded conodonts of middle Silurian (middle Wenlock) age and Silurian (probably middle to late Silurian) corals; the fauna indicates a warm, relatively shallow water, normal-marine depositional setting (table A-1; W. Oliver, unpub. fossil report, 1974; Till and Dumoulin, 1994). DSI has also yielded corals thought to be of probable Middle or Late Devonian age (Oliver and others, 1975); the age of this collection was later revised to late Silurian (late Ludlow)early Late Devonian (Frasnian), probably late Silurian to Early Devonian, by A. Pedder (Dumoulin and Harris, 1994; Till and Dumoulin, 1994). This revised age is younger than that of any other definitively dated lower Paleozoic rocks in the York terrane. Lithology and age of unit broadly correlate with all or parts of units SOdl and SOul of the York terrane and units Sd, DOx (overlay), and Ddm of the Nome Complex. Equivalent to unit "Dl" of Sainsbury (1972)

SOdl Dark limestone (Silurian and Upper Ordovician)-Medium- to thick-bedded, light-brown to dark-gray limestone, dolomitic limestone, and dolostone, locally cherty, commonly very fossiliferous, exposed in a fault-bounded area in northeastern York Mountains (Teller quadrangle; "section on Don River" of Sainsbury and others, 1971).

Ordovician rocks, at least $120 \mathrm{~m}$ thick, consist of wackestones and packstones, with peloids and skeletal grains in a micritic matrix. Fossils are Late Ordovician and include conodonts (table A-1; Dumoulin and Harris, 1994), corals (Oliver and others, 1975; R.J. Elias in Blodgett and others, 2002, p. 283), trilobites (Ormiston, 1978; Ormiston and Ross, 1979), and brachiopods, cephalopods, gastropods, ostracodes, pelecypods, and stromatoporoids (Sainsbury, 1969a; Sainsbury and others, 1971; Rohr, 1979, 1988; Potter, 
1984; Rohr and Potter, 1987; Rohr and others, 2003). Rugose corals (Bighornia) indicate a possibly Richmondian age (Dumoulin and Harris, 1994).

The Silurian section, at least $220 \mathrm{~m}$ thick, consists mainly of mudstone and bioclastic wackestone and packstone and contains more dolostone than the Ordovician part of the unit. Shallowing-upward cycles, 5 to $8 \mathrm{~m}$ thick, occur throughout. Megafossils form local buildups and include corals (Oliver and others, 1975), stromatoporoids, bryozoans, and brachiopods of middle and late Silurian age (Sainsbury and others, 1971). Biostratigraphically diagnostic conodonts are of early and earliest late Silurian ages (table A-1; Dumoulin and Harris, 1994; Till and Dumoulin, 1994).

Features such as fenestral fabric, micritized bioclasts, algal lamination, conodont biofacies, and the abundance and diversity of corals and stromatoporoids all indicate that SOdl was deposited in warm, shallow to very shallow water in a locally restricted platform setting. Ordovician conodonts and megafossils include both Siberian and Laurentian (North American) endemic forms (Dumoulin and Harris, 1994; Blodgett and others, 2002; Dumoulin and others, 2002). Silurian fossils are mainly cosmopolitan.

Unit SOdl is at least partly correlative with unit SOul; it is also partly correlative with, but much more fossiliferous than, Silurian metacarbonate rocks in units Sd and DOx (overlay) of this map. Faunas and lithofacies of SOdl correlate well with those from ageequivalent strata in the Baird Group (Tailleur and others, 1967; Dumoulin and Harris, 1994) and related units in western and central Brooks Range (units "DOb" and "DOc" of Till and others, 2008b) and of the Telsitna Formation and related rocks in the Farewell terrane of interior Alaska (Dumoulin and Harris, 1994; Dumoulin and others, 2002). SOdl is equivalent to units "SOdl" and "Sl" of Sainsbury (1969a, 1972)

SOul Limestone and dolostone, undifferentiated (Silurian and Ordovician) - Carbonate rocks equivalent to unit Ols and (or) unit SOdl, but less well studied than those units; exposed in three small fault-bounded areas in central part of the Teller quadrangle. The western and central exposures are limestone with corals of Late Ordovician (Sainsbury, 1969a,b; Sainsbury and others, 1971) or late Middle to early Late Ordovician (Oliver and others, 1975) age. The eastern exposure is near the eastern boundary of the York terrane and consists of very fine-grained, locally cherty, gray dolostone that contains long-ranging conodonts, domal to laminar stromatoporoids, and diverse tabulate and rugose corals of Silurian, probably late Llandovery-Wenlock age (table A-1). Conodonts from this locality have a CAI value of 5, one of the highest known from the York terrane (table A-1). Equivalent to unit "Oum" of Sainsbury (1969a,b, 1972)

Ols Limestone and shale (Ordovician) - Thin- to medium-bedded, pale-orange- to pale-yellowbrown-weathering, medium-gray to black limestone, dolomitic limestone, and dolostone with local shale and chert nodules. Unit Ols forms subdued slopes within, north of, and east of the York Mountains; the unit is generally fault bounded, but locally depositionally overlies unit Ol. The lower 7 to $30 \mathrm{~m}$ of Ols is fissile black shale and lesser interbedded black limestone and dolomitic limestone that contains calcified and pyritized radiolarians and sponge spicules (T. Carr and T. Hudson, written commun, 1982; Dumoulin and Harris, 1994). Lower strata grade upward into flaggy, thin-bedded black limestone with shaly partings and soft-sediment deformation features, and then into thin-bedded, sparsely bioclastic limestone and dolostone that is graded, crossbedded, and bioturbated. Ols is at least 300 m thick (Dumoulin and Harris, 1994), and it appears to contain the Early-Middle Ordovician boundary near its base (Dutro in Ross and others, 1982). The unit produced pandemic, cool-water conodonts of earliest Middle Ordovician (latest Arenig and earliest Llanvirn) age (table A-1; Dumoulin and Harris, 1994), as well as cephalopods, graptolites, gastropods, and trilobites (Ross, 1967; Sainsbury, 1969b; Dutro in Ross and others, 1982). The youngest beds in Ols occur in a small klippe, $0.5 \mathrm{~km}$ in diameter, west of the Mint River in the northwestern York Mountains (unit "Odl" of Sainsbury, 1969b) and consist of medium-bedded, mottled to laminated, gray to brown lime mudstone and dolostone that contain conodonts, corals, and cephalopods of late Llanvirn age (Flower, 1968; Sainsbury, 1969b; Dumoulin and Harris, 1994). Bedforms, sedimentary structures, and faunas indicate that Ols was deposited in a shallowing-upward, basin to peri-platform environment; the youngest strata accumulated in a mid- to outer-platform setting (Dumoulin and Harris, 1994). Lithofacies and biofacies of Ols correlate well with those of deeper water Middle Ordovician strata in the western and central Brooks Range (unit "OBc" of Till and others, 2008b; Dumoulin and 
Harris, 1994). Equivalent to units "Os" and "Oshd" of Sainsbury (1969a), "Olsh" and "Odl" of Sainsbury (1969b), and "Oshl" and "Oshd" of Sainsbury (1972)

Limestone (Ordovician) - Mainly massive to thick-bedded, light-brownish-gray to mediumgray, fine-grained limestone with local chert nodules and lesser interbeds of argillaceous limestone and shale, widely exposed in and adjacent to the York Mountains in western and central Teller quadrangle. Unit Ol is at least $450 \mathrm{~m}$ thick (Dumoulin and Harris, 1994); it resembles unit Oal in containing 8- to 15-m-thick shallowing-upward cycles (Vandervoort, 1985 ) and locally abundant trace fossils, but differs in containing more megafossils and lacking quartzose grainstone and ripple marks. Common rock types include lime mudstone, bioclastic wackestone, and fine grained to very fine grained peloid and intraclast grainstone. The upper $70 \mathrm{~m}$ of the unit is a distinctive blue-gray-weathering, white to pinkish-gray lime mudstone with rare trilobite fragments. Most exposures of Ol are bounded by faults, but at a few localities it appears to grade upward into unit Olsh. Sainsbury (1969b) suggested that Ol conformably overlies unit Oal, but megafossil and conodont data suggest that the lower part of Ol may be coeval with much of unit Oal. Unit OI is chiefly of Early Ordovician (early and middle Arenig) age. The tightest ages are based on conodonts and include collections restricted to the Mac. dianae, Ac. deltatus-On. costatus, lower Oe. communis, and Re. andinus-T. laevis Zones (table A-1); the two youngest of these collections are from near the top of $\mathrm{Ol}$ and are definitively younger than any faunas recovered from unit Oal. Megafossils in Ol include brachiopods, cephalopods, echinoderm debris, gastropods, and trilobites (Ross, 1965; Flower, 1968; Sainsbury, 1969b). Graptolitic shale of early Arenig age (T. fruticosus Zone; C. Carter, 1994, unpub. fossil report) forms local lenses in Ol.

Lithofacies and biofacies indicate that $\mathrm{Ol}$ accumulated in a range of subtidal to supratidal environments within a deepening-upward regime (Dumoulin and Harris, 1994); overall, Ol appears to have formed in somewhat deeper water than unit Oal. Conodont assemblages in Ol include both Siberian and Laurentian (North American) endemic forms (Dumoulin and Harris, 1994; Dumoulin and others, 2002); trilobites have Siberian affinities (Ormiston and Ross, 1979). Unit Ol correlates well with older parts of unit Od in the Nome Complex and the Baird Group (Tailleur and others, 1967; Dumoulin and Harris, 1994) in the western Brooks Range (unit "DOb" of Till and others, 2008b), and with the Novi Mountain Formation, lower Telsitna Formation, and related rocks in the Farewell terrane of interior Alaska (Dumoulin and Harris, 1994; Dumoulin and others, 2002). Equivalent to units "Ol" and "Olu" of Sainsbury (1969a,b, 1972)

Oal Argillaceous limestone and limestone (Ordovician)-Thin-bedded, argillaceous, silty and (or) dolomitic limestone, lesser massive micritic limestone, and local chert; rocks are light gray to medium gray and weather light gray to orange to tan. The unit is widely exposed in and adjacent to the York Mountains in western and central Teller quadrangle, and is at least $350 \mathrm{~m}$ thick (Dumoulin and Harris, 1994). Like unit OI, it contains 8- to 15-m-thick shallowing-upward cycles (Vandervoort, 1985) and locally abundant trace fossils, but Oal is less fossiliferous than unit $\mathrm{Ol}$ and includes quartzose grainstone and ripple marks not seen in unit Ol. Common rock types in Oal are dolomitic, locally argillaceous lime mudstone and grainstone made up mainly of peloids and intraclasts with lesser bioclasts and ooids. Mudsupported strata are bioturbated, with bedding-plane feeding trails and subvertical burrows. Grain-supported rocks are planar to crossbedded with locally well developed oscillation and current ripples. Some grainstones contain 10 to 40 percent fine-sand- to silt-size non-carbonate grains, mainly quartz and lesser feldspar, with trace amounts of pyroxene, zircon, and leucoxene (Sainsbury, 1969b).

Most exposures of Oal are fault bounded, and its original depositional relations with other units in the York Mountains are uncertain. Sainsbury (1969b) reported that Oal conformably underlies unit Ol, but megafossil and conodont data suggest that the upper part of Oal is coeval with much of unit Ol. Unit Oal is chiefly of Early Ordovician (Tremadoc-early Arenig) age; the tightest ages are based on conodonts (table A-1). The oldest conodonts represent the Ro. manitouensis Zone, and are older than any definitively dated faunas known from unit Ol. Younger collections in Oal, however, include those of Mac. dianae Zone age and overlap ages determined for unit Ol. Sparse megafossils in Oal include brachiopods, gastropods, and trilobite fragments (Sainsbury, 1969b); echinoderm debris, calcareous sponge spicules, and possible calcispheres were noted in thin sections. Various types of stromatolites occur locally and form biostromes as much as $5 \mathrm{~m}$ thick (Sainsbury, 1969b; 
Vandervoort, 1985).

Lithologic and fossil data indicate that Oal was deposited in a range of subtidal to supratidal settings within a deepening-upward regime (Dumoulin and Harris, 1994); overall, Oal appears to have formed in somewhat shallower and more agitated water than unit OI. Conodonts in Oal are scarcer and less diverse than in unit Ol, likely because Oal accumulated more rapidly and (or) suffered more terrigenous input. Conodont assemblages in Oal are mainly cosmopolitan but include a few Laurentian (North American) and Siberian endemic forms (Dumoulin and Harris, 1994; Dumoulin and others, 2002; J.E. Repetski, written commun., 2008).

Some rocks presently included in unit OPI are similar in lithofacies, biofacies, and age to Oal (Vandervoort, 1985; Till and Dumoulin, 1994). Unit Oal also correlates well with parts of unit Od in the Nome Complex, the Baird Group (Tailleur and others, 1967; Dumoulin and Harris, 1994) in the western Brooks Range (unit "DOb" of Till and others, 2008b), and the Novi Mountain Formation, lower Telsitna Formation, and related rocks in the Farewell terrane of interior Alaska (Dumoulin and Harris, 1994; Dumoulin and others, 2002). Equivalent to unit "Oal" of Sainsbury (1969a,b, 1972)

\section{UNITS WITH UNCERTAIN AFFINITIES}

Pzl Limestone (Paleozoic) - Intensely deformed limestone that has yielded no fossils but is presumed to be of Paleozoic age (Sainsbury, 1972), exposed in several small outcrops in central Teller quadrangle, northeast of the York Mountains. Equivalent to western part of unit "Pzl" of Sainsbury (1972)

MI Limestone, dolomitic limestone, and marble (Mississippian) - Intensely deformed and recrystallized medium-dark-gray carbonate rocks, locally cherty and intercalated with subordinate fine-grained siliciclastic strata, exposed on westernmost tip of Seward Peninsula (Teller quadrangle; Sainsbury, 1972). Unit has been intruded and locally highly altered by the Cape Mountain granite (unit Ktg) and associated tin-bearing fluids (Steidtmann and Cathcart, 1922). A poorly preserved coral fauna of probable Late Mississippian age was obtained from these rocks; it resembles that found in parts of the Lisburne Group (Schrader, 1902; Bowsher and Dutro, 1957) of northern Alaska (Steidtmann and Cathcart, 1922; W. Sando, unpub. fossil report, 1984). Some authors have correlated rocks of this unit with the Lisburne Group that is exposed north of Seward Peninsula at Cape Lisburne; Grantz and others (1991), for example, included both successions in their Tigara subterrane of the Arctic Alaska terrane. Sainsbury (1972) interpreted these rocks as having been thrust above the slate of the York region (unit OPt of this map). Equivalent to unit "Ml" of Sainsbury (1972)

$\mathrm{Pzgb}$ Metagabbro (Paleozoic) - Dark-green-to black-weathering massive bodies of metagabbro exposed in rubble crop and small blocky cliffs associated with units OPt, OPp, and OPI (Sainsbury, 1969b). Throughout the unit, igneous textures are retained in thin section. In central Teller quadrangle, east of the York Mountains, relict clinopyroxene grains are partially recrystallized to actinolite, but other igneous minerals are completely recrystallized to a metamorphic assemblage of epidote, albite, chlorite, and small amounts of calcite, titanite, opaque, and stilpnomelane. In western Teller quadrangle, igneous minerals are more completely retained but show undulatory extinction and are cut by brittle cracks; metamorphic actinolite and chlorite occur on cracks and grain boundaries on or near clinopyroxene; small amounts of brown hornblende are considered late magmatic. Plagioclase is partially recrystallized to a very fine mat of brownish material, including sericite. Veins and veinlets of sericite and calcite are present in some samples. A U-Pb zircon crystallization age from one of these less recrystallized bodies, northwest of the York Mountains, is $539 \pm 11 \mathrm{Ma}$ (table 3; Amato and others, 2009). A detrital zircon sample collected from unit OPt near the $\mathrm{U}-\mathrm{Pb}$ zircon sample contains a probability distribution peak near this age (J. Toro, written commun., 2006, 2007), and may represent reworking of gabbroic or related volcanic material. Another sample of unit OEt, collected from one of its southernmost exposures along the shoreline, contained a single Ordovician conodont. Metagabbro bodies are mapped near that locality, which raises the possibility that there might be two ages of gabbro in unit OPt: the dated gabbros (earliest Cambrian), and a younger set (Ordovician or younger)

OBI Limestone and dolomitic limestone (Ordovician to Proterozoic) - Light-gray- to grayishorange-weathering, medium-light-gray to medium-dark-gray limestone and dolomitic limestone that occurs widely in western, central, and northern parts of the Teller quadrangle. The 
unit forms low outcrops and extensive areas of rubble and is locally intruded by gabbro (unit Pzgb of this map; Sainsbury, 1972). Most exposures of OPI are fault bounded, but in western Teller quadrangle, it may depositionally overlie unit ORt (Sainsbury, 1969b, 1972). Beds are even to irregular and mostly 2 to $30 \mathrm{~cm}$ thick. Much of the unit is parallel laminated, but crossbedding occurs locally and some intervals are bioturbated. Other sedimentary features include fenestral fabric and intraclast conglomerate with clasts as much as $5 \mathrm{~cm}$ long. Lime mudstone, in part dolomitic and (or) argillaceous, is the main lithology in OPI; quartz silt to very fine sand makes up as much as 20 percent of some samples. Minor to trace amounts of chert, zircon, pyroxene, and antigorite(?) also occur in silty lime mudstone, suggesting that mafic rocks contributed detritus to this unit (Sainsbury, 1969b). Grainstone, composed mainly of intraclasts, peloids and rare bioclasts, is a notable subordinate lithology.

Unit OPI contains rocks of more than one age. Sainsbury (1972) considered much of this unit to be Precambrian, but subsequent paleontological studies indicated that at least some strata are Ordovician. Unit OPI has produced dated fossil assemblages (mostly conodonts) at more than 10 localities (table A-1; T. Carr and T. Hudson, written commun., 1982; Vandervoort, 1985; Till and Dumoulin, 1994; Toro and others, 2006). A few collections consist only of poorly preserved conodonts, chitinozoans, or acrotretid brachiopods that merely indicate broad, mainly Paleozoic age ranges, but several conodont assemblages are tightly dated as early-middle Early Ordovician (table A-1) and correlate well with faunas from units Oal and Ol. The gabbro that intruded OPI, however, is earliest Cambrian (unit Pzgb; Amato and others, 2009), which constrains the age of at least part of the unit to Early Cambrian or older.

Metamorphic grade and degree of deformation vary within OPI. Some samples appear unmetamorphosed and undeformed in thin section, whereas other samples contain layers rich in metamorphic white mica, are recrystallized, and have a phyllitic or schistose fabric. CAI values of conodont collections from this unit are mostly 4-4.5, but are 5 and 6 at several localities (table A-1); these values indicate that host rocks reached temperatures of 190 to $>360{ }^{\circ} \mathrm{C}$ (table A-2). Relations between variations in CAI values, metamorphic textures, and structural level have not been documented.

Lithofacies and biofacies of Ordovician strata in OPI match particularly well with those of unit Oal. Unit OPI also correlates with parts of unit OI, the Baird Group (Tailleur and others, 1967; Dumoulin and Harris, 1994) in the western Brooks Range (unit "DOb" of Till and others, 2008b), and the Novi Mountain Formation, lower Telsitna Formation, and related rocks in the Farewell terrane (Dumoulin and Harris, 1994; Dumoulin and others, 2002). Equivalent to units "pOt" and "pOl” of Sainsbury (1969a), "pOal”, "pOa”, "pOl”, and "pOlu” of Sainsbury (1969b), and "Op€l”, "p€t", "p€ld”, and part of unit "p€l” of Sainsbury (1972)

ORt Sandstone, siltstone, and limestone (Ordovician to Proterozoic) - Gray- to orange-weathering, gray to brown, locally calcareous sandstone to siltstone, interbedded with gray to black mudstone and local limestone, exposed in western Teller quadrangle. Beds are typically $\leq 5$ $\mathrm{cm}$ thick (20 cm maximum). Outcrop features, which include climbing ripples, crossbeds, parallel and convolute laminae, and graded beds, suggest a turbidite origin. Sandstone is very fine to coarse grained; some beds contain black shale fragments 1 to $2 \mathrm{~mm}$ long. Sand and silt clasts are angular to subrounded and consist of quartz, feldspar, sedimentary and metamorphic lithic grains, mica, chlorite, and minor tourmaline and zircon. Limestone is fine grained, ferroan, and contains as much as 10 percent silt to medium-sand-size grains of quartz and feldspar. In thin section, samples of OPt appear recrystallized but only mildly deformed. Sainsbury (1969b, 1972) suggested that OPt depositionally underlies unit OPI; its contact with unit $\mathrm{Ml}$ is a fault.

Unit ORt likely includes rocks of more than one age. The unit was intruded by gabbro (unit Pzgb of this map; Sainsbury, 1972) that at one locality in the northeastern part of the outcrop belt of OPt has been dated as earliest Cambrian (Amato and others, 2009). However, southern exposures of OPt produced a single conodont of middle Early-Late Ordovician age at one site (table A-1; Till and Dumoulin, 1994) and conodont fragments of indeterminate Cambrian-Triassic age at two other sites (table A-1; T. Carr and T. Hudson, written commun., 1982). A detrital zircon sample of sandstone from eastern exposures has a major peak in cumulative probability distribution at $550 \mathrm{Ma}$ and several other notable peaks between 640 and $720 \mathrm{Ma}$ (J. Toro, written commun., 2006, 2007). The 550 Ma peak may include zircons derived from the gabbros (unit Pzgb) or their volcanic equivalents. Unit OPt, 
therefore, is in part Proterozoic (pre-intrusion of gabbros), and in part Ordovician or younger (based on fossil data).

Unit OPt could correlate, at least in part, with Middle Ordovician-Lower Silurian graptolitic argillite and turbidites (Iviagik Group of Martin, 1970) exposed south of Cape Lisburne (Grantz and others, 1983; Moore and others, 1994, 2002; Harris and others, 1995). Metasandstone in the Iviagik Group has a range of compositions (Dumoulin, 2001; Moore and others, 2002) that are broadly similar to those observed in OPt but the metasandstone differs in containing more chert, including grains of radiolarian chert not seen in OPt. Equivalent to parts of "pOs" of Sainsbury (1969b) and "p€s" of Sainsbury (1972)

OEp Phyllite (Ordovician to Proterozoic) - Fine-grained, mainly pelitic and (or) calcareous phyllite exposed in west-central Teller quadrangle. Unit crops out on creeks, weathers gray to grayish-brown, and is layered and locally finely laminated. The phyllitic foliation surface is crenulated. Gray-weathering material is sericite-rich; brown-weathering rocks are calcareous. In thin section, grain size, composition, and oriented lenses of sericite and opaques define foliation. Thin sericitic layers alternate with layers that contain interlocking crystals of calcite that are matrix to disseminated rounded to subrounded plagioclase and quartz grains. Locally, carbonate grains are stained with iron oxide. No fossils have been found, but OPp was intruded by gabbro (unit $\mathrm{P}_{\mathbf{z}} \mathrm{b}$ of this map) that crystallized in the earliest Cambrian (Amato and others, 2009). Unit PZEt may be a more deformed and metamorphosed correlative of ORt. Equivalent to parts of units "pOs" of Sainsbury (1969a, b) and "p€s" of Sainsbury (1972)

\section{GRANTLEY HARBOR FAULT ZONE}

Pzp Phyllite and argillite (Paleozoic) — Phyllite, argillite, and lesser metasiltstone and fine-grained metacarbonate rocks exposed south and north of Grantley Harbor in central Teller quadrangle. Outcrops consist of brownish-orange- to black-weathering, silvery-gray to black, locally carbonaceous phyllite to argillite, with interlayers and lenses of tan to green metasiltstone to semischist and dark gray to black, locally tannish-orange metacarbonate. Lithologies are interlayered on a scale of centimeters, with metacarbonate layers as thick as $1.5 \mathrm{~m}$. These rocks have yielded sparse conodont fragments of indeterminate Ordovician-Triassic age (table A-1; T. Carr and T. Hudson, written commun., 1982, 1984) and contain rare relict bioclasts, including probable recrystallized radiolarians and siliceous sponge spicules, observed in thin section. Unit $\mathrm{z} \mathrm{p}$ in part resembles carbonaceous radiolarian-bearing rocks found in eastern exposures of unit DOx. Equivalent to part of unit "Pzb" of Hannula and others (1995) and parts of unit "p€s" and "p€nc" of Sainsbury (1972)

$\mathrm{PzI}$ Metalimestone (Paleozoic and Proterozoic?) - Thinly layered to laminated, orange-and grayweathering, color-banded, white to dark-gray metalimestone exposed in a small area south of Grantley Harbor in south-central Teller quadrangle. Layers range from a few millimeters to $6 \mathrm{~cm}$ thick and reflect differences in composition and grain size. Darker layers are finer grained, more impure, and contain abundant organic material and white mica, whereas lighter layers are coarser grained and consist mostly of calcite and lesser silt-size quartz grains. The unit has a well-developed cleavage which is axial planar to tight to isoclinal folds, formed at low- or sub-greenschist facies conditions, and a second, lower temperature dissolution cleavage with associated tight folds (Hannula and others, 1995). Calcite-filled tension gashes are common (Hannula and others, 1995). No fossils have been positively identified, although a few forms noted in thin section could be relict bioclasts. Locally, this unit includes interlayers of red-weathering, green phyllite and appears to grade into unit PzEt. Thinly interbedded lime mudstone and argillaceous limestone is the most likely protolith for $\mathrm{Pz} \mathrm{EI}$, which may be a more deformed and (or) metamorphosed correlative of unit Oal and (or) unit OEI. Equivalent to unit "Pzsl" of Hannula and others (1995) and a small part of unit "p€l" of Sainsbury (1972)

PzEt Metasiltstone and phyllite (Paleozoic and Proterozoic?) - Metasiltstone, metasandstone, and phyllite that form a small exposure south of Grantley Harbor in central Teller quadrangle. The unit consists of intercalated grayish-green metasiltstone to medium-grained metasandstone, in layers $1 \mathrm{~cm}$ to $1 \mathrm{~m}$ thick, grayish-green to silver phyllite and silty phyllite, and dark gray to black phyllitic shale. Percentage of these lithologies varies throughout the outcrop belt but metasiltstone and (or) metasandstone generally predominate. Some coarser grained layers appear to be graded, contain parallel laminae, and (or) show local cut-and-fill struc- 
tures; shaly rip-up clasts as much as $4 \mathrm{~cm}$ long occur at several localities. Metasandstone and metasiltstone layers have a semischistose texture and consist mainly of quartz, calcite, and quartz-white mica aggregates (metamorphic lithic clasts?) in a matrix of white mica and chlorite; lesser clast types include feldspar, dolomite, and allanite(?). No fossils constrain the age of the unit, but lithofacies suggest they may be a more deformed equivalent of unit ORt. Equivalent to part of unit " $\mathrm{z}$ b" of Hannula and others (1995) and a small part of unit "p€s" of Sainsbury (1972)

\section{NOME COMPLEX}

\section{LAYERED SEQUENCE}

Pznp Metagabbro and metasediments (Paleozoic?) - Massive hills, tors and rubble piles of metagabbro and poorly exposed metasedimentary rocks on west side of the Kigluaik Mountains. Metagabbro bodies form flat-topped hills generally less than a kilometer across; one body exposed along sea cliffs is $9 \mathrm{~km}$ long. Metasedimentary rocks are poorly exposed and include metagraywacke and tuffaceous metasediments. Original igneous and sedimentary features are preserved. In thin section, metagabbro is coarse grained and partially to completely recrystallized to actinolite, epidote, chlorite, titanite, albite and quartz (Hannula and others, 1995; Till, unpub. data). The metagabbros are geochemically similar to metabasites from units Ocs and DOx (Ayuso and Till, 2007). The geometries of outcrop-scale structures are similar to those in the more completely recrystallized and deformed part of the Nome Complex. Hannula reported three pumpellyite and actinolite bearing samples from northern parts of the unit and one crossite-bearing sample from the central part, which indicates that metamorphic grade increases from northwest to southeast within the unit. The contact between units Pznp and Ocs to the southwest corresponds to the garnet isograd of Hannula and others (1995). Unit Pznp may be equivalent to unit Ocs. Equivalent to unit "Pzmvu" of Hannula and others (1995)

Ds Pelitic schist (Devonian?) - Tors of resistant, well-foliated quartz-rich schist. Pelitic rocks are the dominant lithology; calcareous schist is a minor component. Outcrop appearance of the pelitic schist is diagnostic of the unit, and shows 1- to 2-cm-thick bands of granular interlocking quartz grains interlayered with micaceous schist. In thin section, major minerals include quartz, muscovite, chlorite, chloritoid, and locally graphite, glaucophane and garnet. Quartz-segregation layers parallel foliation and trace intrafolial isoclinal and chevron-style folds axial planar to the foliation. Minor lithologic variation may occur at outcrop scale, typically with relatively thin calc-schist layers in quartz-rich schist.

Four detrital zircon samples were collected; only one yielded sufficient zircons for analysis. The youngest zircon population contains Early to Middle Devonian grains (Till and others, 2006). At least part of the protolith of the unit is Devonian or younger.

Unit thickness is unknown. Typical examples of the unit crop out in northeast Solomon D-5 quadrangle. First described by Smith (1910). Equivalent to unit "p€st" of Sainsbury (1974) and unit "€p€s" of Till and others (1986), and unit "Ds" of Werdon and others (2005a,b) and Newberry and others (2005)

Dcs Pelitic, calcareous, and graphitic schist (Devonian)_Pelitic, calcareous, and graphitic lithologies interlayered on a scale of centimeters to meters, exposed in central Nome and Solomon quadrangles. Interlayering is gradational and intimate. The unit is composed predominantly of pale brown and gray weakly foliated to well-foliated schists dominated by plagioclase, calcite, quartz, white mica, and graphite. In the central Solomon quadrangle, where calcareous lithologies are subordinate to pelitic lithologies, the unit forms smooth rounded hills, or more commonly, is present in valleys and areas of subdued topography. Rarely forms outcrops; usually forms loose rubble on hills or in stream cuts; in low areas unit is covered by tundra. Ridge-top outcrops and ridge-flanking tors are more common in the Nome quadrangle, but not abundant. The unit may be present but unrecognized in exposures of the Nome Complex north of Kigluaik and Bendeleben Mountains.

Pelitic rocks are light to dark gray weathering and contain pale-colored chloritoid, glaucophane or pseudomorphs of chlorite and albite after glaucophane, and in rare cases, garnet; at some localities, micaceous laminae alternate with quartz-rich laminae. Accessory minerals include epidote, clinozoisite, apatite, tourmaline, sphene, graphite, ilmenite, pyrite, rutile, and zircon. Calcareous schist is light to dark brownish-gray and commonly contains plagioclase, 
chloritoid, calcite, some dolomite, and rare garnet. Plagioclase commonly occurs as syn- and post-penetrative deformation metamorphic porphyroblasts. Accessory minerals include apatite, tourmaline, graphite, pyrite, rutile, and zircon. Gray-weathering, plagioclase-rich lithologies are interlayered with orange- or brown-weathering impure marble or calcareous schist in some localities, mica- and graphite-rich schists in other localities. Layers rich in chlorite and albite, with and without white mica and calcite, are generally less than $0.5 \mathrm{~m}$ thick.

The unit includes relatively thin, but widely distributed, layers of light to dark gray or pale orange weathering millimeter-scale color laminated marble. Marbles are slightly impure, most commonly with small concentrations or disseminations of quartz, white mica, and graphite; marbles also can include iron carbonate, iron oxide, and rare sulfide minerals. Less common, but also broadly distributed, are layers typically less than $20 \mathrm{~cm}$ thick of pale tan- to white-weathering metaquartzite with fine laminations defined by minor iron carbonate, iron oxide, and white mica.

Dark-gray- to black-weathering, graphitic metasiliceous rock, locally micaceous, contains millimeter-scale laminae enriched in graphite, white mica, and iron oxide, and occurs in layers meters to tens of meters thick; exposures are generally thinner than the graphitic metasiliceous layers in unit DOx.

In the Nome quadrangle, a dark-gray to black-weathering rock with white millimeterto centimeter-thick lenses, layers, and irregular blobs of polycrystalline quartz forms layers a meter to several meters thick. Matrix to the quartz concentrations is typically rich in white mica, graphite, chlorite, and albite in varying abundances. Many exposures are resistant. Some of the polycrystalline quartz lenses and blobs trace intrafolial isoclinal folds; blobs on fold hinges are more equant. These features and other deformational characteristics of the Nome Complex are consistent with a protolith for Dcs that had quartz-rich alternating with mica-rich layers, although its present appearance is suggestive of a conglomerate. Unit Dcs is equivalent to the "lumpy schist" or unit "pCPzspm" of Bundtzen and others (1994).

A distinctive group of lithologies along the western margin of the unit in the Nome quadrangle coincides with a long, linear resistivity low and magnetic high (Burns and others, 2005a,b). Pale-green- and pale-gray-weathering, locally brown-weathering schists locally display millimeter- to centimeter-thick layers of sugary white quartz. Rocks typically are interlayered concentrations of quartz with lesser iron carbonate and epidote versus white mica, medium-dark colored chloritoid, and locally epidote, iron carbonate, and chlorite. Chloritoid grains may occur in polycrystalline lenses within white mica laminae. Epidote grains contain brown (allanite) cores. Brown-weathering layers are calcareous. This group of lithologies locally contains $\mathrm{Zn}-\mathrm{Pb}$ mineralization. A lens of carbonate clast conglomerate, 10 to $15 \mathrm{~m}$ thick and $\geq 15$ to $20 \mathrm{~m}$ long, sits between this group of distinctive lithologies and the thick pure marbles of unit DOx. The conglomerate is poorly sorted, matrix supported, interlayered with schist; its matrix is calcareous schist that contains abundant quartz and white mica. Clasts are rounded to angular, elongate to disc-shaped, and as much as $75 \mathrm{~cm}$ in maximum diameter. Most are light gray to beige dolostone and medium gray marble.

Many detrital zircon samples contain small populations of Middle and Late Devonian zircons and large populations of early-middle Silurian zircons as well as older populations (Till and others, 2006; Till and others, 2008a). Therefore, much or all of the unit is Devonian or younger. Thickness of unit is greater than $1.2 \mathrm{~km}$.

A distinctive marble forms a small lens within or adjacent to Dcs in the Nome quadrangle. The marble is white to light gray, generally impure (5 to 15 percent quartz, 1 to 5 percent white mica), and typically contains sand- to pebble-size clasts of dark gray to black, organic-rich marble. Most clast-bearing intervals appear to be clast supported and some may be graded. Clasts are rounded to angular in shape, commonly laminated, and generally $\leq 2 \mathrm{~cm}$ in diameter; a few clasts may be as much as $12 \mathrm{~cm}$ long. The clastbearing marble produced conodonts with CAI values of 5 at two localities (table A-1). One collection yielded a single element of Silurian(?) through Triassic age. The other collection, also a single conodont, is an Sb element of late Permian through Triassic (likely Triassic) age. Three possible scenarios that explain the presence of a Triassic marble in the otherwise Devonian and older Nome Complex include: (1) contamination of the conodont sample; (2) pre-metamorphic fault juxtaposition of Triassic and older rocks; and (3) a pre-metamorphic unconformable relation between Triassic and older rocks. The CAI value of this conodont is consistent with that of other Nome Complex rocks, and no rocks that could have produced 
such contamination (that is, rocks of known Permian or Triassic age and high thermal level) were being processed in the laboratory at the time the Seward Peninsula sample was run (A. Harris, written commun., 2005). Thus, the clast-bearing (Triassic?) marble was juxtaposed with Dcs before or during Jurassic metamorphism or may be a rare remnant of rocks that sat unconformably atop protoliths of the Nome Complex before those protoliths were metamorphosed. Because of the uncertainties in the origin of this marble and its uniqueness, we choose not extend the protolith age of the Nome Complex to Triassic

DOx Mixed marble, graphitic metasiliceous rock, and schist (Devonian to Ordovician)-Inter-

layered pure and impure marble, graphitic metasiliceous rock, pelitic schist, calc-schist, and mafic schist. Gray- and orange-weathering marble and dark gray-black-weathering graphitic metasiliceous rock are the most common lithologies in the unit, which is dominated locally by one or the other. Gray-weathering pure marble forms rounded ridgelines that extend along strike for several kilometers, and rounded hills of slabby, black graphitic metasiliceous rock can be recognized from great distances. The unit is defined by its position structurally below the Casadepaga schist (unit Ocs). Good exposures are rare; minor lithologies generally do not crop out. Lithologies thicken and thin along strike on a scale of kilometers, a feature which may be depositional as well as structural.

In western Solomon quadrangle and Nome quadrangle, there is a consistent general stacking pattern of lithologies within DOx. The structurally upper part of the unit is composed of mixed schist and marble, including pelitic schist, gray marble, orange-weathering impure marble, black schistose marble, and black metasiliceous rock; these lithologies are interlayered on a scale of meters and decameters. The uppermost lithology is commonly an orange-weathering marble that varies from pure to impure on a scale of meters. Impurities include chlorite, quartz, tremolite, and albite; impure layers also include intraclasts, most $3 \mathrm{~cm}$ or less in diameter. One of the pure marble layers yielded Ordovician conodonts (see below). Other impure marbles in the upper part of DOx also contain intraclasts. Total thickness of the mixed schist and marble sequence varies from $250 \mathrm{~m}$ to over $2 \mathrm{~km}$. The structurally lower parts of the unit are dominated by gray marble or black metasiliceous rock. Where the gray marble is dominant, it reaches thicknesses of $1-2 \mathrm{~km}$ and contains minor thin (less than $50 \mathrm{~m}$ ) layers of metaquartzite, pelitic schist, and chlorite-albite schist. Where the black metasiliceous rock is dominant, it reaches thicknesses of around $500 \mathrm{~m}$ and is underlain by 10-30 m of gray marble interlayered with thin bands of pelitic schist.

Metabasites are found in both the mixed schist and marble sequence and within the thick, unit-dominating gray marble and black metasiliceous rock. These mafic rocks are boudins or layers of glaucophane-, epidote-, and garnet-bearing metabasite, or chlorite-, albite-, actinolite-bearing metabasite similar to those found in the Casadepaga schist. Within DOx, they occur in greatest volume south of Salmon Lake near the boundary between the Nome and Solomon quadrangles.

The gray-weathering pure marble is pale gray to white on the fresh surface, and composed of coarse crystalline calcite. The graphitic metasiliceous rock is generally homogeneous, dark-gray or black, and compositionally limited to quartz, graphite, and very small amounts of white mica, albite, and chlorite. Graphite may be present in sufficient quantities to rub off on the hands. Locally a centimeter-thick banding of dark gray-black quartz-graphite schist and gray-black quartz-graphite-calcite schist are found.

In Nome quadrangle, DOx contains several small rubble patches of carbonate conglomerate, as well as rubble and outcrops of light gray dolostone, locally mottled with orange, pink, or light brown, that retain relict sedimentary features. Conglomerate is matrix supported and contains rounded to angular clasts, as much as $8 \mathrm{~cm}$ long, of pale-orange to medium-gray dolostone; at one locality, the unit contains subordinate clasts of marble and quartz-white mica schist. The matrix is beige to orange pink or light brown dolomite with lesser quartz and white mica. Relict textures, seen in conglomerate clasts and in mottled dolostone rubble, include coated grains, crinoid ossicles, and possible brachiopod fragments.

In northwestern Solomon quadrangle, DOx contains an interval of dolostone-clast conglomerate as much as 100 to $200 \mathrm{~m}$ thick and $480 \mathrm{~m}$ in lateral extent. The conglomerate ranges from matrix-supported ( 1 to 10 percent clasts) to clast-supported ( $>80$ percent clasts) and contains interlayers and (or) lenses of clast-free schist and dolostone. Clasts are rounded to irregular; most have a flattened, ovoidal shape but some are rod-like. Sorting is 
poor; clasts range from a few millimeters to $70 \mathrm{~cm}$ in maximum dimension. Some clasts are finely laminated. Most clasts consist of light-gray- to rusty-weathering, very light gray, finegrained ferric dolostone with minor amounts of quartz, white mica, and calcite. About 1 to 5 percent of clasts are medium light gray marble. The conglomerate matrix is quartz schist that also contains white mica, dolomite, chlorite, epidote, and chloritoid. A less extensive (several meters thick by $10 \mathrm{~m}$ long) but otherwise similar lens of dolostone-clast conglomerate occurs in unit Ocs in the Nome quadrangle. The dolostone clasts at both localities resemble, and may have been derived from, dolostone equivalent to that in unit $€ d$.

The age range of DOx is not strictly known. Conodonts of Ordovician age were obtained from a pure layer in the impure marble at the structural top of DOx (in the Solomon quadrangle). Marble in the Nome quadrangle produced conodonts of early Paleozoic age (table A-1, T. Carr and T. Hudson, written commun., 1982, 1984). Recrystallized radiolarians collected in northern Darby Mountains in banded calcite-bearing graphitic metasiliceous rock are of probable pre-Devonian age (B.K. Holdsworth, written commun., 1985).

In the Teller quadrangle, part of the unit (shown with the diagonal line overlay) is distinct in age and lithology. Dolostone, dolomitic marble, and marble form an elongate belt, extending for almost $40 \mathrm{~km}$, in the westernmost part of DOx in eastern Teller quadrangle; only the southern half of the belt has been examined. The unit forms rubble-covered hills; outcrops are rare. Dolostone is medium gray to dark gray and weathers light to medium gray, very pale orange, or dark yellow brown. Sedimentary structures include millimeter- to centimeter-scale parallel lamination and lesser color mottling that likely reflects bioturbation. Intraclasts (maximum $1 \mathrm{~cm}$ in diameter) and millimeter-scale burrows occur locally. In thin section, dolostone is mostly finely crystalline and non-ferroan; some samples contain minor amounts of fine-grained quartz and white mica, or rare clasts (bioclasts?). Marble is white to grayish black and has few relict sedimentary features other than locally well-developed parallel lamination. Conodonts of late Silurian-Devonian age have been recovered from two localities; a third locality produced a fauna of Silurian (late Llandovery-Ludlow) age (table A-1). Sedimentary structures and conodont biofacies suggest a warm, shallow-water depositional setting. Faunal and lithofacies data indicate that these rocks may correlate, at least in part, with unit Sd in the Nome Complex. Correlation with units Ddm and SOdl and SOul (York terrane) is also possible, although these units contain more abundant megafossils than DOx with diagonal line overlay. Shallow-water Silurian rocks also occur widely in the Brooks Range. Units that contain such strata and could correlate, at least in part, with DOx (overlay) include units "DOb" (Baird Group), "DOc", and "DSc" of Till and others (2008b); Silurian lithofacies in unit "DSc" are an especially good match. Unit DOx (with overlay pattern) is equivalent to parts of units " $\mathrm{P} \mathbf{z m}$ " and "p€n" of Sainsbury (1972).

Three detrital zircon samples have been collected from DOx in southern Seward Peninsula. One yielded largely Neoproterozoic zircons, another yielded zircon populations as young as Silurian, and the third yielded a robust population of Middle and Early Devonian zircons (Amato, written commun., 2008). Apparently, at least part of DOx must be Devonian or younger.

On the eastern edge of the map area, on the boundary of Norton Bay and Candle quadrangles, exposures of metasedimentary rocks include calcareous, pelitic, and quartz-rich lithologies. These rocks have not been studied in detail; some may ultimately prove to have histories separate from the Nome Complex. These rocks are equivalent to units "PzPus" and "MzPzq" of Patton and others (2005).

Unit DOx is between 0.8 to $1.5 \mathrm{~km}$ thick, and best exposed in eastern Solomon D-5 quadrangle and in east-central Solomon D-6 quadrangle. The unit includes parts of units "p€s" and "slate of the York region" of Sainsbury (1974)

Dg Granitic orthogneiss (Devonian) - Fine-grained, very light gray to orange-weathering, wellfoliated, white to light tan schist of granitic to tonalitic composition that forms the rounded, frost-riven slopes of Kiwalik Mountain and one small body in northern Darby Mountains. Commonly forms weathered boulders $0.5-1 \mathrm{~m}$ across. Crops out rarely; where foliation can be measured, it is parallel to the foliation in the surrounding schist. Contact crosses lithologic layering in surrounding schist. Layers and boudins of the orthogneiss which have chilled margins are commonly found in country rock close to the contact. Quartz, albite, $\mathrm{K}$-feldspar, and white mica are the most common constituents. Accessory minerals include 
biotite, epidote, fluorite, magnetite and calcite. The unit yielded a U-Pb zircon age of $391 \pm 3$ Ma (J. Aleinikoff, written commun., 2005; Till and others, 2006). A small body associated with unit DOx in the northern Darby Mountains yielded an age of $390 \pm 4$ Ma (Toro, written commun., 2006); a foliated body with a similar age was found in the high-grade metamorphic rocks of Bendeleben Mountains (Gottlieb and Amato, 2008). Middle Devonian granitic orthogneiss (also approximately $390 \mathrm{Ma}$ ) is known in eastern Brooks Range in a metamorphic belt with a similar history to the Nome Complex (Aleinikoff and others, 1993; Moore and others, 1997). Granitic orthogneiss with similar, but less well-defined age, is present in central Brooks Range and southern Ruby geanticline (Toro and others, 2002; Patton and others, 1987; Roeske and others, 1995)

Df Felsic schist (Devonian) - Light-orange to light-green-weathering, fine- to coarse-grained quartz-feldspar white mica schist. Crops out on the southwest flank of Kiwalik Mountain as platey rubble-crop of millimeter-scale laminated, very fine grained schist. Rarely, accessory black tourmaline lies in plane of foliation. Stream gravels along strike to the northwest of the rubble crop include a rock which has the appearance of a flattened matrix-supported conglomerate or fragmental volcanic, composed of clasts and matrix of the major minerals listed above. Clasts show greatly varying grain size and internal textures. U-Pb zircon age from laminated schist on the flank of Kiwalik Mountain is $391 \pm 5 \mathrm{Ma}$ (J. Aleinikoff, written commun., 2005; Till and others, 2006); the fact that the schist contains a single zircon population supports an igneous protolith for the unit. The contact between Df and other parts of the Nome Complex may be a fault. Two metafelsites of essentially identical age were identified in eastern Brooks Range, where metafelsites occur in sections of rocks less metamorphosed than the Nome Complex (Aleinikoff and others, 1993; Moore and others, 1997)

Ocs Casadepaga Schist (Ordovician) - Light-green, silvery green and greenish-brown mafic, feldspathic, and calcareous schist. Typically occurs as frost-riven slabs and flakes that underlie rounded hills and dark-greenish-black tors and rubble piles several meters across. Tors of metabasite, abundant plagioclase porphyroblasts in dark-green, chlorite-rich schist, and the quartz-poor nature of the rocks are characteristic of this unit. The most common lithologies are dominated by components of mafic, feldspathic, and calcareous composition that are intermixed and interlayered on a scale of tens of centimeters; the layering may occur in repetitive couplets.

Medium- to pale-grayish-green-weathering pelitic schists are common. Plagioclase, chlorite, white mica, and quartz in subequal amounts dominate; epidote, carbonate, and glaucophane (or pseudomorphs of chlorite and plagioclase after glaucophane) are typical. Titanite (sphene), rutile, and sulfides are present in minor amounts. Based on major element chemistry, the protoliths were shales and graywackes (Werdon and others, 2005a). Carbonate-rich schists or layers are typically buff or pale brown weathering and tend to be more recessive in outcrop than other lithologies. Carbonate layers are rare and thin and include both pure and impure varieties; they weather pale brown, black, or gray. Dark-greenweathering schists are rich in chlorite, epidote, actinolite, and plagioclase, and represent metamorphosed mafic material. Dark-green-weathering chlorite-rich schists spotted with white equant plagioclase grains typically contain few to no calcium-bearing phases. These are probably mafic rocks that were altered or weathered previous to metamorphism.

Boudins, lenses and layers of fine- to coarse-grained, massive metabasite comprise the greenish-black tors. In thin section these rocks are found to be composed of glaucophane, actinolite, chlorite, epidote, garnet, albite, white mica, titanite, and locally quartz, Fecarbonate, pyroxene, and barroisite. Coarser grained varieties have textures suggestive of a coarse-grained gabbroic protolith. Mafic schist layers in the surrounding rocks have mineral assemblages similar to the metabasite pods. The metabasites comprise two compositional groups (Werdon and others, 2005a,c). One group has weakly developed arc-like signatures (for example, slight $\mathrm{Nb}$ depletion in spidergrams) reflecting crustal contamination; the second group exhibits features associated with enriched mantle (E-MORB) and alkaline intercontinental rifts (no Nb depletion, small positive Ti anomalies in spidergrams) (Ayuso and Till, 2007). Metabasites from unit DOx fall into the same two compositional groups. The chemical characteristics are thought to indicate a tectonic setting related to the early stages of continental, rift-related magmatism (Ayuso and Till, 2007).

In western Solomon quadrangle, the contact between Ocs and the overlying impure marble unit (Oim) is exposed. Near the contact, on all sides of a synform cored by Oim, a 
thin (few meters - tens of meters) layer of black weathering, platey, fine grained and finely laminated quartz-graphite schist is present. The amount of graphite in the rock is variable, though it is always black-weathering; thin laminae of lenses (mm- to cm-scale) that are more quartz-rich are common. Graphite is present as fine disseminated material in the quartz-rich matrix, as well as in lozenges several millimeters across. White mica is disseminated and minor. Semi-quantitative spectrographic analyses of a few samples from this layer show elevated values of Mo, V, Ag, and Zn (B. Gamble, written commun., 1985). Thin layers of mafic schist separate the graphitic layer from the overlying impure marble.

No direct evidence exists for the depositional age of Ocs. Seven detrital zircon samples collected from widely distributed parts of the unit contain very similar grain populations. Most grains fall into the range of 600-700 Ma; several samples contain small populations of Ordovician or Cambrian grains (Amato and others, 2003a; Till and others, 2006; 2008a). Depositional age of the unit must be younger than $600 \mathrm{Ma}$ (latter part of the Neoproterozoic), and is likely Ordovician or younger. Werdon and others (2005a) considered the unit to be Cambrian in age, based on an $\mathrm{Rb}-\mathrm{Sr}$ isochron. The samples included in the isochron are a mix of mafic and pelitic rocks, so their assumption that the samples shared the same initial strontium isotopic composition is likely not correct; the isochron represents a mixing line between mafic and sedimentary protoliths.

Unit Ocs is assigned an Ordovician age based on detrital zircon geochronology and on the occurrence in both this and the impure marble unit (Oim) of both metabasite schist layers and unfoliated metabasite pods. The protoliths of both units apparently contained pyroclastic or redeposited mafic material as well as intrusive mafic rocks. Metabasite layers indicate that production of mafic material was at latest syn-depositional - not simply postdepositional. We postulate that units Oim and Ocs were formed in the same basin. Because the impure marble unit yielded Early through Middle Ordovician conodonts, we believe that basin was formed during the Ordovician.

The unit is 0.6 to $1.6 \mathrm{~km}$ thick and is best exposed in southeastern Solomon D-5 quadrangle, north of the Nome-Council road; in central Solomon D-5 quadrangle; and in eastcentral Solomon D-6 quadrangle. The Casadepaga schist was named and first described by Smith (1910). Partially equivalent to the "slate of the York region" of Sainsbury (1974), and unit "p€qms" of Miller and others (1972); equivalent to unit "Ocs" of Till and others (1986) albite-bearing calcite marble that underlies rounded hills. Rare outcrops show well-foliated impure marble to calcareous schist. Impurities are most commonly chlorite and albite. Lenses (up to a meter across) and fine layers of chlorite and albite are diagnostic of the unit, and trace foliation and folds. Chlorite-albite lenses and layers are more abundant near the base of the unit; pods of fine-grained metabasite are also more common in the lower part of the unit. The pods can be recognized in the field as piles of massive, medium-gray rubble several meters across; one is $0.5 \mathrm{~km}$ across. Intraclasts occur in some exposures and are typically composed of black calcite and no more than $4 \mathrm{~cm}$ in diameter. Most commonly they are a minor component of the rock, but locally are concentrated in centimeters-thick layers. In rare instances the unit may include layers of pure marble or orange-weathering dark-gray dolostone. The unit is a minimum of $1.2 \mathrm{~km}$ thick. Conodonts of Early through Middle Ordovician age have been obtained from a dolostone lens in the upper part of the unit in Solomon D-6 quadrangle (84ATi281, table A-1). Excellent exposures of the unit can be found in central Solomon D-6 quadrangle. Equivalent to units "p€sm" of Miller and others (1972); "p€l" of Sainsbury (1974); and "Oim" and "Pzim" of Till and others (1986). In western Solomon quadrangle, the contact of Oim with underlying unit Ocs is marked by a lens of graphitic siliceous rock a few meters thick. Outcrops are black. Quartz and graphite vary in relative concentration, and yield a finely laminated appearance. Fine white mica and sulfide minerals are present in minor amounts. Semi-quantitative spectrographic analysis of these rocks shows they contain elevated amounts of Mo, Ag, Zn, and V

En Metagranitic rocks (Late Proterozoic) - Pale-gray to pale-greenish-tan, locally green-weathering rubble crop and outcrop of small granitic, granodioritic, and tonalitic orthogneiss bodies. Weakly foliated to well-foliated, fine- to coarse-grained, with foliation defined by weak to strong alignment of micas. Coarsest grained varieties may contain lozenge-shaped feldspar grains and thin, millimeter-thick lenses of quartz that also parallel foliation. Plagioclase, quartz, \pm microcline are dominant phases; chlorite, biotite, and white mica are minor 
phases, and are associated with epidote, garnet, and calcite at some localities. Accessory phases include opaque oxides, zircon, apatite, allanite, and titanite. Phengitic white mica compositions in microcline-bearing orthogneiss bodies are consistent with crystallization at blueschist-facies conditions (Evans and Patrick, 1987). In outcrop, foliation parallels surrounding schists of the Nome Complex; the metagranitic rocks were apparently folded in with metasedimentary rocks of the Nome Complex during the Mesozoic. Detrital zircons from metasedimentary rocks of unit Ocs collected immediately adjacent to a body of $\mathrm{En}$ in east-central Nome quadrangle include a significant 600-Ma population, younger than the metagranitic rock (669 \pm 5 Ma, table 3; locality 3, sh. 2) (Till and others, 2006). Late Proterozoic intrusive age based on several $\mathrm{U}-\mathrm{Pb}$ zircon analyses that range from approximately 665 to 685 Ma (including errors) (table 3; Patrick and McClelland, 1995; Amato and Wright, 1998; Till and others, 2006). Equivalent to parts of unit "pCPzg" of Bundtzen and others (1994) and unit "pCdog” and parts of unit "pCPzuog” of Amato and Miller (2004)

\section{SCATTERED METACARBONATE ROCKS}

Pzm Marble, undivided (Paleozoic) - Generally light-gray-weathering, white to medium-gray, medium to coarsely crystalline marble that forms rubble-covered hills and small outcrops that are widely but sparsely distributed through the map area. Marble is dominantly pure, but locally contains as much as 10 percent quartz, white mica, and (or) albite. At several localities in the western Bendeleben and Solomon quadrangles, Pzm contains conodonts, stromatoporoids and (or) colonial and rugose corals of Ordovician through Devonian or Silurian to Devonian age; combined age constraints from megafossils and microfossils at one locality suggest an age of Middle Devonian (table A-1; Till and others, 1986). Unit Pzm likely includes rocks of several different ages. It correlates at least in part with Ddm but lacks the lithologic features diagnostic of that unit; some parts of Pzm may be as old as Ordovician (table A-1). Occurrences that have yielded no fossils are assumed to be Paleozoic based on physical proximity to strata of known Paleozoic age. The relation of Pzm to rocks of the Nome Complex is uncertain; it is most commonly spatially associated with unit Ds. Equivalent to unit "Pzm" of Till and others (1986)

Pzd Dolostone, undivided (Paleozoic) - Generally light-colored, fine-grained, featureless dolostone that forms rubble-covered hills sparsely distributed through the map area. This unit likely includes rocks of several ages. Conodont faunas, obtained at seven localities, are mostly long ranging but one collection, in eastern Bendeleben quadrangle, may be Early Mississippian; another, in northwestern Solomon quadrangle, is middle Silurian-Early Devonian; and a third, in western Candle quadrangle, could be Ordovician (table A-1; Till and others, 1986). Occurrences that lack fossils are assumed to be Paleozoic based on physical proximity to strata of known Paleozoic age. Some rocks mapped as Pzd at Cape Deceit in the Kotzebue quadrangle may be part of unit DObm (T. Ryherd, written commun., 1985; Ryherd and Paris, 1985). Unit Pzd may also include strata correlative with units $€ d, \mathrm{Od}, \mathrm{Sd}$, and (or) Ddm that lack lithologic or faunal features diagnostic of these units. The relation of $P_{z} d$ to rocks of the Nome Complex is uncertain. Equivalent to unit " $\mathrm{Pzd}$ " of Till and others (1986), and, in Candle and Norton Bay quadrangles, to part of "Pzcs" of Patton and others (2005)

Pzmm Marble of the Moon Mountains (Paleozoic) - Pale-gray- to white-weathering, coarsely crystalline calcite marble exposed only in western Nome quadrangle, in an area informally called the Moon Mountains (sh. 2) due to lack of vegetation. The marble has a layered appearance due to variations in grain size; layering is folded. Folds are cut by biotite-hornblende granitic dikes and lesser tourmaline-bearing pegmatites (see unit Kds for ages); gossan is spatially associated with the dikes. Overall large grain size of calcite in the marble is larger than typically found in unit Pzm

Ddm Dolostone, metalimestone, and marble (Devonian)-Medium- to dark-gray-weathering, dark-gray to black dolostone, metalimestone and marble, with minor associated chert, that typically weathers to fist-sized rubble but forms outcrops along river banks or sea cliffs. Unit Ddm is widely but sparsely distributed through the map area; it crops out in the northwestern and eastern Bendeleben quadrangle and the central and eastern Solomon quadrangle; it is best exposed in sea cliffs in the Solomon $\mathrm{C}-1$ quadrangle. Outcrops are not foliated, but are strongly fractured, commonly brecciated, and may be veined with coarse-crystalline calcite or dolomite. Unit Ddm consists of fine-grained, mostly non-ferroan or slightly ferroan dolomite and subordinate fine- to coarse-crystalline calcite. Dolostone is the dominant lithology 
in eastern exposures; metalimestone and marble predominate in western and central exposures. Relict sedimentary structures include zebra dolomite, fenestral fabric, and millimeterscale (algal?) laminations. Thin section textures, where not obscured by recrystallization and dolomitization, are bioclastic and peloidal packstones and wackestones. Early to earliest Late Devonian conodonts have been found in 20 collections; tightest ages are earliest Emsian and latest Emsian-earliest Eifelian (table A-1). A megafauna of late Early, Middle, and early Late Devonian age consists of tabular and rugose corals, stromatoporoids, brachiopods, and rare bryozoans. Megafauna, microfauna, and sedimentary features all denote a warm, relatively shallow water depositional setting. Age and spatial relations suggest that Ddm may have been unconformably deposited on older parts of the Nome Complex, specifically units DOx and DEbm. Lithofacies and faunal data indicate that Ddm correlates well with the youngest strata in the Baird Group (Tailleur and others, 1967; Dumoulin and Harris, 1994) and related rocks in western and central Brooks Range (units "DOb" and "DOc" of Till and others, 2008b) and may also correlate with the Beaucoup Formation (Dutro and others, 1979) and related rocks found throughout the Brooks Range (units "Dl" and "Dmu" of Till and others, 2008b). Equivalent to unit "Ddm" of Till and others (1986) and partly equivalent to unit "Ddl" of Miller and others (1972)

Sd Dolostone (Silurian) - Light-gray- to tan-weathering, light- to dark-gray, fine-grained, ferroan dolostone that forms two small rubble-covered hills, one in southeastern Bendeleben quadrangle and the other in southeastern Solomon quadrangle. At the northern locality, the main lithology occurs with lesser amounts of black dolostone and black marble. Color mottling, likely due to bioturbation, is notable at the southern occurrence. Other features of unit include possible fenestral fabric and relict bioclasts. Gray dolostone at both localities yielded conodont faunas of middle-late Silurian age (table A-1). Sedimentary structures and conodont biofacies indicate a shallow, warm-water depositional environment. Several other lithologically similar dolostones in southeastern Bendeleben and northeastern Solomon quadrangles contain Silurian-Early Devonian conodonts; these occurrences are presently mapped as unit $P_{\mathbf{z}}$ d but may, at least in part, belong to Sd. Shallow-water Silurian strata that correlate, at least in part, with Sd include units DOx (overlay) in the Nome Complex, SOdl and SOul in the York terrane, and the Baird Group (Tailleur and others, 1967; Dumoulin and Harris, 1994) and related units in the western and central Brooks Range (units "DOb" and "DOc" of Till and others, 2008b). Equivalent to unit "Sd" (northern locality) and part of unit "Pzd" (southern locality) of Till and others (1986)

Od Dolostone (Ordovician) - Light-gray- to pink- to tan-weathering, gray to tan dolostone that forms small areas of rubble crop in tundra and local cliffs along river banks. Unit is best exposed along several rivers in northeastern Bendeleben quadrangle, but also crops out at isolated localities in northwestern and southeastern Bendeleben quadrangle and northwestern Solomon quadrangle. Depositional relations between Od and other units are nowhere preserved, but map patterns suggest possible associations with units Oim and Ddm. Unit Od consists of fine-grained, mostly non-ferroan dolomite. Relict sedimentary features include: distinct color-mottling, reflecting an original partly bioturbated fabric; zebra dolomite, suggestive of evaporitic supratidal conditions; fenestral fabric, which generally occurs in tidal flat or shallow subtidal environments; and probable oncolites, which also indicate a shallowwater depositional environment. Conodont faunas represent at least three distinct ages: two discrete intervals in the Early Ordovician, and early to middle Middle Ordovician (table A-1). Most of the assemblages represent shallow to very shallow, warm-water biofacies, but one collection of middle to late Early Ordovician age from the Bendeleben D-2 quadrangle denotes a cooler and (or) deeper water setting (table A-1). A single collection of poorly preserved corals has also been obtained (Till and others, 1986). Most conodonts in Od are cosmopolitan forms, but Siberian and Laurentian (North American) endemics occur in a few collections (Dumoulin and others, 2002). The older (Early Ordovician) part of Od correlates with much of units Oal, OI, and OPI in the York terrane; Middle Ordovician strata in Od are coeval with, but represent shallower water facies than, unit Ols in the York terrane. Od also correlates well in age and lithology with Early and Middle Ordovician rocks of the Baird Group (Tailleur and others, 1967; Dumoulin and Harris, 1994) in the western Brooks Range (unit "DOb" of Till and others, 2008b). Od strata that contain cooler and (or) deeper water biofacies resemble coeval deeper water rocks in unit "OEc" (Till and others, 2008b) in the Baird Mountains quadrangle. Equivalent to unit "Od" of Till and others (1986) 
Dolostone (Cambrian) - Gray- to orange-weathering, light-gray or medium-gray to pinkishorange dolostone that forms hilltop rubble patches and subcrop on several small knobs in the northwestern Solomon quadrangle. The dolostone is non-ferroan to moderately ferroan and locally contains a few percent quartz and white mica. Structurally underlying the dolostone is a section of schist and marble several tens of meters thick. The upper third consists of quartz-white mica schist and chloritic marble; the lower two thirds is mostly marble containing about 10 percent quartz, white mica, and chlorite. The orange-weathering dolostone contains lapworthellids (table A-1), a phosphatic microfossil indicative of Early (to possible early Middle) Cambrian age and a shallow-water depositional environment. Unit €d correlates precisely with the oldest part of unit $\mathrm{DEbm}$, which also contains lapworthellids, and may correlate with part of unit "OBc" (Till and others, 2008b) in the western Brooks Range. Equivalent to unit " $€ d$ " of Till and others (1986)

\section{METATURBIDITES}

D€bm Black marble (Devonian to Cambrian) - Dark-gray to black marble and subordinate fissile impure marble, calcareous schist, and mafic schist that crops out in eastern Solomon and western Norton Bay quadrangles. Unit is best exposed in sea cliffs along Norton Bay and forms rubble covered hills inland. Marble layers are 1 to $20 \mathrm{~cm}$ thick, with rhythmic alternations of purer, coarse-crystalline and more impure, fine-crystalline layers. Common green-weathering mafic dikes, sills, and plugs, 0.5 to $2 \mathrm{~m}$ across, intrude the carbonate strata; preserved contact metamorphic effects include bleached carbonate rocks and albite-, chlorite-, epidote- and tourmaline-bearing skarn assemblages. Mafic rocks consist of finegrained chlorite, actinolite, albite, and white mica; glaucophane inclusions are found in the albite. Commonly, mafic minerals form layers and are disseminated in the fine crystalline carbonate rock, suggesting that some mafic volcanism accompanied deposition of the carbonate strata. All of the mafic volcanic rocks were affected by regional metamorphism, as were the carbonate rocks. Marble protoliths were likely carbonate turbidites and periplatform ooze.

Seven conodont faunas were obtained from six localities in DEbm (table A-1). Two faunas are middle to early late Silurian (Wenlock-Ludlow), one is middle Early Devonian (Siegenian), and one is late Silurian to Early Devonian. Two faunas from westernmost exposures of DEbm are considerably older: one middle Early through Late Ordovician and the other Early Cambrian. Thus, there is a gap of over 100 million years between the oldest and youngest faunas. At least three explanations can be invoked for this faunal distribution. If all conodont collections represent depositional ages, then the unit may represent two episodes of deposition of lithologically similar material — one Early Cambrian, one Late OrdovicianEarly Devonian, separated by a long interval of non-deposition. Or, deposition may have extended more or less continuously from Cambrian into Devonian time - present fossil collections from D€bm are few and future collections may eliminate the apparent hiatus. Alternately, some or all of the conodont collections could be reworked, and the depositional age of the entire unit could be late Silurian-Early Devonian or younger. In this case, the western faunas would represent material eroded from an older (Cambrian and Ordovician) carbonate platform source; the eastern faunas could represent erosion from a younger source or faunas contemporaneous with deposition.

Unit D€bm may be a more deformed equivalent of unit DObm, and it is intercalated with, and possibly a facies equivalent of, unit D€ks. It is lithologically similar to, and may be partly coeval with, Silurian carbonate and siliciclastic turbidites in the west-central Brooks Range (unit "Spl" of Till and others, 2008b). The easternmost exposures of D€bm include some outcrops of unit Ddm that are too small to be mapped separately. Equivalent to unit "D€bm" of Till and others (1986), and partly equivalent to unit "Dld" of Miller and others (1972) and units "Pzcs", "PZPus", and "PZEss" of Patton and others (2005)

D€ks Calcareous schist of Kwiniuk Mountain (Devonian to Cambrian) - Dark-brownish-gray, rustspotted, well-foliated, medium-grained schist composed predominantly of quartz, calcite, white mica, chlorite, plagioclase, and graphite. Locally shows millimeter-scale dark/light layering. Rusted spots (weathered iron carbonate?) up to $0.5 \mathrm{~cm}$ across are locally abundant. Fresh surfaces are gray. Interlayered on a meter to kilometer scale with units DObm and DEbm; age assigned to this unit based on that intimate relation. On Kotzebue Sound, unit is exposed in beach cliffs at Sullivan Bluffs (15 km west of Cape Deceit), where it shows relict 
crossbedding and graded bedding, and contains abundant pyrite. Equivalent to unit "D€ks" of Till and others (1986)

DObm Black metalimestone and marble (Devonian to Ordovician) — Dark-gray to black metalimestone and marble and subordinate dolostone exposed on sea cliffs on Kotzebue Sound. Rocks weather gray to yellowish-brown, commonly have fissile partings, and are well layered. Layers range from 2 to $50 \mathrm{~cm}$ thick, with rhythmic alternation of thicker, coarsecrystalline and thinner, fine-crystalline layers. Relict sedimentary structures include graded bedding, flame structures, loaded bed bottoms, channelized beds, and imbricated rip-up clasts. Three kilometers west of Cape Deceit, a 15- to 20-m-thick interval of dominantly matrix-supported carbonate breccia, with rounded and angular clasts as much as $5 \mathrm{~m}$ in diameter, occurs in the section, as well as thinner $(\leq 1 \mathrm{~m}$ thick) intervals of carbonate-clast breccia. Local solution collapse features occur, and dedolomitization textures were seen in thin sections. Subordinate argillite, phyllite, and radiolarian chert are found about $2.4 \mathrm{~km}$ west of Cape Deceit; quartz-graphite schist and impure marble (containing as much as 20\% graphite, quartz, albite, and white mica) are abundant in the western exposures.

Unit DObm has yielded tightly dated fossil collections of Middle Ordovician through late Silurian age and some longer ranging collections that could be as young as Devonian (table A-1; Ryherd and Paris, 1987). The argillite-dominated interval west of Cape Deceit contains abundant Middle and Late Ordovician graptolite assemblages as well as Ordovician conodonts (Ryherd and Paris, 1987; Harris and others, 1995; Ryherd and others, 1995; Dumoulin and others, 2002). Higher in the unit, a continuous section of allodapic carbonate rocks, at least several hundred meters thick, produced a middle to late Silurian (Wenlock to Ludlow) conodont succession (table A-1; Dumoulin and others, 2002). Several conodont collections from eastern exposures of the unit could be as young as Devonian (table A-1). Well-layered metalimestone containing redeposited(?) rugose and colonial corals of Middle to Late Devonian age have been described from Willow Bay, $20 \mathrm{~km}$ east of Cape Deceit (Kotzebue A-1 quadrangle); these rocks may be part of DObm (T. Ryherd, written commun., 1985).

Two small gabbroic plugs intrude DObm west of Cape Deceit. The plugs show relict ophitic textures and are partially recrystallized to a low-grade metamorphic assemblage of actinolite, epidote, and garnet. CAI values of conodont assemblages in this unit range from 5.5-7 (table A-1) and may reflect the presence of hydrothermal fluids.

Unit DObm represents periplatform ooze, turbidites, and debris flow deposits derived from a carbonate platform that accumulated in slope and basinal environments (Dumoulin and Till, 1985; Ryherd and Paris, 1985, 1987; Harris and others, 1995; Dumoulin and others, 2002). It correlates, at least in part, with unit DEbm and is intercalated with, and possibly a facies equivalent of, unit DEks. DObm is lithologically similar to, and at least partly coeval with, Silurian carbonate and siliciclastic turbidites in the west-central Brooks Range (unit "Spl" of Till and others, 2008b). It also correlates in part with Middle Ordovician-lower Silurian graptolitic argillite and quartz-rich turbidites of the Iviagik Group of Martin (1970) that are exposed south of Cape Lisburne (Grantz and others, 1983; Moore and others, 1994, 2002; Harris and others, 1995). Equivalent to unit "DObm" of Till and others (1986), and partly equivalent to units "Ml?", "p€l”, and "Pzm" of Hudson (1977) and the Deceit Formation of Ryherd and Paris (1987)

\section{HIGH-GRADE METAMORPHIC AND ASSOCIATED IGNEOUS ROCKS}

PzPh High-grade metasedimentary and metaigneous rocks (Paleozoic and Proterozoic) —Brown, light-brown, reddish-brown, black, and gray-weathering schist and gneiss exposed in the Kigluaik, Bendeleben, and Darby Mountains. Highest grade metamorphic assemblages are upper amphibolite to granulite grade; assemblages in all three ranges record multiple metamorphic events. Metamorphic foliations range from gneissic to schistose; locally, foliation is lacking and crystallization of metamorphic minerals appears to be static (Till and others, 1986; Lieberman, 1988; Calvert and others, 1999). Lithologically variable on a scale of centimeters and meters, the unit includes pelitic, semi-pelitic, quartzose, calcareous, aluminous, mafic, ultramafic, and graphitic schist and gneiss. Dominant lithologies vary within each mountain range. Till and others (1986) recognized sequences of rocks lithologically similar to those mapped within the Nome Complex in western Bendeleben and northern Darby Moun- 
tains. Thurston (1985), Patrick and Lieberman (1988), Hannula and others (1995) and Calvert and others (1999) showed that the high-grade metamorphic event in the Kigluaik Mountains overprinted blueschist-facies assemblages in the Nome Complex. At least part of Pzh, perhaps a significant part, was originally blueschist-facies rocks of the Nome Complex.

Metamorphic foliations and lithologic layering in the Kigluaik Mountains define a dome, with highest-grade rocks in its core. The earliest-formed metamorphic assemblages known in the range are found at the base of the section, below Mount Osborn. There, garnets in pelitic rocks locally contain kyanite inclusions (Lieberman, 1988); garnet lherzolite occurs as large, meter-scale xenoliths in pegmatite and is present in abundance in glacial moraine (Till, 1980, 1981; Lieberman and Till, 1987). Garnet lherzolite is stable at eclogite facies (Evans, 1977; Spear, 1993). The dominant metamorphic fabric in the Kigluaiks postdates this high-pressure event and contains peak granulite-facies assemblages. Garnets in lherzolite are partially overprinted by spinel-bearing assemblages stable at granulite facies. Two-pyroxene semipelitic and mafic gneiss, diagnostic of the facies, are also found in the core of the range (Till and Dumoulin, 1994). Most of the rocks in the range crystallized at temperatures above the second sillimanite isograd (above the temperature stability of muscovite; sh. 2; Amato and Miller, 2004). Metamorphic grade decreases towards the flanks of the dome, where biotite-grade metamorphic assemblages overprint low-grade metamorphic assemblages of the Nome Complex (Thurston, 1985; Hannula and others, 1995; Amato and Miller, 2004). Metamorphic isograds along the flanks of the dome are closely spaced (Till, 1980; Patrick and Lieberman, 1988; Miller and others, 1992; Amato and Miller, 2004).

Metamorphic foliations in the Bendeleben Mountains define a dome that spans the area between the large, ovoid pluton in the eastern part of the range and the smaller, irregularly shaped pluton in the west part of the range; the dome coincides with sillimanite-bearing peak thermal assemblages (Gottlieb and Amato, 2008). West of the dome, southwest of Mount Bendeleben, kyanite-bearing assemblages predate sillimanite-bearing assemblages in pelitic rocks (sh. 2; Till and Dumoulin, 1994; Till, unpub. data). Kyanite-bearing assemblages are apparently the oldest in the range.

Metamorphic rocks in the Darby Mountains lack any domal structure; instead, mapscale folds of lithologic sequences with near-vertical axial planes are present where rocks exhibit higher-grade assemblages (Till and others, 1986). In the northern Darby Mountains, units of the low-grade Nome Complex are shallowly-dipping and partially overprinted by biotite-grade metamorphic assemblages (Till and others, 1986). Southward along the crest of the range, kyanite- and staurolite-bearing assemblages occur. Kyanite is texturally older and may be relict of an earlier metamorphic event. Farther south, the appearance of sillimanite and locally sillimanite plus K-feldspar in pelitic schists indicates an increase in metamorphic grade. Metamorphic grade culminates near Mount Arathlatuluk. There, rare two pyroxene schists are diagnostic of granulite facies, and small granitic bodies appear to be anatectic melts (sh. 2). The anatectic granites were formed around $108 \mathrm{Ma}$ (R. Friedman, written commun., 2009). A fault-bounded block of high-grade rocks on the western flank of the Darby range contains similar high-grade metamorphic assemblages (formed above the second-sillimanite isograd) (sh. 2).

In all three mountain ranges, decompression post-dated the thermal peak, and is recorded in aluminum- and iron-rich metasedimentary rocks. In these volumetrically minor but significant rocks, assemblages containing sillimanite or kyanite ( \pm hercynite spinel) and orthoamphibole were overprinted by assemblages containing cordierite and staurolite or garnet (sh. 2). Corona or symplectite textures are common in these rocks. The aluminosilicate plus orthoamphibole assemblage is stable at moderate to high pressures, above about $5 \mathrm{~kb}$, and the cordierite-bearing assemblage is stable at low pressures, below about $5 \mathrm{~kb}$ (Spear, 1993). While decompression assemblages apparently formed at about $82 \mathrm{Ma}$ in the Bendeleben range (Gottlieb and Amato, 2008), similar assemblages in the Darby range are probably older: the 100-Ma Darby pluton cross-cuts the metamorphic gradient in the Darby range; andalusite formed in its contact aureole (sh. 2). Andalusite forms at pressures lower than $4 \mathrm{~kb}$.

These high-grade metamorphic rocks are equivalent to generalized units " $\mathrm{Pz} p \mathrm{ph}$ ", "Pz€g", "Pzp€g" and units representing upgraded Nome Complex "Oimh", "Ocsh", "O€xh" and "€p€sh" of Till and others (1986)

PzEm Marble (Paleozoic to Proterozoic?) - Light-gray-weathering, coarse-grained pure and impure marble interlayered with unit Pzh. Commonly massive, though locally meter-thick layers 
are separated by thin (centimeter-scale) layers of fine-grained impurities. Thin sections show equilibrium metamorphic textures involving calcite, dolomite, phlogopite, tremolite, quartz, scapolite, diopside, and graphite. Equivalent to unit "Pzp€m" of Till and others (1986)

$\mathrm{PzEg}$ Gneiss and orthogneiss (Paleozoic? and Proterozoic?) —Light-brownish-gray, light-orange to gray biotite-plagioclase-quartz gneiss and granitic orthogneiss and minor metasedimentary rocks exposed in rubble crop north of the Oonatut Granite Complex, northwest Bendeleben quadrangle (Hudson, 1979). Fabric in the gneiss is defined by discontinuous layers and lenses of plagioclase and quartz and discontinuous concentrations of biotite. Orthogneiss is fine grained, homogeneous in texture, with foliation defined by aligned and segregated muscovite and minor biotite. Calcite marble layers, less than $10 \mathrm{~cm}$ thick, are folded in with the orthogneiss at one locality. Minor hornblende-plagioclase-titanite amphibolite and pelitic metasedimentary rocks are found in southern part of the unit, and close to the Oonatut Granite Complex the metasedimentary rocks contain porphyroblasts of andalusite (Till, unpub. data). Contacts with the Nome Complex are thought to be structural (Hudson, 1979). Equivalent to units "p€gn" and "p€gog" of Hudson (1979)

Po Orthogneiss (Proterozoic) -Pale-gray-, tan- and orangish-tan-weathering outcrops and rubble fields of foliated and unfoliated metagranitic rocks that form a large, tabular, concordant body within high-grade rocks of the Kigluaik Mountains. Called the "Thompson Creek orthogneiss" after exposures in Nome D-1 quadrangle (Till, 1980; Amato and Miller, 2004), the rock is syenogranite to monzogranite in composition (Streckeisen, 1976). Potassiumfeldspar, plagioclase, and biotite are locally aligned in foliation; quartz and biotite lenses or layers up to a centimeter thick also parallel foliation. Allanite is locally 1 to 2 percent of the rock and is zoned with brown cores and orange rims; accessory zircon is also present. Quartz amphibolite layers that are parallel to metamorphic foliation in the orthogneiss are 1-2 $\mathrm{m}$ thick. Amato and Miller (2004) show the Thompson Creek orthogneiss on both the north and south flank of the antiform in the core of the Kigluaik Mountains (their unit "pCtog"). Orthogneiss yielded U-Pb zircon ages of $555 \pm 15 \mathrm{Ma}$ (Amato and Wright, 1998) and $565 \pm 6$ Ma (Amato, 2004)

Ev Metavolcanic rocks (Proterozoic) - Foliated lens- to sill-shaped bodies in western Bendeleben Mountains exposed in outcrop and rubble fields. Unit is up to $50 \mathrm{~m}$ thick. Very fine grain size and variation in abundance and relative proportion of biotite and hornblende suggest a volcanic protolith (Amato and others, 2009). Foliation is defined by the parallel alignment of biotite and feldspar. Grain size varies from layer to layer locally. Contacts and internal foliation are conformable to the foliation of the enclosing metamorphic rocks where exposed. These are the oldest dated rocks on Seward Peninsula, having yielded a U-Pb zircon age of $870 \mathrm{Ma}$ (Gottlieb and Amato, 2007, 2008; Amato and others, 2009)

\section{KUGRUK FAULT ZONE}

TKs Carbonate-rich conglomerate and sandstone; mudstone, siltstone and coal (Tertiary and Cretaceous) - Two separate sedimentary sequences, of broadly different age: tan to lightgray siltstone, sandstone, and pebbly sandstone, and light-gray-weathering conglomerate composed mostly of marble, metalimestone, and dolostone clasts, probably of mid-Cretaceous age; and a separate sequence of gray and brown siltstone, mudstone, sandstone, coal, and minor conglomerate of Late Cretaceous and Tertiary age. Both sequences are exposed in narrow slices along the Kugruk Fault Zone. Mid-Cretaceous carbonate-rich sandstone and siltstone are found in southeastern and east-central parts of the Bendeleben quadrangle; conglomerate is found in these areas as well but also forms scattered outcrops in southeastern Solomon and southwestern Norton Bay quadrangles, where it is the dominant lithology. The younger sequence is poorly exposed in northeastern and southeastern Bendeleben quadrangle; it has been explored for coal and uranium (Retherford and others, 1986; Dickinson and others, 1987).

The older sequence, carbonate-rich sedimentary rocks, is better exposed. Carbonaterich sandstone and siltstone typically occur as rubble-covered hills but are best exposed in river-cliff outcrops in Bendeleben C-2 quadrangle. Rocks are friable to well indurated, calcite cemented, and form beds 5 to $60 \mathrm{~cm}$ thick; sedimentary structures include graded bedding, channels, small scale ripples, and crossbeds. Some fine-grained layers are rich in carbonaceous plant debris and coal seams are locally well developed. Most samples consist of poorly to moderately well sorted, angular to rounded grains. Clasts appear to 
have been derived primarily from adjacent metamorphic rocks; clast lithologies include marble, dolostone, plagioclase, monocrystalline and polycrystalline quartz, volcanic rocks (with felsitic and lathwork textures), blueschist-facies metabasite, radiolarian chert, phyllite, quartz-mica schist, and amphibolite. Carbonate clasts predominate at most localities.

Conglomerate, associated with minor sandstone and pebbly sandstone, forms rounded knobs up to $25 \mathrm{~m}$ high and more extensive areas of rubble crop. Bedding is rarely evident, but sandy interbeds and crude grading are locally present. Rocks are very poorly sorted and have a matrix of calcite cement and carbonate sand. Cobbles are sub-rounded to rounded; maximum clast diameter at outcrops studied ranges from 52 to $72 \mathrm{~cm}$. Pebble counts indicate that carbonate clast content varies from a low of 81 percent in Bendeleben $\mathrm{C}-2$ quadrangle to a high of 98 percent in Bendeleben A-1 quadrangle. Marble and metalimestone versus dolostone ratios range from 1:2 in Bendeleben A-1 quadrangle to 3:1 in Bendeleben C-2 quadrangle. Non-carbonate clasts include chert, monocrystalline and polycrystalline quartz, quartz-mica schist, chlorite schist, and various greenstone lithologies that were likely derived from the adjacent unit MzPzm.

Two small outcrops of mafic clast conglomerate underlie carbonate conglomerate in Bendeleben C-2 quadrangle. Sorting in these rocks is poor; clasts are rounded to angular and as much as $30 \mathrm{~cm}$ in diameter. Clasts are mainly metavolcanic rocks, some of which contain blue amphibole; subordinate clast lithologies include radiolarian chert, marble, quartz, and quartz-mica schist.

The calcareous sediments are locally intruded by sills (too small to show on this map) of probable Tertiary or Cretaceous age; the sediments are unmetamorphosed but deformed and vertical beds occur locally. No fossils constrain the depositional age of the conglomerates, but ages of some clasts have been determined. Carbonate clasts from six localities yielded 21 conodont collections, 19 of which have CAI values of 5-6 (table A-1). Relatively wellconstrained clast ages are mainly Silurian and Devonian; the tightest ages are Middle to Late Ordovician, early to middle Silurian, middle to late Silurian (Wenlock-Ludlow), late Early Devonian (late Emsian), and Middle Devonian. Conodont biofacies of several of the Silurian clasts indicate a high-energy, shallow-water depositional setting (Till and others, 1986). The lithofacies, thermal level, age, and biofacies of the carbonate clasts correlate well with those of units $\mathrm{Od}, \mathrm{Sd}$, and Ddm; thus, carbonate cobbles in TKs most likely were derived largely from these units. Carbonate clasts of Silurian age and shallow-water biofacies appear to be volumetrically over-represented relative to the present areal distribution of such rocks. The carbonate-rich clastic rocks of TKs may have been deposited in a series of small alluvial fans.

The mid-Cretaceous carbonate-rich sedimentary sequences exposed east of Seward Peninsula in the Yukon-Koyukuk basin (Nilsen, 1989; Patton and others, 2005) are thought to be correlative with the carbonate-rich sedimentary rocks of unit TKs.

The younger sequence in TKs is exposed in creek bottoms in Bendeleben D-1 quadrangle and in a small area south of Death Valley, in Bendeleben A-1 quadrangle. In the northern locality, lignite, up to $30 \mathrm{~m}$ thick, is interbedded with siltstone, mudstone, and sandstone along a strike length of almost three-quarters of a mile, based on drilling results; bedding is steeply dipping (Retherford and others, 1986). Pollen assemblages of Late Cretaceous and Tertiary (Eocene to early Miocene?) ages have been found in finer grained parts of the sequence (Till and others, 1986; Haga, in Retherford and others, 1986). Drilling results show that schists of the Nome Complex sit structurally above parts of the sequence (Retherford and others, 1986).

In southeastern Bendeleben quadrangle, the younger sequence is also exposed in a small area south of Death Valley. Early Eocene and younger sedimentary and basaltic rocks accumulated in a small graben and are interleaved with basaltic rocks (Dickinson and others, 1987). Sandstone, mudstone, conglomerate and coal beds up to $55 \mathrm{~m}$ thick were documented in drill core. Sandstones in the core host an epigenetic and supergene uranium deposit (Dickinson and others, 1987). A similar sequence of sedimentary and volcanic rocks probably underlies Death Valley.

Unit is equivalent to units "Kc" of Miller and others (1972), "Klcg" of Sainsbury (1974), "TKs" and "TKc" of Till and others (1986), and "Kcc" of Patton and others (2005); also partly equivalent to units "Kss", "Kls", and "TKs" of Sainsbury (1974)

Jt Spruce Creek tonalite (Jurassic) - Tan-weathering, recessive, quartz-poor, plagioclase-rich intrusive rock. Rubble along middle to upper portions of Spruce Creek, in the headwaters 
of the Kugruk River in Bendeleben B-2 and B-3 quadrangles, is 50 to 70 percent plagioclase, 5 percent hornblende, and 25 to 45 percent quartz. Alkali feldspar is absent. A more hornblende-rich ( 30 percent), quartz-free dioritic variety is locally present. Hornblende is preserved only in northernmost exposures of the stock, along west banks of the creek. Elsewhere, no primary mafic minerals are present; hornblende is altered to mixtures of chlorite, opaque minerals, and epidote. An odd textural variety of the stock was found in one locality. Approximately 70 percent of this rock consists of concentrically radiating, spherulite-like intergrowths of plagioclase and quartz, often surrounding cores or nucleus grains of quartz or plagioclase, 0.7 to $1.7 \mathrm{~mm}$ in diameter. Several small exposures of an intrusive similar to the tonalite, thought to be fault slivers, are found along an unnamed stream that flows into the Kugruk River in the northwest corner of Bendeleben $\mathrm{C}-1$ quadrangle. Tonalite yielded a U-Pb zircon age of $163 \pm 3 \mathrm{Ma}$ (J. Aleinikoff, written commun., 1987; Till and Dumoulin, 1994). Equivalent to unit "MzPt" of Till and others (1986)

$\mathrm{MzP}$ Metamorphosed mafic rocks and serpentinite (Mesozoic and Paleozoic?) - Tectonic assemblage of metagabbro, metabasalt, amphibolite, serpentinite, and minor chert, exposed in rubble fields and poor outcrops along the trend of the Kugruk Fault Zone. Mafic rocks include minor unmetamorphosed (but altered) rocks, rocks with relict igneous textures and a single metamorphic overprint, and rocks that have experienced more than one metamorphic event. Pumpellyite- and prehnite-bearing veins that cross foliation are common in many lithologies.

In outcrop, singly metamorphosed mafic rocks are light to medium green, medium and grayish green, massive to finely color laminated. The degree of deformation varies within the unit. In thin section, metamorphic minerals statically overprint igneous textures, are weakly to well-aligned in a foliation, or the rock texture is mylonitic, with undulose extinction, grain size reduction, and microboudinage. Metagabbros and metabasalts typically retain porphyroclasts of igneous clinopyroxene that have rims of actinolite or blue amphibole. Mineral assemblages reflect a variety of metamorphic facies: actinolite-epidotechlorite-plagioclase, blue amphibole-lawsonite(?)-chlorite, blue amphibole-epidote-chlorite, and blue amphibole-pumpellyite-chlorite. These greenschist-, lawsonite-blueschist-, epidote blueschist-, and transitional blueschist-pumpellyite-actinolite-facies rocks occur over the length of the fault zone and are intermixed. The presence of multiple facies may reflect compositional variation in the mafic rocks rather than significant differences in metamorphic history. The boundaries among these facies come close to intersecting at temperatures of about $275-350{ }^{\circ} \mathrm{C}$ and pressures of $6-8 \mathrm{~kb}$ and variations in bulk rock composition shift the boundaries in pressure-temperature space (Evans, 1990). These rocks may have formed at generally similar conditions.

There are two groups of multiply metamorphosed rocks. Amphibolites composed of coarse actinolite overprinted by finer grained greenschist-facies assemblages are minor but widespread. In the northern part of the fault zone (Bendeleben D-1 and Kotzebue A-1 quadrangles) mafic rocks display evidence of an albite-epidote amphibolite facies event overprinted by a lower grade event. Blue-green amphibole, epidote, and albite, with and without garnet, occur in equilibrium metamorphic textures. These albite-epidote-amphibolite-facies assemblages are slightly to significantly overprinted by epidote-blueschist or greenschist assemblages, largely on mineral rims or cracks. The later metamorphic event is likely the same event that affected mafic rocks in the unit farther south.

Rubble crop of light-green-weathering, dark-greenish-black serpentinite is found in two large lenses in eastern Solomon quadrangle and in smaller bodies, up to $30 \mathrm{~m}$ across, in beach cliffs on Kotzebue Sound. The southern lens is the largest and is closely associated with outcrops of mylonitic metabasite.

Rare subcrop of dark rusty-brown-weathering volcaniclastic rocks occurs in Bendeleben B-2 quadrangle; rocks are fine- to medium-grained and composed of unsorted subrounded to angular clasts of aphanitic to porphyritic basalt. Basalt textures are variable; grain size, mineralogy, and vesicularity vary from clast to clast. Associated with these rocks are lesser light-gray- to orange-weathering, very fine grained porphyritic felsic rocks. Quartz and plagioclase phenocrysts sit in a slightly recrystallized, fine-grained matrix; disseminated iron oxides impart the orange color.

Unit MzPzm is equivalent of unit "Pmv" of Miller and others (1972), unit "Jv" of Sainsbury (1974), and combined units "MzPzm", "MzPzb", and "MzPzs" of Till and others (1986) 


\section{References Cited}

Aleinikoff, J.N., Moore, T.E., Walter, M., and Nokleberg, W.J., 1993, U-Pb ages of zircon, monazite, and sphene from Devonian metagranites and metafelsites, central Brooks Range, Alaska, in Dusel-Bacon, C., and Till, A.B., eds., Geologic studies in Alaska by the U.S. Geological Survey in 1992: U.S. Geological Survey Bulletin 2068, p. 59-70.

Amato, J.M., 2004, Crystalline basement ages, detrital zircon ages, and metamorphic ages from Seward Peninsula: Implications for Proterozoic and Cambrian-Ordovician paleogeographic reconstructions of the Arctic-Alaska terrane [abs.]: Geological Society of America Abstracts with Programs, 2004 Denver, Colo. Annual meeting, November 7-10, 2004, v. 36, no. 5, p. 22.

Amato, J.M., and Miller, E.L., 2004, Geologic map and summary of the evolution of the Kigluaik Mountains gneiss dome, Seward Peninsula, Alaska, in Whitney, D.L., Teyssier, C., and Siddoway, C.S., eds., Gneiss domes in orogeny: Geological Society of America Special Paper 380, p. 295-306, 1 sheet, scale 1:63,360.

Amato, J.M., Miller, E.L., Calvert, A.T., Toro, J., and Wright, J.E., 2003b, Potassic magmatism on St. Lawrence Island, Alaska, and Cape Dezhnev, northeast Russia: evidence for Early Cretaceous subduction in the Bering Strait region, in Clautice, K.H., and Davis, P.K., eds., Short notes on Alaska geology 2003: Alaska Division of Geological and Geophysical Surveys Professional Report 120A, p. 1-20.

Amato, J.M., Miller, E.L., and Gehrels, George, 2003a, Lower Paleozoic through Archean detrital zircon ages from metasedimentary rocks of the Nome Group, Seward Peninsula, Alaska [abs.]: EOS Transactions of the American Geophysical Union, v. 84, no. 46, abstract T31F-0891.

Amato, J.M., Miller, E.L., and Hannula, K.A., 2002, Orthogonal flow directions in extending continental crust: an example from the Kigluaik gneiss dome, Seward Peninsula, Alaska, in Miller, E.L., Grantz, A., and Klemperer, S., eds., Tectonic evolution of the Bering Shelf-Chukchi Sea-Arctic margin and adjacent landmasses: Geological Society of America Special Paper 360, p. 133-146.

Amato, J.M., Miller, E.L., Wright, J.E., and McIntosh, W.C., 2003c, Dike swarms on Seward Peninsula, Alaska, and their implications for the kinematics of Cretaceous extension in the Bering Strait region: Canadian Journal of Earth Sciences, v. 40, no. 6, p. 865-886.

Amato, J.M., Toro, J., Miller, E.L., and Gehrels, G.E., 2006, Late Proterozoic magmatism in Alaska and its implications for paleogeographic reconstructions of the Arctic AlaskaChukotka Plate [abs.]: Geological Society of America Abstracts with Programs, 2006 Cordilleran Section, May 8-10, 2006, v. 38, no. 5, p. 13.

Amato, J.M., Toro, J., Miller, E.L., Gehrels, G.E., Farmer, G.L., Gottlieb, E.S., and Till, A.B., 2009, Late ProterozoicPaleozoic evolution of the Arctic Alaska Chukotka terrane based on U-Pb igneous and detrital zircon ages-Implications for Neoproterozoic paleogeographic reconstructions:
Geological Society of America Bulletin, v. 121, no. 9/10, p. 1219-1235.

Amato, J.M., and Wright, J.E., 1997, Potassic mafic magmatism in the Kigluaik gneiss dome, northern Alaska-a geochemical study of arc magmatism in an extensional tectonic setting: Journal of Geophysical Research, v. 102, no. B4, p. 8065-8084.

Amato, J.M., and Wright, J.E., 1998, Geochronologic investigations of magmatism and metamorphism within the Kigluaik Mountains gneiss dome, Seward Peninsula, Alaska, in Clough, J.G., and Larson, F., eds., Short notes on Alaskan geology, 1997: Alaska Division of Geological and Geophysical Surveys Professional Report 118, p. 1-21.

Amato, J.M., Wright, J.E., Gans, P.B., and Miller, E.L., 1994, Magmatically induced metamorphism and deformation in the Kigluaik gneiss dome, Seward Peninsula, Alaska: Tectonics, v. 13 , no. 3, p. 515-527.

Armstrong, R.L., Harakal, J.E., Forbes, R.B., Evans, B.W., and Thurston, S.P., 1986, Rb-Sr and K-Ar study of metamorphic rocks of the Seward Peninsula and southern Brooks Range, Alaska, in Evans, B.W., and Brown, E.H., eds., Blueschists and eclogites: Geological Society of America Memoir 164, p. 184-203.

Arth, J.G., Criss, R.E., Zmuda, C.C., Foley, N.K., Patton, W.W., Jr., and Miller, T.P., 1989, Remarkable isotopic and trace element trends in potassic through sodic Cretaceous plutons of the Yukon-Koyukuk basin, Alaska, and the nature of the lithosphere beneath the Koyukuk terrane: Journal of Geophysical Research, v. 94, no. B11, p. 15,957-15,968.

Ayuso, R.A., and Till, Alison B., 2007, Geochemical and Nd-Pb isotopic evolution of metabasites from attenuated continental lithosphere, Nome Group, Seward Peninsula, Alaska [abs.]: Geological Society of America Abstracts with Programs, v. 39, no. 6, p. 489.

Barnes, D.F., and Hudson, T., 1977 [1978], Bouguer gravity map of Seward Peninsula, Alaska: U.S. Geological Survey Open-File Report 77-796-C, 1 sheet.

Barnes, D.F., and Morin R.L., 1988, Results of a gravity survey of McCarthy's Marsh, Seward Peninsula, Alaska: U.S. Geological Survey Open-File Report 88-0546, 12 p., 2 sheets, scale 1:63,360.

Begét, J.E., Hopkins, D.M., and Charron, S.D., 1996, The largest known Maars on Earth, Seward Peninsula, Northwest Alaska: Arctic, v. 49, no. 1, p. 62-69.

Berry, A.L., Dalrymple, G.B., Lanphere, M.A., and Von Essen J.C., 1976, Summary of miscellaneous potassium-argon age measurements, U.S. Geological Survey, Menlo Park, California, for the Years 1972-74: U.S. Geological Survey Circular 727, p. 1-13.

Bird, K.J., Burruss, R.C., and Pawlewicz, M.J., 1999, Thermal maturity, in ANWR [Arctic National Wildlife Refuge] Assessment Team, [U.S. Geological Survey], eds., The oil and gas resource potential of the 1002 Area, Arctic National Wildlife Refuge, Alaska: U.S. Geological Survey Open-File Report 98-34, p. V1-V64.

Blodgett, R.B., Rohr, D.M., and Boucot, A.J., 2002, Paleozoic linkages between some Alaskan accreted terranes and Siberia based on megafossils, in Miller, E.L., Grantz, A., 
and Klemperer, S.L., eds., Tectonic evolution of the Bering Shelf-Chukchi Sea-Arctic margin and adjacent landmasses: Boulder, Colo., Geological Society of America Special Paper 360, p. 273-290.

Bowsher, A.L., and Dutro, J.T., Jr., 1957, The Paleozoic section in the Shainin Lake area, central Brooks Range, Alaska: U.S. Geological Survey Professional Paper 303-A, 39 p.

Box, S.E., and Patton, W.W., Jr., 1989, Igneous history of the Koyukuk terrane, western Alaska - constraints on the origin, evolution, and ultimate collision of an accreted island arc terrane: Journal of Geophysical Research, v. 94, no. B11, p. 15,843-15,867.

Bradley, D.C., McClelland, W.S., Wooden, J.L., Till, A.B., Roeske, S.M., Miller, M.L., Karl, S.M., Abbott, J.G., 2007, Detrital zircon geochronology of some Neoproterozoic to Triassic rocks in interior Alaska, in Ridgway, K.D., Trop, J.M., Glen, J.M.G., and O'Neill, J.M., eds., Growth of a collisional continental margin - Crustal evolution of southcentral Alaska: Geological Society of America Special Paper, v. 431, p. 155-189.

Brooks, A.H., Richardson, G.B., Collier, A.J., and Mendenhall, W.C., 1901, Reconnaissances in the Cape Nome and Norton Bay regions, Alaska, in 1900 [Cape Nome and Norton Bay, Alaska: A reconnaissance of the Cape Nome and adjacent gold fields of Seward Peninsula Alaska, in 1900]: Washington, [D.C.], [U.S.] Government Printing Office, U.S. Geological Survey [Other Special Book], 222 p., 17 pls.

Bundtzen, T.K., Reger, R.D., Laird, G.M., Pinney, D.S., Clautice, K.H., Liss, S.A., and Cruse, G.R., 1994, Progress report on the geology and mineral resources of the Nome mining district: Alaska Division of Geological and Geophysical Surveys Public-Data File 94-39, 21 p., 2 sheets, scale 1:63,360.

Burns, L.E., Fugro Airborne Surveys Corp., and Stevens Exploration Management Corp., 2005a, Total magnetic field of the Nome mining district, Seward Peninsula, Alaska: Alaska Division of Geological and Geophysical Surveys Geophysical Report 2004-6-1A, 1 sheet, 1:63,360.

Burns, L.E., Fugro Airborne Surveys Corp., and Stevens Exploration Management Corp., 2005b, 7200 Hz coplanar apparent resistivity of the Nome mining district, Seward Peninsula, Alaska: Alaska Division of Geological and Geophysical Surveys Geophysical Report 2004-6-2A, 1 sheet, scale 1:63,360.

Calvert, A.T., Gans, P.B., and Amato, J.M., 1999, Diapiric ascent and cooling of a sillimanite gneiss dome revealed by ${ }^{40} \mathrm{Ar} /{ }^{39} \mathrm{Ar}$ thermochronology - the Kigluaik Mountains, Seward Peninsula, Alaska, in Ring, U., Brandon, M.T., Lister, G.S., and Willett, S.D., eds., Exhumation processes - normal faulting, ductile flow and erosion: London, Geological Society, Special Publications, v. 154, p. 205-232.

Christiansen, P.P., and Snee, L.W., 1994, Structure, metamorphism, and geochronology of the Cosmos Hills and Ruby ridge, Brooks Range schist belt, Alaska: Tectonics, v. 13, p. $191-213$

Collier, A.J., Hess, F.L., Smith, P.S., and Brooks, A.H., 1908,
The gold placers of parts of Seward Peninsula including the Nome, Council, Kougarok, Port Clarence, and Goodhope Precincts: U.S. Geological Survey Bulletin 328, 343 p., 1 sheet, scale 1:250,000.

Dalrymple, G.B., 1979, Critical tables for conversion of K-Ar ages from old to new constants: Geology, v. 7, p. 558-560.

Dickinson, K.A., Cunningham, K.D., and Ager, T.A., 1987, Geology and origin of the Death Valley uranium deposit, Seward Peninsula, Alaska: Economic Geology, v. 82, p. 1558-1574.

Dumitru, T.A., Miller, E.L., O’Sullivan, P.B., Amato, J.M., Hannula, K.A., Calvert, A.T., Gans, P.B., 1995, Cretaceous to recent extension in the Bering Strait region, Alaska: Tectonics, v. 14, no. 3, p. 549-563.

Dumoulin, J.A., 2001, Lithologies of the basement complex (Devonian and older) in the National Petroleum Reserve-Alaska, in Houseknecht, D.W., ed., NPRA Core Workshop; Petroleum Plays and Systems in the National Petroleum Reserve-Alaska: Society of Economic Paleontologists and Mineralogists, SEPM Core Workshop, v. 21, p. 201-214.

Dumoulin, J.A., and Harris, A.G., 1994, Depositional framework and regional correlation of pre-Carboniferous metacarbonate rocks of the Snowden Mountain area, central Brooks Range, northern Alaska: U.S. Geological Survey Professional Paper 1545, $74 \mathrm{p}$.

Dumoulin, J.A., Harris, A.G., Gagiev, M., Bradley, D.C., and Repetski, J.E., 2002, Lithostratigraphic, conodont, and other faunal links between lower Paleozoic strata in northern and central Alaska and northeastern Russia, in Miller, E.L., Grantz, A., and Klemperer, S.L., eds., Tectonic evolution of the Bering Shelf-Chukchi Sea-Arctic margin and adjacent landmasses: Boulder, Colo., Geological Society of America Special Paper 360, p. 291-312.

Dumoulin, J.A., and Till, A.B., 1985, Seacliff exposures of metamorphosed carbonate and schist, northern Seward Peninsula, in Bartsch-Winkler, S., and Reed, K.M., eds., The United States Geological Survey in Alaska; accomplishments during 1983: U.S. Geological Survey Circular 945 , p. 18-22.

Dusel-Bacon, C., Brosgé, W.P., Till, A.B., Doyle, E.O., Mayfield, C.F., Reiser, H.N., and Miller, T.P., 1989, Distribution, facies, ages, and proposed tectonic associations of regionally metamorphosed rocks in northern Alaska: U.S. Geological Survey Professional Paper 1497-A, p. A1-A44, 2 sheets, scale 1:1,000,000.

Dutro, J.T., Jr., Brosgé, W.P., Reiser, H.N., and Detterman, R.L., 1979, Beaucoup Formation, a new Upper Devonian stratigraphic unit in the central Brooks Range, Alaska, in Sohl, N.F., and Wright, W.B., Changes in stratigraphic nomenclature by the U.S. Geological Survey, 1978: U.S. Geological Survey Bulletin 1482-A, p. A62-A69.

Epstein, A.G., Epstein, J.B., and Harris, L.D., 1977, Conodont color alteration-an index to organic metamorphism: U.S. Geological Survey Professional Paper 995, 27 p.

Evans, B.W., 1977, Metamorphism of alpine peridotite and serpentinite: Annual Review Earth Planetary Science, v. 5, p. $397-447$. 
Evans, B.W., 1990, Phase relations of epidote-blueschists: Lithos, v. 25, p. 3-23.

Evans, B.W., and Patrick, B.E., 1987, Phengite 3-T in high pressure orthogneisses, Seward Peninsula, Alaska: Canadian Mineralogist, v. 25, p. 141-158.

Flower, R.H., 1968, Endoceroids from the Canadian of Alaska and A Chazyan cephalopod fauna from Alaska: New Mexico Institute of Mining and Technology Memoir 21, pts. III and IV, p. 13-35.

Forbes, R.B., Evans, B.W., and Thurston, S.P., 1984, Regional progressive high-pressure metamorphism, Seward Peninsula, Alaska: Journal of Metamorphic Geology, v. 2, p. 43-54.

Ford, R.C., and Snee, L.W., 1996, ${ }^{40} \mathrm{Ar} /{ }^{39} \mathrm{Ar}$ thermochronology of white mica from the Nome district, Alaska - the first ages of lode sources to placer gold deposits in the Seward Peninsula: Economic Geology, v. 91, no. 1, p. 213-220.

Gottlieb, E.S., and Amato, J.M., 2007, Geologic mapping, structural analysis, and geochronology of the Bendeleben Mountains metamorphic complex, Seward Peninsula, Alaska [abs.]: Geological Society of America Abstracts with Programs, 2006 Cordilleran Section, May 4-6, 2007, v. 39 , no. 4, p. 5 .

Gottlieb, E.S., and Amato, J.M., 2008, Structural evolution, transition from anatectic to mantle-derived magmatism, and timing of exhumation-Bendeleben metamorphic complex, Seward Peninsula, Alaska [abs.]: Geological Society of America Abstracts with Programs, Cordilleran Section and Rocky Mountain Section Joint Meeting, March 19-21, 2008, v. 40, no. 1, p. 97.

Gottschalk, R.R., 1998, Petrology of eclogite and associated high-pressure metamorphic rocks, south-central Brooks Range, Alaska, in Oldow, J.S., and Avé Lallemant, H.G., eds., Architecture of the central Brooks Range fold and thrust belt, Arctic Alaska: Boulder, Colorado, Geological Society of America Special Paper 324, p. 141-162.

Gottschalk, R.R., and Snee, L.W., 1998, Tectonothermal evolution of metamorphic rocks in the south-central Brooks Range, Alaska; constraints from ${ }^{40} \mathrm{Ar} /{ }^{39} \mathrm{Ar}$ geochronology, in Oldow, J.S., and Avé Lallemant, H.G., eds., Architecture of the central Brooks Range fold and thrust belt, Arctic Alaska: Boulder, Colo., Geological Society of America Special Paper 324, p. 225-251.

Gradstein, F.M., and Ogg, J.G., 2005, Time scale, in Selley, R.C., Cocks, L.R.P., and Plimer, I.R., eds., Encyclopedia of geology: London, Imperial College, Elsevier Academic Press, v. 5.

Grantz, A., Moore, T.E., and Roeske, S.M., 1991, Continentocean transect A-3 - Gulf of Alaska to Arctic Ocean: Geological Society of America, Centennial Continent-Ocean transect 15, scale 1:500,000, 3 sheets, 72 p.

Grantz, A., Tailleur, I.L., and Carter, C., 1983, Tectonic significance of Silurian and Ordovician graptolites, Lisburne Hills, northwest Alaska [abs.]: Geological Society of America Abstracts with Programs, v. 15, p. 274.

Hannula, K.A., 1993, Relations between deformation, metamorphism, and exhumation in the Nome Group blueschistgreenschist terrane, Seward Peninsula, Alaska: Stanford
University Ph.D. dissertation, 171 p., 5 pls.

Hannula, K.A., and McWilliams, M.O., 1995, Reconsideration of the age of blueschist facies metamorphism on the Seward Peninsula, Alaska, based on phengite ${ }^{40} \mathrm{Ar} /{ }^{39} \mathrm{Ar}$ results: Journal of Metamorphic Geology, v. 13, p. 125-139.

Hannula, K.A., Miller, E.L., Dumitru, T.A., and Lee, J., 1995, Structural and metamorphic relations in the southwest Seward Peninsula, Alaska-Crustal extension and the unroofing of blueschists: Geological Society of America Bulletin, v. 107, no. 5, p. 536-553.

Harris, A.G., Dumoulin, J.A. , Repetski, J.E., and Carter, C., 1995, Correlation of Ordovician rocks of northern Alaska, in Cooper, J.D., Droser, M.L., and Finney, S.C., eds., Ordovician odyssey: Short papers for the 7th International Symposium on the Ordovician system: Fullerton, Calif., Pacific Section for Sedimentary Geology (SEPM), Book 77 , p. $21-26$.

Harris, A.G., Harris, L.D., and Epstein, J.B., 1978, CAI and gas data from Paleozoic rocks in the Appalachian basin-Maps for assessing hydrocarbon potential and thermal maturity (conodont color alteration isograds and overburden isopachs): U.S. Geological Survey Miscellaneous Investigations Series Map I-917-B, 4 sheets, scale 1:2,500,000.

Harris, A.G., Lane, H.R., Tailleur, I.L., and Ellersieck, I., 1987, Conodont thermal maturation patterns in Paleozoic and Triassic rocks, northern Alaska-Geologic and exploration implications: Society of Economic Paleontologists and Mineralogists Pacific Section and Alaska Geological Society, Book 50, p. 181-194.

Hopkins, D.M., 1963, Geology of the Imuruk Lake area, Seward Peninsula, Alaska: U.S. Geological Survey Bulletin 1141-C, 101 p., 4 pls., scale 1:125,000.

Hopkins, D.M., 1988, The Espenberg Maars: a record of explosive volcanic activity in the Devil Mountain-Cape Espenberg area, Seward Peninsula, Alaska, in Schaaf, J., ed., The Bering Land Bridge-An archeological survey, Nome, Alaska: U.S. National Park Service, p. 188-247.

Hopkins, D.M., Matthews, J.V., Wolfe, J.A., and Silberman, M.L., 1971, A Pliocene flora and insect fauna from the Bering Strait region: Palaeogeography, Palaeoclimatology, Palaeoecology, v. 9, p. 211-231.

Hopkins, D.M., Rowland, R.W., Echols, R.E., and Valentine, P.C., 1974, An Anvilian (early Pleistocene) marine fauna from western Seward Peninsula Alaska: Quaternary Research, v. 4, p. 441-470.

Hudson, T., 1977, Geologic map of the Seward Peninsula, Alaska: U.S. Geological Survey Open-File Report 77-796A, 1 sheet, scale 1:1,000,000.

Hudson, T., 1979, Igneous and metamorphic rocks of the Serpentine Hot Springs area, Seward Peninsula, Alaska: U.S. Geological Survey Professional Paper 1079, 27 p., 1 sheet, scale 1:48,000.

Hudson, T., and Arth, J.G., 1983, Tin granites of Seward Peninsula, Alaska: Geological Society of America Bulletin, v. 94, p. 768-790.

Kaufman, D.S., 1985, Windy Creek and Crater Creek faults, Seward Peninsula, in Bartsch-Winkler, S., and Reed, K.M., 
eds., The United States Geological Survey in Alaska; accomplishments during 1983: U.S. Geological Survey Circular 945, p. 18-22.

Kaufman, D.S., and Hopkins, D.M., 1985, Late Cenozoic radiometric dates, Seward and Baldwin Peninsulas, and adjacent continental shelf, Alaska: U.S. Geological Survey OpenFile Report 85-374, 27 p.

Kaufman, D.S., Walter, R.C., Brigham-Grette, J., and Hopkins, D.M., 1991, Middle Pleistocene age of the Nome River glaciations, northwestern Alaska: Quaternary Research, v. 36, p. 277-293.

Layer, P.W., and Newberry, R.J., 2004, A long-term effort to determine ${ }^{40} \mathrm{Ar} /{ }^{39} \mathrm{Ar}$ ages of Alaskan mineral deposits: Unpublished final report for USGS MRERP grant 04HQGR0163; accessed September 20, 2009, at http://minerals.usgs.gov/mrerp/reports/Layer_Report04HQGR0163.pdf.

Lieberman, J.E., 1988, Metamorphic and structural studies of the Kigluaik Mountains western Alaska: Seattle, Wash., University of Washington, Ph.D. dissertation, 192 p., 53 figs.

Lieberman, J.E., and Till, A.B., 1987, Possible crustal origin of garnet lherzolite - evidence from the Kigluaik Mountains, Alaska [abs.]: Geological Society of America Abstracts with Programs, v. 19, p. 746.

Martin, A.J., 1970, Structure and tectonic history of the western Brooks Range, De Long Mountains and Lisburne Hills, Northern Alaska: Geological Society of America Bulletin, v. 81, p. $3605-3622$.

Miller, E.L., Calvert, A.T., and Little, T.A., 1992, Strain-collapsed metamorphic isograds in a sillimanite gneiss dome, Seward Peninsula, Alaska: Geology, v. 20, p. 487-490.

Miller, E.L., Gelman, M., Parfenov, L., and Hourigan, J., 2002, Tectonic setting of Mesozoic magmatism-A comparison between northeastern Russia and the North American Cordillera, in Miller, E.L., Grantz, A., and Klemperer, S.L., eds., Tectonic evolution of the Bering Shelf-Chukchi SeaArctic margin and adjacent landmasses: Geological Society of America Special Paper 360, p. 313-332.

Miller, E.L., and Hudson, T.L., 1991, Mid-Cretaceous extensional fragmentation of a Jurassic-Early Cretaceous compressional orogen, Alaska: Tectonics, v. 10, p. 781-796.

Miller, E.L., Ireland, T.R., Klemperer, S.L., Wirth, K.R., Akinin, V.V., and Brocher, T.M., 2002, Constraints on the age of formation of seismically reflective middle and lower crust beneath the Bering Shelf-SHRIMP zircon dating of xenoliths from Saint Lawrence Island, in Miller, E.L., Grantz, A., and Klemperer, S.L., eds., Tectonic evolution of the Bering Shelf-Chukchi Sea-Arctic margin and adjacent landmasses: Geological Society of America Special Paper 360, p. 195-208.

Miller, T.P., 1972, Potassium-rich alkaline intrusive rocks of western Alaska: Geological Society of America Bulletin, v. 83 , no. 7 , p. 2111-2128.

Miller, T.P., 1989, Contrasting plutonic rock suites of the Yukon-Koyukuk basin and the Ruby Geanticline, Alaska: Journal of Geophysical Research, v. 94, no. B11, p. 15,969-15,987.
Miller, T.P., and Bunker, C.M., 1976, A reconnaissance study of the uranium and thorium contents of plutonic rocks of the southeastern Seward Peninsula, Alaska: U.S. Geological Survey Journal of Research, v. 4, no. 3, p. 367-377.

Miller, T.P., Grybeck, D.G., Elliott, R.L., and Hudson, T., 1972, Preliminary geologic map of the eastern Solomon and southeastern Bendeleben quadrangles, eastern Seward Peninsula, Alaska: U.S. Geological Survey Open-File Report no. 1767,11 p., 2 sheets, scale 1:250,000.

Moll-Stalcup, E.J., 1994, Latest Cretaceous and Cenozoic magmatism in mainland Alaska, in Plafker, G., and Berg, H.C., eds., Geology of Alaska, Geology of North America (GNA-G1), v. G-1, p. 589-619.

Moore, T.E., Dumitru, T.A., Adams, K.E., Witebsky, S.N., Harris, A.G., 2002, Origin of the Lisburne Hills-Herald Arch structural belt-Stratigraphic, structural, and fissiontrack evidence from the Cape Lisburne area, northwestern Alaska, in Miller, E.L., Grantz, A., and Klemperer, S.L., eds., Tectonic evolution of the Bering Shelf-Chukchi SeaArctic margin and adjacent landmasses: Geological Society of America Special Paper 360, p. 77-109.

Moore, T.E., Wallace, W.K., Bird, K.J., Karl, S.M., Mull, C.G., and Dillon, J.T., 1994, The geology of Northern Alaska, in Plafker, G., and Berg, H.C., eds., The Geology of Alaska: Boulder, Colo., Geological Society of America, The Geology of North America, v. G-1, p. 49-140.

Moore, T.E., Wallace, W.K., Mull, C.G., Adams, K.E., Plafker, G., and Nokleberg, W.J., 1997, Crustal implications of bedrock geology along the Trans-Alaska Crustal Transect (TACT) in the Brooks Range, northern Alaska: Journal of Geophysical Research, v. 102, p. 20,645-20,684.

Newberry, R.J., Werdon, M.B., Stevens, D.S.P., Athey, J.E., and Szumigala, D.J., 2005, Geologic map of the Council area, Solomon D-4 and Bendeleben A-4 quadrangles, Seward Peninsula, Alaska: Alaska Division of Geological and Geophysical Surveys Report of Investigation 2005-1D, 1 sheet, scale 1:50,000.

Nilsen, T.H., 1989, Stratigraphy and sedimentology of the midCretaceous deposits of the Yukon-Koyukuk Basin, west central Alaska: Journal of Geophysical Research, v. 94, no. B11, p. 15,925-15,940.

North American Commission of Stratigraphic Nomenclature (NACSN), 2005, North American Stratigraphic Code: American Association of Petroleum Geologists (AAPG) Bulletin, v. 89, no. 11, p. 1547-1591, (http://ngmdb.usgs. gov/Info/NACSN/Code2/code2.html).

Oliver, W.A., Jr., Merriam, C.W., and Churkin, M., Jr., 1975, Ordovician, Silurian, and Devonian corals of Alaska: U.S. Geological Survey Professional Paper 823-B, p. 13-44.

Ormiston, A.R., 1978, Monorakos (Trilobita) from the Ordovician of the Seward Peninsula, Alaska: Journal of Paleontology, v. 52, p. 345-352.

Ormiston, A.R., and Ross, R.J., Jr., 1979, Monorakos in the Ordovician of Alaska and its zoogeographic significance, in Gray, J., and Boucot, A.J., eds., Historical biogeography, plate tectonics, and the changing environment: Corvallis, Oregon State University Press, p. 53-59.

Pallister, J.S., Budahn, J.R., and Murchey, B.L., 1989, Pillow 
basalts of the Angayucham Terrane-Oceanic plateau and island crust accreted to the Brooks Range: Journal of Geophysical Research, v. 94, p. 15,901-15,923.

Patrick, B.E., 1988, Synmetamorphic structural evolution of the Seward Peninsula blueschist terrane, Alaska: Journal of Structural Geology, v. 10, p. 555-565.

Patrick, B.E., and Evans, B.W., 1989, Metamorphic evolution of the Seward Peninsula blueschist terrane, Alaska: Journal of Petrology, v. 30, p. 531-556.

Patrick, B.E., Evans, B.W., Dumoulin, J.A., and Harris, A.G., 1985, A comparison of carbonate mineral and conodont color alteration index thermometry, Seward Peninsula, Alaska [abs.]: Geological Society of America Abstracts with Program, v. 17, no. 6, p. 399.

Patrick, B.E., and Lieberman, J.E., 1988, Thermal overprint of blueschists of the Seward Peninsula: The Lepontine [Alps] in Alaska: Geology, v. 16, p. 1,100-1,103.

Patrick, B.E., and McClelland, W.C., 1995, Late Proterozoic granitic magmatism on Seward Peninsula and a Barentian origin for Arctic Alaska-Chukotka: Geology, v. 23, no. 1, p. 81-84.

Patton, W.W., Jr., 1967, Regional geologic map of the Candle Quadrangle, Alaska: U.S. Geological Survey Miscellaneous Investigation 492, 1 sheet, scale 1:250,000.

Patton, W.W., Jr., and Box S.E., 1989, Tectonic setting of the Yukon-Koyukuk basin and its borderlands, Western Alaska: Journal of Geophysical Research, v. 94, no. B11, p. $15,807-15,820$.

Patton, W.W., Jr., and Csejtey, B., Jr., 1980, Geologic map of St. Lawrence Island, Alaska: U.S. Geological Survey Miscellaneous Investigations Series Map I-1203, 1 sheet, scale $1: 250,000$.

Patton, W.W., Jr., Stern, T.W., Arth, J.G., and Carlson, C., 1987, $\mathrm{New} \mathrm{U} / \mathrm{Pb}$ ages from granite and granite gneiss in the Ruby Geanticline and southern Brooks Range, Alaska: Journal of Geology, v. 95, no. 1, p. 118-126.

Patton, W.W., Jr., and Tailleur, I.L., 1977, Evidence in the Bering Strait region for differential movement between North America and Eurasia: Geological Society of America Bulletin, v. 88, p. 1298-1304.

Patton, W.W., Jr., Wilson, F.H., Labay, K.A., and Shew, N., 2005, Digital data for the reconnaissance geologic map of the Yukon-Koyukuk Basin, Alaska: U.S. Geological Survey Open-File Report 2005-1341, 2 sheets, scale 1:500,000.

Plafker, G., Gilpin, L.M., and Lahr, J.C., 1994, Neotectonic map of Alaska, in Plafker, G., and Berg, H.C., eds., Geology of Alaska: Boulder, Colo., Geological Society of America, Geology of North America (GNA-G1), v. G-1, plate 12, scale 1:2,500,000.

Pollock, S.M., 1982, Structure, petrology and metamorphic history of the Nome Group blueschist terrane, Salmon Lake area, Seward Peninsula, Alaska: Seattle, University of Washington, Masters thesis, 221 p., 2 sheets, scale 36,680.

Potter, A.W., 1984, Paleobiogeographical relations of Late Ordovician brachiopods from the York and Nixon Fork terranes, Alaska [abs.]: Geological Society of America Abstracts with Programs, v. 16, no. 6, p. 626.
Reed, B.L., Menzie, W.D., McDermott, W.D., Root, D.H., Scott, W., and Drew L.J., 1989, Undiscovered lode tin resources of the Seward Peninsula, Alaska: Economic Geology, v. 84, p. 1936-1947.

Rejebian, V.A., Harris, A.G., and Huebner, J.S., 1987, Conodont color and textural alteration-An index to regional metamorphism, contact metamorphism, and hydrothermal alteration: Geological Society of America Bulletin, v. 99, p. 471-479.

Retherford, R.M., Hinderman, T.K., and Hawley, C.C., eds., 1986, Preliminary feasibility study of a coal mine at Chicago Creek: Alaska Division of Geological and Geophysical Surveys, Public-data File 86-25, 172 p., 2 sheets, scale $1: 2,400$.

Roeske, S.M., Dusel-Bacon, C., Aleinikoff, J.N., Snee, L.W., and Lanphere, M.A., 1995, Metamorphic and structural history of continental crust at a Mesozoic collisional margin, the Ruby Terrane, central Alaska: Journal of Metamorphic Geology, v. 113, no. 1, p. 25-40.

Roeske, S.M., and McClelland, W.C., 1997, Preservation of the subduction zone boundary between the Ruby Terrane and Tozitna Terrane, West-Central Alaska [abs.]: Geological Society of America Abstracts with Programs, v. 29, no. 5, p. 60.

Rohr, D.M., 1979, Geographic distribution of the Ordovician gastropod Maclurites, in Gray, J., and Boucot, A.J., eds., Historical biogeography, plate tectonics, and the changing environment: Corvallis, Oregon State University Press, p. $45-52$.

Rohr, D.M., 1988, Upper Ordovician gastropods from the Seward Peninsula, Alaska: Journal of Paleontology, v. 62, p. 551-565.

Rohr, D.M., Fryda, J., and Blodgett, R.B., 2003, Alaskadiscus, a new bellerophontoidean gastropod from the Upper Ordovician of the York and Farewell terranes of Alaska, in Clautice, K.H., and Davis, P.K., eds., Short notes on Alaska geology 2003: Alaska Division of Geological and Geophysical Surveys Professional Report 120, p. 95-99.

Rohr, D.M., and Potter, A.W., 1987, Rousseauspira-A new gastropod operculum from the Ordovician of Alaska and California: Journal of Paleontology, v. 61, no. 2, p. 284-289.

Ross, R.J., Jr., 1965, Early Ordovician trilobites from the Seward Peninsula, Alaska: Journal of Paleontology, v. 39, no. 1, p. 17-20.

Ross, R.J., Jr., 1967, Anomalograptus from the Seward Peninsula, Alaska: Journal of Paleontology, v. 41, p. 1276-1278.

Ross, R.J., Jr., Adler, F.J., Amsden, T.W., Bergstrom, D., Bergstrom, S.M., Carter, Claire, Churkin, Michael, Cressman, E.A., Derby, J.R., Dutro, J.T., Jr., Ethington, R.L., Finney, S.C., Fisher, D.W., Fisher, J.H., Harris, A.G., Hintze, L.F., Ketner, K.B., Kolota, D.L., Landing, Ed, Newman, R.B., Sweet, W.C., Pojeta, John, Jr., Potter, A.W., Rader, E.K., Repetski, J.E., Shaver, R.H., Thompson, T.L., and Webers, G.F., 1982, The Ordovician System in the United States; Correlation chart and explanatory notes: International Union of Geological Sciences Publication 12, 73 p., 3 sheets. 
Ryherd, T.J., Carter, C., and Churkin, M., Jr., 1995, Middle through Upper Ordovician graptolite biostratigraphy of the Deceit Formation, northern Seward Peninsula, Alaska [abs.]: Geological Society of America Abstracts with Programs, v. 27, no. 5, p. 75 .

Ryherd, T.J., and Paris, C.E., 1985, Lower Paleozoic carbonate slope sequence, northern Seward Peninsula, Alaska [abs.]: American Association of Petroleum Geologists Bulletin, v. 69, no. 4, p. 667.

Ryherd, T.J., and Paris, C.E., 1987, Ordovician through Silurian carbonate base-of-slope apron sequence, northern Seward Peninsula, Alaska [abs.], in Tailleur, I.L., and Weimer, Paul, eds., Alaskan North Slope geology: Bakersfield, Calif., Pacific Section, Society of Economic Paleontologists and Mineralogists, Book 50, p. 347-348.

Sainsbury, C.L., 1967, Upper Pleistocene features in the Bering Strait area: U.S. Geological Survey Professional Paper 575-D, p. 203-213.

Sainsbury, C.L., 1969a, Geologic map of the Teller B-4 and southern part of the Teller C-4 quadrangles, western Seward Peninsula, Alaska: U.S. Geological Survey Miscellaneous Investigations Map I-572, scale 1:63,360.

Sainsbury, C.L., 1969b, Geology and ore deposits of the central York Mountains, Seward Peninsula, Alaska: U.S. Geological Survey Bulletin 1287, 101 p., 6 sheets.

Sainsbury, C.L., 1972, Geologic map of the Teller quadrangle, western Seward Peninsula, Alaska: U.S. Geological Survey Miscellaneous Investigations Map I-685, 4 p., scale $1: 250,000$.

Sainsbury, C.L., 1974, Geologic map of the Bendeleben 1:250,000 quadrangle, Seward Peninsula Alaska: Golden, Colo., Air Samplex, 31 p., 1 sheet, scale 1:250,000. [Prepared in cooperation with the U.S. Bureau of Mines, U.S. Geological Survey, and The Mapmakers].

Sainsbury, C.L., Coleman, R.G., and Kachadoorian, R., 1970, Blueschist facies rocks of the Seward Peninsula, Alaska: U.S. Geological Survey Professional Paper 700-B, p. 33-42.

Sainsbury, C.L., Dutro, J.T., Jr., and Churkin, M., 1971, The Ordovician-Silurian boundary in the York Mountains, western Seward Peninsula, Alaska: U.S. Geological Survey Professional Paper 750-C, p. C52-C57.

Sainsbury, C.L., Hummel, C.L., and Hudson, T., 1972, Reconnaissance geologic map of the Nome quadrangles, Seward Peninsula, Alaska: U.S. Geological Survey Open-File Report 543, 22 p., 1 sheet, scale 1:250,000.

Schrader, F.C., 1902, Geologic section of the Rocky Mountains in northern Alaska: Geological Society of America Bulletin, v. 13, p. 233-252.

Shumway, G., Moore, D.G., and Dowling, G.B., 1964, Fairway rock in Bering Strait, in Miller, R.L., ed., Papers in marine geology_Shepard Commemorative Volume: New York, Macmillan and Company, p. 401-407.

Smith, P.S., 1910, Geology and mineral resources of the Solomon and Casadepaga quadrangles, Seward Peninsula, Alaska: U.S. Geological Survey Bulletin 433, 234 p.

Spear, F.S., 1993, Metamorphic phase equilibria and pressuretemperature-time paths: Mineralogical Society of America,
Monograph, p. 351.

Steidtmann, E., and Cathcart, S.H., 1922, Geology of the York tin deposits, Alaska: U.S. Geological Survey Bulletin 733, $130 \mathrm{p}$.

Streckeisen, A., 1976, To each plutonic rock its proper name: Earth Science Reviews, v. 12, p. 1-33.

Sturnick, M.A., 1984, Metamorphic petrology, geothermobarometry and geochronology of the eastern Kigluaik Mountains, Seward Peninsula, Alaska: Fairbanks, University of Alaska, Masters thesis, $175 \mathrm{p}$.

Swanson, S.E., Turner, D.L., Forbes, R.B., and Hopkins, D.M., 1981, Petrology and geochronology of Tertiary and quaternary basalts from the Seward Peninsula, western Alaska Alaska [abs.]: Geologic Survey of America Abstracts with Programs, v. 13, no. 7, p. 563.

Tailleur, I.L., Brosgé, W.P., and Reiser, H.N., 1967 [1968], Palinspastic analysis of Devonian rocks in northwestern Alaska, in Oswald, D.H., ed., International symposium on the Devonian system, v. 2: Calgary, Alberta Society of Petroleum Geologists, p. 1345-1361.

Thurston, S.P., 1985, Structure, petrology, and metamorphic history of the Nome Group blueschist terrane, Salmon Lake area, Seward Peninsula, Alaska: Geological Society of America Bulletin, v. 96, p. 600-617.

Till, A.B., 1980, Crystalline rocks of the Kigluaik Mountains, Seward Peninsula, Alaska: Seattle, Wash., University of Washington, Masters thesis, $92 \mathrm{p}$.

Till, A.B., 1981, Alpine-type garnet lherzolite from the Kigluaik Mountains, Seward Peninsula, Alaska [abs.]: Geologic Society of America Abstracts with Programs, Cordilleran Section, March 25-27, 1981, v. 13, no. 2, p. 110.

Till, A.B., Aleinikoff, J.N., Amato, J.M., and Harris, A.G., 2006, New paleontologic and geochronologic protolith ages for the paleocontinental margin of Arctic Alaska [abs.]: Geological Society of America Abstracts with Programs, v. 38, no. 5 , p. 13.

Till, A.B., Amato, J.M., Aleinikoff, J.N., Dumoulin, J.A., and Bleick, H.A., 2008a, Application of detrital zircon analysis to identify protolith age, basin evolution, potential correlatives, and provenance of penetratively deformed blueschist-facies metasedimentary rocks, northern Alaska [abs.], in Garver, J.I., and Montaria, M.J., eds., Proceedings from the 11th international conference on thermochronometry, Anchorage, Alaska, September 15-19, 2008, p. 236-238, accessed August 1, 2009, at http://minerva.union. $\mathrm{edu} / \mathrm{ft} 2008 /$

Till, A.B., and Dumoulin, J.A., 1994, Seward Peninsula-Geology of Seward Peninsula and Saint Lawrence Island, in Plafker, G., and Berg, H.C., eds., The geology of Alaska: Boulder, Colo., Geological Society of America, The Geology of North America, v. G-1, p. 141-152.

Till, A.B., Dumoulin, J.A., Gamble, B.M., Kaufman, D.S., and Carroll, P.I., 1986, Preliminary geologic map and fossil data, Solomon, Bendeleben, and southern Kotzebue quadrangles, Seward Peninsula, Alaska: U.S. Geological Survey Open-File Report 86-276, 74 p., 3 sheets, scale 1:250,000.

Till, A.B., Dumoulin, J.A., Harris, A.G., Moore, T.E., Bleick, H.A., and Siwiec, B., 2008b, Bedrock geologic map of 
the southern Brooks Range, Alaska, and accompanying conodont data: U.S. Geological Survey Open-File Report 2008-1149, 88 p., 2 sheets, sheet 1, scale 1:500,000; sheet 2, scale 1:600,000.

Till, A.B., Schmidt, J.M., and Nelson, S.W., 1988, Thrust involvement of metamorphic rocks, southwestern Brooks Range, Alaska: Geology, v. 16, p. 930-933.

Till, A.B., Slack, J.F., Ayuso, R.A., Shanks, W.C., III, Dumoulin, J.A., Amato, J.M., Aleinikoff, J.N., and Bleick, H.A., 2007, Setting and origin of base-metal sulfide deposits in the Nome Group, central Seward Peninsula, Alaska [abs.]: Alaska Miners Association 2007 Convention and Trade Show, p. 10, accessed April 6, 2009, at http://www.alaskaminers.org/abstracts2007.pdf

Tolson, R.B., 1987, Structure and stratigraphy of the Hope Basin, southern Chukchi Sea, Alaska, in Scholl, D.W., Grantz, A., and Vedder, J.G., eds., Geology and resource potential of the continental margin of western North America and adjacent ocean basins, Beaufort Sea to Baja California: Houston, Tex., Circum-Pacific Council for Energy and Mineral Resources, p. 59-72.

Toro, J., Burnette, L., Amato, J., Repetski, J.E., and Gehrels, G., 2006, The Mint River fault — an extensional detachment in the York Mountains, Seward Peninsula, Alaska [abs.]: Geological Society of America Abstracts with Programs, v. 38 , no. 5 , p. $84-85$.

Toro, J., Gans, P.B., McClelland, W.C., and Dumitru, T.A., 2002, Deformation and exhumation of the Mount Igikpak region, central Brooks Range, Alaska, in Miller, E.L., Grantz, A., and Klemperer, S.L., eds., Tectonic evolution of the Bering Shelf-Chukchi Sea-Arctic Margin and adjacent landmasses: Geological Society of America Special Paper 360, p. 111-132.

Turner, D.L., Grybeck, D., and Wilson, F.H., [1975?], Radiometric dates from Alaska-A 1975 compilation: Alaska Division of Geological and Geophysical Surveys Special Report 10, 64 p.

Turner, D.L., and Swanson, S.E., 1981, Continental rifting-A new tectonic model for the central Seward Peninsula, in Wescott, E., and Turner, D.L., eds., Geothermal reconnaissance survey of the central Seward Peninsula, Alaska: University of Alaska, Geophysical Institute, Report prepared for the Division of Geothermal Energy of the U.S. Department of Energy, Report 284, p. 7-36.

Vandervoort, D.J., 1985, Stratigraphy, paleoenvironment, and diagenesis of the Lower Ordovician York Mountain carbonates, Seward Peninsula, Alaska: Baton Rouge, Louisiana, Louisiana State University, Masters thesis, $141 \mathrm{p}$.

Watts, K.F., Harris, A.G., Carlson, R.C., Eckstein, M.K., Gruzlovic, P.D., Imm, T.A., Krumhardt, A.P., Lasota, D.K.,
Morgan, S.K., Enos, Paul, Goldstein, R., Dumoulin, J.A., and Mamet, B., 1994, Analysis of reservoir heterogeneities due to shallowing-upward cycles in carbonate rocks of the Upper Mississippian and Pennsylvanian Wahoo Limestone of northeastern Alaska: Department of Energy Report, Contract DE-AC22-89BC14471, 433 p.

Webby, B.D., Cooper, R.A., Bergström, S.M., and Paris, Florentin, 2004, Stratigraphic framework and time slices, in Webby, B.D., Paris, Florentin, Droser, M.L., and Percival, I.G., eds., The great Ordovician biodiversification event: New York, Columbia University Press, p. 41-47.

Werdon, M.B., Newberry, R.J., Szumigala, D.J., Athey, J.E., Freeman, L.K., and Layer, P.W., 2006, Geologic mapping and mineral investigations in the Casadepaga River-Bluff area and implications for the southern Seward Peninsula, Alaska [abs.]: Alaska Miners Association 2006 Annual Convention and Trade Show, p. 3-5, accessed September 20, 2009, at http://www.alaskaminers.org/abstracts2006. pdf

Werdon, M.B., Stevens, D.S.P., Newberry, R.J., Szumigala, D.J., Athey, J.E., and Hicks, S.A., 2005a, Explanatory booklet to accompany geologic, bedrock, and surficial maps of the Big Hurrah and Council areas, Seward Peninsula, Alaska: Alaska Division of Geological and Geophysical Surveys Report of Investigation 2005-1, 24 p.

Werdon, M.B., Stevens, D.S.P., Newberry, R.J., Szumigala, D.J., Athey, J.E., and Hicks, S.A., 2005b, Geologic map of the Big Hurrah area, northern half of the Solomon C-5 quadrangle, Seward Peninsula, Alaska: Alaska Division of Geological and Geophysical Surveys Report of Investigation 2005-1A, 1 sheet, scale 1:50,000.

Werdon, M.B., Szumigala, D.J., Newberry, R.J., Athey, J.E., and Hicks, S.A., 2005c, Major-oxide, minor-oxide, traceelement, geochemical, and non-carbonate carbon data from rocks collected in the Solomon, Bendeleben, and Nome quadrangles, Seward Peninsula, Alaska in 2003 and 2004: Alaska Division of Geological and Geophysical Surveys Raw Data File 2005-2, 46 p.

Wilson, F.H., Shew, Nora, and Du Bois, G.D., 1994, Map and table showing isotopic age data in Alaska, in Plafker, G. and Berg, H.C., eds., The geology of Alaska: Boulder, Colo., Geological Society of America, The Geology of North America, v. G-1, Plate 8; 1 sheet, scale 1:2,500,000.

Wirth, K.R., Grandy, J., Kelley, K., and Sadofsky, S., 2002, Evolution of crust and mantle beneath the Bering Sea region: Evidence from xenoliths and late Cenozoic basalts, in Miller, E.L., Grantz, A., and Klemperer, S.L., eds., Tectonic evolution of the Bering Shelf-Chukchi Sea-Arctic margin and adjacent landmasses: Geological Society of America Special Paper 306, p. 167-193. 
Table 1. Distribution of geologic units in 1:250,000-scale quadrangle maps in the map area [1diagonal overlay pattern]

\begin{tabular}{|c|c|c|c|c|c|c|c|c|c|}
\hline Geologic unit & Nome & Solomon & Bendeleben & Teller & Kotzebue & Shishmaref & Selawik & Candle & Norton Bay \\
\hline \multicolumn{10}{|c|}{ SURFICIAL DEPOSITS } \\
\hline Qs & $\mathrm{X}$ & $\mathrm{X}$ & $\mathrm{X}$ & $\mathrm{X}$ & $\mathrm{X}$ & $\mathrm{x}$ & $\mathrm{x}$ & $\mathrm{x}$ & $\mathrm{x}$ \\
\hline \multicolumn{10}{|c|}{ MESOZOIC AND CENOZOIC IGNEOUS ROCKS } \\
\hline Qlj & --- & --- & $\mathrm{X}$ & --- & ---- & --- & --- & --- & --- \\
\hline QTV & ---- & $\mathrm{x}$ & $\mathrm{X}$ & $\mathrm{X}$ & $\mathrm{X}$ & ---- & $\mathrm{X}$ & $\mathrm{X}$ & ---- \\
\hline TKv & ---- & --- & $\mathrm{x}$ & ---- & --- & ---- & ---- & --- & ---- \\
\hline Ktg & --- & --- & $\mathrm{X}$ & $\mathrm{X}$ & ---- & ---- & ---- & ---- & ---- \\
\hline Kds & $X$ & $X$ & $\mathrm{X}$ & $X$ & ---- & ---- & ---- & ---- & ---- \\
\hline $\mathrm{Kp}$ & ---- & ---- & $X$ & ---- & ---- & ---- & ---- & ---- & ---- \\
\hline Kdi & $X$ & --- & ---- & ---- & ---- & ---- & ---- & ---- & ---- \\
\hline $\mathrm{Kg}$ & $X$ & ---- & $\mathrm{X}$ & $\mathrm{X}$ & ---- & ---- & ---- & ---- & ---- \\
\hline Ks & ---- & ---- & $\mathrm{x}$ & ---- & ---- & ---- & ---- & ---- & ---- \\
\hline Kku & ---- & ---- & $\mathrm{X}$ & ---- & ---- & ---- & ---- & ---- & ---- \\
\hline Kwc & ---- & ---- & $X$ & ---- & ---- & ---- & ---- & ---- & ---- \\
\hline $\mathrm{Kd}$ & ---- & $X$ & $X$ & ---- & ---- & ---- & ---- & ---- & ---- \\
\hline Kkd & ---- & $\mathrm{X}$ & ---- & ---- & ---- & ---- & ---- & ---- & ---- \\
\hline Kkg & ---- & $\mathrm{X}$ & ---- & ---- & ---- & ---- & ---- & ---- & ---- \\
\hline Kkms & ---- & $\mathrm{X}$ & ---- & ---- & ---- & ---- & ---- & ---- & ---- \\
\hline Kkgm & ---- & $X$ & ---- & ---- & ---- & ---- & ---- & ---- & ---- \\
\hline Kbk & ---- & ---- & $X$ & ---- & ---- & ---- & ---- & ---- & ---- \\
\hline Kdc & ---- & $\mathrm{X}$ & ---- & ---- & ---- & ---- & ---- & ---- & ---- \\
\hline Kgr & ---- & ---- & ---- & ---- & ---- & ---- & ---- & $X$ & ---- \\
\hline Ksy & ---- & ---- & ---- & ---- & ---- & ---- & $\mathrm{X}$ & $\mathrm{X}$ & ---- \\
\hline $\mathrm{Kv}$ & ---- & ---- & ---- & ---- & ---- & ---- & $\mathrm{X}$ & $X$ & $\mathrm{X}$ \\
\hline Kgu & $\mathrm{X}$ & $X$ & $\mathrm{X}$ & $\mathrm{X}$ & ---- & ---- & ---- & ---- & ---- \\
\hline \multicolumn{10}{|c|}{ YORK TERRANE } \\
\hline \multicolumn{10}{|c|}{ York Mountains succession } \\
\hline DSI & ---- & --- & --- & $\mathrm{X}$ & ---- & ---- & ---- & --- & ---- \\
\hline sodl & --- & --- & --- & $\mathrm{x}$ & --- & --- & ---- & --- & --- \\
\hline soul & --- & --- & --- & $\mathrm{X}$ & ---- & --- & ---- & ---- & --- \\
\hline Ols & --- & --- & --- & $\mathrm{x}$ & ---- & --- & --- & --- & --- \\
\hline OI & --- & --- & --- & $\mathrm{x}$ & ---- & --- & ---- & ---- & --- \\
\hline Oal & --- & --- & --- & $\mathrm{X}$ & --- & --- & --- & --- & --- \\
\hline \multicolumn{10}{|c|}{ Units with uncertain affinities } \\
\hline $\mathrm{Pz}$ & --- & --- & --- & $\mathrm{X}$ & ---- & --- & --- & --- & --- \\
\hline Ml & --- & --- & ---- & $\mathrm{x}$ & ---- & --- & ---- & ---- & --- \\
\hline Pzgb & --- & --- & --- & $\mathrm{x}$ & --- & --- & ---- & --- & --- \\
\hline OPI & --- & --- & --- & $\mathrm{x}$ & ---- & --- & --- & --- & --- \\
\hline OPt & --- & ---- & ---- & $\mathrm{X}$ & --- & --- & ---- & ---- & ---- \\
\hline OBp & ---- & ---- & ---- & $\mathrm{X}$ & ---- & --- & ---- & ---- & --- \\
\hline \multicolumn{10}{|c|}{ GRANTLEY HARBOR FAULT ZONE } \\
\hline $\mathrm{Pzp}$ & --- & ---- & $\begin{array}{ll}--- \\
\end{array}$ & $\mathrm{X}$ & ---- & ---- & $\begin{array}{ll}--- \\
\end{array}$ & ---- & ---- \\
\hline $\mathrm{PzPI}$ & ---- & --- & ---- & $\mathrm{x}$ & ---- & --- & --- & --- & --- \\
\hline
\end{tabular}


Table 1. Distribution of geologic units in 1:250,000-scale quadrangle maps in the map area.-Continued [1diagonal overlay pattern]

\begin{tabular}{|c|c|c|c|c|c|c|c|c|c|}
\hline Geologic unit & Nome & Solomon & Bendeleben & Teller & Kotzebue & Shishmaref & Selawik & Candle & Norton Bay \\
\hline $\mathrm{PzPt}$ & ---- & ---- & ---- & $\mathrm{x}$ & ---- & ---- & --- & ---- & ---- \\
\hline \multicolumn{10}{|c|}{ NOME COMPLEX } \\
\hline \multicolumn{10}{|c|}{ Layered sequence } \\
\hline Pznp & ---- & ---- & ---- & $\mathrm{X}$ & ---- & ---- & --- & ---- & --- \\
\hline Ds & ---- & $\mathrm{X}$ & $\mathrm{X}$ & $\mathrm{X}$ & --- & --- & --- & --- & --- \\
\hline Dcs & $\mathrm{x}$ & $\mathrm{x}$ & ---- & --- & --- & ---- & ---- & --- & ---- \\
\hline DOx & $\mathrm{X}$ & $\mathrm{X}$ & $\mathrm{X}$ & $\mathrm{X}$ & $\mathrm{X}$ & ---- & $\mathrm{X}$ & $\mathrm{X}$ & $\mathrm{X}$ \\
\hline DOx ${ }^{1}$ & ---- & ---- & ---- & $\mathrm{X}$ & --- & ---- & --- & --- & ---- \\
\hline $\mathrm{Dg}$ & ---- & ---- & $\mathrm{X}$ & --- & --- & ---- & --- & --- & ---- \\
\hline Df & ---- & --- & $\mathrm{x}$ & --- & --- & --- & --- & --- & ---- \\
\hline Ocs & $\mathrm{X}$ & $\mathrm{X}$ & $\mathrm{x}$ & $\mathrm{X}$ & $\mathrm{X}$ & ---- & $\mathrm{X}$ & $\mathrm{X}$ & ---- \\
\hline Oim & $\mathrm{X}$ & $\mathrm{X}$ & $\mathrm{x}$ & $\mathrm{X}$ & $\mathrm{x}$ & ---- & --- & --- & ---- \\
\hline $\mathrm{Pn}$ & $\mathrm{X}$ & $\mathrm{X}$ & $\mathrm{x}$ & ---- & ---- & ---- & --- & --- & --- \\
\hline \multicolumn{10}{|c|}{ Scattered metacarbonate rocks } \\
\hline $\mathrm{Pzm}$ & ---- & $\mathrm{x}$ & $\mathrm{X}$ & $\mathrm{x}$ & $\mathrm{x}$ & --- & --- & $\mathrm{X}$ & $\mathrm{X}$ \\
\hline $\mathrm{Pzd}$ & ---- & --- & $\mathrm{X}$ & --- & $\mathrm{X}$ & ---- & --- & $\mathrm{X}$ & $\mathrm{X}$ \\
\hline Pzmm & $\mathrm{x}$ & --- & ---- & ---- & --- & --- & --- & --- & ---- \\
\hline Ddm & ---- & $\mathrm{x}$ & $\mathrm{X}$ & --- & --- & --- & --- & --- & --- \\
\hline Sd & ---- & --- & $\mathrm{x}$ & --- & --- & --- & --- & --- & ---- \\
\hline Od & ---- & $\mathrm{X}$ & $\mathrm{X}$ & --- & --- & --- & --- & --- & ---- \\
\hline$€ d$ & ---- & $\mathrm{x}$ & ---- & ---- & --- & ---- & --- & --- & ---- \\
\hline \multicolumn{10}{|c|}{ Metaturbidites } \\
\hline Debm & ---- & $\mathrm{x}$ & ---- & --- & --- & --- & --- & --- & $\mathrm{x}$ \\
\hline D€ks & ---- & $\mathrm{x}$ & ---- & ---- & $\mathrm{X}$ & ---- & --- & --- & ---- \\
\hline DObm & ---- & --- & --- & --- & $\mathrm{X}$ & ---- & ---- & ---- & ---- \\
\hline \multicolumn{10}{|c|}{ HIGH-GRADE METAMORPHIC AND ASSOCIATED IGNEOUS ROCKS } \\
\hline $\mathrm{PzBh}$ & $\mathrm{X}$ & $\mathrm{X}$ & $\mathrm{X}$ & $\mathrm{X}$ & --- & ---- & --- & --- & ---- \\
\hline $\mathrm{Pz} \mathrm{Pm}$ & --- & ---- & $\mathrm{x}$ & ---- & ---- & ---- & --- & --- & --- \\
\hline $\mathrm{PzPg}$ & ---- & ---- & $\mathrm{x}$ & --- & $\mathrm{X}$ & ---- & --- & --- & --- \\
\hline Po & $\mathrm{x}$ & $\mathrm{X}$ & $\mathrm{x}$ & $\mathrm{X}$ & --- & ---- & --- & --- & --- \\
\hline $\mathrm{Bv}$ & --- & --- & $\mathrm{x}$ & --- & --- & --- & --- & --- & --- \\
\hline \multicolumn{10}{|c|}{ KUGRUK FAULT ZONE } \\
\hline TKs & ---- & $\mathrm{X}$ & $\mathrm{X}$ & --- & ---- & ---- & ---- & $\mathrm{X}$ & $\mathrm{X}$ \\
\hline $\mathrm{Jt}$ & ---- & --- & $\mathrm{x}$ & --- & --- & --- & --- & --- & --- \\
\hline $\mathrm{MzPzm}$ & --- & $\mathrm{x}$ & $\mathrm{X}$ & --- & $\mathrm{X}$ & --- & --- & $\mathrm{x}$ & --- \\
\hline
\end{tabular}


Table 2. Selected K-Ar, ${ }^{40} \mathrm{Ar} /{ }^{39} \mathrm{Ar}$ and $\mathrm{Rb}-\mathrm{Sr}$ age determinations. (table spans facing page)

[- not reported. See "Remarks" column for details on units within brackets; latitude and longitude given are in North American Datum 1927; Dalrymple (1979); localities are plotted on sheet 2; scale of map precludes labeling of all locality names]

\begin{tabular}{|c|c|c|c|c|c|c|c|c|c|}
\hline \multirow{2}{*}{$\begin{array}{l}\text { Map } \\
\text { no. }\end{array}$} & \multirow[b]{2}{*}{ Field number } & \multirow{2}{*}{$\begin{array}{l}\text { Geologic } \\
\text { unit }\end{array}$} & \multirow{2}{*}{$\begin{array}{l}\text { 1:63,360-scale } \\
\text { quadrangle }\end{array}$} & \multirow[b]{2}{*}{ Locality } & \multicolumn{2}{|c|}{ Lat (N) } & \multicolumn{2}{|c|}{ Long (W) } & \multirow[b]{2}{*}{ Method } \\
\hline & & & & & Deg & Min & Deg & Min & \\
\hline 1 & - & Kgu [water] & - & Fairway Rock & 65 & 37.4 & 168 & 44.5 & $\mathrm{~K}-\mathrm{Ar}$ \\
\hline 2 & DT79P15 & $\mathrm{Kg}[\mathrm{PzPh}]$ & Teller A-1 & Kigluaik Mountains & 65 & 2.5 & 165 & 0.4 & $\mathrm{~K}-\mathrm{Ar}$ \\
\hline 3 & 91T-MR-50A & Ocs & Teller A-2 & Southwest side of Tuksuk Channel & 65 & 9.688 & 165 & 58.354 & ${ }^{40} \mathrm{Ar} /{ }^{39} \mathrm{Ar}$ \\
\hline 4 & 91T-MR-51 & Ocs & Teller A-2 & Northeast side of Tuksuk Channel & 65 & 10.06 & 165 & 54.463 & ${ }^{40} \mathrm{Ar} /{ }^{39} \mathrm{Ar}$ \\
\hline 5 & 91T-MR-38 & Ocs & Teller A-3 & $\begin{array}{l}\text { Northern edge of ridge between Gold Run and } \\
\text { McAdam Creek }\end{array}$ & 65 & 1.627 & 166 & 9.987 & ${ }^{40} \mathrm{Ar} /{ }^{39} \mathrm{Ar}$ \\
\hline 6 & 91T-HD-2b & Ocs & Teller A-3 & Confluence of Skookum Creek and Gold Run & 65 & 2.038 & 166 & 11.742 & ${ }^{40} \mathrm{Ar} /{ }^{39} \mathrm{Ar}$ \\
\hline 7 & 91T-LL-5 & Ocs & Teller A-3 & Headwaters of Alder Creek near Sullivan Camp & 65 & 4.219 & 166 & 6.942 & ${ }^{40} \mathrm{Ar} /{ }^{39} \mathrm{Ar}$ \\
\hline 8 & 91T-LR-18 & Pznp & Teller A-3 & $\begin{array}{l}\text { North side of Right Fork, Bluestone River, } 2.5 \\
\text { miles from the road }\end{array}$ & 65 & 6.257 & 166 & 19.997 & ${ }^{40} \mathrm{Ar} /{ }^{39} \mathrm{Ar}$ \\
\hline 9 & PT80-51D & QTV & Teller B-3 & Eva Mountain & 65 & 21.679 & 166 & 8.468 & $\mathrm{~K}-\mathrm{Ar}$ \\
\hline 10 & РT80-50B & QTv & Teller B-3 & Hill 1220 & 65 & 22.056 & 166 & 9.288 & $\mathrm{~K}-\mathrm{Ar}$ \\
\hline 11 & PT80-50A & QTv & Teller B-3 & Hill 1220 & 65 & 22.056 & 166 & 9.28 & $\mathrm{~K}-\mathrm{Ar}$ \\
\hline 12 & 73Ahp 7 & QTv & Teller B-4 & $\begin{array}{l}\text { Divide between California River and Arctic } \\
\text { Creek }\end{array}$ & 65 & 25.152 & 166 & 32.215 & $\mathrm{~K}-\mathrm{Ar}$ \\
\hline 13 & AK104 & Ktg & Teller B-4 & Black Mountain & 65 & 28.633 & 166 & 44.433 & $\mathrm{~K}-\mathrm{Ar}$ \\
\hline 14 & AK110 & Ktg [Oal] & Teller B-5 & Lost River Mines & 65 & 28.55 & 167 & 9.4 & $\mathrm{~K}-\mathrm{Ar}$ \\
\hline 15 & $\mathrm{PC} 2$ & {$[\mathrm{Ds}]$} & Teller C-1 & Kougarok region & 65 & 42.6 & 165 & 11.4 & $\mathrm{~K}-\mathrm{Ar}$ \\
\hline 16 & $\mathrm{PC} 1$ & {$[\mathrm{Ds}]$} & Teller C-1 & Kougarok region & 65 & 42.6 & 165 & 11.4 & $\mathrm{Rb}-\mathrm{Sr}$ \\
\hline 17 & BB45 & Ktg & Teller C-5 & Brooks Mountain, approximate location & 65 & 31.928 & 167 & 7.534 & $\mathrm{~K}-\mathrm{Ar}$ \\
\hline 18 & AK108 & Ktg & Teller C-7 & Cape Mountain & 65 & 35.8 & 168 & 2.5 & $\mathrm{Rb}-\mathrm{Sr}$ \\
\hline 19 & 77AH8 & Ktg & Teller C-7 & Cape Mountain & 65 & 35.8 & 168 & 2.5 & $\mathrm{~K}-\mathrm{Ar}$ \\
\hline 20 & AK114 & $\mathrm{Ktg}$ & Teller D-3 & Ear Mountain & 65 & 55.1 & 166 & 13.8 & $\mathrm{~K}-\mathrm{Ar}$ \\
\hline 21 & AK112 & $\mathrm{Ktg}$ & Teller D-3 & Ear Mountain & 65 & 55.133 & 166 & 13.8 & $\mathrm{Rb}-\mathrm{Sr}$ \\
\hline 22 & $80-91-2$ & DOx & Nome C-1 & 6.8 miles north of Nome & 64 & 34.7 & 165 & 18.9 & $\mathrm{~K}-\mathrm{Ar}$ \\
\hline 23 & $04 Z 641$ & Dcs & Nome C-1 & Rock Creek, approximate location & 64 & 36.9 & 165 & 24.9 & ${ }^{40} \mathrm{Ar} /{ }^{39} \mathrm{Ar}$ \\
\hline 24 & $\begin{array}{l}04 Z 638 A \\
\text { WM\#2 }\end{array}$ & Dcs & Nome C-1 & Rock Creek, approximate location & 64 & 36.9 & 165 & 24.9 & ${ }^{40} \mathrm{Ar} /{ }^{39} \mathrm{Ar}$ \\
\hline
\end{tabular}




\begin{tabular}{lllll}
\hline \multicolumn{1}{c}{ Mineral } & $\begin{array}{c}\text { Age } \\
\text { (Ma) }\end{array}$ & $\begin{array}{c}\text { Error } \\
\text { (Ma) }\end{array}$ & \multicolumn{1}{c}{ Rock type } & \multicolumn{1}{c}{ Reference } \\
\hline Biotite & 110.7 & 3 & Granite & Shumway and others, 1964 \\
& & & & \\
Biotite & 83.4 & 2.5 & Gneissic granite & Turner and Swanson, 1981 \\
White mica & 124.3 & 0.3 & Schist & Hannula and McWilliams, 1995 \\
White mica & 114.8 & 0.7 & Schist & Hannula and McWilliams, 1995 \\
White mica & 118.1 & 0.3 & Schist & Hannula and McWilliams, 1995 \\
White mica & 116.2 & 0.3 & Schist & Hannula and McWilliams, 1995 \\
White mica & 120.5 & 0.2 & Schist & Hannula and McWilliams, 1995 \\
White mica & 119.9 & 0.3 & Schist & Hannula and McWilliams, 1995 \\
Whole-rock & 2.6 & 0.2 & Basalt & Turner and Swanson, 1981
\end{tabular}

Whole-rock $2.5 \quad 0.3 \quad$ Basalt

$\begin{array}{llll}\text { Whole-rock } & 2.7 & 0.2 & \text { Basalt }\end{array}$

Whole-rock $2.92 \quad 0.14 \quad$ Basalt

\begin{tabular}{|c|c|c|c|c|}
\hline Biotite & 79.1 & 2.9 & Granite & Hudson and Arth, 1983 \\
\hline Biotite & 80.2 & 3 & Granite & Hudson and Arth, 1983 \\
\hline Mica & 70.2 & - & Granite & $\begin{array}{l}\text { Puchner, C.C., written commun. } \\
1986\end{array}$ \\
\hline- & 72 & - & $\begin{array}{l}\text { Porphyritic biotite } \\
\text { granite }\end{array}$ & $\begin{array}{l}\text { Puchner, C.C., written commun. } \\
1986\end{array}$ \\
\hline Biotite & 77 & 3 & Granite & Sainsbury, 1969b \\
\hline $\begin{array}{l}\text { Whole-rock } \\
\text { (multiple) }\end{array}$ & 72.5 & 2 & Granite & Hudson and Arth, 1983 \\
\hline Biotite & 78.8 & 2.9 & Granite & Hudson and Arth, 1983 \\
\hline Biotite & 76.7 & 2.8 & Granite & Hudson and Arth, 1983 \\
\hline $\begin{array}{l}\text { Whole-rock } \\
\text { (multiple) }\end{array}$ & 73.1 & 1.6 & Granite & Hudson and Arth, 1983 \\
\hline Phengite & 162 & 6 & Pelitic schist & Armstrong and others, 1986 \\
\hline White mica & 102.3 & 0.7 & Vein & Layer and Newberry, 2004 \\
\hline White mica & 112.3 & 0.8 & Vein & Layer and Newberry, 2004 \\
\hline
\end{tabular}

\section{Remarks}

Age recalculated with 1976 constants; authors' reported age 108 $\pm 3.0 \mathrm{Ma}$; sample is from an outcrop of Kgu that is too small to show at map scale; given the latitude and longitude the sample plots on the shoreline in the water

Location from Wilson and others (1994)

Age given is authors' reported weighted mean plateau age

Age given is authors' reported weighted mean plateau age

Age given is authors' reported weighted mean plateau age

Age given is authors' reported weighted mean plateau age

Age given is authors' reported weighted mean plateau age

Age given is authors' reported weighted mean plateau age

Authors' comments: sample is a volcanic neck from the basalt flows; authors' reported location of sample is north of Teller at "Eva Mountain." Latitude and longitude were not reported and were determined based on authors' description and fig. 8

Authors' comments: sample is a volcanic neck from the basalt flows; authors reported location of sample is north of Teller at "Hill 1220." Latitude and longitude were not reported and were determined based on authors' description and fig. 8

Authors' comments: sample is a volcanic neck from the basalt flows; authors reported location of sample is north of Teller at "Hill 1220." Latitude and longitude were not reported and were determined based on authors' description and fig. 8

Age recalculated with 1976 constants; authors' reported age 2.84 $\pm 0.14 \mathrm{Ma}$; authors' reported location of the sample is "the divide between California River and Arctic Creek." Latitude and longitude were not reported and were determined based on authors' description, fig. 3, and additional description on p. 447

Location based on authors' table 1

Sample is from an outcrop of Ktg that is too small to show at map scale; given the latitude and longitude the sample plots in $\mathrm{Oal}$

Sample is from drill core that is in Ds at the surface

Sample is from drill core that is in Ds at the surface

Age recalculated with 1976 constants; Author's reported age 75.1 $\pm 3.0 \mathrm{Ma}$; sample number is given in Turner and others, 1975

Whole rock / isochron age; location based on authors' table 1

Location based on authors' table 1

Location based on authors' table 1

Whole rock / isochron age; location based on authors' table 1

Authors' reported comments: low-grade pelitic schist

Age given is the authors' reported plateau age; sample is from drill core

Age given is the authors' reported plateau age; sample is from drill core 
Table 2. Selected K-Ar, 40Ar/39Ar and Rb-Sr age determinations.-Continued (table spans facing page)

[- not reported. See "Remarks" column for details on units within brackets; latitude and longitude given are in North American Datum 1927; Dalrymple (1979); localities are plotted on sheet 2; scale of map precludes labeling of all locality names]

\begin{tabular}{|c|c|c|c|c|c|c|c|c|c|}
\hline \multirow{2}{*}{$\begin{array}{c}\text { Map } \\
\text { no. }\end{array}$} & \multirow[b]{2}{*}{ Field number } & \multirow{2}{*}{$\begin{array}{l}\text { Geologic } \\
\text { unit }\end{array}$} & \multirow{2}{*}{$\begin{array}{c}\text { 1:63,360-scale } \\
\text { quadrangle }\end{array}$} & \multirow[b]{2}{*}{ Locality } & \multicolumn{2}{|c|}{ Lat (N) } & \multicolumn{2}{|c|}{ Long (W) } & \multirow[b]{2}{*}{ Method } \\
\hline & & & & & Deg & Min & Deg & Min & \\
\hline 25 & $90 \mathrm{AG} 025$ & Dike $[\mathrm{Pzmm}]$ & Nome C-3 & $\begin{array}{l}\text { Approximately } 9.5 \text { miles due north of Sinuk (at } \\
\text { the mouth of Sinuk River) and } 5 \text { miles east of } \\
\text { Bering Sea }\end{array}$ & 64 & 43.837 & 166 & 18.614 & $\mathrm{~K}-\mathrm{Ar}$ \\
\hline 26 & $80-41-4$ & Ocs & Nome D-1 & 3.3 miles southwest of Salmon Lake & 64 & 51 & 165 & 8.5 & $\mathrm{~K}-\mathrm{Ar}$ \\
\hline 27 & $90 \mathrm{P} 8-13 \mathrm{~b}$ & $\mathrm{PzPh}$ & Nome D-1 & Kigluaik Mountains & 64 & 53.567 & 165 & 27.817 & ${ }^{40} \mathrm{Ar} /{ }^{39} \mathrm{Ar}$ \\
\hline 28 & $90 \mathrm{~J} 11-5$ & $\mathrm{Pzh}$ & Nome D-1 & Kigluaik Mountains & 64 & 59.633 & 165 & 24.8 & ${ }^{40} \mathrm{Ar} /{ }^{39} \mathrm{Ar}$ \\
\hline 29 & $92.4 \mathrm{~A}-115$ & Dike $[\mathrm{PzEh}]$ & Nome D-2 & Kigluaik Mountains & 64 & 53.11 & 165 & 48.93 & ${ }^{40} \mathrm{Ar} /{ }^{39} \mathrm{Ar}$ \\
\hline 30 & $92.3 \mathrm{~A}-101$ & Dike $[\mathrm{Kgu}]$ & Nome D-2 & Kigluaik pluton and associated dikes & 64 & 54.584 & 165 & 44.026 & ${ }^{40} \mathrm{Ar} /{ }^{39} \mathrm{Ar}$ \\
\hline 31 & $92.2 \mathrm{~A}-40$ & Dike [Eo] & Nome D-2 & Kigluaik pluton and associated dikes & 64 & 54.967 & 165 & 37.133 & ${ }^{40} \mathrm{Ar} /{ }^{39} \mathrm{Ar}$ \\
\hline 32 & $92.2 \mathrm{~A}-40$ & Dike [Eo] & Nome D-2 & Kigluaik pluton and associated dikes & 64 & 54.967 & 165 & 37.133 & ${ }^{40} \mathrm{Ar} /{ }^{39} \mathrm{Ar}$ \\
\hline 33 & $92.2 \mathrm{~A}-46$ & Dike [Eo] & Nome D-2 & Kigluaik Mountains & 64 & 55.09 & 165 & 36.2 & ${ }^{40} \mathrm{Ar} /{ }^{39} \mathrm{Ar}$ \\
\hline 34 & $90 \mathrm{P} 8-4 \mathrm{~A}$ & Po & Nome D-2 & Kigluaik Mountains & 64 & 55.183 & 165 & 31.817 & ${ }^{40} \mathrm{Ar} /{ }^{39} \mathrm{Ar}$ \\
\hline 35 & $90 \mathrm{P} 12-4 \mathrm{~b}$ & Po & Nome D-2 & Kigluaik Mountains & 64 & 55.3 & 165 & 32.571 & ${ }^{40} \mathrm{Ar} /{ }^{39} \mathrm{Ar}$ \\
\hline 36 & $90 \mathrm{~K} 12-7 \mathrm{a}$ & Po & Nome D-2 & Kigluaik Mountains & 64 & 55.3 & 165 & 33.05 & ${ }^{40} \mathrm{Ar} /{ }^{39} \mathrm{Ar}$ \\
\hline 37 & $90 \mathrm{~K} 12-7 \mathrm{~b}$ & Dike [Ro] & Nome D-2 & Kigluaik Mountains & 64 & 55.53 & 165 & 33.05 & ${ }^{40} \mathrm{Ar} /{ }^{39} \mathrm{Ar}$ \\
\hline 38 & $90 \mathrm{P} 12-5 \mathrm{~b}$ & Po & Nome D-2 & Kigluaik Mountains & 64 & 55.717 & 165 & 32 & ${ }^{40} \mathrm{Ar} /{ }^{39} \mathrm{Ar}$ \\
\hline 39 & $924 \mathrm{~A}-120$ & Kdi & Nome D-2 & Kigluaik pluton and associated dikes & 64 & 56.183 & 165 & 47.45 & ${ }^{40} \mathrm{Ar} /{ }^{39} \mathrm{Ar}$ \\
\hline 40 & $924 \mathrm{~A}-119$ & Kdi & Nome D-2 & Kigluaik pluton and associated dikes & 64 & 57.2 & 165 & 46.1 & ${ }^{40} \mathrm{Ar} /{ }^{39} \mathrm{Ar}$ \\
\hline 41 & 89S-LMC-47 & $\mathrm{Pzh}$ & Nome D-3 & Kigluaik Mountains & 64 & 50.583 & 166 & 2.817 & ${ }^{40} \mathrm{Ar} /{ }^{39} \mathrm{Ar}$ \\
\hline 42 & $89 \mathrm{MC}-78$ & Dike $[\mathrm{PzPh}]$ & Nome D-3 & Kigluaik Mountains & 64 & 53.09 & 166 & 0.59 & ${ }^{40} \mathrm{Ar} /{ }^{39} \mathrm{Ar}$ \\
\hline 43 & $68 \mathrm{AMm} 285$ & $\mathrm{Kd}$ & $\begin{array}{l}\text { Bendeleben } \\
\text { A-1 }\end{array}$ & Darby pluton & 65 & 0.865 & 162 & 13.503 & $\mathrm{~K}-\mathrm{Ar}$ \\
\hline 44 & $84 \mathrm{AGe} 79$ & Kwc & Bendeleben A-2 & Windy Creek pluton & 65 & 8.748 & 162 & 34.518 & $\mathrm{~K}-\mathrm{Ar}$ \\
\hline 45 & 90S-EK-9 & $\mathrm{Pz} h$ & Bendeleben A-6 & Kigluaik Mountains & 65 & 0.094 & 164 & 47.047 & ${ }^{40} \mathrm{Ar} /{ }^{39} \mathrm{Ar}$ \\
\hline
\end{tabular}




\begin{tabular}{|c|c|c|c|c|}
\hline Mineral & $\begin{array}{c}\text { Age } \\
\text { (Ma) }\end{array}$ & $\begin{array}{l}\text { Error } \\
\text { (Ma) }\end{array}$ & Rock type & Reference \\
\hline Biotite & 80.5 & 0.8 & Granitic & Shew, N., written commun., \\
\hline Phengite & 141 & 5 & Schist & Armstrong and others, 1986 \\
\hline White mica & 83.7 & 0.5 & $\begin{array}{l}\text { Metapelite or } \\
\text { orthogneiss }\end{array}$ & Calvert and others, 1999 \\
\hline Biotite & 83.9 & 0.4 & $\begin{array}{l}\text { Orthogneiss or } \\
\text { paraorthogneiss }\end{array}$ & Calvert and others, 1999 \\
\hline Whole rock & 83.3 & 0.9 & Diabase dikes & Amato and others, $2003 \mathrm{c}$ \\
\hline Biotite & 82.5 & 0.3 & Dike & Calvert and others, 1999 \\
\hline Hornblende & 82.8 & 0.4 & Dike & Calvert and others, 1999 \\
\hline Biotite & 82.1 & 0.3 & Dike & Calvert and others, 1999 \\
\hline Whole rock & 81.3 & 0.6 & Diabase dikes & Amato and others, $2003 \mathrm{c}$ \\
\hline Biotite & 83.9 & 0.4 & $\begin{array}{l}\text { Orthogneiss or } \\
\text { paraorthogneiss }\end{array}$ & Calvert and others, 1999 \\
\hline Hornblende & 86.4 & 0.7 & Amphibolite & Calvert and others, 1999 \\
\hline
\end{tabular}

\begin{tabular}{|c|c|c|c|c|}
\hline Hornblende & 86.1 & 0.4 & Amphibolite & Calvert and others, 1999 \\
\hline Biotite & 83.6 & 0.8 & Diabase dikes & Amato and others, $2003 \mathrm{c}$ \\
\hline Hornblende & 85.6 & 0.4 & $\begin{array}{l}\text { Granodioritic } \\
\text { orthogneiss }\end{array}$ & Calvert and others, 1999 \\
\hline Hornblende & 82 & 0.3 & $\begin{array}{l}\text { Mafic phase igne- } \\
\text { ous rock }\end{array}$ & Calvert and others, 1999 \\
\hline Hornblende & 82.2 & 0.3 & $\begin{array}{l}\text { Mafic phase igne- } \\
\text { ous rock }\end{array}$ & Calvert and others, 1999 \\
\hline White mica & 83.1 & 0.5 & $\begin{array}{l}\text { Metapelite or } \\
\text { orthogneiss }\end{array}$ & Calvert and others, 1999 \\
\hline Whole rock & 79.2 & 0.3 & Diabase dike & Amato and others, $2003 \mathrm{c}$ \\
\hline Biotite & 94.4 & 2.9 & Quartz monzonite & $\begin{array}{l}\text { Miller and others, 1972; Miller and } \\
\text { Bunker, } 1976\end{array}$ \\
\hline Hornblende & 93.8 & 2.1 & Monzogranite & Shew, N., written commun., 1987 \\
\hline Biotite & 83.8 & 1.1 & $\begin{array}{l}\text { Orthogneiss or } \\
\text { paraorthogneiss }\end{array}$ & Calvert and others, 1999 \\
\hline
\end{tabular}

\section{Remarks}

Analyst's reported location is on "one of the many northwest trending ridges (boundary of section 5 and 8 , T9S, R38W Kateel River meridian); elevation about 450 feet;" analyst's reported latitude and longitude: $64^{\circ} 43^{\prime} 50^{\prime \prime} \mathrm{N}$ and $166^{\circ} 18^{\prime} 30^{\prime \prime} \mathrm{W}$; sample is from a granitic dike in Pzmm that is too small to show at map scale

Authors' reported comments: low-grade pelitic schist

Age given is authors' reported plateau age; authors reported "white mica separates from metapelite and orthogneiss"

Age given is authors' reported plateau age; authors reported "biotites from orthogneisses and paraorthogneisses"

Age given is the authors' reported weighted mean plateau age; sample is from a diabase dike in $\mathrm{P}_{\mathbf{Z}} \mathrm{Ph}$ that is too small to show at map scale

Age given is authors' reported plateau age; location given is based on authors' fig. 4

Age given is authors' reported plateau age; location given is from authors' table 1; authors' reported sample number: 922A-40

Age given is authors' reported plateau age; location given is from authors' table 1

Age given is the authors' reported weighted mean plateau age; sample is from a diabase dike in Po that is too small to show at map scale

Age given is authors' reported plateau age; authors reported "biotites from orthogneisses and paraorthogneisses;" Location given is from authors' table 1

Age given is authors' reported plateau age; authors reported the sample is from a "penetratively deformed amphibolite;" authors' reported location of $60^{\circ} 8^{\prime} 4^{\prime \prime}$ and $-165^{\circ} 31^{\prime} 49^{\prime \prime}$ is mislocated; location given is based on authors' fig. 4

Age given is authors' reported plateau age; authors reported the sample is from a "penetratively deformed amphibolite;" location given is from authors' table 1

Age given is the authors' reported weighted mean plateau age; sample is from a diabase dike outcrop in Po that is too small to show at map scale

Age given is authors' reported plateau age; authors reported the sample is from a "melt-filled extension fracture along a syntectonic shear band in a granodioritic orthogneiss"

Age given is authors' reported plateau age; location given is from authors' table 1

Age given is authors' reported plateau age; location given is from authors' table 1

Age given is authors' reported plateau age; authors reported "white mica separates from metapelite and orthogneiss"; location given is from authors' table 1

Age given is a weighted mean plateau age; sample is from a diabase dike in $\mathrm{Pz}$ Eh that is too small to show at map scale

Age recalculated with 1976 constants; authors' reported age 92.1 $\pm 2.8 \mathrm{Ma}$; reported latitude and longitude $65^{\circ} 01^{\prime} \mathrm{N}$ and $162^{\circ} 11^{\prime}$ $\mathrm{W}$

Analyst reported that the sample is "an intrusive between Windy Creek and an unnamed northern tributary of Mosquito Creek. Sample was collected from the flat portion of ridge, approximately 490 meters south of peak 2764"

Age given is authors' reported plateau age; authors' reported "biotites from orthogneisses and paraorthogneisses;" location given is based on authors' fig. 4 
Table 2. Selected K-Ar, 40Ar/39Ar and Rb-Sr age determinations.-Continued (table spans facing page)

[- not reported. See "Remarks" column for details on units within brackets; latitude and longitude given are in North American Datum 1927; Dalrymple (1979); localities are plotted on sheet 2; scale of map precludes labeling of all locality names]

\begin{tabular}{|c|c|c|c|c|c|c|c|c|c|}
\hline \multirow{2}{*}{$\begin{array}{l}\text { Map } \\
\text { no. }\end{array}$} & \multirow[b]{2}{*}{ Field number } & \multirow{2}{*}{$\begin{array}{l}\text { Geologic } \\
\text { unit }\end{array}$} & \multirow{2}{*}{$\begin{array}{l}\text { 1:63,360-scale } \\
\text { quadrangle }\end{array}$} & \multirow[b]{2}{*}{ Locality } & \multicolumn{2}{|c|}{ Lat (N) } & \multicolumn{2}{|c|}{ Long (W) } & \multirow[b]{2}{*}{ Method } \\
\hline & & & & & Deg & Min & Deg & Min & \\
\hline 46 & 92NA-107 & Dike $[\mathrm{PzEh}]$ & Bendeleben A-6 & Kigluaik Mountains & 65 & 0.43 & 164 & 49.95 & ${ }^{40} \mathrm{Ar} /{ }^{39} \mathrm{Ar}$ \\
\hline 47 & $83 \mathrm{MS} 119 \mathrm{~b}$ & Po & Bendeleben A-6 & Eastern Kigluaik Mountains & 65 & 0.8 & 164 & 56.7 & $\mathrm{~K}-\mathrm{Ar}$ \\
\hline 48 & $83 \mathrm{MS} 119 \mathrm{~b}$ & Po & Bendeleben A-6 & Eastern Kigluaik Mountains & 65 & 0.8 & 164 & 56.7 & $\mathrm{~K}-\mathrm{Ar}$ \\
\hline 49 & 89S-MC-54 & $\mathrm{PzPh}$ & Bendeleben A-6 & Kigluaik Mountains & 65 & 1.548 & 164 & 47.799 & ${ }^{40} \mathrm{Ar} /{ }^{39} \mathrm{Ar}$ \\
\hline 50 & 90-Hens & en & Bendeleben A-6 & Hen and Chickens Mountain & 65 & 8.067 & 164 & 51.067 & ${ }^{40} \mathrm{Ar} /{ }^{39} \mathrm{Ar}$ \\
\hline 51 & PS80-14A & Dike $[\mathrm{Pz} \mathrm{Eh}]$ & Bendeleben A-6 & $\begin{array}{l}\text { Westernmost Bendeleben Mountains, approxi- } \\
\text { mate location }\end{array}$ & 65 & 10.536 & 164 & 39.075 & $\mathrm{~K}-\mathrm{Ar}$ \\
\hline 52 & PT80-28 & Kgu & Bendeleben A-6 & $\begin{array}{l}\text { Westernmost Bendeleben Mountains, approxi- } \\
\text { mate location }\end{array}$ & 65 & 10.649 & 164 & 38.617 & $\mathrm{~K}-\mathrm{Ar}$ \\
\hline \multirow[t]{2}{*}{53} & PT $80-30$ & Kgu & Bendeleben A-6 & $\begin{array}{l}\text { Westernmost Bendeleben Mountains, approxi- } \\
\text { mate location }\end{array}$ & 65 & 10.649 & 164 & 38.617 & $\mathrm{~K}-\mathrm{Ar}$ \\
\hline & DT79P1 & - & - & $\begin{array}{l}\text { Kigluaik Mountains and Hen and Chickens } \\
\text { Mountain }\end{array}$ & - & - & - & - & $\mathrm{K}-\mathrm{Ar}$ \\
\hline \multirow[t]{3}{*}{54} & DT79P4 & en & Bendeleben A-6 & Hen and Chickens Mountain & 65 & 8.3 & 164 & 54.6 & $\mathrm{~K}-\mathrm{Ar}$ \\
\hline & DT79P11A & - & - & $\begin{array}{l}\text { Kigluaik Mountains and Hen and Chickens } \\
\text { Mountain }\end{array}$ & - & - & - & - & $\mathrm{K}-\mathrm{Ar}$ \\
\hline & DT79P13 & - & - & $\begin{array}{l}\text { Kigluaik Mountains and Hen and Chickens } \\
\text { Mountain }\end{array}$ & - & - & - & - & $\mathrm{K}-\mathrm{Ar}$ \\
\hline 55 & DT79P14 & - & Bendeleben A-6 & Kigluaik Mountains & 65 & 1 & 164 & 59.1 & $\mathrm{~K}-\mathrm{Ar}$ \\
\hline 56 & $68 \mathrm{AMm} 280$ & Kbk & Bendeleben B-2 & Bendeleben pluton & 65 & 16 & 162 & 55 & $\mathrm{~K}-\mathrm{Ar}$ \\
\hline 57 & $83 \mathrm{AGe} 90$ & Kbk & Bendeleben B-3 & Kuzitrin pluton & 65 & 23.3 & 163 & 6.2 & $\mathrm{~K}-\mathrm{Ar}$ \\
\hline 58 & 84AKn106 & QTv & Bendeleben B-4 & Minnie Creek & 65 & 24.566 & 163 & 47.432 & $\mathrm{~K}-\mathrm{Ar}$ \\
\hline 59 & $84 \mathrm{AKn} 106 \mathrm{a}$ & QTv & Bendeleben B-4 & Minnie Creek & 65 & 24.566 & 163 & 47.432 & $\mathrm{~K}-\mathrm{Ar}$ \\
\hline 60 & $84 \mathrm{AKn} 106 \mathrm{a}$ & QTV & Bendeleben B-4 & Minnie Creek & 65 & 24.566 & 163 & 47.432 & $\mathrm{~K}-\mathrm{Ar}$ \\
\hline 61 & $84 \mathrm{AKn} 106 \mathrm{c}$ & QTV & Bendeleben B-4 & Minnie Creek & 65 & 24.566 & 163 & 47.432 & $\mathrm{~K}-\mathrm{Ar}$ \\
\hline 62 & $84 \mathrm{AKn} 106 \mathrm{c}$ & QTV & Bendeleben B-4 & Minnie Creek & 65 & 24.566 & 163 & 47.432 & $\mathrm{~K}-\mathrm{Ar}$ \\
\hline 63 & 87AHP26 & QTV & Bendeleben B-4 & Minnie Creek & 65 & 24.566 & 163 & 47.432 & $\mathrm{~K}-\mathrm{Ar}$ \\
\hline
\end{tabular}




\begin{tabular}{|c|c|c|c|c|c|}
\hline Mineral & $\begin{array}{l}\text { Age } \\
\text { (Ma) }\end{array}$ & $\begin{array}{l}\text { Error } \\
\text { (Ma) }\end{array}$ & Rock type & Reference & Remarks \\
\hline Whole rock & 82.4 & 1.3 & Diabase dike & Amato and others, $2003 \mathrm{c}$ & $\begin{array}{l}\text { Age given is the authors' reported weighted mean plateau age; } \\
\text { sample is from a diabase dike in Pzh that is too small to show at } \\
\text { map scale }\end{array}$ \\
\hline Biotite & 84.9 & 2.5 & Mafic gneiss & Sturnick, 1984 & Location based on author's table 1 \\
\hline Hornblende & 85.6 & 2.6 & Mafic gneiss & Sturnick, 1984 & Location based on author's table 1 \\
\hline White mica & 83 & 0.8 & $\begin{array}{l}\text { Metapelite or } \\
\text { orthogneiss }\end{array}$ & Calvert and others, 1999 & $\begin{array}{l}\text { Age given is authors' reported plateau age; authors' reported } \\
\text { "white mica separates from metapelite and orthogneiss;" Loca- } \\
\text { tion given is based on authors' sample location in fig. } 4\end{array}$ \\
\hline Biotite & 84.7 & 0.2 & $\begin{array}{l}\text { Orthogneiss or } \\
\text { paraorthogneiss }\end{array}$ & Calvert and others, 1999 & $\begin{array}{l}\text { Age given is authors' reported plateau age; authors' reported } \\
\text { "biotites from orthogneisses and paraorthogneisses" }\end{array}$ \\
\hline Whole-rock & 74.9 & 3 & Basalt dike & Turner and Swanson, 1981 & $\begin{array}{l}\text { Authors' reported comments: basalt dike intruding Precambrian } \\
\text { basement; location approximated based on authors' fig. } 5\end{array}$ \\
\hline Whole-rock & 74.5 & 2.8 & Rhyolite & Turner and Swanson, 1981 & $\begin{array}{l}\text { Authors' reported comments: small dike / plug of vesicular } \\
\text { rhyolite intruding Precambrian basement; location given is based } \\
\text { on authors' fig. } 5\end{array}$ \\
\hline Whole-rock & 69 & 2.6 & Rhyolite & Turner and Swanson, 1981 & $\begin{array}{l}\text { Authors' reported comments: small dike / plug of vesicular } \\
\text { rhyolite intruding Precambrian basement; location given is based } \\
\text { on authors' fig. } 5\end{array}$ \\
\hline Biotite & 83.9 & 2.5 & Schist & Turner and Swanson, 1981 & $\begin{array}{l}\text { Authors' reported location of the samples is "metamorphic } \\
\text { and igneous intrusive rocks from the Kigluaik Mountains and } \\
\text { Hen and Chickens Mountain." Latitude and longitude were not } \\
\text { reported }\end{array}$ \\
\hline Hornblende & 84.9 & 2.6 & Amphibolite & Turner and Swanson, 1981 & Location from Wilson and others (1994) \\
\hline Biotite & 81.4 & 2.4 & Pelitic gneiss & Turner and Swanson, 1981 & $\begin{array}{l}\text { Authors' reported location of the samples is "metamorphic } \\
\text { and igneous intrusive rocks from the Kigluaik Mountains and } \\
\text { Hen and Chickens Mountain." Latitude and longitude were not } \\
\text { reported }\end{array}$ \\
\hline Biotite & 87 & 2.6 & Gneissic granite & Turner and Swanson, 1981 & $\begin{array}{l}\text { Authors' reported location of the samples is "metamorphic } \\
\text { and igneous intrusive rocks from the Kigluaik Mountains and } \\
\text { Hen and Chickens Mountain." Latitude and longitude were not } \\
\text { reported }\end{array}$ \\
\hline Biotite & 83 & 2.5 & Granodiorite & Turner and Swanson, 1981 & Location from Wilson and others (1994) \\
\hline Biotite & 81.8 & 2.5 & Quartz monzonite & $\begin{array}{l}\text { Miller and others, 1972; Miller and } \\
\text { Bunker, } 1976\end{array}$ & $\begin{array}{l}\text { Age recalculated with } 1976 \text { constants; authors' reported age } 79.8 \\
\pm 2.4 \mathrm{Ma}\end{array}$ \\
\hline Biotite & 83 & 1.4 & Monzogranite & Till and others, 1986 & Location based on authors' table 2 \\
\hline Plagioclase & 0.81 & 0.09 & Basalt & Kaufman and others, 1991 & $\begin{array}{l}\text { Location given based on authors' fig. } 2 \text {, on sh. } 2 \text { and reported } \\
\text { location on "the right bank of Minnie Creek, where the river } \\
\text { is diverted westward by the lava"; age was first reported in } \\
\text { Kaufman and Hopkins ( } 1985 \text { ) with reported location } 65^{\circ} 31^{\prime} \text { and } \\
-164^{\circ} 09^{\prime} \text {; that location appears to be incorrect based on location } \\
\text { given in Kaufman and others (1991) fig. } 2 \text {, on sh. } 2\end{array}$ \\
\hline Whole rock & 0.024 & 0.11 & Basalt & Kaufman and others, 1991 & $\begin{array}{l}\text { Location given based on authors' fig. } 2 \text {, on sh. } 2 \text { and reported } \\
\text { location on "the right bank of Minnie Creek, where the river is } \\
\text { diverted westward by the lava" }\end{array}$ \\
\hline Whole rock & 0.1 & 0.16 & Basalt & Kaufman and others, 1991 & $\begin{array}{l}\text { Location given based on authors' fig. } 2 \text {, on sh. } 2 \text { and reported } \\
\text { location on "the right bank of Minnie Creek, where the river is } \\
\text { diverted westward by the lava" }\end{array}$ \\
\hline Whole rock & 0.717 & 0.11 & Basalt & Kaufman and others, 1991 & $\begin{array}{l}\text { Location given based on authors' fig. } 2 \text {, on sh. } 2 \text { and reported } \\
\text { location on "the right bank of Minnie Creek, where the river is } \\
\text { diverted westward by the lava" }\end{array}$ \\
\hline Whole rock & 0.719 & 0.13 & Basalt & Kaufman and others, 1991 & $\begin{array}{l}\text { Location given based on authors' fig. } 2 \text {, on sh. } 2 \text { and reported } \\
\text { location on "the right bank of Minnie Creek, where the river is } \\
\text { diverted westward by the lava" }\end{array}$ \\
\hline Whole rock & 0.797 & 0.06 & Basalt & Kaufman and others, 1991 & $\begin{array}{l}\text { Location given based on authors' fig. } 2 \text {, on sh. } 2 \text { and reported } \\
\text { location on "the right bank of Minnie Creek, where the river is } \\
\text { diverted westward by the lava" }\end{array}$ \\
\hline
\end{tabular}


Table 2. Selected K-Ar, 40Ar/39Ar and Rb-Sr age determinations.-Continued (table spans facing page) [- not reported. See "Remarks" column for details on units within brackets; latitude and longitude given are in North American Datum 1927; Dalrymple (1979); localities are plotted on sheet 2; scale of map precludes labeling of all locality names]

\begin{tabular}{|c|c|c|c|c|c|c|c|c|c|}
\hline \multirow{2}{*}{$\begin{array}{l}\text { Map } \\
\text { no. }\end{array}$} & \multirow[b]{2}{*}{ Field number } & \multirow{2}{*}{$\begin{array}{l}\text { Geologic } \\
\text { unit }\end{array}$} & \multirow{2}{*}{$\begin{array}{l}\text { 1:63,360-scale } \\
\text { quadrangle }\end{array}$} & \multirow[b]{2}{*}{ Locality } & \multicolumn{2}{|c|}{ Lat (N) } & \multicolumn{2}{|c|}{ Long (W) } & \multirow[b]{2}{*}{ Method } \\
\hline & & & & & Deg & Min & Deg & Min & \\
\hline 64 & 84AKn106d & QTV & Bendeleben B-4 & Minnie Creek & 65 & 24.566 & 163 & 47.432 & $\mathrm{~K}-\mathrm{Ar}$ \\
\hline 65 & 68AMm324 & Kku & Bendeleben C-2 & Kugruk pluton, approximate location & 65 & 41.94 & 162 & 35.97 & $\mathrm{~K}-\mathrm{Ar}$ \\
\hline 66 & PT80-34 & QTV & Bendeleben $\mathrm{C}-2$ & $\begin{array}{l}\text { Imuruk basalts: Gosling series, approximate } \\
\text { location }\end{array}$ & 65 & 33.062 & 162 & 57.242 & $\mathrm{~K}-\mathrm{Ar}$ \\
\hline 67 & PT80-36A & QTv & Bendeleben C-2 & $\begin{array}{l}\text { Imuruk basalts: Gosling series, approximate } \\
\text { location }\end{array}$ & 65 & 33.062 & 162 & 57.242 & $\mathrm{~K}-\mathrm{Ar}$ \\
\hline 68 & PT80-37 & QTv & Bendeleben $\mathrm{C}-2$ & $\begin{array}{l}\text { Imuruk basalts: Kugruk series, approximate } \\
\text { location }\end{array}$ & 65 & 33.885 & 162 & 55.776 & $\mathrm{~K}-\mathrm{Ar}$ \\
\hline 69 & PT80-38 & QTv & Bendeleben $\mathrm{C}-2$ & $\begin{array}{l}\text { Imuruk basalts: Kugruk series, approximate } \\
\text { location }\end{array}$ & 65 & 33.885 & 162 & 55.776 & $\mathrm{~K}-\mathrm{Ar}$ \\
\hline 70 & PT80-40 & QTV & Bendeleben C-2 & $\begin{array}{l}\text { Imuruk basalts: Kugruk series, approximate } \\
\text { location }\end{array}$ & 65 & 33.885 & 162 & 55.776 & $\mathrm{~K}-\mathrm{Ar}$ \\
\hline 71 & PT80-35A & QTv & Bendeleben C-2 & $\begin{array}{l}\text { Imuruk basalts: Imuruk series, approximate } \\
\text { location }\end{array}$ & 65 & 33.188 & 162 & 57.865 & $\mathrm{~K}-\mathrm{Ar}$ \\
\hline 72 & PT80-33 & QTV & Bendeleben C-2 & $\begin{array}{l}\text { Imuruk basalts: Imuruk series, approximate } \\
\text { location }\end{array}$ & 65 & 33.188 & 162 & 57.865 & $\mathrm{~K}-\mathrm{Ar}$ \\
\hline 73 & $85 \mathrm{AGe} 43$ & Ks (overlay) & Bendeleben C-3 & Nimrod Hill & 65 & 37.614 & 163 & 5.736 & $\mathrm{~K}-\mathrm{Ar}$ \\
\hline 74 & $83 \mathrm{AGe} 124 \mathrm{a}$ & Ks (overlay) & Bendeleben C-3 & Virginia Butte stock & 65 & 42.833 & 163 & 8.65 & $\mathrm{~K}-\mathrm{Ar}$ \\
\hline 75 & 83AGe117 & Ks (overlay) & Bendeleben C-3 & Asses Ears stock & 65 & 44.5 & 163 & 10.8 & $\mathrm{~K}-\mathrm{Ar}$ \\
\hline 76 & $80-19-4$ & Ocs & Bendeleben C-6 & $\begin{array}{l}\text { Left Fork Kougarok River flows into Kougarok } \\
\text { River }\end{array}$ & 65 & 31 & 164 & 42.9 & $\mathrm{~K}-\mathrm{Ar}$ \\
\hline 77 & $83 \mathrm{AGe} 126$ & Ks (overlay) & Bendeleben D-3 & Crossfox Butte stock & 65 & 47.283 & 163 & 17.35 & $\mathrm{~K}-\mathrm{Ar}$ \\
\hline 78 & AHP66 & QTv [Qs] & Bendeleben D-3 & $\begin{array}{l}\text { Lava Camp Mine in the upper Inmachuk River } \\
\text { Valley }\end{array}$ & 65 & 53.1 & 163 & 7.5 & $\mathrm{~K}-\mathrm{Ar}$ \\
\hline 79 & 69AH228 & Ktg & Bendeleben D-6 & Oonatut Granite Complex & 65 & 50 & 164 & 35 & $\mathrm{~K}-\mathrm{Ar}$ \\
\hline
\end{tabular}




\begin{tabular}{|c|c|c|c|c|}
\hline Mineral & $\begin{array}{l}\text { Age } \\
\text { (Ma) }\end{array}$ & $\begin{array}{l}\text { Error } \\
\text { (Ma) }\end{array}$ & Rock type & Reference \\
\hline Whole rock & 1.748 & 0.57 & Basalt & Kaufman and others, 1991 \\
\hline Biotite & 94.8 & 2.8 & $\begin{array}{l}\text { Quartz monzonite } \\
\text { to quartz monzo- } \\
\text { diorite }\end{array}$ & Till and others, 1986 \\
\hline Whole-rock & 0.82 & 0.08 & Basalt & Turner and Swanson, 1981 \\
\hline Whole-rock & 0.91 & 0.09 & Basalt & Turner and Swanson, 1981 \\
\hline Whole-rock & 26.4 & 1.4 & Basalt & Turner and Swanson, 1981 \\
\hline Whole-rock & 28.1 & 1.4 & Basalt & Turner and Swanson, 1981 \\
\hline Whole-rock & 28.8 & 1.8 & Basalt & Turner and Swanson, 1981 \\
\hline Whole-rock & 2.2 & 0.2 & Basalt & Turner and Swanson, 1981 \\
\hline Whole-rock & 2.2 & 0.2 & Basalt & Turner and Swanson, 1981 \\
\hline Hornblende & 96.3 & 2 & Monzonite & Shew, N., written commun., 1990 \\
\hline Biotite & 94.8 & 1.9 & Syenite & Till and others, 1986 \\
\hline Biotite & 96.2 & 1.6 & Monzogranite & Till and others, 1986 \\
\hline Phengite & 156 & 5 & Pelitic schist & Armstrong and others, 1986 \\
\hline Biotite & 91.5 & 2.8 & $\begin{array}{l}\text { Monzogranite to } \\
\text { quartz monzonite }\end{array}$ & Till and others, 1986 \\
\hline Whole-rock & 5.83 & 0.2 & Basalt & Hopkins and others, 1971 \\
\hline
\end{tabular}
series" after Hopkins' (1963) Gosling volcanics. Latitude and longitude were not reported. Based on Turner's and Swanson's description, location was approximated using Hopkins' (1963) fig. 9

Authors' reported location of sample is "Imuruk basalts: Gosling series" after Hopkins' (1963) Gosling volcanics. Latitude and longitude were not reported. Based on Turner's and Swanson's description, location was approximated using Hopkins' (1963) fig. 9

Authors' reported location of sample is "Imuruk basalts: Kugruk series" after Hopkins' (1963) Kugruk volcanics. Latitude and longitude were not reported and were determined based on the type locality in the canyon of the Kugruk River, 3 miles east of Imuruk Lake (Hopkins, 1963, fig. 9 and p. C48)

Authors' reported location of sample is "Imuruk basalts: Kugruk series" after Hopkins' (1963) Kugruk volcanics. Latitude and longitude were not reported and were determined based on the type locality in the canyon of the Kugruk River, 3 miles east of Imuruk Lake (Hopkins, 1963, fig. 9 and p. C48)

Authors' reported location of sample is "Imuruk basalts: Kugruk series" after Hopkins' (1963) Kugruk volcanics. Latitude and longitude were not reported and were determined based on the type locality in the canyon of the Kugruk River, 3 miles east of Imuruk Lake (Hopkins, 1963, fig. 9 and p. C48)

Authors' reported location of sample is "Imuruk basalts: Imuruk series" after Hopkins' (1963) Kugruk volcanics. Latitude and longitude were not reported and were determined based on the type locality in the canyon of the Kugruk River, 3 miles east of Imuruk Lake (Hopkins, 1963, fig. 9 and p. C48)

Authors' reported location of sample is "Imuruk basalts: Imuruk series" after Hopkins' (1963) Kugruk volcanics. Latitude and longitude were not reported and were determined based on the type locality in the canyon of the Kugruk River, 3 miles east of Imuruk Lake (Hopkins, 1963, fig. 9 and p. C48)

Analyst's reported location of sample is "small ridge NW [northwest] of x2995 (summit of Mount Arathlatuluk); sample collected from flat section of ridge, approx. 1/3 mile from the summit"

Location based on authors' table 2

Location based on authors' table 2

Authors' reported comments: low-grade pelitic schist

Authors' reported comments: some biotite was chloritized, and this age should be considered suspect

Age recalculated with 1976 constants; authors' reported age 5.7 $\pm 0.2 \mathrm{Ma}$; authors' reported comments: sample collected from the roof of the Lava Camp Mine tholeiitic basalt; sample number provided by authors' as AHP66 in table 2 is a subsample of 66AHP 22 (stated in authors' table 1).

Age recalculated with 1976 constants; author's reported age 67.5 $\pm 2 \mathrm{Ma}$; latitude and longitude not reported; location of sample is approximate 
Table 2. Selected K-Ar, 40Ar/39Ar and Rb-Sr age determinations.-Continued (table spans facing page)

[- not reported. See "Remarks" column for details on units within brackets; latitude and longitude given are in North American Datum 1927; Dalrymple (1979); localities are plotted on sheet 2; scale of map precludes labeling of all locality names]

\begin{tabular}{|c|c|c|c|c|c|c|c|c|c|}
\hline \multirow{2}{*}{$\begin{array}{l}\text { Map } \\
\text { no. }\end{array}$} & \multirow[b]{2}{*}{ Field number } & \multirow{2}{*}{$\begin{array}{c}\text { Geologic } \\
\text { unit }\end{array}$} & \multirow{2}{*}{$\begin{array}{c}\text { 1:63,360-scale } \\
\text { quadrangle }\end{array}$} & \multirow[b]{2}{*}{ Locality } & \multicolumn{2}{|c|}{ Lat (N) } & \multicolumn{2}{|c|}{ Long (W) } & \multirow[b]{2}{*}{ Method } \\
\hline & & & & & Deg & Min & Deg & Min & \\
\hline 80 & $69 \mathrm{AH} 283$ & $\mathrm{Ktg}$ & Bendeleben D-6 & Oonatut Granite Complex & 65 & 51 & 164 & 42 & $\mathrm{~K}-\mathrm{Ar}$ \\
\hline 81 & 70AMm150 & Kkms & Solomon C-2 & Kachauik pluton & 64 & 34 & 162 & 45 & $\mathrm{~K}-\mathrm{Ar}$ \\
\hline 82 & 71AGk259 & Dike $[\mathrm{Kkg}]$ & Solomon C-2 & Kachauik dike swarm & 64 & 43.5 & 162 & 53.1 & $\mathrm{~K}-\mathrm{Ar}$ \\
\hline 83 & BLC-15-89 & {$[\mathrm{Ddm}]$} & Solomon C-4 & Bluff & 64 & 34.058 & 163 & 40.274 & ${ }^{40} \mathrm{Ar} /{ }^{39} \mathrm{Ar}$ \\
\hline 84 & BLC-15-107 & {$[\mathrm{Ddm}]$} & Solomon C-4 & Koyana Creek - Bluff area & 64 & 34.058 & 163 & 40.274 & ${ }^{40} \mathrm{Ar} /{ }^{39} \mathrm{Ar}$ \\
\hline 85 & BLC-30-212.2 & {$[\mathrm{DOx}]$} & Solomon C-4 & Koyana Creek - Bluff area & 64 & 34.46 & 163 & 42.775 & ${ }^{40} \mathrm{Ar} /{ }^{39} \mathrm{Ar}$ \\
\hline 86 & $\begin{array}{l}\text { 04RN500C } \\
\text { WM\#2 }\end{array}$ & Dcs & Solomon C-5 & $\begin{array}{l}\text { Headwaters of Big Hurrah Creek, } 3.8 \text { miles east } \\
\text { of Uncle Sam Mountain }\end{array}$ & 64 & 37.807 & 164 & 8.568 & ${ }^{40} \mathrm{Ar} /{ }^{39} \mathrm{Ar}$ \\
\hline 87 & 04SH119A & DOx & Solomon C-5 & Road cut 0.2 miles south of the East Fork bridge & 64 & 41.435 & 164 & 16.839 & ${ }^{40} \mathrm{Ar} /{ }^{39} \mathrm{Ar}$ \\
\hline 88 & 04RN319A & DOx & Solomon C-5 & Road cut 0.2 miles south of the East Fork bridge & 64 & 41.435 & 164 & 16.839 & ${ }^{40} \mathrm{Ar} /{ }^{39} \mathrm{Ar}$ \\
\hline 89 & 04MBW384C & Dike $[\mathrm{DOx}]$ & Solomon C-5 & $\begin{array}{l}\text { Hill slope } 0.8 \text { mile north of where Goodenough } \\
\text { Cr. flows into Solomon River East Fork }\end{array}$ & 64 & 42.616 & 164 & 10.949 & ${ }^{40} \mathrm{Ar} /{ }^{39} \mathrm{Ar}$ \\
\hline 90 & $04 \mathrm{Z} 156$ & DOx & Solomon C-5 & $\begin{array}{l}\text { Hill slope } 0.7 \text { mile northwest of where Butte } \\
\text { Creek flows into Solomon River East Fork }\end{array}$ & 64 & 43.232 & 164 & 20.571 & ${ }^{40} \mathrm{Ar} /{ }^{39} \mathrm{Ar}$ \\
\hline 91 & 04RN351B & Dcs & Solomon C-5 & Confluence of Rock Creek with Coal Creek & 64 & 44.602 & 164 & 14.53 & ${ }^{40} \mathrm{Ar} /{ }^{39} \mathrm{Ar}$ \\
\hline 92 & 70AMm158B & $\mathrm{Kd}$ & Solomon D-1 & Darby pluton & 64 & 45.2 & 162 & 25.2 & $\mathrm{~K}-\mathrm{Ar}$ \\
\hline 93 & 70AMm158B & $\mathrm{Kd}$ & Solomon D-1 & Darby pluton & 64 & 45.2 & 162 & 25.2 & $\mathrm{~K}-\mathrm{Ar}$ \\
\hline 94 & 70AMm415A & $\mathrm{Kd}$ & Solomon D-1 & Darby pluton & 64 & 57 & 162 & 20 & $\mathrm{~K}-\mathrm{Ar}$ \\
\hline 95 & 70AMm45 & Kkg & Solomon D-2 & Kachauik pluton, summit of Mt. Kachauik & 64 & 45.878 & 162 & 51.878 & $\mathrm{~K}-\mathrm{Ar}$ \\
\hline 96 & 85ATi43 & Kgu & Solomon D-2 & $1 / 3$ mile northwest Mt. Arathlatuluk & 64 & 49.467 & 162 & 33.833 & $\mathrm{~K}-\mathrm{Ar}$ \\
\hline 97 & 70AMm218 & Kdc (overlay) & Solomon D-2 & Dry Canyon stock, Darby Mountains & 64 & 53.58 & 162 & 42.556 & $\mathrm{~K}-\mathrm{Ar}$ \\
\hline 98 & 04RN318A & $\mathrm{DOx}$ & Solomon D-4 & $\begin{array}{l}\text { Hill slope } 1.7 \text { miles north of where Goldbottom } \\
\text { Creek flows into Niukluk River }\end{array}$ & 64 & 57.676 & 163 & 56.412 & ${ }^{40} \mathrm{Ar} /{ }^{39} \mathrm{Ar}$ \\
\hline 99 & 04RN355C & Dcs & Solomon D-5 & $\begin{array}{l}\text { Coal Creek, } 0.8 \text { miles downstream from Rock } \\
\text { Creek }\end{array}$ & 64 & 45.113 & 164 & 15.866 & ${ }^{40} \mathrm{Ar} /{ }^{39} \mathrm{Ar}$ \\
\hline 100 & 83MS 92 & Ocs & Solomon D-6 & 4.2 miles northeast of Salmon Lake & 64 & 57.1 & 164 & 50.8 & $\mathrm{~K}-\mathrm{Ar}$ \\
\hline 101 & 83MS 132 & Ocs & Solomon D-6 & 4.8 miles northeast of Salmon Lake & 64 & 57.8 & 164 & 50.6 & $\mathrm{~K}-\mathrm{Ar}$ \\
\hline 102 & $61 \mathrm{ATg} 40$ & Ksy & Candle C-6 & Western Candle quadrangle & 65 & 41 & 161 & 31 & $\mathrm{~K}-\mathrm{Ar}$ \\
\hline 103 & - & Ksy & Candle B-4 & Granite Mountain & 65 & 25.7 & 161 & 13 & $\mathrm{~K}-\mathrm{Ar}$ \\
\hline
\end{tabular}




\begin{tabular}{|c|c|c|c|c|c|}
\hline Mineral & $\begin{array}{l}\text { Age } \\
\text { (Ma) }\end{array}$ & $\begin{array}{l}\text { Error } \\
\text { (Ma) }\end{array}$ & Rock type & Reference & Remarks \\
\hline Biotite & 71.1 & 2 & Granite & Hudson, 1979 & $\begin{array}{l}\text { Age recalculated with } 1976 \text { constants; author's reported age } 69.4 \\
\pm 2 \text { Ma; latitude and longitude not reported; location of sample is } \\
\text { approximate }\end{array}$ \\
\hline Hornblende & 99.3 & 3 & Monzonite & Miller and others, 1972 & $\begin{array}{l}\text { Age recalculated with } 1976 \text { constants; authors' reported age } 97.5 \\
\pm 3 \mathrm{Ma}\end{array}$ \\
\hline Biotite & 96.2 & 3 & $\begin{array}{l}\text { Nepheline syenite } \\
\text { dike }\end{array}$ & Miller and others, 1972 & $\begin{array}{l}\text { Age recalculated with } 1976 \text { constants; authors' reported age } 93.9 \\
\pm 3.0 \mathrm{Ma} \text {; sample is from an outcrop of a nepheline syenite dike } \\
\text { in Kkg that is too small to show at map scale }\end{array}$ \\
\hline White mica & 109.1 & 0.7 & $\begin{array}{l}\text { Quartz-muscovite } \\
\text { schist }\end{array}$ & Ford and Snee, 1996 & $\begin{array}{l}\text { Age given is the authors' reported plateau age; sample is from } \\
\text { drill core that is in Ddm at the surface }\end{array}$ \\
\hline White mica & 109.6 & 0.2 & $\begin{array}{l}\text { Quartz-muscovite } \\
\text { schist }\end{array}$ & Ford and Snee, 1996 & $\begin{array}{l}\text { Age given is the authors' reported plateau age; sample is from } \\
\text { drill core that is in Ddm at the surface }\end{array}$ \\
\hline White mica & 109.1 & 0.2 & Auriferous veins & Ford and Snee, 1996 & $\begin{array}{l}\text { Age given is the authors' reported plateau age; sample is from } \\
\text { drill core that is in DOx at the surface }\end{array}$ \\
\hline White mica & 117.7 & 1 & $\begin{array}{l}\text { Quartz-plagioclase- } \\
\text { ankerite-white } \\
\text { mica vein/breccia }\end{array}$ & Layer and Newberry, 2004 & $\begin{array}{l}\text { Age given is the authors' reported plateau age; location given in } \\
\text { Werdon and others, } 2005 \mathrm{c}\end{array}$ \\
\hline Biotite & 107.2 & 0.6 & Alkalic dike & Layer and Newberry, 2004 & $\begin{array}{l}\text { Age given is the authors' reported plateau age; location given in } \\
\text { Werdon and others, } 2005 \mathrm{c}\end{array}$ \\
\hline White mica & 107.5 & 0.7 & $\begin{array}{l}\text { Quartz-white mica } \\
\text { vein }\end{array}$ & Layer and Newberry, 2004 & $\begin{array}{l}\text { Age given is the authors' reported plateau age; location given in } \\
\text { Werdon and others, } 2005 \mathrm{c}\end{array}$ \\
\hline Biotite & 83.9 & 0.3 & Mafic dike & Layer and Newberry, 2004 & $\begin{array}{l}\text { Age given is the authors' reported plateau age; authors' reported } \\
\text { comments: unrelated to mineralization; location given by M. } \\
\text { Werdon, written commun., } 2008\end{array}$ \\
\hline White mica & 112.8 & 0.3 & Vein & Layer and Newberry, 2004 & $\begin{array}{l}\text { Age given is the authors' reported plateau age; location given by } \\
\text { Werdon, M., written commun., } 2008\end{array}$ \\
\hline White mica & 107.7 & 0.6 & $\begin{array}{l}\text { Quartz-ankerite- } \\
\text { white mica-plagio- } \\
\text { clase vein }\end{array}$ & Layer and Newberry, 2004 & $\begin{array}{l}\text { Age given is the authors' reported plateau age; location given in } \\
\text { Werdon and others, } 2005 \mathrm{c}\end{array}$ \\
\hline Biotite & 90.5 & 1.5 & Quartz monzonite & Miller and others, 1972 & $\begin{array}{l}\text { Age recalculated with } 1976 \text { constants; authors' reported age } 88.3 \\
\pm 1.5 \mathrm{Ma}\end{array}$ \\
\hline Hornblende & 94.6 & 2.7 & Quartz monzonite & Miller and others, 1972 & $\begin{array}{l}\text { Age recalculated with } 1976 \text { constants; authors' reported age } 92.8 \\
\pm 2.6 \mathrm{Ma}\end{array}$ \\
\hline Biotite & 96.4 & 3 & Quartz monzonite & Miller and Bunker, 1976 & $\begin{array}{l}\text { Age recalculated with } 1976 \text { constants; authors' reported age } 94.0 \\
\pm 3 \mathrm{Ma}\end{array}$ \\
\hline Hornblende & 88.2 & 3 & Quartz monzonite & Miller and Bunker, 1976 & $\begin{array}{l}\text { Age recalculated with } 1976 \text { constants; authors' reported age } 86.1 \\
\pm 3 \mathrm{Ma}\end{array}$ \\
\hline Biotite & 102.6 & 1.4 & Granite & Till, A., unpub. data & $\begin{array}{l}\text { Collector's comments: biotite granite that contains sillimanite and } \\
\text { garnet along with biotite }\end{array}$ \\
\hline Hornblende & 108 & 3 & Foyaite & Miller, 1972 & $\begin{array}{l}\text { Age recalculated with } 1976 \text { constants; author's reported age } 105 \\
\pm 3 \mathrm{Ma} \text {; authors' reported latitude and longitude } 64^{\circ} 53^{\prime} \mathrm{N} \text { and } \\
162^{\circ} 42^{\prime} \mathrm{W}\end{array}$ \\
\hline Amphibole & 138.6 & 1 & Vein & Layer and Newberry, 2005 & $\begin{array}{l}\text { Age given is the authors' reported plateau age; location given by } \\
\text { Werdon, M., written commun., } 2008\end{array}$ \\
\hline White mica & 106.5 & 0.8 & $\begin{array}{l}\text { Quartz-plagioclase- } \\
\text { white mica vein }\end{array}$ & Layer and Newberry, 2005 & $\begin{array}{l}\text { Age given is the authors' reported plateau age; location given in } \\
\text { Werdon and others, } 2005 \mathrm{c}\end{array}$ \\
\hline Muscovite & 156.4 & 4.7 & Albitic schist & Sturnick, 1984 & Location based on author's table 1 \\
\hline Muscovite & 152.2 & 4.6 & Albitic schist & Sturnick, 1984 & Location based on author's table 1 \\
\hline Hornblende & 105 & 5 & Quartz monzonite & Patton, 1967 & $\begin{array}{l}\text { Age recalculated with } 1976 \text { constants; author's reported age } 102 \\
\pm 5 \mathrm{Ma} \text {; author's reported latitude and longitude of } 65^{\circ} 41 \text { and } \\
161^{\circ} 31^{\prime} \text { is assumed to be an approximate location }\end{array}$ \\
\hline Hornblende & 108.6 & 3 & Monzonite & Miller, 1972 & $\begin{array}{l}\text { Age recalculated with } 1976 \text { constants; author's reported age } 106 \\
\pm 3 \mathrm{Ma} \text {; authors' reported latitude and longitude } 65^{\circ} 27^{\prime} \mathrm{N} \text { and } \\
161^{\circ} 13^{\prime} \mathrm{W} \text { is assumed to be approximate location }\end{array}$ \\
\hline
\end{tabular}


Table 3. Selected U-Pb zircon analyses. (table spans facing page)

[- not reported. See "Remarks" column for details on units within brackets; latitude and longitude given are in North American Datum 1927; Microprobe and TIMS-Thermal Ionization Mass Spectrometry]

\begin{tabular}{|c|c|c|c|c|c|c|c|c|c|}
\hline \multirow[b]{2}{*}{$\begin{array}{c}\text { Map } \\
\text { no. }\end{array}$} & \multirow[b]{2}{*}{$\begin{array}{c}\text { Field } \\
\text { number }\end{array}$} & \multirow[b]{2}{*}{ Regional belt or assemblage } & \multirow[b]{2}{*}{$\begin{array}{c}\text { Geologic } \\
\text { unit }\end{array}$} & \multirow[b]{2}{*}{ Quadrangle } & \multirow[b]{2}{*}{ Locality } & \multicolumn{2}{|c|}{ Lat (N) } & \multicolumn{2}{|c|}{ Long (W) } \\
\hline & & & & & & Deg & Min & Deg & Min \\
\hline 1 & SP90-6 & $\begin{array}{l}\text { High-grade metamorphic and associ- } \\
\text { ated igneous rocks }\end{array}$ & $\mathrm{Pz}$ Ph & Teller A-1 & Kigluaik foliated syenite & 65 & 0.251 & 165 & 18.991 \\
\hline 2 & 03JT23 & York terrane & $\mathrm{Pzgb}[\mathrm{OPt}]$ & Teller C-5 & York Mountains & 65 & 34.323 & 167 & 26.327 \\
\hline 3 & 05ATi10A & Nome Complex & en & Nome C-1 & Basin Creek & 64 & 40.399 & 165 & 14.073 \\
\hline 4 & $87 \mathrm{SB} 65-5$ & Nome Complex & en & Nome D-1 & Salmon Lake & 64 & 54.41 & 165 & 6.4 \\
\hline 5 & 89SB69-1 & $\begin{array}{l}\text { High-grade metamorphic and associ- } \\
\text { ated igneous rocks }\end{array}$ & Po & Nome D-1 & Thompson Creek & 64 & 56.816 & 165 & 15.433 \\
\hline 6 & - & $\begin{array}{l}\text { High-grade metamorphic and associ- } \\
\text { ated igneous rocks }\end{array}$ & Po & Nome D-1 & Thompson Creek & 64 & 56.816 & 165 & 15.433 \\
\hline 7 & APK92-19 & Nome Complex & Pn & Nome D-1 & Dorothy Creek & 64 & 48.512 & 165 & 16.639 \\
\hline 8 & $92.4 \mathrm{~A}-119$ & Mesozoic and Cenozoic igneous rocks & Kdi & Nome D-2 & Kigluaik granodiorite & 64 & 57.233 & 165 & 46.433 \\
\hline 9 & $92.4 \mathrm{~A}-120$ & Mesozoic and Cenozoic igneous rocks & Kdi & Nome D-2 & Kigluaik granodiorite & 64 & 56.15 & 165 & 48.083 \\
\hline 10 & 05D2-R28a & Nome Complex & $\mathrm{Dg}[\mathrm{DOx}]$ & Bendeleben A-1 & $\begin{array}{l}\text { Small body near north end of } \\
\text { Darby pluton }\end{array}$ & 65 & 1.719 & 162 & 21.059 \\
\hline 11 & 84Age79 & Nome Complex & Kwc & Bendeleben A-2 & Windy Creek pluton & 65 & 8.712 & 162 & 34.8 \\
\hline 12 & 04MBW-935a & $\begin{array}{l}\text { High-grade metamorphic and associ- } \\
\text { ated igneous rocks }\end{array}$ & ev & Bendeleben A-4 & Bendeleben Mountains & 65 & 7.933 & 163 & 56.986 \\
\hline 13 & 04MBW-935a & $\begin{array}{l}\text { High-grade metamorphic and associ- } \\
\text { ated igneous rocks }\end{array}$ & ev & Bendeleben A-4 & Southern Bendeleben & 65 & 7.933 & 163 & 56.986 \\
\hline 14 & - & Mesozoic and Cenozoic igneous rocks & $\mathrm{Kp}$ & Bendeleben A-4 & Pargon pluton & 65 & 11.373 & 163 & 41.243 \\
\hline 15 & 03SP-15 & Nome Complex & en & Bendeleben A-6 & $\begin{array}{l}\text { Small body north of Kigluaik } \\
\text { Mountains }\end{array}$ & 65 & 7.92 & 164 & 49.799 \\
\hline 16 & 05ATi8A & Nome Complex & Df & Bendeleben B-1 & Near Kiwalik Mountain & 65 & 28.183 & 162 & 17.617 \\
\hline 17 & - & Mesozoic and Cenozoic igneous rocks & $\mathrm{Kbk}[\mathrm{Pz} \mathrm{Bh}]$ & Bendeleben B-2 & Bendeleben pluton & 65 & 14.92 & 163 & 8.46 \\
\hline 18 & 81ATi159 & Nome Complex & $\mathrm{Dg}$ & Bendeleben C-1 & Kiwalik Mountain & 65 & 30.05 & 162 & 11.55 \\
\hline \multirow[t]{2}{*}{19} & 84AGe164 & Kugruk fault zone & $\mathrm{Jt}$ & Bendeleben C-4 & Spruce Creek & 65 & 31.342 & 162 & 36.139 \\
\hline & - & $\begin{array}{l}\text { High-grade metamorphic and associ- } \\
\text { ated igneous rocks }\end{array}$ & $\mathrm{Pzh}$ & - & Bendeleben Mountains & - & - & - & - \\
\hline 20 & APK92-1 & Nome Complex & en & Solomon B-6 & Cape Nome & 64 & 26.325 & 164 & 59.886 \\
\hline 21 & $\begin{array}{l}\text { RA-AK-05- } \\
11\end{array}$ & Nome Complex & en & Solomon B-6 & Cape Nome & 64 & 26.325 & 164 & 59.886 \\
\hline 22 & 85ATi118 & $\begin{array}{l}\text { High-grade metamorphic and associ- } \\
\text { ated igneous rocks }\end{array}$ & $\mathrm{Kd}$ & Solomon D-1 & Darby pluton & 64 & 48.222 & 162 & 27.6 \\
\hline 23 & 85ATi43 & $\begin{array}{l}\text { High-grade metamorphic and associ- } \\
\text { ated igneous rocks }\end{array}$ & Kgu & Solomon D-2 & Mount Arathlatuluk & 64 & 49.476 & 162 & 33.6 \\
\hline
\end{tabular}




\begin{tabular}{|c|c|c|c|c|c|}
\hline $\begin{array}{c}\text { Mineral } \\
\text { dated }\end{array}$ & $\begin{array}{l}\text { Interpreted } \\
\text { age } \\
\text { (Ma) }\end{array}$ & $\begin{array}{l}\text { Interpreted } \\
\text { age error } \\
\text { (Ma) 2-sigma }\end{array}$ & Rock type & Reference & Remarks \\
\hline Zircon & 110 & 5 & Metasyenite & Amato and Wright, 1998 & $\begin{array}{l}\text { Analysis by W. McClelland; Location approximated } \\
\text { from fig. } 2 \text {, on sh. } 2 \text { in Amato and Wright, } 1998\end{array}$ \\
\hline Zircon & 541 & 6 & Gabbro & Amato and others, 2006 & $\begin{array}{l}\text { Location provided by collector; Sample is from a } \\
\text { Pzgb outcrop that is too small to show at map scale }\end{array}$ \\
\hline Zircon & 669 & 5 & Orthogneiss & Till and others, 2006 & Latitude and longitude based on 05ATi10(A-D) \\
\hline Zircon & 678 & 4 & Felsic orthogneiss & Amato and Wright, 1998 & Age analysis by TIMS \\
\hline Zircon & 555 & 15 & Orthogneiss & Amato and Wright, 1998 & Age analysis by TIMS \\
\hline Zircon & 565 & 6 & Orthogneiss & Amato, 2004 & $\begin{array}{l}\text { Author reports } 565 \pm 6 \mathrm{Ma} \text { is the average of three } \\
206 \mathrm{~Pb} / 238 \mathrm{U} \text { ages; Age analysis by SHRIMP }\end{array}$ \\
\hline Zircon & 681 & 3 & Orthogneiss & Patrick and McClelland, 1995 & $\begin{array}{l}\text { Location approximated from a map in Patrick and } \\
\text { McClelland, } 1995\end{array}$ \\
\hline Zircon & 89 & 1 & $\begin{array}{l}\text { Hornblende biotite } \\
\text { granodiorite }\end{array}$ & Amato and Wright, 1998 & $\begin{array}{l}\text { Age analysis by TIMS; Location provided by } \\
\text { authors }\end{array}$ \\
\hline Zircon & 91 & 1 & $\begin{array}{l}\text { Hornblende biotite } \\
\text { granodiorite }\end{array}$ & Amato and Wright, 1998 & $\begin{array}{l}\text { Age analysis by TIMS; Location provided by } \\
\text { authors }\end{array}$ \\
\hline Zircon & 390 & 3 & Orthogneiss & Jeff Amato, written comm. 2008 & $\begin{array}{l}\text { Age analysis by SHRIMP; Location provided by } \\
\text { collector; Sample is from a small body of Dg that is } \\
\text { too small to show at map scale }\end{array}$ \\
\hline Zircon & 96.5 & 0.2 & Quartz monzonite & Richard Friedman, written comm., 2009 & Age analysis by TIMS \\
\hline Zircon & 870 & 6 & Metarhyolite & Gottlieb and Amato, 2007 & $\begin{array}{l}\text { Authors' written comm. 2008: rock type is metar- } \\
\text { hyolite; Age analysis by SHRIMP }\end{array}$ \\
\hline Monazite & 86 & 1 & Metarhyolite & Gottlieb and Amato, 2007 & $\begin{array}{l}\text { Authors' reported comments: cooling age and rock } \\
\text { type is metarhyolite; Age analysis by SHRIMP }\end{array}$ \\
\hline Zircon & 86 & 1 & Granite & Gottlieb and Amato, 2008 & Approximate location; Age analysis by SHRIMP \\
\hline Zircon & 687 & 9 & Orthogneiss & Jeff Amato, written comm. 2008 & Age analysis by SHRIMP \\
\hline Zircon & 392 & 5 & Metafelsite & Till and others, 2006 & Latitude and longitude based on 05ATi8(A-D) \\
\hline Zircon & 104 & 1 & $\begin{array}{l}\text { Foliated biotite } \\
\text { granite }\end{array}$ & Gottlieb and Amato, 2008 & $\begin{array}{l}\text { Age analysis by SHRIMP; sample is from margin of } \\
\text { Bendeleben pluton as mapped by collector }\end{array}$ \\
\hline Zircon & 391 & 3 & $\begin{array}{l}\text { Granitic orthog- } \\
\text { neiss }\end{array}$ & Till and others, 2006 & Location is the same as $05 \mathrm{ATi} 7$ \\
\hline Zircon & 163 & 3 & Tonalite & John Aleinikoff, written comm., 1986 & - \\
\hline Zircon & 390 & - & $\begin{array}{l}\text { Foliated biotite } \\
\text { granite }\end{array}$ & Gottlieb and Amato, 2008 & $\begin{array}{l}\text { Sample location not given; Age analysis by } \\
\text { SHRIMP }\end{array}$ \\
\hline Zircon & 676 & 15 & Orthogneiss & Patrick and McClelland, 1995 & $\begin{array}{l}\text { Location approximated from figure } 2 \text { in Patrick and } \\
\text { McClelland, } 1995\end{array}$ \\
\hline Zircon & 669 & 5 & Orthogneiss & John Aleinikoff, written comm., 2005 & - \\
\hline Zircon & 100.1 & 0.1 & Monzogranite & Richard Friedman, written comm., 2009 & Age analysis by TIMS \\
\hline Zircon & 107.8 & 0.2 & Granite & Richard Friedman, written comm., 2009 & Age analysis by TIMS \\
\hline
\end{tabular}




\section{Appendix}

\section{Conodont Data from the Seward Peninsula}

\author{
By Julie A. Dumoulin, Anita G. Harris, and \\ John E. Repetski
}

\section{Introduction}

Numerous conodont collections were made, mainly during the 1980's, to support geologic mapping on the Seward Peninsula. In this section we present table A-1, which lists virtually all conodont collections from this area that were examined by paleontologists of the U.S. Geological Survey as well as a few additional collections from unpublished industry reports. The table provides the location, age, geologic unit, and thermal level of these collections, as well as the sample collector and identifier (ID) and some explanatory remarks.

\section{Sources of Data}

Table A-1 contains 194 entries encompassing 234 collections. Most entries consist of a single collection, but some include two or more collections from the same location (typically, a measured section) that have identical ages and thermal levels. Fewer than half of the entries in this table have been previously published. Citations for published collections, mostly from the Bendeleben and Solomon quadrangles, are given in the remarks column. Cited references generally present faunal lists for the collections they include and may also contain more detailed age and (or) biofacies information than is given here. Transcriptions of original fossil reports (including faunal lists) for about half of the collections in table A-1 can be found online in the Alaska Paleontological Database at http://www. alaskafossil.org. The remarks column in table A-1 contains a note for all samples that were found in this database as of 09/10/07; the database is not yet complete, however, and more collections from the Seward Peninsula may be added later.

Conodont data are organized by quadrangle, listed from northwest (Teller) to southeast (Norton Bay). Sample locations are based on latitudes and longitudes supplied by the collector. Most samples were collected prior to common usage of GPS units by field geologists; thus, accuracies of these locations cannot be quantified. Most locations were verified using original field maps and (or) notes of the geologists who collected them. In some cases, latitudes and longitudes from the original database and (or) published references were corrected to reflect locations documented on the field maps.

The collectors' original field numbers are given for all samples. Some collections, mainly those that are relatively age-diagnostic, also have a U.S. Geological Survey collection number; this is the number under which fossil collections are generally filed in the U.S. Geological Survey repository. An Examination and Report (E\&R) shipment number is provided for most samples; for the samples listed in this appendix, this is the identifying number of the unpublished U.S. Geological Survey report in which the collection was first described. The E\&R number includes the year in which the report was written; for example, E\&R No. A-85-23B was written in 1985. It is important to note that the composition and age of most collections listed herein have not been reevaluated since they were originally analyzed; all samples that have been reexamined more recently are identified in the remarks column. Many E\&R reports can be found in the Alaska Geology technical archives unit in the Alaska Science Center, Anchorage, Alaska.

U.S. Geological Survey geologists collected most of the samples listed in this table, but students or employees of academia or industry submitted half of the samples from the Teller quadrangle. Anita G. Harris (formerly Epstein) and John E. Repetski identified the majority of the collections, but Timothy R. Carr, then with Atlantic Richfield Company, identified several collections submitted by geologists from the Anaconda Minerals Company. We thank Dr. Carr and Travis Hudson for allowing us to include these previously unpublished data in our table.

The data table contains two fields for geologic unit represented by the collection, headed "Geologic unit (this map)" and "Geologic unit (source map)." Unit designation in the current map is given for all samples. Where this name appears in brackets, it indicates an outcrop of the unit in question is too small to show at the scale of the current map. The source map unit is taken from the cited reference for previously published faunas, or was provided by the collector for unpublished collections.

Color changes in conodonts reflect the thermal history of the rocks that contain them (Epstein and others, 1977). Harris, Repetski, and their co-workers determined the conodont color alteration index (CAI) for almost all the collections in the database. Temperature ranges for CAIs were established from plots of experimental data by Epstein and others (1977) and Rejebian and others (1987); a CAI of 1 indicates a temperature range of less than $50-80^{\circ} \mathrm{C}$, whereas a CAI of 6 indicates temperatures in excess of $360{ }^{\circ} \mathrm{C}$ (table A-2). CAI can be equated to burial depths for a given geothermal gradient; for example, in the Appalachian basin, overburdens of $3,600-5,500$ $\mathrm{m}$ produced a CAI of 3 (Harris and others, 1978). Although there is a general correspondence between CAI and metamorphic history, CAI can be affected by multiple factors, some of which are not related to metamorphism. Some implications of CAIs of conodonts from the Seward Peninsula are discussed briefly below.

All samples listed herein were processed in order to obtain conodonts. In a few cases, the samples produced no conodonts but did yield other phosphatized or phosphatic fossils (such as lapworthellids) that provide age information. Such samples are noted in the remarks column.

Most collections in the database are stored at the U.S. Geological Survey in Reston, Virginia. However, faunas collected by geologists of Amoco Oil Corporation (a single sample in the Seward Peninsula database) are not part of the USGS collection but were examined by Anita Harris at the Amoco offices in Oklahoma during the 1980's. Harris determined the age and CAI of the collections; Amoco provided sample locations. 


\section{Geologic Implications}

Conodont data constrain the geologic, biogeographic, and thermal histories of the Seward Peninsula. A full discussion of these topics is beyond the scope of this text, but we highlight here some implications of the conodont collections, particularly those previously unpublished and (or) used to define the ages and affinities of the geologic units in the accompanying map.

\section{Nome Complex and Kugruk Fault Zone}

Most of the conodont data from the Nome Complex and Kugruk Fault Zone included here have been previously published and interpreted (Dumoulin and Till, 1985; Till and others, 1986; Till and Dumoulin, 1994; Harris and others, 1995; Dumoulin and others, 2002); highlights of these findings are summarized here. Conodonts constrain the age, biofacies, and thermal level of parts of the Nome Complex and of carbonate clasts in the conglomerate of unit TKs in the Kugruk Fault Zone.

Dolostones of the Nome Complex produced many more identifiable conodonts than did calcitic marbles and metalimestones (Till and others, 1986). This situation, which is the opposite of that found in unmetamorphosed carbonate rocks, introduced an unavoidable bias into our conodont collections. Conodont faunas from relatively pure carbonate strata that formed in shallow to very shallow water settings and were likely dolomitized during early diagenesis are over-represented in our database relative to their areal distribution within the Nome Complex. Nevertheless, conodonts have been obtained from a variety of lithofacies in the Nome Complex that formed in both shallow- and deep-water settings.

Shallow-water carbonate rocks of Cambrian through Devonian age, included in the Nome Complex by Till and others (1986), form small, discontinuous outcrops that are widely distributed across the central and eastern Seward Peninsula (units $€ d$, Od, Sd, and Ddm). Conodonts from these units (table A-1) provide biofacies data that strengthen depositional interpretations based on sparse sedimentary features, as well as precise age determinations that allow detailed correlations with lower Paleozoic strata of the York terrane and the Central belt of the Brooks Range (Till and others, 2008b). Conodont faunas from units $\mathrm{Od}$ and $\mathrm{Sd}$ correlate especially well with faunas from York terrane units Oal, OI, OEI, SOdl, and DSI.

Deeper-water carbonate rocks of early Paleozoic age, also included in the Nome Complex (Till and others, 1986), crop out in the northeastern and southeastern parts of the Seward Peninsula (units DObm and DEbm, respectively). Conodonts constrain the ages of these two units (table A-1), and indicate that Silurian carbonate turbidites are a significant component of both.

Conodonts provide some age constraints for parts of the Nome Complex dominated by non-carbonate lithologies, although carbonate layers in these rocks are mainly impure calcitic marbles that yielded few fossils (see table 3 in Appendix B of Till and others, 1986). Unit Oim produced a single conodont assemblage of Early-Middle Ordovician age, and unit DOx produced several collections of early Paleozoic age (table A-1). An enigmatic single conodont of probable Triassic age from marble in the Nome quadrangle (table A-1; Till and others, 2006) may indicate the presence of a fault-bounded upper Paleozoic sequence within unit Dcs.

Conodont data also illuminate the thermal history of the Seward Peninsula. Conodont CAIs from the Nome Complex are mainly 5-6 (dominantly 5-5.5) and indicate that the rocks containing these conodonts reached temperatures of $300-360{ }^{\circ} \mathrm{C}$ or greater (tables A-1, A-2; sh. 2; Rejebian and others, 1987). Temperature estimates for CAIs are derived from an Arrhenius plot of experimental data (table A-2; Epstein and others, 1977; Rejebian and others, 1987); each CAI value denotes a range of temperatures. For a given CAI value (for example, 5), the lower temperature $\left(300^{\circ} \mathrm{C}\right)$ represents a longer heating duration $(500$ million years) and the higher temperature $\left(480^{\circ} \mathrm{C}\right)$ corresponds to a shorter heating time (1 million years). Peak temperatures experienced by conodont-bearing rocks of the Nome Complex were likely closer to the high end of the CAI thermal range, because these temperatures were produced by blueschist and (or) greenschist metamorphic events that were, geologically speaking, relatively short-lived. This interpretation is supported by calcite-dolomite thermometry of Nome Complex samples, which indicates temperatures of $425-480{ }^{\circ} \mathrm{C}$ (Patrick and others, 1985).

Twenty percent of Nome Complex conodont assemblages include specimens with CAIs as high as 6.5, 7, and 8. These higher values generally occur in collections that contain a range of CAIs, and are commonest in units Od and, most notably, DObm, where values greater than or equal to 7 occur in almost two thirds of the collections. Saline and (or) corrosive fluids involved in episodes of dolomitization or mineralization can produce anomalously high CAIs (Till and others, 1986; Rejebian and others, 1987). Textural studies of conodonts with high CAIs and the rocks that contain them suggest that most of the highest CAIs in the Nome Complex reflect hydrothermal alteration related to dolomitization and (or) faulting.

Numerous conodonts obtained from conglomerate clasts in unit TKs in the Kugruk Fault Zone suggest that these cobbles were derived largely from carbonate rocks of the Nome Complex. Age, biofacies, and thermal level of the carbonate clasts correlate particularly well with those of units $\mathrm{Sd}$ and $\mathrm{Ddm}$. The abundance of carbonate clasts in unit TKs conglomerate that contain conodonts of Silurian age and shallow-water biofacies implies that such rocks once were more widely distributed on the Seward Peninsula.

\section{York Terrane and Grantley Harbor Fault Zone}

Most conodont data from the York terrane and Grantley Harbor Fault Zone included here have not been previously published, although preliminary summaries of some of these data are found in Dumoulin and Harris (1994), Till and Dumoulin (1994), Harris and others (1995), and Dumoulin and others (2002). Ordovician and Silurian strata of the York terrane previously were relatively well dated by megafossils (for example, Sainsbury 1969a, 1969b, 1972 and references therein), but conodonts provide tighter ages for much of this stratigraphy, particularly Early Ordovician rocks that contain few megafossils (units $\mathrm{Oal}, \mathrm{Ol}$ ). Conodonts also indicate that several units 
considered Precambrian by Sainsbury (1972) are at least partly of Ordovician age (such as rocks included in units OPI and OPt of this map). Questions that might profitably be addressed in the future using detailed conodont sampling include the age range and geographic distribution of Ordovician strata within composite units such as OPI and OPt, and the amount of age overlap between units Oal and OI.

Most rock units in the Grantley Harbor Fault Zone that were sampled for conodonts were barren. However, unit Pzp produced a few fragmentary conodonts that indicate an Ordovician-Triassic age (table A-1; T. Carr and T. Hudson, written commun., 1982, 1984).

Conodonts contribute greatly to our understanding of the paleobiogeography of the York terrane. Conodont assemblages from several units, most notably $\mathrm{Ol}$ and SOdl, include both Siberian and Laurentian (North American) endemic forms, a pattern that is also seen in megafaunas from these rocks (Dumoulin and Harris, 1994; Blodgett and others, 2002; Dumoulin and others, 2002). Similar mixed biogeographic affinities characterize conodonts in unit Od of the Nome Complex, the Baird Group and related rocks in the Central belt of the Brooks Range, and lower Paleozoic strata of the Farewell terrane in interior Alaska. These faunal correlations, along with detailed lithofacies matches between coeval strata in these successions, suggest that lower Paleozoic rocks on Seward Peninsula, in the Brooks Range, and in the Farewell terrane may once have been part of a single continental fragment situated between Siberia and Laurentia (Dumoulin and others, 2002).

Conodont CAIs from the York terrane generally are lower than those from the Nome Complex and define three thermal provinces (table A-1; sh. 2). The first province consists of outcrops of units $\mathrm{Oal}, \mathrm{Ol}$, and Ols between lat 65'23.9' and $65^{\circ} 33^{\prime}$ N. and long $167^{\circ} 14^{\prime}$ and $167^{\circ} 23^{\prime}$ W. (Teller B-5 and C-5 quadrangles) that have CAIs mainly of $2-2.5$. These values indicate temperatures of $60-150^{\circ} \mathrm{C}$ (table $\left.\mathrm{A}-2\right)$ and demonstrate that these York terrane rocks are still within the oil window; a CAI of 3, denoting temperatures of $120-190^{\circ} \mathrm{C}$, approximates the thermal limit of oil preservation (Bird and others, 1999). The second province contains rocks with slightly higher CAIs (3-3.5); these rocks are located in the Don River area (Teller B-4 quadrangle), and consist mainly of unit SOdl. CAIs elsewhere in the York terrane are mostly 4-4.5 and delineate a third province; these values are found in units Oal, Ol, and Ols where they occur outside of the first province, as well as unit DSI and much of unit OPI.

Higher CAIs of 5-6, equivalent to those found in the Nome Complex, occur in a few conodont assemblages from the York terrane (table A-1). Some higher values likely reflect contact metamorphic effects associated with intrusion of Cretaceous dikes and plutons (for example, a few outcrops of units Oal and $\mathrm{Ol}$ in the Teller B-5 and C-5 quadrangles; Toro and others, written commun., 2006). Other high CAIs occur near the western edge of the York terrane (unit SOul in the Teller C-2 quadrangle). Lastly, CAIs greater than or equal to 5 characterize all three conodont assemblages obtained from unit OPt and several assemblages from unit $\mathrm{OPI}$. Recrystallization and schistose to semi-schistose fabrics characterize most of unit OPt and parts of unit OPI; these rocks may be part of a more deformed and (or) mildly metamorphosed structural plate that underlies parts of the York terrane (Toro and others, 2006).

As outlined above, CAIs from the York terrane are not simply correlated with unit age - that is, older rocks do not have consistently higher CAIs than younger rocks. Thus, these CAIs were most likely not produced by simple burial metamorphism. Instead, York terrane thermal data may reflect tectonic burial by thrust sheets, as has been proposed to explain CAI patterns in the western Brooks Range (Harris and others, 1987). Additional conodont sampling, in concert with detailed structural studies, could help define the composition and extent of discrete thrust sheets within the York terrane. 
Table A-1. Conodont data from the Seward Peninsula. (table spans facing page)

[Ages listed have not been revised to reflect all changes in stratigraphic terminology that have occurred since the ages given here were Ordovician conodont zonation, Series, and Stage usage herein follows that given in Harris and others (1995). Geologic unit (source map) from cited to map units of Till and others (1986). For Teller quadrangle, source map units refer to map units of Sainsbury (1972) if unspecified; (69b) indicates a column. Alaska Paleontological Database found online at http://www.alaskafossil.org. E\&R, Examination and Report by USGS paleontologist; on sheet 2; see table A-2 for temperature ranges for CAI values]

\begin{tabular}{|c|c|c|c|c|c|c|c|c|}
\hline \multirow[b]{2}{*}{ Field no. } & \multirow[b]{2}{*}{ Quadrangle } & \multicolumn{2}{|c|}{ Lat (N) } & \multicolumn{2}{|c|}{ Long (W) } & \multirow[b]{2}{*}{ Age } & \multicolumn{2}{|c|}{ Geologic unit } \\
\hline & & Deg & Min & Deg & Min & & (This map) & $\begin{array}{l}\text { (Source } \\
\text { map) }\end{array}$ \\
\hline AS-001 & Teller A-3 & 65 & 14.37 & 166 & 18.54 & Ordovician-Triassic & Pzp & p€s \\
\hline AS-031 & Teller B-2 & 65 & 19.96 & 165 & 47.57 & early Paleozoic & DOx & p€nl \\
\hline 07AD11A & Teller B-3 & 65 & 21.49 & 166 & 24.72 & middle Early Ordovician ("Low Diversity Interval") & OPI & $\mathrm{p} \in \mathrm{l}$ \\
\hline AS-004 through -007 & Teller B-3 & 65 & 22.45 & 166 & 27.54 & Early-early Middle Ordovician & OPI & $\mathrm{p} \in \mathrm{l}$ \\
\hline $85 \mathrm{AKn} 12$ & Teller B-4 & 65 & 24 & 166 & 35.8 & $\begin{array}{l}\text { latest Early Ordovician-earliest Middle Ordovician } \\
\text { (Reutterodus andinus Zone to Tripodus laevis Zone) }\end{array}$ & Ol & Ol \\
\hline $6-30-85 \mathrm{D}, \mathrm{C}$ & Teller B-4 & 65 & 25.9 & 166 & 34.2 & $\begin{array}{l}\text { middle Early Ordovician (Macerodus dianae Zone } \\
\text { to Acodus deltatus-Oneotodus costatus Zone) }\end{array}$ & Ol & Ol \\
\hline $7-21-84 \mathrm{C}-\mathrm{F}$ & Teller B-4 & 65 & 29.68 & 166 & 55.34 & Late Ordovician & SOdl & sOdl \\
\hline $7-21-84 \mathrm{G}$ & Teller B-4 & 65 & 29.68 & 166 & 55.34 & Late Ordovician & SOdl & SOdl \\
\hline $7-21-84 \mathrm{H}$ & Teller B-4 & 65 & 29.68 & 166 & 55.34 & $\begin{array}{l}\text { latest Ordovician (Gamachian)-early Silurian (age } \\
\text { constrained by overlying samples) }\end{array}$ & SOdl & SOdl \\
\hline 7-21-84I-K & Teller B-4 & 65 & 29.68 & 166 & 55.34 & Very probably early Silurian & SOdl & SOdl or SI \\
\hline $7-22-84 A$ & Teller B-4 & 65 & 29.68 & 166 & 55.34 & early Silurian (earliest Llandovery-Llandovery C5) & SOdl & SOdl or SI \\
\hline 7-22-84B, C, E, F & Teller B-4 & 65 & 29.91 & 166 & 55.75 & early late Silurian (Ludlow) & SOdl & SI \\
\hline $7-22-84 \mathrm{G}$ & Teller B-4 & 65 & 29.91 & 166 & 55.75 & early late Silurian (Ludlow, probably early Ludlow) & SOdl & SI \\
\hline 7-22-84H-J & Teller B-4 & 65 & 29.91 & 166 & 55.75 & early late Silurian (Ludlow)-Middle Devonian & SOdl & SI \\
\hline 68ADu27 & Teller B-4 & 65 & 29.8 & 166 & 56 & $\begin{array}{l}\text { middle-early late Silurian (latest Wenlock-early } \\
\text { Ludlow) }\end{array}$ & SOdl & SI \\
\hline 68ADu19, 25 & Teller B-4 & 65 & 29.8 & 166 & 56 & $\begin{array}{l}\text { middle Silurian (late Wenlock); age constrained by } \\
\text { co-occurring and (or) overlying megafossils }\end{array}$ & SOdl & SI \\
\hline 68ADu18 & Teller B-4 & 65 & 29.8 & 166 & 56 & $\begin{array}{l}\text { Late Ordovician; age constrained by underlying } \\
\text { samples }\end{array}$ & SOdl & SOdl \\
\hline $7-21-84 \mathrm{~A}$ & Teller B-4 & 65 & 29.85 & 166 & 55.88 & early Silurian & SOdl & SI \\
\hline $7-21-84 \mathrm{~B}$ & Teller B-4 & 65 & 29.85 & 166 & 55.88 & probably early Silurian & SOdl & SI \\
\hline 03JT25 & Teller B-5 & 65 & 23.9 & 167 & 16.75 & $\begin{array}{l}\text { middle Early Ordovician (Macerodus dianae or } A \text {. } \\
\text { deltatus-O. costatus Zone) }\end{array}$ & Oal & Oal \\
\hline 7-23-84A-H, K & Teller B-5 & 65 & 24.5 & 167 & 17.6 & $\begin{array}{l}\text { middle Early Ordovician ("Low Diversity Interval" } \\
\text { to Macerodus dianae Zone) }\end{array}$ & Oal & Oal \\
\hline $7-3-85 I$ & Teller B-5 & 65 & 24.3 & 167 & 0.8 & $\begin{array}{l}\text { Early Ordovician (Rossodus manitouensis Zone to } \\
\text { Macerodus dianae Zone) }\end{array}$ & $\mathrm{Ol}$ & Ol \\
\hline 03JT26 & Teller B-5 & 65 & 24.74 & 167 & 16.7 & $\begin{array}{l}\text { Early (but not earliest) Ordovician; Rossodus mani- } \\
\text { touensis Zone or younger }\end{array}$ & Oal & Oal \\
\hline
\end{tabular}


determined. For example, the Middle/UpperOrdovician boundary has been revised downward considerably(see, for example, Webbyand others, 2004). reference (if published) or provided by collector. For Bendeleben, Candle, Kotzebue, Norton Bay, and Solomon quadrangles, source map units refer map unit of Sainsbury (1969b). Unit in bracket (for example, [Ols]) indicates outcrop too small to show on map, or other issue explained in remarks ID, conodont fauna identifier; N.D., not determined; USGS no., number under which collection is filed in USGS repository. Localities are plotted

\begin{tabular}{|c|c|c|c|c|c|c|}
\hline \multicolumn{2}{|c|}{$\begin{array}{l}\text { Color } \\
\text { Alteration } \\
\text { Index (CAI) }\end{array}$} & \multirow[b]{2}{*}{ USGS no. } & \multirow[b]{2}{*}{$\begin{array}{c}\text { E\&R } \\
\text { shipment no. }\end{array}$} & \multirow[b]{2}{*}{$\begin{array}{l}\text { Sample } \\
\text { collector }\end{array}$} & \multirow[b]{2}{*}{$\begin{array}{c}\text { Sample } \\
\text { ID }\end{array}$} & \multirow[b]{2}{*}{ Remarks } \\
\hline Min & Max & & & & & \\
\hline 5 & 5 & - & - & Anaconda & Carr & $\begin{array}{l}\text { Sample collected by Anaconda Minerals Co. from graphitic shale; location } \\
\text { approximate. Conodonts identified by T. Carr, Atlantic Richfield Co., 1982, } 1984 .\end{array}$ \\
\hline 7 & 7 & - & - & Anaconda & Carr & $\begin{array}{l}\text { Sample collected by Anaconda Minerals Co.; location approximate. Conodonts } \\
\text { identified by T. Carr, Atlantic Richfield Co., 1982, } 1984 .\end{array}$ \\
\hline $4-4.5$ & 4.5 & 12111-CO & - & Dumoulin & Harris, Repetski & Sample re-examined by J.E. Repetski, 8/10. \\
\hline 5 & 5 & - & - & Anaconda & Carr & $\begin{array}{l}\text { Samples (4) collected by Anaconda Minerals Co.; location approximate. } \\
\text { Conodonts identified by T. Carr, Atlantic Richfield Co., 1982, } 1984 .\end{array}$ \\
\hline 3.5 & 4 & 10018-CO & A- $85-23 A$ & Kaufman & Harris & Entry in Alaska Paleontological Database. \\
\hline 4 & 4 & $\begin{array}{l}10215-\mathrm{CO} \\
10216-\mathrm{CO}\end{array}$ & A- $85-23 F$ & Harris & Harris, Repetski & $\begin{array}{l}\text { Samples re-examined by J.E. Repetski, 2/08. Entries in Alaska Paleontological } \\
\text { Database. }\end{array}$ \\
\hline 3.5 & 3.5 & $\begin{array}{l}10241-\mathrm{CO} \\
\text { through } \\
10244-\mathrm{CO}\end{array}$ & A- $85-23 \mathrm{H}$ & Harris & Harris & $\begin{array}{l}\text { Age revised by A.G. Harris in } 1995 \text {. Entries in Alaska Paleontological Database. } \\
\text { All } 4 \text { samples are from measured section } 84 \text { ADn118 near the Don River. Section } \\
\text { started at lat/long given here, and ended at lat/long given for samples 7-22-84B } \\
\text { through J. Precise locations were not determined for each sample. }\end{array}$ \\
\hline 3 & 3 & $10245-\mathrm{CO}$ & A- $85-23 \mathrm{H}$ & Harris & Harris & $\begin{array}{l}\text { Age revised by A.G. Harris in 1995. Entry in Alaska Paleontological Database. } \\
\text { Sample from measured section 84ADn118 near the Don River. }\end{array}$ \\
\hline 3 & 3 & - & A- $85-23 \mathrm{H}$ & Harris & Harris & $\begin{array}{l}\text { Entry in Alaska Paleontological Database. Sample from measured section } \\
\text { 84ADn118 near the Don River. }\end{array}$ \\
\hline 3 & 3 & $\begin{array}{l}11242-S D \\
\text { through } \\
11244-S D\end{array}$ & A- $85-23 \mathrm{H}$ & Harris & Harris & $\begin{array}{l}\text { Entries in Alaska Paleontological Database. All } 3 \text { samples from measured section } \\
\text { 84ADn118 near the Don River. }\end{array}$ \\
\hline 3 & 3 & $11245-\mathrm{SD}$ & A- $85-23 \mathrm{H}$ & Harris & Harris & $\begin{array}{l}\text { Entry in Alaska Paleontological Database. Sample from measured section } \\
\text { 84ADn118 near the Don River. }\end{array}$ \\
\hline 3 & 3 & $\begin{array}{l}\text { 11246-SD } \\
\text { through } \\
11249-\mathrm{SD}\end{array}$ & A- $85-23 \mathrm{H}$ & Harris & Harris & $\begin{array}{l}\text { Entries in Alaska Paleontological Database. All } 4 \text { samples from measured section } \\
\text { 84ADn118 near the Don River. }\end{array}$ \\
\hline 3 & 3 & $11250-\mathrm{SD}$ & A- $85-23 \mathrm{H}$ & Harris & Harris & $\begin{array}{l}\text { Entry in Alaska Paleontological Database. Sample from measured section } \\
\text { 84ADn118 near the Don River. }\end{array}$ \\
\hline 3 & 3 & $\begin{array}{l}\text { 11251-SD } \\
\text { through } \\
11253-\mathrm{SD}\end{array}$ & A- $85-23 \mathrm{H}$ & Harris & Harris & $\begin{array}{l}\text { Entries in Alaska Paleontological Database. All } 3 \text { samples from measured section } \\
\text { 84ADn118 near the Don River. }\end{array}$ \\
\hline 3 & 3 & 8345-SD & A-84-14 & Dutro & Harris & $\begin{array}{l}\text { Entry in Alaska Paleontological Database. From measured section near the Don } \\
\text { River. }\end{array}$ \\
\hline 3 & 3 & $\begin{array}{l}\text { 8337-SD, } \\
8343-\mathrm{SD}\end{array}$ & A-84-14 & Dutro & Harris & $\begin{array}{l}\text { Entries in Alaska Paleontological Database. From measured section near the Don } \\
\text { River. }\end{array}$ \\
\hline 3 & 3 & D2036-CO & A-84-14 & Dutro & Harris & $\begin{array}{l}\text { Entry in Alaska Paleontological Database. From measured section near the Don } \\
\text { River. }\end{array}$ \\
\hline 3 & 3 & 11254-SD & A- $85-23 \mathrm{H}$ & Harris & Harris & Entry in Alaska Paleontological Database. \\
\hline 3 & 3 & $11255-\mathrm{SD}$ & A- $85-23 \mathrm{H}$ & Harris & Harris & Entry in Alaska Paleontological Database. \\
\hline 2.5 & 2.5 & 11971-CO & - & Toro & Repetski & Sample from massive micritic limestone. \\
\hline 4 & 4 & $\begin{array}{l}\text { 10231-CO } \\
\text { through } \\
10239-\mathrm{CO}\end{array}$ & A-85-23G & Harris & Repetski & $\begin{array}{l}\text { Samples re-examined by J.E. Repetski, 2/08. Entries in Alaska Paleontological } \\
\text { Database. All } 9 \text { samples are from a measured section along Koteebue Creek. }\end{array}$ \\
\hline 4 & 4 & 10230-SD & A- $85-23 \mathrm{~F}$ & Harris & Harris, Repetski & $\begin{array}{l}\text { Sample re-examined by J.E. Repetski, 2/08. Entry in Alaska Paleontological } \\
\text { Database. }\end{array}$ \\
\hline 2.5 & 3 & $11972-\mathrm{CO}$ & - & Toro & Repetski & Sample from brown-gray, massive, medium-bedded micritic liimestone. \\
\hline
\end{tabular}


Table A-1. Conodont data from the Seward Peninsula._Continued (table spans facing page)

[Ages listed have not been revised to reflect all changes in stratigraphic terminology that have occurred since the ages given here were Ordovician conodont zonation, Series, and Stage usage herein follows that given in Harris and others (1995). Geologic unit (source map) from cited to map units of Till and others (1986). For Teller quadrangle, source map units refer to map units of Sainsbury (1972) if unspecified; (69b) indicates a column. Alaska Paleontological Database found online at http://www.alaskafossil.org. E\&R, Examination and Report by USGS paleontologist; on sheet 2; see table A-2 for temperature ranges for CAl values]

\begin{tabular}{|c|c|c|c|c|c|c|c|c|}
\hline \multirow[b]{2}{*}{ Field no. } & \multirow[b]{2}{*}{ Quadrangle } & \multicolumn{2}{|c|}{ Lat (N) } & \multicolumn{2}{|c|}{ Long (W) } & \multirow[b]{2}{*}{ Age } & \multicolumn{2}{|c|}{ Geologic unit } \\
\hline & & Deg & Min & Deg & Min & & (This map) & $\begin{array}{l}\text { (Source } \\
\text { map) }\end{array}$ \\
\hline 7-3-85D-G, C-A & Teller B-5 & 65 & 25.1 & 167 & 1.5 & $\begin{array}{l}\text { middle Early Ordovician ("Low Diversity Interval" } \\
\text { to Macerodus dianae Zone) }\end{array}$ & Ol & Ol \\
\hline 03JT27 & Teller B-5 & 65 & 25.24 & 167 & 16.42 & $\begin{array}{l}\text { middle Early Ordovician (Macerodus dianae or } A \text {. } \\
\text { deltatus-O. costatus Zone) }\end{array}$ & Oal & Oal \\
\hline 03JT28 & Teller B-5 & 65 & 25.37 & 167 & 17.24 & $\begin{array}{l}\text { middle Early Ordovician (Macerodus dianae or } A \text {. } \\
\text { deltatus-O. costatus Zone) }\end{array}$ & Ol & Ol \\
\hline 02JT14 & Teller B-5 & 65 & 26.84 & 167 & 18.97 & $\begin{array}{l}\text { middle Early Ordovician (Macerodus dianae or } A \text {. } \\
\text { deltatus-O. costatus Zone) }\end{array}$ & Ol & Ol \\
\hline 02JT13 & Teller B-5 & 65 & 26.92 & 167 & 19.41 & middle Early Ordovician (Macerodus dianae Zone) & Ol & Ol \\
\hline 02JT16 & Teller B-5 & 65 & 27.03 & 167 & 18.15 & probably Ordovician & Oal & Oal \\
\hline 02JT12 & Teller B-5 & 65 & 27.09 & 167 & 19.77 & $\begin{array}{l}\text { Early Ordovician (most likely Macerodus dianae } \\
\text { Zone or younger Ibexian) }\end{array}$ & Ol & Ol \\
\hline 02JT11 & Teller B-5 & 65 & 27.24 & 167 & 20.03 & $\begin{array}{l}\text { middle Early Ordovician (Acodus deltatus-Oneoto- } \\
\text { dus costatus Zone) }\end{array}$ & Ol & Ol \\
\hline 02JT17 & Teller B-5 & 65 & 27.39 & 167 & 18.31 & $\begin{array}{l}\text { early Early Ordovician (Rossodus manitouensis } \\
\text { Zone) }\end{array}$ & Oal & Oal \\
\hline 03JT06 & Teller B-5 & 65 & 29.29 & 167 & 16.01 & $\begin{array}{l}\text { Early Ordovician; most likely } M . \text { dianae or } A \text {. } \\
\text { deltatus-O. costatus Zone. }\end{array}$ & Oal & Oal \\
\hline $7-1-85 \mathrm{~J}, \mathrm{H}$ & Teller B-5 & 65 & 29.6 & 167 & 4.5 & $\begin{array}{l}\text { earliest Middle Ordovician (latest Arenig-early } \\
\text { Llanvirn) }\end{array}$ & Ols & $\begin{array}{l}\text { Oshl, Olsh } \\
\text { (69b) }\end{array}$ \\
\hline 03JT10 & Teller B-5 & 65 & 30 & 167 & 17.21 & $\begin{array}{l}\text { middle Early Ordovician (Macerodus dianae or } A \text {. } \\
\text { deltatus-O. costatus Zone) }\end{array}$ & Ol & Ol \\
\hline 85ATi116B & Teller B-6 & 65 & 28.2 & 167 & 36.8 & middle Early-Late Ordovician & OPt & p€s \\
\hline 85ADn24A & Teller C-1 & 65 & 32.3 & 165 & 20.6 & late Silurian-Early Devonian & $\begin{array}{l}\text { DOx (overlay } \\
\text { pattern) }\end{array}$ & DOx \\
\hline $85 \mathrm{ADn} 25 \mathrm{~A}$ & Teller C-1 & 65 & 33.1 & 165 & 23.64 & Silurian (late Llandovery-Ludlow) & $\begin{array}{l}\text { DOx (overlay } \\
\text { pattern) }\end{array}$ & DOx \\
\hline 85ADn20B & Teller C-1 & 65 & 39.9 & 165 & 29.7 & late Silurian-Devonian & $\begin{array}{l}\text { DOx (overlay } \\
\text { pattern) }\end{array}$ & DOx \\
\hline $7-8-85 \mathrm{~A}$ & Teller C-2 & 65 & 33 & 165 & 57.7 & $\begin{array}{l}\text { Silurian (probably late Llandovery-Wenlock); age } \\
\text { constrained by co-occurring corals }\end{array}$ & SOul & Oum \\
\hline 82AH105 & Teller C-2 & 65 & 36.62 & 165 & 53.86 & middle Early Ordovician & OPI & $\mathrm{p} € \mathrm{l}$ \\
\hline $7-20-84 \mathrm{~A}$ & Teller C-2 & 65 & 38.4 & 165 & 55.3 & $\begin{array}{l}\text { middle Early Ordovician (Rossodus manitouensis } \\
\text { Zone to "Low Diversity Interval") }\end{array}$ & OPI & $\mathrm{p} € \mathrm{l}$ \\
\hline AS-14 & Teller C-3 & 65 & 31.95 & 166 & 3.72 & Cambrian-Triassic & OPI & Op€l \\
\hline $7-20-84 \mathrm{C}$ & Teller C-3 & 65 & 33.2 & 166 & 8.3 & Early Ordovician (early to middle Arenig) & OPI & Op€l \\
\hline $7-8-85 \mathrm{C}$ & Teller C-3 & 65 & 33.8 & 166 & 19.5 & $\begin{array}{l}\text { early-middle Early Ordovician (Rossodus mani- } \\
\text { touensis Zone to Macerodus dianae Zone) }\end{array}$ & OPI & Op€l \\
\hline $7-20-84 B$ & Teller C-3 & 65 & 33.9 & 166 & 8.2 & Early-Middle Ordovician & OPI & Op€l \\
\hline 7-20-84E, F & Teller C-3 & 65 & 34.2 & 166 & 9.5 & $\begin{array}{l}\text { Silurian (Llandovery-middle Wenlock); age con- } \\
\text { strained by adjacent collections }\end{array}$ & DSI & DI \\
\hline
\end{tabular}


determined. For example, the Middle/UpperOrdovician boundary has been revised downward considerably(see, for example, Webby and others, 2004). reference (if published) or provided by collector. For Bendeleben, Candle, Kotzebue, Norton Bay, and Solomon quadrangles, source map units refer map unit of Sainsbury (1969b). Unit in bracket (for example, [Ols]) indicates outcrop too small to show on map, or other issue explained in remarks ID, conodont fauna identifier; N.D., not determined; USGS no., number under which collection is filed in USGS repository. Localities are plotted

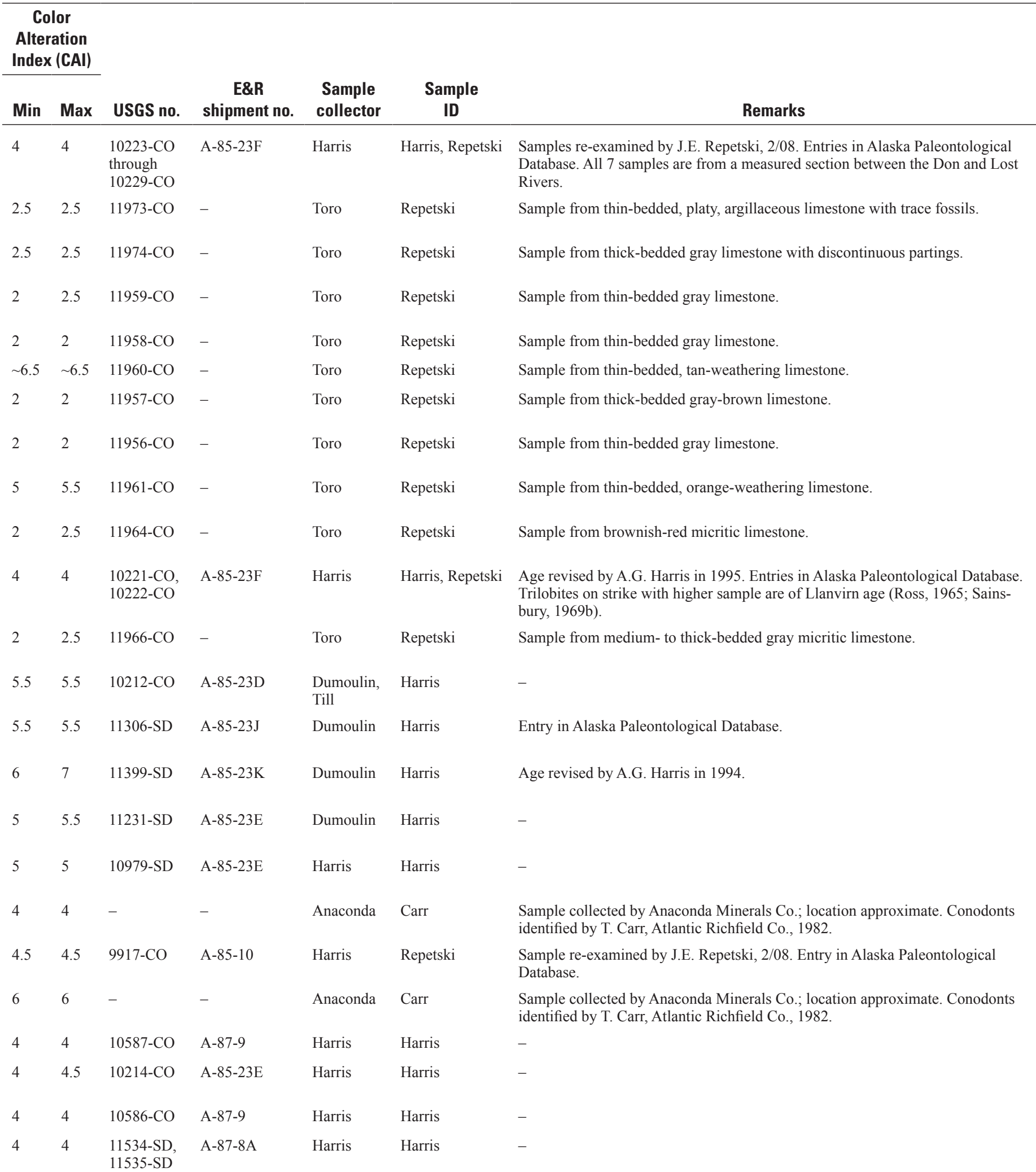


Table A-1. Conodont data from the Seward Peninsula._Continued (table spans facing page)

[Ages listed have not been revised to reflect all changes in stratigraphic terminology that have occurred since the ages given here were Ordovician conodont zonation, Series, and Stage usage herein follows that given in Harris and others (1995). Geologic unit (source map) from cited to map units of Till and others (1986). For Teller quadrangle, source map units refer to map units of Sainsbury (1972) if unspecified; (69b) indicates a column. Alaska Paleontological Database found online at http://www.alaskafossil.org. E\&R, Examination and Report by USGS paleontologist; on sheet 2; see table A-2 for temperature ranges for CAl values]

\begin{tabular}{|c|c|c|c|c|c|c|c|c|}
\hline \multirow[b]{2}{*}{ Field no. } & \multirow[b]{2}{*}{ Quadrangle } & \multicolumn{2}{|c|}{ Lat (N) } & \multicolumn{2}{|c|}{ Long (W) } & \multirow[b]{2}{*}{ Age } & \multicolumn{2}{|c|}{ Geologic unit } \\
\hline & & Deg & Min & Deg & Min & & (This map) & $\begin{array}{l}\text { (Source } \\
\text { map) }\end{array}$ \\
\hline 7-20-84G, H & Teller C-3 & 65 & 34.4 & 166 & 9.2 & $\begin{array}{l}\text { Silurian (Llandovery-middle Wenlock); age con- } \\
\text { strained by adjacent collections }\end{array}$ & DSI & DI \\
\hline $7-20-84 I$ & Teller C-3 & 65 & 34.4 & 166 & 9.2 & middle Silurian (middle Wenlock) & DSI & $\mathrm{DI}$ \\
\hline 07AD9Z & Teller C-3 & 65 & 34.62 & 166 & 20.33 & middle Early Ordovician ("Low Diversity Interval") & $\mathrm{OPI}$ & Ol \\
\hline 07AD10A & Teller C-3 & 65 & 34.69 & 166 & 20.4 & middle Early Ordovician ("Low Diversity Interval") & $\mathrm{OBI}$ & Ol \\
\hline $7-22-84 \mathrm{~K}$ & Teller C-4 & 65 & 30.1 & 166 & 55.2 & Middle Ordovician-Silurian & Ol? & Ol? \\
\hline $7-22-84 \mathrm{~L}$ & Teller C-4 & 65 & 31.3 & 166 & 54.2 & Middle-Late Ordovician & Ol? & Ol? \\
\hline 03JT12 & Teller C-5 & 65 & 30.59 & 167 & 18.87 & Late Cambrian through early Paleozoic & OI & Ol \\
\hline $7-5-85 \mathrm{~A}$ & Teller C-5 & 65 & 30.6 & 167 & 20.1 & Middle Ordovician & Ols & $\begin{array}{l}\text { Oshl, Olsh } \\
(69 b)\end{array}$ \\
\hline $7-5-85 \mathrm{~B}, \mathrm{C}$ & Teller C-5 & 65 & 30.6 & 167 & 20.1 & middle Early-earliest Middle Ordovician & Ols & $\begin{array}{l}\text { Oshl, Olsh } \\
(69 b)\end{array}$ \\
\hline $7-5-85 \mathrm{D}, \mathrm{E}$ & Teller C-5 & 65 & 30.6 & 167 & 20.1 & earliest Middle Ordovician (latest Arenig) & Ols & Olsh \\
\hline 93BK44 & Teller C-5 & 65 & 30.67 & 167 & 19.79 & $\begin{array}{l}\text { late Early Ordovician (middle Arenig; lower Oe. } \\
\text { communis Zone) }\end{array}$ & Ol & $\begin{array}{l}\text { Ol (at/near } \\
\text { top of unit) }\end{array}$ \\
\hline 93BK46 & Teller C-5 & 65 & 30.7 & 167 & 20.59 & $\begin{array}{l}\text { late Early to early Middle Ordovician (middle-late } \\
\text { Arenig) }\end{array}$ & Ols & Olsh (69b) \\
\hline $7-5-85 \mathrm{H}$ & Teller C-5 & 65 & 30.75 & 167 & 22 & $\begin{array}{l}\text { middle Early Ordovician ("Low Diversity Interval" } \\
\text { to lower Macerodus dianae Zone) }\end{array}$ & OI & Ol \\
\hline $7-5-85 \mathrm{I}$ & Teller C-5 & 65 & 30.75 & 167 & 22 & $\begin{array}{l}\text { probably middle Early Ordovician (early middle } \\
\text { Arenig) }\end{array}$ & OI & Ol \\
\hline $7-5-85 \mathrm{~F}$ & Teller C-5 & 65 & 30.75 & 167 & 22 & middle Early Ordovician (early middle Arenig) & Ol & Ol \\
\hline 03JT11 & Teller C-5 & 65 & 30.78 & 167 & 18.48 & $\begin{array}{l}\text { middle Early Ordovician (Macerodus dianae or } A \text {. } \\
\text { deltatus-O. costatus Zone) }\end{array}$ & Ol & Ol \\
\hline 02JT33 & Teller C-5 & 65 & 30.87 & 167 & 14.61 & middle Early Ordovician (Macerodus dianae Zone) & Ol & Ol \\
\hline 93BK47 & Teller C-5 & 65 & 31.1 & 167 & 21.52 & middle Early Ordovician (Macerodus dianae Zone) & Oal & Oal \\
\hline 93BK8 & Teller C-5 & 65 & 31.05 & 167 & 19.2 & $\begin{array}{l}\text { middle Early Ordovician ("Low Diversity Interval" } \\
\text { to Macerodus dianae Zone) }\end{array}$ & Ol & Ol \\
\hline 03JT07 & Teller C-5 & 65 & 30.69 & 167 & 13.69 & probably Middle-Late Ordovician & [Ols] & Olsh (69b) \\
\hline 93BK39 & Teller C-5 & 65 & 31.53 & 167 & 22.57 & $\begin{array}{l}\text { middle Early Ordovician ("Low Diversity Interval" } \\
\text { to Macerodus dianae Zone) }\end{array}$ & Ol & Ol \\
\hline 93ВK9 & Teller C-5 & 65 & 31.7 & 167 & 19.09 & $\begin{array}{l}\text { middle Early Ordovician ("Low Diversity Interval" } \\
\text { to Macerodus dianae Zone) }\end{array}$ & OI & Ol \\
\hline 93BK10 & Teller C-5 & 65 & 31.7 & 167 & 18.71 & $\begin{array}{l}\text { middle Early Ordovician ("Low Diversity Interval" } \\
\text { to Macerodus dianae Zone) }\end{array}$ & OI & Ol \\
\hline 93BK22 & Teller C-5 & 65 & 31.7 & 167 & 19.13 & $\begin{array}{l}\text { middle Early Ordovician (Macerodus dianae Zone to } \\
\text { lowest Acodus deltatus-Oneotodus costatus Zone) }\end{array}$ & Ol & Ol \\
\hline
\end{tabular}


determined. For example, the Middle/UpperOrdovician boundary has been revised downward considerably(see, for example, Webbyand others, 2004). reference (if published) or provided by collector. For Bendeleben, Candle, Kotzebue, Norton Bay, and Solomon quadrangles, source map units refer map unit of Sainsbury (1969b). Unit in bracket (for example, [Ols]) indicates outcrop too small to show on map, or other issue explained in remarks ID, conodont fauna identifier; N.D., not determined; USGS no., number under which collection is filed in USGS repository. Localities are plotted

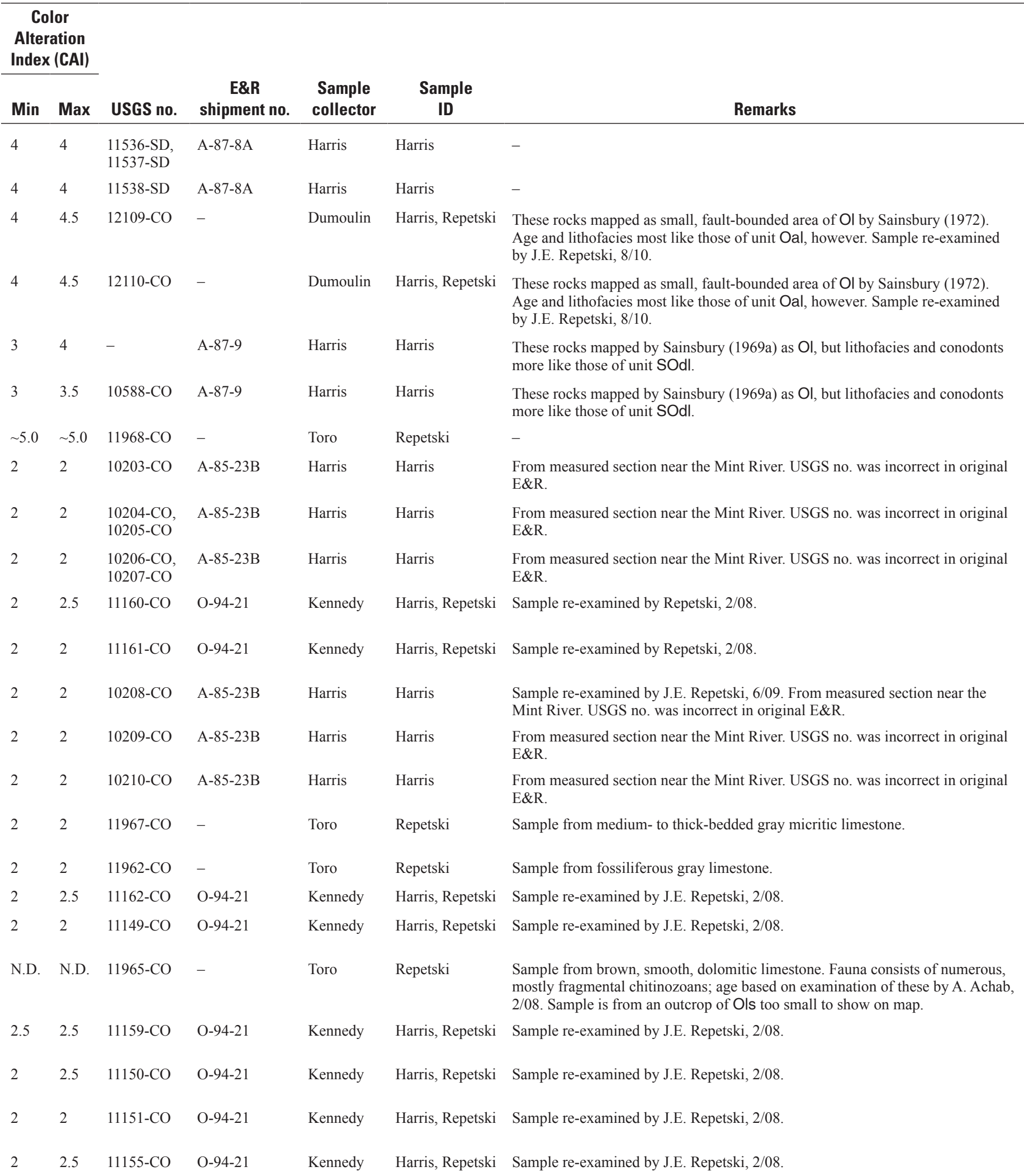


Table A-1. Conodont data from the Seward Peninsula._Continued (table spans facing page)

[Ages listed have not been revised to reflect all changes in stratigraphic terminology that have occurred since the ages given here were Ordovician conodont zonation, Series, and Stage usage herein follows that given in Harris and others (1995). Geologic unit (source map) from cited to map units of Till and others (1986). For Teller quadrangle, source map units refer to map units of Sainsbury (1972) if unspecified; (69b) indicates a column. Alaska Paleontological Database found online at http://www.alaskafossil.org. E\&R, Examination and Report by USGS paleontologist; on sheet 2; see table A-2 for temperature ranges for CAl values]

\begin{tabular}{|c|c|c|c|c|c|c|c|c|}
\hline \multirow[b]{2}{*}{ Field no. } & \multirow[b]{2}{*}{ Quadrangle } & \multicolumn{2}{|c|}{ Lat (N) } & \multicolumn{2}{|c|}{ Long (W) } & \multirow[b]{2}{*}{ Age } & \multicolumn{2}{|c|}{ Geologic unit } \\
\hline & & Deg & Min & Deg & Min & & (This map) & $\begin{array}{l}\text { (Source } \\
\text { map) }\end{array}$ \\
\hline $93 \mathrm{BK} 7$ & Teller C-5 & 65 & 31.78 & 167 & 18.96 & $\begin{array}{l}\text { middle Early Ordovician ("Low Diversity Interval" } \\
\text { to Macerodus dianae Zone) }\end{array}$ & Ol & Ol \\
\hline 93BK6 & Teller C-5 & 65 & 31.81 & 167 & 18.95 & $\begin{array}{l}\text { middle Early Ordovician ("Low Diversity Interval" } \\
\text { to Macerodus dianae Zone) }\end{array}$ & Ol & Ol \\
\hline 93BK33 & Teller C-5 & 65 & 31.88 & 167 & 19.75 & middle Late Cambrian-Triassic & ORI & $\begin{array}{l}\text { p€I, pOal } \\
(69 b)\end{array}$ \\
\hline 03JT22 & Teller C-5 & 65 & 32.03 & 167 & 22.42 & $\begin{array}{l}\text { Early Ordovician (probably Macerodus dianae or } A \text {. } \\
\text { deltatus-O. costatus Zone) }\end{array}$ & Ol & Ol \\
\hline 03JT21 & Teller C-5 & 65 & 32.43 & 167 & 22.57 & $\begin{array}{l}\text { Early Ordovician (Macerodus dianae or A. deltatus- } \\
\text { O. costatus Zone) }\end{array}$ & Ol? & $\begin{array}{l}\text { p€I, pOal } \\
(69 b)\end{array}$ \\
\hline 93BK37A & Teller C-5 & 65 & 32.43 & 167 & 22.93 & $\begin{array}{l}\text { Early, but not earliest, Ordovician ("Low Diversity } \\
\text { Interval" to Reutterodus andinus Zone) }\end{array}$ & Ol & $\mathrm{Ol}$ \\
\hline 93BK37C & Teller C-5 & 65 & 32.44 & 167 & 22.61 & $\begin{array}{l}\text { Early Ordovician; most likely "Low Diversity Inter- } \\
\text { val" to Macerodus dianae Zone }\end{array}$ & Ol & Ol \\
\hline 93BK15 & Teller C-5 & 65 & 32.59 & 167 & 18.14 & $\begin{array}{l}\text { middle Early Ordovician ("Low Diversity Interval" } \\
\text { to Macerodus dianae Zone) }\end{array}$ & Ol & $\mathrm{Ol}$ \\
\hline 93BK17 & Teller C-5 & 65 & 32.64 & 167 & 18.06 & $\begin{array}{l}\text { middle Early Ordovician ("Low Diversity Interval" } \\
\text { to Macerodus dianae Zone) }\end{array}$ & Ol & Ol \\
\hline 93BK51 & Teller C-5 & 65 & 32.65 & 167 & 18.57 & Cambrian-Middle Devonian & OPI & $\begin{array}{l}\text { p€I, pOul } \\
(69 b)\end{array}$ \\
\hline 93BK29 & Teller C-5 & 65 & 32.74 & 167 & 19.42 & $\begin{array}{l}\text { middle Early Ordovician ("Low Diversity Interval" } \\
\text { to Macerodus dianae Zone) }\end{array}$ & Ol & Ol \\
\hline 93BK20 & Teller C-5 & 65 & 32.77 & 167 & 18.03 & $\begin{array}{l}\text { early to middle Middle Ordovician (Histiodella holo- } \\
\text { dentata Zone to Cahabagnathus sweeti Zone) }\end{array}$ & Ols & Odl (69b) \\
\hline 03JT03 & Teller C-5 & 65 & 32.8 & 167 & 9.82 & probably Middle-Late Ordovician & OPI & $\begin{array}{l}\mathrm{p} \in \mathrm{l}, \mathrm{pOal} \\
(69 \mathrm{~b})\end{array}$ \\
\hline $7-1-85 B$ & Teller C-5 & 65 & 32.81 & 167 & 18.13 & Middle Ordovician & Ols & Olsh (69b) \\
\hline $7-1-85 A$ & Teller C-5 & 65 & 32.81 & 167 & 18.1 & Middle Ordovician (late Arenig-early Caradoc) & Ols & Odl (69b) \\
\hline $7-1-85 \mathrm{D}, \mathrm{C}$ & Teller C-5 & 65 & 32.8 & 167 & 18.5 & $\begin{array}{l}\text { middle Early Ordovician ("Low Diversity Interval" } \\
\text { to Acodus deltatus-Oneotodus costatus Zone) }\end{array}$ & Ol & Ol \\
\hline 93BK50 & Teller C-5 & 65 & 32.87 & 167 & 18.8 & $\begin{array}{l}\text { middle Early Ordovician ("Low Diversity Interval" } \\
\text { to Macerodus dianae Zone) }\end{array}$ & Ol & Ol \\
\hline $7-1-85 \mathrm{~F}$ & Teller C-5 & 65 & 33.3 & 167 & 17.8 & Ordovician-Devonian & Ol? & $\begin{array}{l}\text { p€l, pOul } \\
(69 \mathrm{~b})\end{array}$ \\
\hline $5726-1$ & Teller C-5 & 65 & 35 & 167 & 15 & early Middle Ordovician? & [Ols] & - \\
\hline AS-52 & Teller C-6 & 65 & 31.18 & 167 & 31.25 & Cambrian-Triassic & ORt & $p € s$ \\
\hline AS-22-TC & Teller C-6 & 65 & 31.96 & 167 & 43.53 & Cambrian-Triassic & OPt & $p € s$ \\
\hline 05AD34G & Nome C-1 & 64 & 35.17 & 165 & 23.35 & late Permian-Triassic (likely Triassic) & Dcs & - \\
\hline 06AD5A & Nome C-1 & 64 & 35.24 & 165 & 23.12 & Silurian(?)-Triassic & Dcs & - \\
\hline 83ADn75 & Kotzebue A-2 & 66 & 2.3 & 162 & 37.2 & Silurian-Middle Devonian & DObm & DObm \\
\hline $7-18-84 \mathrm{~A}$ & Kotzebue A-2 & 66 & 5.4 & 162 & 48.22 & Ordovician-early late Silurian (early Ludlow) & DObm & DObm \\
\hline
\end{tabular}


determined. For example, the Middle/UpperOrdovician boundary has been revised downward considerably(see, for example, Webbyand others, 2004). reference (if published) or provided by collector. For Bendeleben, Candle, Kotzebue, Norton Bay, and Solomon quadrangles, source map units refer map unit of Sainsbury (1969b). Unit in bracket (for example, [Ols]) indicates outcrop too small to show on map, or other issue explained in remarks ID, conodont fauna identifier; N.D., not determined; USGS no., number under which collection is filed in USGS repository. Localities are plotted

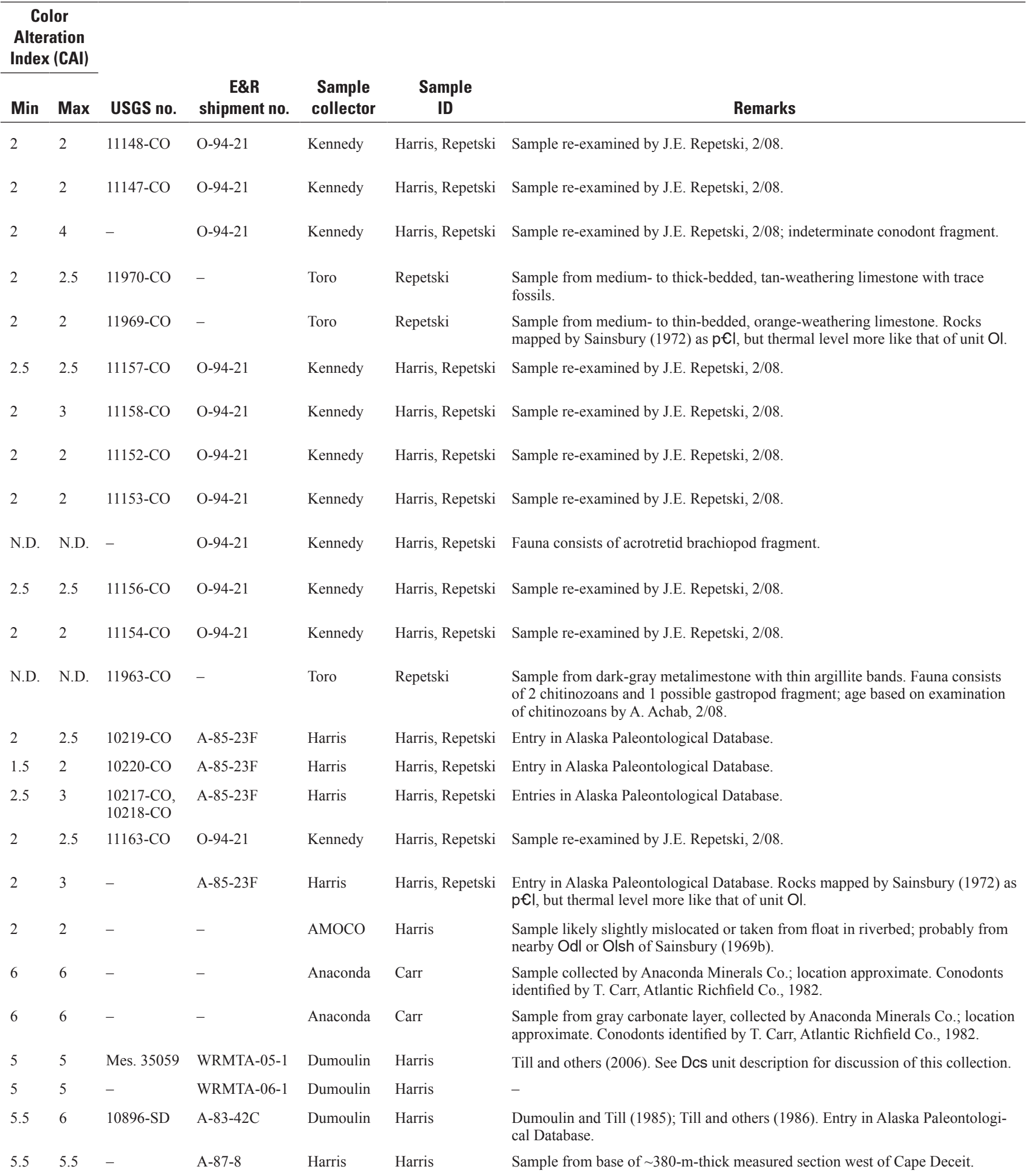


Table A-1. Conodont data from the Seward Peninsula._Continued (table spans facing page)

[Ages listed have not been revised to reflect all changes in stratigraphic terminology that have occurred since the ages given here were Ordovician conodont zonation, Series, and Stage usage herein follows that given in Harris and others (1995). Geologic unit (source map) from cited to map units of Till and others (1986). For Teller quadrangle, source map units refer to map units of Sainsbury (1972) if unspecified; (69b) indicates a column. Alaska Paleontological Database found online at http://www.alaskafossil.org. E\&R, Examination and Report by USGS paleontologist; on sheet 2; see table A-2 for temperature ranges for CAl values]

\begin{tabular}{|c|c|c|c|c|c|c|c|c|}
\hline \multirow[b]{2}{*}{ Field no. } & \multirow[b]{2}{*}{ Quadrangle } & \multicolumn{2}{|c|}{ Lat (N) } & \multicolumn{2}{|c|}{ Long (W) } & \multirow[b]{2}{*}{ Age } & \multicolumn{2}{|c|}{ Geologic unit } \\
\hline & & Deg & Min & Deg & Min & & (This map) & $\begin{array}{c}\text { (Source } \\
\text { map) }\end{array}$ \\
\hline $7-18-84 \mathrm{C}$ & Kotzebue A-2 & 66 & 5.39 & 162 & 48.28 & $\begin{array}{l}\text { middle-early late Silurian (early Wenlock-early } \\
\text { Ludlow) }\end{array}$ & DObm & DObm \\
\hline 7-18-84D, E & Kotzebue A-2 & 66 & 5.37 & 162 & 48.34 & $\begin{array}{l}\text { middle-early late Silurian (early Wenlock-early } \\
\text { Ludlow) }\end{array}$ & DObm & DObm \\
\hline $7-18-84 \mathrm{~F}$ & Kotzebue A-2 & 66 & 5.3 & 162 & 48.7 & $\begin{array}{l}\text { middle-early late Silurian (latest Wenlock-early } \\
\text { Ludlow) }\end{array}$ & DObm & DObm \\
\hline $7-18-84 \mathrm{G}$ & Kotzebue A-2 & 66 & 5.26 & 162 & 48.9 & $\begin{array}{l}\text { middle-early late Silurian (latest Wenlock-early } \\
\text { Ludlow) }\end{array}$ & DObm & DObm \\
\hline 7-18-84H, I, J, and K & Kotzebue A-2 & 66 & 5.24 & 162 & 49 & $\begin{array}{l}\text { middle-early late Silurian (latest Wenlock-early } \\
\text { Ludlow) }\end{array}$ & DObm & DObm \\
\hline $7-18-84 \mathrm{~L}$ & Kotzebue A-2 & 66 & 5.24 & 162 & 49 & $\begin{array}{l}\text { early late Silurian (early Ludlow; Ozarkodina crassa } \\
\text { Zone) }\end{array}$ & DObm & DObm \\
\hline $7-18-84 \mathrm{M}$ & Kotzebue A-2 & 66 & 5.2 & 162 & 49.2 & early late Silurian (early Ludlow) & DObm & DObm \\
\hline 7-18-84O, P & Kotzebue A-2 & 66 & 5.17 & 162 & 49.4 & $\begin{array}{l}\text { early late Silurian (early Ludlow; upper Ozarkodina } \\
\text { crassa through Ancoradella ploeckensis Zone) }\end{array}$ & DObm & DObm \\
\hline $7-18-84 Q$ & Kotzebue A-2 & 66 & 5.13 & 162 & 49.7 & $\begin{array}{l}\text { early late Silurian (latest early to early middle } \\
\text { Ludlow; Ancoradella ploeckensis Zone) }\end{array}$ & DObm & DObm \\
\hline 83ADn44 & Kotzebue A-2 & 66 & 5.37 & 162 & 48.37 & middle middle Silurian (middle Wenlock) & DObm & DObm \\
\hline 83ADn74 & Kotzebue A-2 & 66 & 5.89 & 162 & 45.36 & Ordovician-Devonian & $\mathrm{Pzd}$ & $\mathrm{Pzd}$ \\
\hline 84ADn79C & Kotzebue A-3 & 66 & 3.9 & 163 & 12.3 & $\begin{array}{l}\text { middle-early late Silurian (possibly early-middle } \\
\text { Wenlock) }\end{array}$ & DObm & DObm \\
\hline 82ADu45 & $\begin{array}{l}\text { Bendeleben } \\
\text { A-1 }\end{array}$ & 65 & 1 & 162 & 1 & middle-early late Silurian (Wenlock-Ludlow) & TKs & TKc \\
\hline $83 \mathrm{ADn} 27$ & $\begin{array}{l}\text { Bendeleben } \\
\text { A-1 }\end{array}$ & 65 & 2.1 & 162 & 5.51 & middle-late Silurian (Wenlock-middle Pridoli) & Sd & Sd \\
\hline 84ADn54 & $\begin{array}{l}\text { Bendeleben } \\
\text { A-1 }\end{array}$ & 65 & 3 & 162 & 10.25 & $\begin{array}{l}\text { middle Early Ordovician ("Low Diversity Interval" } \\
\text { to Macerodus dianae Zone) }\end{array}$ & Od & Od \\
\hline 83ADn34O & $\begin{array}{l}\text { Bendeleben } \\
\text { A-1 }\end{array}$ & 65 & 4 & 162 & 1 & Middle Devonian & TKs & TKc \\
\hline 83ADn34H & $\begin{array}{l}\text { Bendeleben } \\
\text { A-1 }\end{array}$ & 65 & 4 & 162 & 1 & middle-early late Silurian (Wenlock-Ludlow) & TKs & TKc \\
\hline 83ADn34I & $\begin{array}{l}\text { Bendeleben } \\
\text { A-1 }\end{array}$ & 65 & 4 & 162 & 1 & late Early Devonian (late Emsian) & TKs & TKc \\
\hline 83ADn34M & $\begin{array}{l}\text { Bendeleben } \\
\text { A-1 }\end{array}$ & 65 & 4 & 162 & 1 & late Early-Middle Devonian & TKs & TKc \\
\hline 83ADn34L & $\begin{array}{l}\text { Bendeleben } \\
\text { A-1 }\end{array}$ & 65 & 4 & 162 & 1 & middle-early late Silurian (Wenlock-Ludlow) & TKs & TKc \\
\hline $83 \mathrm{ACl} 196$ & $\begin{array}{l}\text { Bendeleben } \\
\text { A-1 }\end{array}$ & 65 & 5 & 162 & 7.1 & late Early Devonian (earliest Emsian) & Ddm & Ddm \\
\hline $83 \mathrm{ACl} 94$ & $\begin{array}{l}\text { Bendeleben } \\
\text { A-1 }\end{array}$ & 65 & 5 & 162 & 8 & $\begin{array}{l}\text { middle to late Early Ordovician ("Low Diversity } \\
\text { Interval" to Reutterodus andinus Zone) }\end{array}$ & Od & Od \\
\hline 84ADn57B & $\begin{array}{l}\text { Bendeleben } \\
\text { A-1 }\end{array}$ & 65 & 5.9 & 162 & 8.1 & $\begin{array}{l}\text { middle Early Ordovician-Devonian (probably } \\
\text { Ordovician) }\end{array}$ & Od & Od \\
\hline
\end{tabular}


determined. For example, the Middle/UpperOrdovician boundary has been revised downward considerably(see, for example, Webbyand others, 2004). reference (if published) or provided by collector. For Bendeleben, Candle, Kotzebue, Norton Bay, and Solomon quadrangles, source map units refer map unit of Sainsbury (1969b). Unit in bracket (for example, [Ols]) indicates outcrop too small to show on map, or other issue explained in remarks ID, conodont fauna identifier; N.D., not determined; USGS no., number under which collection is filed in USGS repository. Localities are plotted

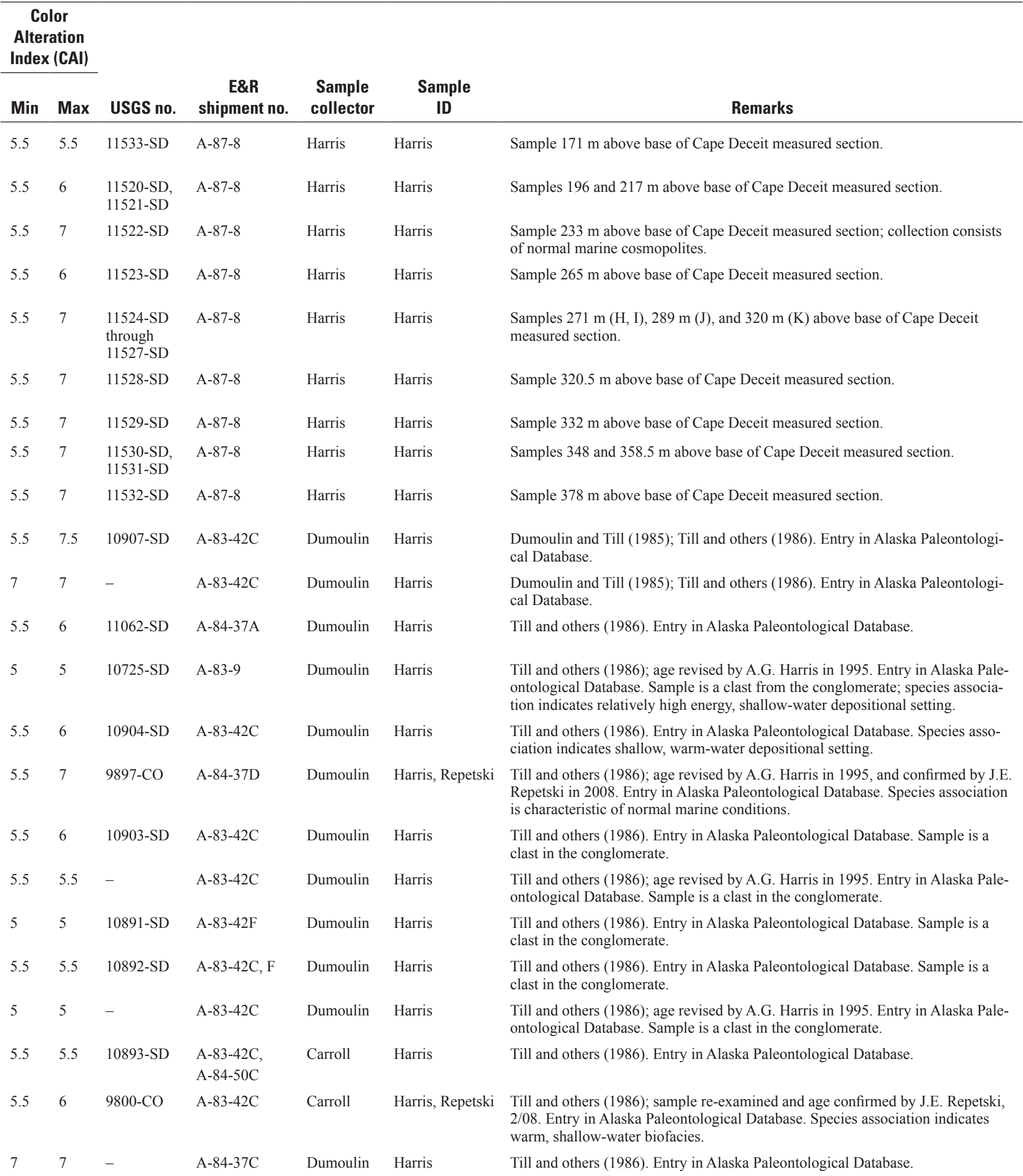


Table A-1. Conodont data from the Seward Peninsula._Continued (table spans facing page)

[Ages listed have not been revised to reflect all changes in stratigraphic terminology that have occurred since the ages given here were Ordovician conodont zonation, Series, and Stage usage herein follows that given in Harris and others (1995). Geologic unit (source map) from cited to map units of Till and others (1986). For Teller quadrangle, source map units refer to map units of Sainsbury (1972) if unspecified; (69b) indicates a column. Alaska Paleontological Database found online at http://www.alaskafossil.org. E\&R, Examination and Report by USGS paleontologist; on sheet 2; see table A-2 for temperature ranges for CAl values]

\begin{tabular}{|c|c|c|c|c|c|c|c|c|}
\hline \multirow[b]{2}{*}{ Field no. } & \multirow[b]{2}{*}{ Quadrangle } & \multicolumn{2}{|c|}{ Lat (N) } & \multicolumn{2}{|c|}{ Long (W) } & \multirow[b]{2}{*}{ Age } & \multicolumn{2}{|c|}{ Geologic unit } \\
\hline & & Deg & Min & Deg & Min & & (This map) & $\begin{array}{c}\text { (Source } \\
\text { map) }\end{array}$ \\
\hline 82ADu53 & $\begin{array}{l}\text { Bendeleben } \\
\text { A-1 }\end{array}$ & 65 & 9.33 & 162 & 10.07 & $\begin{array}{l}\text { middle Early Devonian (middle Siegenian)-Middle } \\
\text { Devonian }\end{array}$ & $\mathrm{Ddm}$ & $\mathrm{Ddm}$ \\
\hline 82ADu57 & $\begin{array}{l}\text { Bendeleben } \\
\text { A-1 }\end{array}$ & 65 & 9.04 & 162 & 7.98 & Middle Ordovician-Middle Devonian & Ddm & $\mathrm{Ddm}$ \\
\hline 83ADn61 & $\begin{array}{l}\text { Bendeleben } \\
\text { B-1 }\end{array}$ & 65 & 15.5 & 162 & 17.7 & Middle Devonian & $\mathrm{Ddm}$ & $\mathrm{Ddm}$ \\
\hline 83ADn88 & $\begin{array}{l}\text { Bendeleben } \\
\text { B-1 }\end{array}$ & 65 & 16.4 & 162 & 15.3 & Ordovician-Devonian & Ddm & $\mathrm{Ddm}$ \\
\hline 84ATi88B & $\begin{array}{l}\text { Bendeleben } \\
\text { B-1 }\end{array}$ & 65 & 26.58 & 162 & 3.7 & Middle Ordovician-Middle Devonian & $\mathrm{Pzd}$ & $\mathrm{Pzd}$ \\
\hline 83АТi227 & $\begin{array}{l}\text { Bendeleben } \\
\text { B-1 }\end{array}$ & 65 & 26.7 & 162 & 3.94 & Early Mississippian & $P_{z d}$ & $\mathrm{Pzd}$ \\
\hline 82ADu78RR & $\begin{array}{l}\text { Bendeleben } \\
\mathrm{C}-2\end{array}$ & 65 & 30.5 & 162 & 41.1 & Silurian-Devonian & TKs & TKc \\
\hline 82ADu78II & $\begin{array}{l}\text { Bendeleben } \\
\text { C-2 }\end{array}$ & 65 & 30.5 & 162 & 41.1 & middle-early late Silurian (Wenlock-Ludlow) & TKs & TKc \\
\hline 82ADu78JJ & $\begin{array}{l}\text { Bendeleben } \\
\text { C-2 }\end{array}$ & 65 & 30.5 & 162 & 41.1 & early-middle Silurian & TKs & TKc \\
\hline 82ADu78DD & $\begin{array}{l}\text { Bendeleben } \\
\text { C-2 }\end{array}$ & 65 & 30.5 & 162 & 41.1 & middle-early late Silurian (Wenlock-Ludlow) & TKs & TKc \\
\hline 82ADu78MM & $\begin{array}{l}\text { Bendeleben } \\
\text { C-2 }\end{array}$ & 65 & 30.5 & 162 & 41.1 & Middle-Late Ordovician & TKs & TKc \\
\hline 82ATi197B & $\begin{array}{l}\text { Bendeleben } \\
\text { C-5 }\end{array}$ & 65 & 35 & 164 & 25.88 & Ordovician-Permian (most probably Ordovician) & [Od] & Od \\
\hline 84AKn151 & $\begin{array}{l}\text { Bendeleben } \\
\text { C-5 }\end{array}$ & 65 & 39.92 & 164 & 20.33 & Phanerozoic & DOx & $O € x$ \\
\hline 82ATi195B & $\begin{array}{l}\text { Bendeleben } \\
\text { C-6 }\end{array}$ & 65 & 32.01 & 164 & 36.68 & $\begin{array}{l}\text { Middle Devonian-earliest Mississippian (Kinder- } \\
\text { hookian) }\end{array}$ & Ddm & $\mathrm{Ddm}$ \\
\hline 82ADu68 & $\begin{array}{l}\text { Bendeleben } \\
\text { C-6 }\end{array}$ & 65 & 37 & 164 & 33 & $\begin{array}{l}\text { Middle Ordovician-Middle Devonian; when com- } \\
\text { bined with megafossil data from this locality, age is } \\
\text { restricted to Middle Devonian }\end{array}$ & $\mathrm{Pzm}$ & $\mathrm{Pzm}$ \\
\hline 82ADu69 & $\begin{array}{l}\text { Bendeleben } \\
\text { D-2 }\end{array}$ & 65 & 46 & 162 & 46 & $\begin{array}{l}\text { middle Early Ordovician ("Low Diversity Interval" } \\
\text { to Macerodus dianae Zone) }\end{array}$ & Od & Od \\
\hline 82ADu73 & $\begin{array}{l}\text { Bendeleben } \\
\text { D-2 }\end{array}$ & 65 & 47.58 & 162 & 44.93 & late Early Devonian (early Emsian) & Ddm & Ddm \\
\hline 82ADu71 & $\begin{array}{l}\text { Bendeleben } \\
\text { D-2 }\end{array}$ & 65 & 48.09 & 162 & 46.02 & early to middle Middle Ordovician & Od & Od \\
\hline $83 \mathrm{ACl113B}$ & $\begin{array}{l}\text { Bendeleben } \\
\text { D-2 }\end{array}$ & 65 & 52.7 & 162 & 35 & $\begin{array}{l}\text { Early/Middle Devonian boundary (latest Emsian- } \\
\text { earliest Eifelian) }\end{array}$ & $\mathrm{Ddm}$ & Ddm \\
\hline 83ADn85 & $\begin{array}{l}\text { Bendeleben } \\
\text { D-2 }\end{array}$ & 65 & 53.6 & 162 & 35.7 & late Early Devonian (Emsian)-Middle Devonian & $\mathrm{Ddm}$ & $\mathrm{Ddm}$ \\
\hline $83 \mathrm{ACl114}$ & $\begin{array}{l}\text { Bendeleben } \\
\text { D-2 }\end{array}$ & 65 & 53.83 & 162 & 39.17 & $\begin{array}{l}\text { middle to late Early Ordovician (Macerodus dianae } \\
\text { Zone to Oepikodus communis Zone) }\end{array}$ & Od & Od \\
\hline 82ADu76 & $\begin{array}{l}\text { Bendeleben } \\
\text { D-2 }\end{array}$ & 65 & 54 & 162 & 35 & late Early Devonian (early Emsian) & Ddm & $\mathrm{Ddm}$ \\
\hline
\end{tabular}


determined. For example, the Middle/UpperOrdovician boundary has been revised downward considerably(see, for example, Webbyand others, 2004). reference (if published) or provided by collector. For Bendeleben, Candle, Kotzebue, Norton Bay, and Solomon quadrangles, source map units refer map unit of Sainsbury (1969b). Unit in bracket (for example, [Ols]) indicates outcrop too small to show on map, or other issue explained in remarks ID, conodont fauna identifier; N.D., not determined; USGS no., number under which collection is filed in USGS repository. Localities are plotted

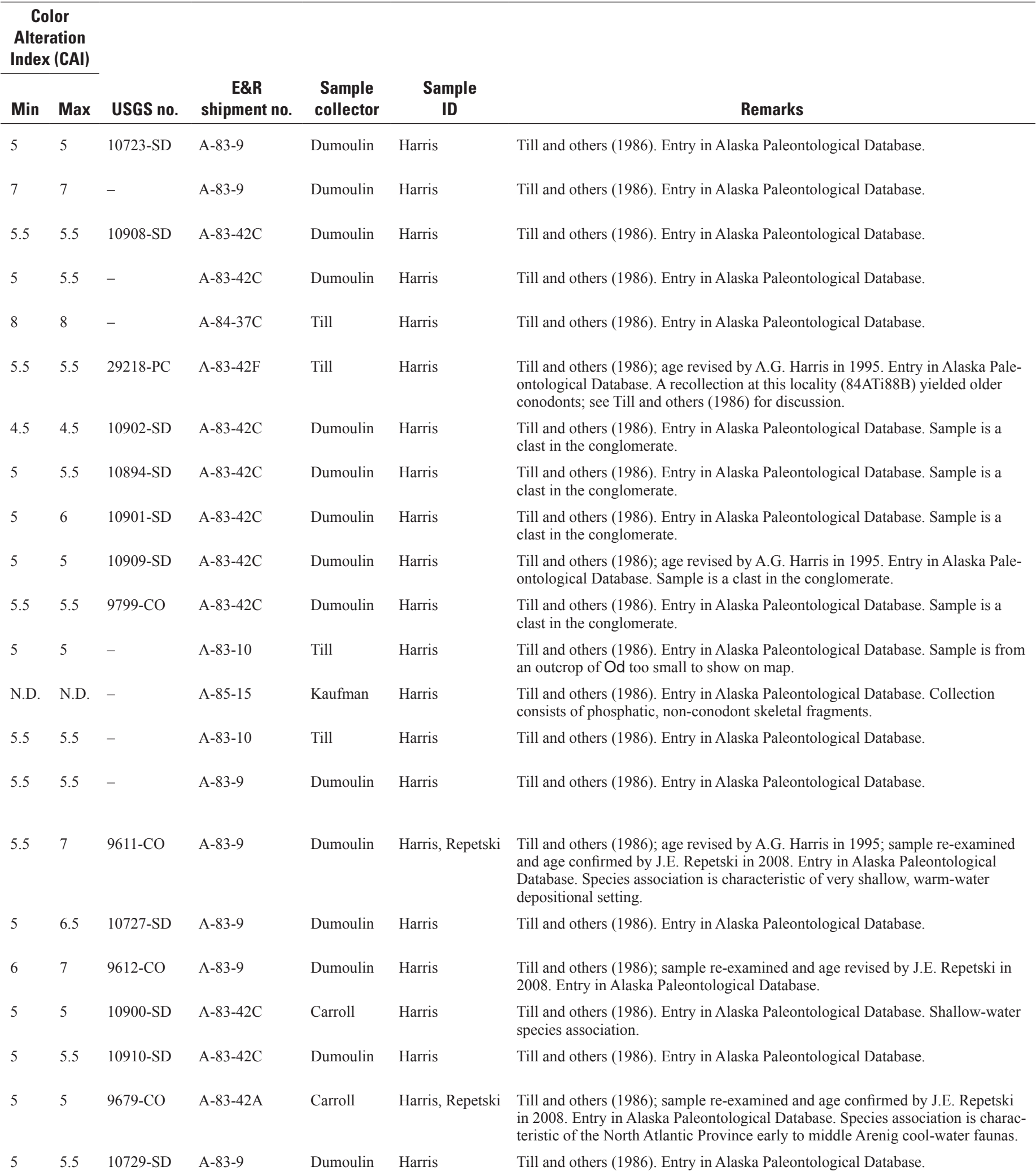


Table A-1. Conodont data from the Seward Peninsula._Continued (table spans facing page)

[Ages listed have not been revised to reflect all changes in stratigraphic terminology that have occurred since the ages given here were Ordovician conodont zonation, Series, and Stage usage herein follows that given in Harris and others (1995). Geologic unit (source map) from cited to map units of Till and others (1986). For Teller quadrangle, source map units refer to map units of Sainsbury (1972) if unspecified; (69b) indicates a column. Alaska Paleontological Database found online at http://www.alaskafossil.org. E\&R, Examination and Report by USGS paleontologist; on sheet 2; see table A-2 for temperature ranges for CAl values]

\begin{tabular}{|c|c|c|c|c|c|c|c|c|}
\hline \multirow[b]{2}{*}{ Field no. } & \multirow[b]{2}{*}{ Quadrangle } & \multicolumn{2}{|c|}{ Lat (N) } & \multicolumn{2}{|c|}{ Long (W) } & \multirow[b]{2}{*}{ Age } & \multicolumn{2}{|c|}{ Geologic unit } \\
\hline & & Deg & Min & Deg & Min & & (This map) & $\begin{array}{c}\text { (Source } \\
\text { map) }\end{array}$ \\
\hline 82ADu75 & $\begin{array}{l}\text { Bendeleben } \\
\text { D-2 }\end{array}$ & 65 & 54.74 & 162 & 35.5 & late Early Devonian (early Emsian)-Middle Devonian & Ddm & Ddm \\
\hline 82ADu74 & $\begin{array}{l}\text { Bendeleben } \\
\mathrm{D}-2\end{array}$ & 65 & 55.66 & 162 & 35.41 & Middle Ordovician-Middle Devonian & Ddm & Ddm \\
\hline 84ATi224 & $\begin{array}{l}\text { Bendeleben } \\
\text { D-5 }\end{array}$ & 65 & 46 & 164 & 11 & Middle Ordovician-Middle Devonian & Od & Od \\
\hline $84 \mathrm{ADn} 80 \mathrm{~A}$ & $\begin{array}{l}\text { Bendeleben } \\
\text { D-5 }\end{array}$ & 65 & 47 & 164 & 10 & $\begin{array}{l}\text { early to middle Middle Ordovician (Histiodella holo- } \\
\text { dentata Zone to lower Amorphognathus tvaerensis } \\
\text { Zone; possibly H. holodentata Zone to Cahabagna- } \\
\text { thus sweeti Zone) }\end{array}$ & Od & Od \\
\hline 82ADu63 & $\begin{array}{l}\text { Bendeleben } \\
\text { D-5 }\end{array}$ & 65 & 50.37 & 164 & 22.59 & probable middle Early to Middle Devonian & Ddm & Ddm \\
\hline 84ATi15Y & Solomon C-1 & 64 & 33.5 & 162 & 27.33 & Ordovician-Triassic & DEbm & D€bm \\
\hline 84ATi15Z & Solomon C-1 & 64 & 33.5 & 162 & 27.33 & $\begin{array}{l}\text { middle Early Ordovician (middle Arenig)-Late } \\
\text { Ordovician }\end{array}$ & DEbm & D€bm \\
\hline 84ADn5H & Solomon C-1 & 64 & 34.6 & 162 & 24 & middle-early late Silurian (Wenlock-Ludlow) & DEbm & D€bm \\
\hline 84ATi8AA & Solomon C-1 & 64 & 34.87 & 162 & 22.5 & late Early-latest Middle Devonian (Emsian-Givetian) & Ddm & Ddm \\
\hline 84ATi8AB & Solomon C-1 & 64 & 34.92 & 162 & 22.5 & late Early Devonian (Emsian) & Ddm & $\mathrm{Ddm}$ \\
\hline 84ADn10A & Solomon C-1 & 64 & 37 & 162 & 17 & middle-early late Silurian (Wenlock-early Ludlow) & {$[\mathrm{Sd}]$} & $\mathrm{Pzd}$ \\
\hline 84ATi23 & Solomon C-1 & 64 & 37.45 & 162 & 13.8 & middle Early Devonian (Siegenian) & DEbm & Debm \\
\hline 84ADn2A & Solomon C-1 & 64 & 38 & 162 & 14 & Middle Devonian & Ddm & $\mathrm{Ddm}$ \\
\hline 84ATi57 & Solomon C-1 & 64 & 38.6 & 162 & 22.4 & Early through possibly early Middle Cambrian & D€bm & Debm \\
\hline 84ADn3A & Solomon C-1 & 64 & 39 & 162 & 13 & Middle Devonian & Ddm & Ddm \\
\hline 84ADn3B & Solomon C-1 & 64 & 39 & 162 & 13 & Middle Devonian & Ddm & $\mathrm{Ddm}$ \\
\hline 84ADn16 & Solomon C-1 & 64 & 39.9 & 162 & 23.5 & Middle Devonian & Ddm & Ddm \\
\hline $84 \mathrm{ADn} 31$ & Solomon C-1 & 64 & 44.5 & 162 & 18.3 & late Silurian-Early Devonian & DEbm & Debm \\
\hline 82ADu59 & Solomon C-3 & 64 & 44.73 & 163 & 27.66 & middle to late Early Devonian & Ddm & Ddm \\
\hline $83 \mathrm{ADn} 2$ & Solomon C-4 & 64 & 34.04 & 163 & 41.27 & Phanerozoic & Ddm & Ddm \\
\hline $84 \mathrm{AGe} 133$ & Solomon C-5 & 64 & 44.72 & 164 & 25.7 & Ordovician-Middle Devonian & DOx & $O \in x$ \\
\hline 83ADn25 & Solomon D-1 & 64 & 49.51 & 162 & 17.51 & middle Silurian-most of Middle Devonian & Ddm & Ddm \\
\hline 82ADu17 & Solomon D-1 & 64 & 50.9 & 162 & 13.68 & $\begin{array}{l}\text { Silurian-Middle Devonian; when combined with } \\
\text { megafossil data from this locality, age is restricted to } \\
\text { Middle Devonian }\end{array}$ & Ddm & Ddm \\
\hline 84ATi112 & Solomon D-1 & 64 & 52.9 & 162 & 9.9 & Middle Devonian & Ddm & Ddm \\
\hline 83SK28A & Solomon D-1 & 64 & 53.18 & 162 & 11.13 & latest Early-earliest Middle Devonian & Ddm & Ddm \\
\hline
\end{tabular}


determined. For example, the Middle/UpperOrdovician boundary has been revised downward considerably(see, for example, Webbyand others, 2004). reference (if published) or provided by collector. For Bendeleben, Candle, Kotzebue, Norton Bay, and Solomon quadrangles, source map units refer map unit of Sainsbury (1969b). Unit in bracket (for example, [Ols]) indicates outcrop too small to show on map, or other issue explained in remarks ID, conodont fauna identifier; N.D., not determined; USGS no., number under which collection is filed in USGS repository. Localities are plotted

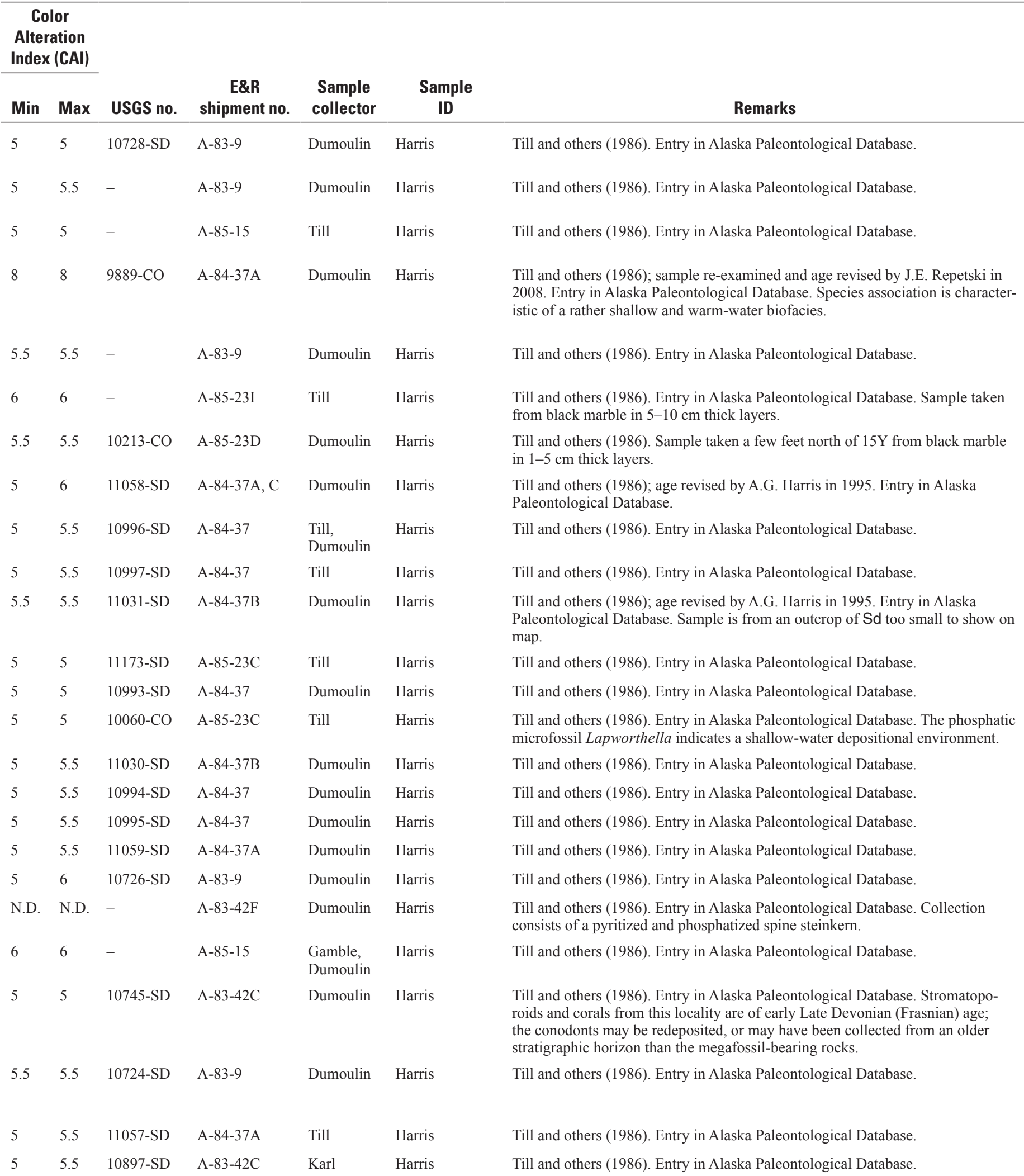


Table A-1. Conodont data from the Seward Peninsula._Continued (table spans facing page)

[Ages listed have not been revised to reflect all changes in stratigraphic terminology that have occurred since the ages given here were Ordovician conodont zonation, Series, and Stage usage herein follows that given in Harris and others (1995). Geologic unit (source map) from cited to map units of Till and others (1986). For Teller quadrangle, source map units refer to map units of Sainsbury (1972) if unspecified; (69b) indicates a column. Alaska Paleontological Database found online at http://www.alaskafossil.org. E\&R, Examination and Report by USGS paleontologist; on sheet 2; see table A-2 for temperature ranges for CAl values]

\begin{tabular}{|c|c|c|c|c|c|c|c|c|}
\hline \multirow[b]{2}{*}{ Field no. } & \multirow[b]{2}{*}{ Quadrangle } & \multicolumn{2}{|c|}{ Lat (N) } & \multicolumn{2}{|c|}{ Long (W) } & \multirow[b]{2}{*}{ Age } & \multicolumn{2}{|c|}{ Geologic unit } \\
\hline & & Deg & Min & Deg & Min & & (This map) & $\begin{array}{l}\text { (Source } \\
\text { map) }\end{array}$ \\
\hline 83SK31A & Solomon D-1 & 64 & 57.93 & 162 & 9.04 & late Early Devonian (middle Siegenian-Emsian) & Ddm & Ddm \\
\hline 84ADn52B & Solomon D-1 & 64 & 59.5 & 162 & 3.7 & late Early-Middle Devonian & TKs & TKc \\
\hline $84 \mathrm{ADn} 52 \mathrm{C}$ & Solomon D-1 & 64 & 59.5 & 162 & 3.7 & Middle Devonian & TKs & TKc \\
\hline 83ADn5 & Solomon D-3 & 64 & 45.24 & 163 & 28.66 & $\begin{array}{l}\text { latest Early-earliest Late Devonian; when com- } \\
\text { bined with megafossil data from this locality, age is } \\
\text { restricted to Middle Devonian-earliest Late Devonian }\end{array}$ & Ddm & Ddm \\
\hline 84ADn75Z & Solomon D-5 & 64 & 48 & 164 & 12.5 & Ordovician & DOx & o€x \\
\hline 83ADn32 & Solomon D-5 & 64 & 54.38 & 164 & 28 & middle Silurian-Early Devonian & {$\left[\mathrm{Pz}_{\mathbf{z}} \mathrm{d}\right]$} & $\mathrm{Pzd}$ \\
\hline 84ADn108D & Solomon D-5 & 64 & 54.93 & 164 & 29.58 & Early through possibly early Middle Cambrian & $€ d$ & $€ d$ \\
\hline $82 \mathrm{ACl} 91$ & Solomon D-5 & 64 & 55.2 & 164 & 14.6 & $\begin{array}{l}\text { Ordovician-Devonian (probably Early-Middle } \\
\text { Ordovician) }\end{array}$ & $\mathrm{P}_{2 \mathrm{~m}}$ & $\mathrm{Pzm}$ \\
\hline 83ADn29B & Solomon D-5 & 64 & 56 & 164 & 18 & late Silurian-Devonian & {$[\mathrm{Pzm}]$} & $\mathrm{Pzm}$ \\
\hline 83ADn29A & Solomon D-5 & 64 & 55.77 & 164 & 18.29 & $\begin{array}{l}\text { Early Ordovician (Rossodus manitouensis Zone to } \\
\text { "Low Diversity Interval") }\end{array}$ & Od & Od \\
\hline $82 \mathrm{ACl} 94$ & Solomon D-5 & 64 & 57.5 & 164 & 26.2 & $\begin{array}{l}\text { middle Early to earliest Middle Ordovician (most } \\
\text { likely "Low Diversity Interval" to Histiodella sinu- } \\
\text { osa Zone) }\end{array}$ & Od & Od \\
\hline 84ATi281 & Solomon D-6 & 64 & 49.58 & 164 & 55.33 & Early (but not earliest) through Middle Ordovician & Oim & Oim \\
\hline 85APa106 & Candle A-5 & 65 & 1.8 & 161 & 23.2 & $\begin{array}{l}\text { Middle Ordovician-Middle Devonian (possibly } \\
\text { Ordovician) }\end{array}$ & $\mathrm{Pzd}$ & \\
\hline $85 \mathrm{APa} 120$ & Candle A-6 & 65 & 0.2 & 161 & 50.5 & $\begin{array}{l}\text { Includes faunal elements of two ages: Early Ordovi- } \\
\text { cian (Rossodus manitouensis Zone to Macerodus } \\
\text { dianae Zone) and Early (Emsian)-Middle Devonian }\end{array}$ & Pzd & \\
\hline 84ADn42 & Candle B-6 & 65 & 27 & 161 & 58.7 & Ordovician-Triassic & $\mathrm{Pzd}$ & $\mathrm{Pzd}$ \\
\hline $85 \mathrm{ADn} 2 \mathrm{~B}$ & $\begin{array}{l}\text { Norton Bay } \\
\text { C-6 }\end{array}$ & 64 & 44.43 & 161 & 32.3 & middle-early late Silurian (Wenlock-Ludlow) & D€bm & D€bm \\
\hline $85 \mathrm{ADn} 3 \mathrm{~A}$ & $\begin{array}{l}\text { Norton Bay } \\
\text { C-6 }\end{array}$ & 64 & 44.8 & 161 & 31.21 & late Silurian-Middle Devonian & {$[\mathrm{Ddm}]$} & Ddm \\
\hline 85ATi1A & $\begin{array}{l}\text { Norton Bay } \\
\text { D-5 }\end{array}$ & 64 & 48.8 & 161 & 20.9 & late Early Devonian-Early Mississippian & {$[\mathrm{Ddm}]$} & Ddm \\
\hline 85APa101 & $\begin{array}{l}\text { Norton Bay } \\
\text { D-6 }\end{array}$ & 64 & 53.4 & 161 & 31.9 & Silurian-Triassic & $\mathrm{Pzd}$ & $P_{z} d$ \\
\hline $84 \mathrm{ADn} 51 \mathrm{~K}$ & $\begin{array}{l}\text { Norton Bay } \\
\text { D-6 }\end{array}$ & 64 & 54.6 & 161 & 57.9 & Ordovician-Permian & TKs & TKc \\
\hline $84 \mathrm{ADn} 51 \mathrm{M}$ & $\begin{array}{l}\text { Norton Bay } \\
\text { D-6 }\end{array}$ & 64 & 54.6 & 161 & 57.9 & late Silurian-Devonian & TKs & TKc \\
\hline $84 \mathrm{ADn} 51 \mathrm{~N}$ & $\begin{array}{l}\text { Norton Bay } \\
\text { D-6 }\end{array}$ & 64 & 54.6 & 161 & 57.9 & Middle Ordovician-Middle Devonian & TKs & TKc \\
\hline 84ADn51O & $\begin{array}{l}\text { Norton Bay } \\
\text { D-6 }\end{array}$ & 64 & 54.6 & 161 & 57.9 & Middle Ordovician-Middle Devonian & TKs & TKc \\
\hline
\end{tabular}


determined. For example, the Middle/UpperOrdovician boundary has been revised downward considerably(see, for example, Webbyand others, 2004). reference (if published) or provided by collector. For Bendeleben, Candle, Kotzebue, Norton Bay, and Solomon quadrangles, source map units refer map unit of Sainsbury (1969b). Unit in bracket (for example, [Ols]) indicates outcrop too small to show on map, or other issue explained in remarks ID, conodont fauna identifier; N.D., not determined; USGS no., number under which collection is filed in USGS repository. Localities are plotted

\begin{tabular}{|c|c|c|c|c|c|c|}
\hline \multicolumn{2}{|c|}{$\begin{array}{c}\text { Color } \\
\text { Alteration } \\
\text { Index (CAI) }\end{array}$} & \multirow[b]{2}{*}{ USGS no. } & \multirow[b]{2}{*}{$\begin{array}{l}\text { E\&R } \\
\text { shipment no. }\end{array}$} & \multirow[b]{2}{*}{$\begin{array}{l}\text { Sample } \\
\text { collector }\end{array}$} & \multirow[b]{2}{*}{$\begin{array}{l}\text { Sample } \\
\text { ID }\end{array}$} & \multirow[b]{2}{*}{ Remarks } \\
\hline Min & Max & & & & & \\
\hline 5 & 5.5 & 10898-SD & A- $83-42 C$ & Karl & Harris & Till and others (1986). Entry in Alaska Paleontological Database. \\
\hline 5.5 & 5.5 & 11060-SD & A-84-37A & Dumoulin & Harris & $\begin{array}{l}\text { Till and others (1986). Entry in Alaska Paleontological Database. Sample is a } \\
\text { clast in the conglomerate. }\end{array}$ \\
\hline 5.5 & 6 & 11061-SD & A-84-37A & Dumoulin & Harris & $\begin{array}{l}\text { Till and others (1986). Entry in Alaska Paleontological Database. Sample is a } \\
\text { clast in the conglomerate. }\end{array}$ \\
\hline 5.5 & 5.5 & 10895-SD & A- $83-42 C$ & Dumoulin & Harris & Till and others (1986). Entry in Alaska Paleontological Database. \\
\hline 5.5 & 6 & $10059-\mathrm{CO}$ & A- $85-23 C$ & Dumoulin & Harris & Till and others (1986). Entry in Alaska Paleontological Database. \\
\hline 5 & 5 & 10906-SD & A-83-42C & Dumoulin & Harris & $\begin{array}{l}\text { Till and others (1986). Entry in Alaska Paleontological Database. Sample is from } \\
\text { an outcrop of Pzd too small to show on map. }\end{array}$ \\
\hline N.D. & N.D. & $9937-\mathrm{CO}$ & A- $85-15$ & Dumoulin & Harris & $\begin{array}{l}\text { Till and others (1986). Entry in Alaska Paleontological Database. Collection } \\
\text { consists of the phosphatic microfossil Lapworthella, which indicates a shallow- } \\
\text { water depositional setting. }\end{array}$ \\
\hline 5 & 6 & - & A-83-9 & Carroll & Harris & Till and others (1986). Entry in Alaska Paleontological Database. \\
\hline 5.5 & 6.5 & 10905-SD & A- $83-42 C$ & Dumoulin & Harris & $\begin{array}{l}\text { Till and others (1986). Entry in Alaska Paleontological Database. Sample is from } \\
\text { an outcrop of Pzm too small to show on map. }\end{array}$ \\
\hline 4 & 4 & $9801-\mathrm{CO}$ & A- $83-42 C$ & Dumoulin & Harris & $\begin{array}{l}\text { Till and others (1986); age revised by J.E. Repetski, 2/08. Entry in Alaska } \\
\text { Paleontological Database. The CAI of this collection is lower than values from } \\
\text { other collections in the Nome Complex. The collection may represent laboratory } \\
\text { contamination, or a remnant of a structurally higher thrust sheet. Species associa- } \\
\text { tion indicates a warm, shallow-water depositional setting. }\end{array}$ \\
\hline 5.5 & 5.5 & $9610-\mathrm{CO}$ & A-83-9 & Carroll & Harris & $\begin{array}{l}\text { Till and others (1986); sample re-examined and age confirmed by J.E. Repetski, } \\
\text { 2/08. Entry in Alaska Paleontological Database. }\end{array}$ \\
\hline 7 & 7 & $9938-\mathrm{CO}$ & A- $85-15$ & Till & Harris & Till and others (1986). Entry in Alaska Paleontological Database. \\
\hline$\sim 5.0$ & $\sim 5.0$ & - & A-86-16 & $\begin{array}{l}\text { Patton, } \\
\text { Dumoulin }\end{array}$ & Denkler & Entry in Alaska Paleontological Database. \\
\hline 6 & 6 & - & A-85-23D & $\begin{array}{l}\text { Patton, } \\
\text { Dumoulin }\end{array}$ & Harris & $\begin{array}{l}\text { Collection may have sampled two rock types of different age, or older conodonts } \\
\text { may have been reworked into a younger rock. }\end{array}$ \\
\hline 5 & 5 & - & A-84-37C & Dumoulin & Harris & Till and others (1986). Entry in Alaska Paleontological Database. \\
\hline 5.5 & 6 & 11229-SD & A-85-23D & Dumoulin & Harris & Till and others (1986); age revised by A.G. Harris in 1995. \\
\hline 5 & 5 & 11230-SD & A-85-23D & Dumoulin & Harris & Sample is from an outcrop of Ddm too small to show on map. \\
\hline$\sim 5.0$ & $\sim 5.0$ & - & A-86-16 & Till & Denkler & $\begin{array}{l}\text { Entry in Alaska Paleontological Database. Sample is from an outcrop of Ddm } \\
\text { too small to show on map. }\end{array}$ \\
\hline 5 & 5 & - & A-86-16 & $\begin{array}{l}\text { Patton, } \\
\text { Dumoulin }\end{array}$ & Denkler & Entry in Alaska Paleontological Database. \\
\hline 5.5 & 6 & - & A- $85-15$ & Dumoulin & Harris & $\begin{array}{l}\text { Till and others (1986). Entry in Alaska Paleontological Database. Sample is a } \\
\text { clast in the conglomerate. }\end{array}$ \\
\hline 5.5 & 5.5 & 11134-SD & A- $85-15$ & Dumoulin & Harris & $\begin{array}{l}\text { Till and others (1986). Entry in Alaska Paleontological Database. Sample is a } \\
\text { clast in the conglomerate. }\end{array}$ \\
\hline 5 & 5.5 & - & A-84-37B & Dumoulin & Harris & $\begin{array}{l}\text { Till and others (1986). Entry in Alaska Paleontological Database. Sample is a } \\
\text { clast in the conglomerate. }\end{array}$ \\
\hline 5 & 5.5 & - & A-84-37A & Dumoulin & Harris & $\begin{array}{l}\text { Till and others (1986). Entry in Alaska Paleontological Database. Sample is a } \\
\text { clast in the conglomerate. }\end{array}$ \\
\hline
\end{tabular}


Table A-1. Conodont data from the Seward Peninsula.-Continued (table spans facing page)

[Ages listed have not been revised to reflect all changes in stratigraphic terminology that have occurred since the ages given here were Ordovician conodont zonation, Series, and Stage usage herein follows that given in Harris and others (1995). Geologic unit (source map) from cited to map units of Till and others (1986). For Teller quadrangle, source map units refer to map units of Sainsbury (1972) if unspecified; (69b) indicates a column. Alaska Paleontological Database found online at http://www.alaskafossil.org. E\&R, Examination and Report by USGS paleontologist; on sheet 2; see table A-2 for temperature ranges for CAI values]

\begin{tabular}{|c|c|c|c|c|c|c|c|c|}
\hline \multirow[b]{2}{*}{ Field no. } & \multirow[b]{2}{*}{ Quadrangle } & \multicolumn{2}{|c|}{ Lat (N) } & \multicolumn{2}{|c|}{ Long (W) } & \multirow[b]{2}{*}{ Age } & \multicolumn{2}{|c|}{ Geologic unit } \\
\hline & & Deg & Min & Deg & Min & & (This map) & $\begin{array}{c}\text { (Source } \\
\text { map) }\end{array}$ \\
\hline $85 \mathrm{APa} 104$ & $\begin{array}{l}\text { Norton Bay } \\
\text { D-6 }\end{array}$ & 64 & 57.97 & 161 & 37.12 & $\begin{array}{l}\text { Early Ordovician ("Low Diversity Interval" to } \\
\text { Reutterodus andinus Zone) }\end{array}$ & {$[\mathrm{Od}]$} & Od \\
\hline 83ADn92B & $\begin{array}{l}\text { Norton Bay } \\
\text { D-6 }\end{array}$ & 64 & 58 & 161 & 57.5 & middle-early late Silurian (Wenlock-Ludlow) & TKs & TKc \\
\hline 83ADn92CC & $\begin{array}{l}\text { Norton Bay } \\
\text { D-6 }\end{array}$ & 64 & 58 & 161 & 57.5 & Middle Ordovician-Middle Devonian & TKs & TKc \\
\hline 83ADn92AA & $\begin{array}{l}\text { Norton Bay } \\
\text { D-6 }\end{array}$ & 64 & 58 & 161 & 57.5 & Middle Ordovician-Middle Devonian & TKs & TKc \\
\hline 83ADn92BB & $\begin{array}{l}\text { Norton Bay } \\
\text { D-6 }\end{array}$ & 64 & 58 & 161 & 57.5 & $\begin{array}{l}\text { Silurian-Permian; probably middle Silurian-late } \\
\text { Early Devonian (early Emsian) }\end{array}$ & TKs & TKc \\
\hline
\end{tabular}


determined. For example, the Middle/UpperOrdovician boundary has been revised downward considerably(see, for example, Webby and others, 2004). reference (if published) or provided by collector. For Bendeleben, Candle, Kotzebue, Norton Bay, and Solomon quadrangles, source map units refer map unit of Sainsbury (1969b). Unit in bracket (for example, [Ols]) indicates outcrop too small to show on map, or other issue explained in remarks ID, conodont fauna identifier; N.D., not determined; USGS no., number under which collection is filed in USGS repository. Localities are plotted

\begin{tabular}{|c|c|c|c|c|c|c|}
\hline \multicolumn{2}{|c|}{$\begin{array}{c}\text { Color } \\
\text { Alteration } \\
\text { Index (CAI) }\end{array}$} & \multirow[b]{2}{*}{ USGS no. } & \multirow[b]{2}{*}{$\begin{array}{c}\text { E\&R } \\
\text { shipment no. }\end{array}$} & \multirow[b]{2}{*}{$\begin{array}{l}\text { Sample } \\
\text { collector }\end{array}$} & \multirow[b]{2}{*}{$\begin{array}{l}\text { Sample } \\
\text { ID }\end{array}$} & \multirow[b]{2}{*}{ Remarks } \\
\hline Min & Max & & & & & \\
\hline$\sim 5.0$ & $\sim 5.0$ & $10312-\mathrm{CO}$ & A-86-16 & $\begin{array}{l}\text { Patton, } \\
\text { Dumoulin }\end{array}$ & Denkler & $\begin{array}{l}\text { Entry in Alaska Paleontological Database. Sample is from an outcrop of Od too } \\
\text { small to show on map. }\end{array}$ \\
\hline 5 & 5.5 & 10836-SD & A-83-42B & Dumoulin & Harris & $\begin{array}{l}\text { Till and others (1986); age revised by A.G. Harris in 1995. Entry in Alaska Pale- } \\
\text { ontological Database. Sample is a clast in the conglomerate; species association } \\
\text { indicates relatively high energy, shallow-water depositional setting. }\end{array}$ \\
\hline 5 & 5.5 & - & A-84-37A & Dumoulin & Harris & $\begin{array}{l}\text { Till and others (1986). Entry in Alaska Paleontological Database. Sample is a } \\
\text { clast in the conglomerate. }\end{array}$ \\
\hline 5 & 5.5 & - & A-85-15 & Dumoulin & Harris & $\begin{array}{l}\text { Till and others (1986). Entry in Alaska Paleontological Database. Sample is a } \\
\text { clast in the conglomerate. }\end{array}$ \\
\hline 6 & 7 & - & A-85-15 & Dumoulin & Harris & $\begin{array}{l}\text { Till and others (1986). Entry in Alaska Paleontological Database. Sample is a } \\
\text { clast in the conglomerate. }\end{array}$ \\
\hline
\end{tabular}

Table A-2. Temperature ranges for Color Alteration Indices (CAls) of conodonts.

[Taken from Epstein and others (1977), Rejebian and others (1987), and Watts and others (1994). Temperature ranges for conodonts from an Arrhenius plot of experimental data. For CAl values $\leq 5.5$, ranges represent heating durations of 500 m.y. to 1 m.y. (lower temperature is 500 m.y.-value); for values $\geq 6$, ranges cover durations of 500 m.y to 1,000 years]

\begin{tabular}{cc}
\hline Minimum CAI & Temperature $\left({ }^{\circ} \mathbf{C}\right)$ \\
\hline 1 & $<50-80$ \\
1.5 & $50-90$ \\
2 & $60-140$ \\
2.5 & $100-150$ \\
3 & $120-190$ \\
3.5 & $150-200$ \\
4 & $190-250$ \\
4.5 & $250-300$ \\
5 & $300-480$ \\
5.5 & $>360$ \\
6 & $360-550$ \\
6.5 & $440-610$ \\
7 & $490-720$ \\
8 & $>600$ \\
\hline
\end{tabular}

